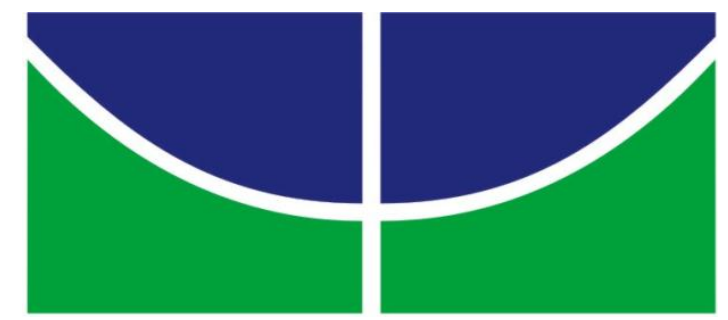

Universidade de Brasília

Instituto de Ciências Biológicas

Departamento de Botânica

Aprimoramento da embriogênese somática de dendezeiro (Elaeis guineensis Jacq.), a partir de folhas de plantas adultas: Influência do genótipo e caracterização morfoanatômica e bioquímica

Aluna: Patrícia Monah Cunha Bartos

Orientador: Jonny Everson Scherwinski-Pereira

Brasília - DF

Dezembro/2016 
Aprimoramento da embriogênese somática de dendezeiro (Elaeis guineensis Jacq.), a partir de folhas de plantas adultas: Influência do genótipo e caracterização morfoanatômica e bioquímica

Tese apresentada ao Departamento de Botânica, do Instituto de Ciências Biológicas da Universidade de Brasília, como parte dos requisitos necessários à obtenção do título de Doutorado em Botânica.

Aluna: Patrícia Monah Cunha Bartos

Orientador: Jonny Everson Scherwinski-Pereira

$$
\text { Brasília - DF }
$$

Dezembro/2016 
Ficha catalográfica elaborada automaticamente, com os dados fornecidos pelo(a) autor(a)

BB293a

Bartos, Patrícia Monah Cunha Aprimoramento da embriogênese somática de dendezeiro (Elaeis guineensis Jacq.), a partir de folhas de plantas adultas: Influência do genótipo e caracterização morfoanatômica e bioquímica / Patrícia Monah Cunha Bartos; orientador Jonny Everson Scherwinski-Pereira. -- Brasilia, 2016. $151 \mathrm{p}$.

Tese (Doutorado - Doutorado em Botânica) -Universidade de Brasília, 2016.

1. Arecaceae. 2. Micropropagação. 3. Histologia. 4. Fisiologia. 5. Cultura de Tecidos. I. Scherwinski Pereira, Jonny Everson, orient. II. Título. 


\section{Aprimoramento da embriogênese somática de dendezeiro \\ (Elaeis guineensis Jacq.), a partir de folhas de plantas adultas: \\ Influência do genótipo e caracterização morfoanatômica e bioquímica}

Patrícia Monah Cunha Bartos

"Esta tese foi julgada adequada para a obtenção do Título de Doutor e aprovada em sua forma final pelo Programa de Pós-Graduação em Botânica"

Banca Examinadora:

Jonny Everson Scherwinski-Pereira

Doutor em Agronomia

Presidente da Banca

Conceição Eneida dos Santos Silveira

Doutora em Biologia e Fisiologia

Vegetais

Membro titular

Thomas Christopher Rhys Williams

Doutor em Plant Sciences

Membro titular
Regina Beatriz Bernd

Doutora em Ciências Biológicas

Membro suplente 
Este trabalho é dedicado a todos os meus familiares e pessoas intimamente ligadas à minha vida, que no período de desenvolvimento deste, me apoiaram com amor, paciência, carinho e compreensão, demonstrando que a superação nos momentos difíceis vale a pena, por estarmos ao lado de quem realmente se importa com o meu sucesso. Por tudo o que aprendi, por todas as conversas agradáveis, pelas horas que tive o privilégio de trabalhar com essas pessoas tão maravilhosas, sou eternamente grata...

À Professora Dra. Lourdes Isabel Velho do Amaral (in memoriam);

À Deus;

Aos meus pais, Paulo Roberto e Maria das Graças;

Aos meus pais de coração, Reinaldo e Sandra; Aos meus irmãos, Paulo Roberto e Milena Cunha; E ao meu amado, Hugo. 
"Onde não puderes amar não te demores."

Frida Khalo 


\section{Agradecimentos}

No decorrer destes últimos 4 anos contei com o apoio e a amizade de pessoas e instituições, cujos nomes gostaria de destacar:

Hugo Teixeira Gomes, por ser essa pessoa tão maravilhosa, esse companheiro mais do que especial que Deus colocou na minha vida. Por todo apoio e compreensão nas horas mais difíceis e principalmente pelo seu amor.

Paulo Roberto Bartos, pai, herói e amigo, agradeço pelas palavras certas, nas horas certas e pelo amor incondicional.

Maria das Graças, exemplo de mulher, mãe, agradeço por sua dedicação e carinho e por ser a minha melhor amiga.

Reinaldo, um grande exemplo de superação em minha vida.

Sandra, pelo exemplo de caráter e honestidade.

Paulo Roberto Cunha Bartos, pelo exemplo de coragem, garra e determinação.

Milena Cunha, pelo amor, carinho e atenção.

Beatriz de Castro e Moacir Cunha, pelas orientações de sempre seguir no caminho do bem.

Carlos, Vanice, Carolina, Alice, Sara, Rafael, pela amizade, amor, carinho e paciência durante toda a minha vida e especialmente nessa fase tão importante para mim.

Robson e família, pelo exemplo de união e amor.

Rogério e família, pessoas que tanto admiro.

Aurora Bartos, pelo exemplo de fé.

Pavleska Bartos, exemplo de determinação, pela sua capacidade de valorização mesmo quando nem tudo está bome principalmente pela sua sincera amizade.

Jesus e família, por me acolherem com tanto carinho em sua casa.

Aurora e família, pessoas que moram no meu coração.

Stella e família, pessoas tão especiais e importantes em minha vida.

Mestre Francisco, por me apresentar de forma tão carinhosa e sublime o caminho da luz e por guiar esses meus passos, às vezes tão errantes. 
Mestre Raimundo Irineu Serra, por ser esse grande mestre da vida, por estar sempre comigo, por nutrir em minha alma a boa conduta e a boa direção.

Andrea, Adriano e família, laços feitos de amor.

Maria Alice Campos Freire, por ter aberto o meu coração para o caminho da floresta.

Raquel, Lila, Júlia, Thalita, Ester, Cris, Stéphanie, Ana Luiza, amigas muito especiais de caminhada rumo ao autoconhecimento.

Isabela Matos, por ser essa pessoa que chegou na minha vida de uma forma tão doce e especial que chegou para ficar.

Ana Paula Goveia, pela amizade e sinceridade de longa data. Por ser uma pessoa em minha vida que mesmo longe sempre está perto.

Raissa Guimarães Leite, amiga do coração, mulher formadora de opinião.

Renata Cristina, pela sua capacidade, força e por ter se tornado uma grande amiga durante essa caminhada do mestrado e do doutorado.

Juliane Laner de Toledo, pela sua forma amorosa de ser.

Janiffe, pela alegria de viver.

Marta, pela sua coragem.

Dr. João BatistaTeixeira, pela oportunidade de realização deste trabalho, pela orientação e por tantas informações e ensinamentos a mim confiados, além de ser, para mim, esse grande mestre da vida e da pesquisa.

Dra. Lourdes Isabel Velho do Amaral, agradeço em memória pela sua amizade e pela sua herança de valores, que contribuíram e contribuem para a minha realização pessoal e profissional.

Dr. Thomas Christopher Rhys Williams, por ser esse grande pesquisador, exemplo de caráter, de profissional além de ser para mim um amigo muito especial que ganhei na caminhada do doutorado. Agradeço de coração pelas orientações, pela paciência, pela direção nos momentos mais difíceis desse trabalho.

Dra. Cristiane da Silva Ferreira e Dr. Augusto César Franco, pela orientação durante a pesquisa e pela permissão em utilizar as instalações do Laboratório da Fisiologia Vegetal da Universidade de Brasília.

Luciana Florencio de Lacerda, por ser essa amiga maravilhosa de longa data.

Andre Luís Xavier de Souza, por sua ajuda no trabalho do dia-dia, sua atenção, amizade e carinho, seu exemplo de ética, coerência e seriedade. 
Fábio Nakamura Noda, grande companheiro de trabalho no laboratório, agradeço pelas conversas e pelo estudo da química analítica.

Inésio Marinho, pelas inúmeras conversas recheadas de conhecimento.

Professora Andrea Maranhão, Professora Graça, Professora Cynthia, Professor José Raimundo, Nilma, Rodrigo, Cristina, por me acolher com tanto carinho e aconchego na Coordenação de Graduação de Biologia, por serem pessoas que mesmo em pouco tempo já são tão especiais pra mim.

Carlos Vinícius, Elínea Oliveira, Tatiane Monteiro, pelo apoio e convívio diário no Laboratório de Cultura de Tecidos II.

Funcionários da Embrapa Recursos Genéticos e Biotecnologia, que, de uma forma ou de outra, colaboraram com a infraestrutura necessária.

Capes, pela concessão da bolsa.

Universidade de Brasília -Unb, por tanto conhecimento adquirido.

Departamento de Botânica da Unb, pelo apoio.

A todos, porque seria impossível nomeá-los sem esquecer alguém, pelo sorriso, pela força, pelas críticas, importantes apoios que me permitiram vencer mais esta etapa. 


\section{ÍNDICE DE ASSUNTOS}

ÍNDICES DE ASSUNTOS ……………………....................................... i

ÍNDICE DE TABELAS …............................................................................ iv

ÍNDICE DE FIGURAS …............................................................. v

SÍMBOLOS E ABREVIATURAS ………………..................................

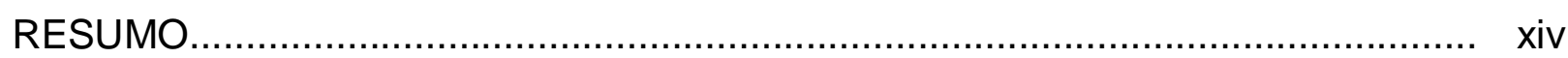

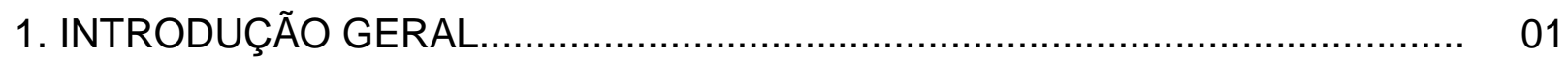

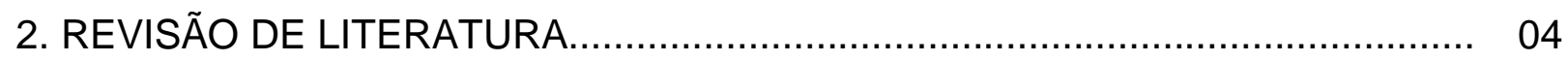

2.1. Aspectos gerais do dendezeiro (Elaeis guineensis Jacq.)....................... 04

2.2. Cultura de Tecidos de Plantas............................................................ 08

2.3. Embriogênese somática.................................................................... 11

2.4. Estudos anatômicos....................................................................... 16

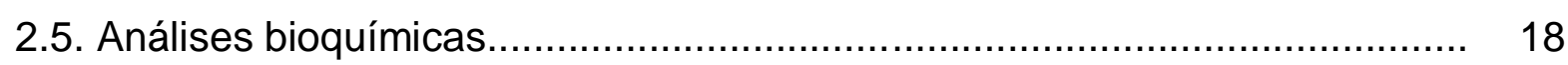

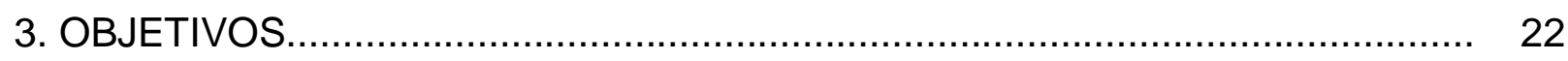

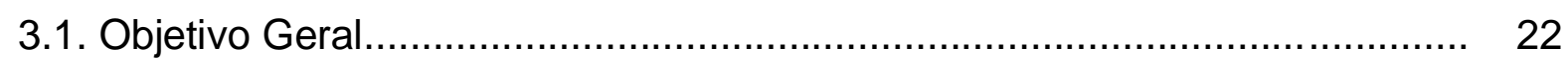

3.2. Objetivos Específicos.......................................................................... 22

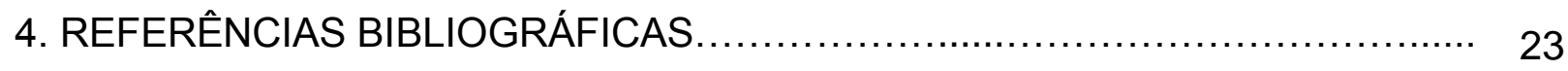

\section{CAPÍTULO 1 \\ OTIMIZAÇÃO DAS ETAPAS DE INDUÇÃO E MULTIPLICAÇÃO DE CALOS DA EMBRIOGÊNESE SOMÁTICA DE FOLHAS IMATURAS DE DENDEZEIRO (Elaeis guineensis Jacq.)}

RESUMO.

1.

INTRODUÇÃO 38

2. MATERIAL E MÉTODOS......................................................................... 40

2.1. Local de realização do experimento....................................................... 40

2.2. Obtenção do material vegetal......................................................... 40

2.3. Preparo de explantes e indução de calos primários e embriogênicos........ 40

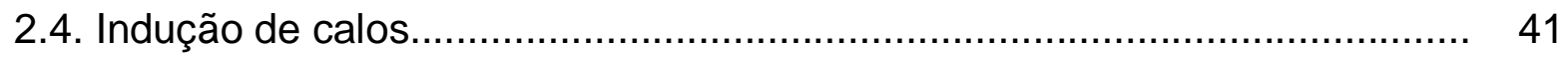

2.4.1. Efeito dos diferentes tipos e concentrações de auxinas........................... 41 
2.4.2. Efeito do genótipo e da posição da folha.

2.5. Multiplicação de calos primários e calos embriogênicos........................... $\quad 45$

2.6. Diferenciação e maturação de embriões somáticos................................... 47

2.7. Regeneração dos embriões somáticos................................................... 47

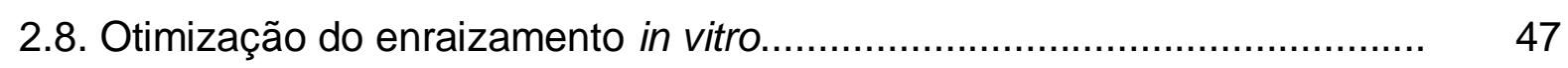

2.9. Aclimatização das mudas..................................................................... 48

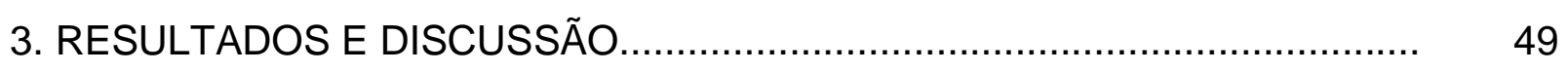

3.1. Indução de calos........................................................................... 49

3.1.1. Efeito dos diferentes tipos e concentrações de auxinas......................... 49

3.1.2. Efeito do genótipo e da posição da folha............................................ 54

3.2. Multiplicação de calos.................................................................... 60

3.3. Diferenciação, regeneração, enraizamento/alongamento e 63 aclimatização.

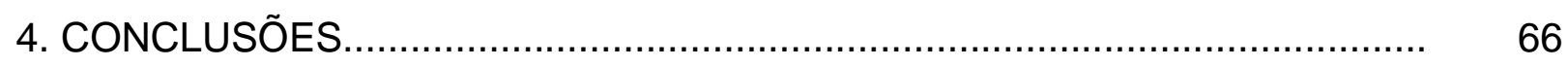

5. REFERÊNCIAS BIBLIOGRÁFICAS...................................................... 67

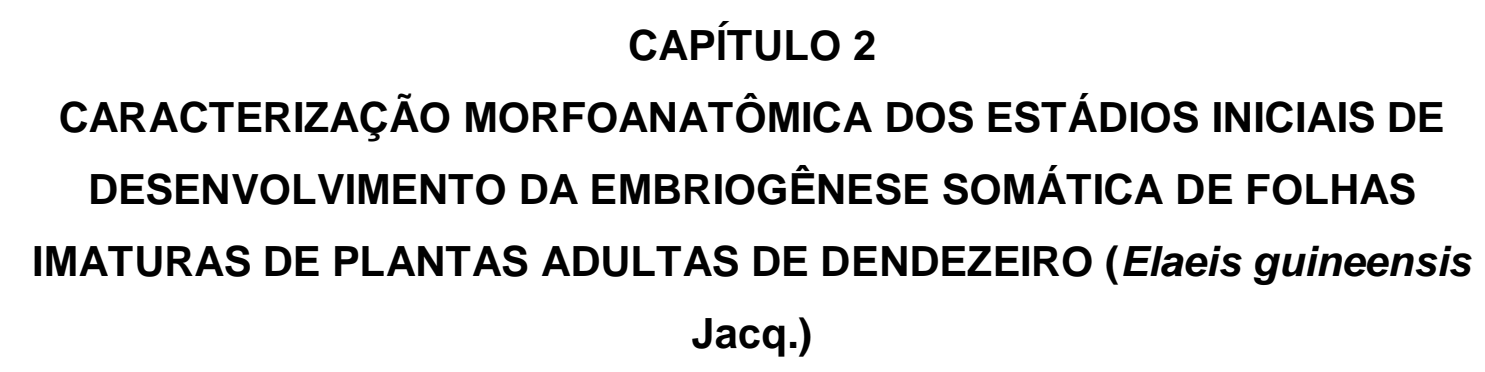

RESUMO. 76

1.

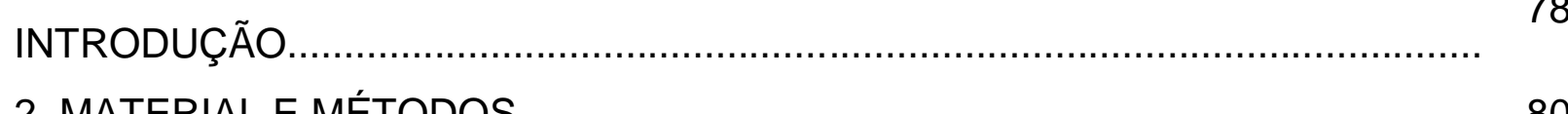

2.1. Local de realização do experimento........................................................ 80

2.2. Obtenção do material vegetal............................................................... 80

2.3. Estudos morfoanatômicos dos estágios de desenvolvimento...................... 81

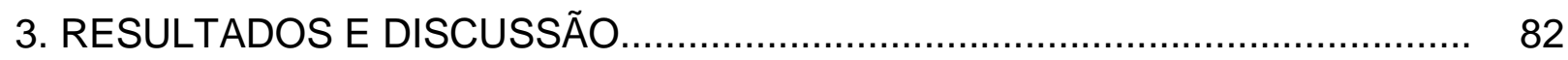

3.1. Estudos morfoanatômicos dos estágios de desenvolvimento..................... 82

4. CONCLUSÕES..................................................................................... 100

5. REFERÊNCIAS BIBLIOGRÁFICAS........................................................ 101 


\section{CAPÍTULO 3}

\section{CARACTERIZAÇÃO BIOQUÍMICA DOS ESTÁGIOS INICIAIS DE DESENVOLVIMENTO DA EMBRIOGÊNESE SOMÁTICA DE FOLHAS \\ IMATURAS DE PLANTAS ADULTAS DE DENDEZEIRO (Elaeis guineensis Jacq.)}

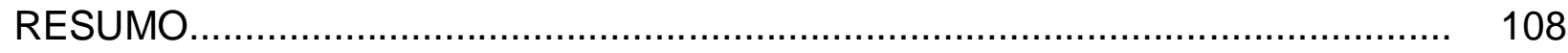

1. INTRODUÇÃO................................................................................... 110

2. MATERIAL E MÉTODOS........................................................................ 112

2.1. Local de realização do experimento.......................................................... 112

2.2. Obtenção do material vegetal............................................................. 112

2.3. Caracterização bioquímica dos estádios de desenvolvimento.................... 113

2.3.1. Açúcares solúveis......................................................................... 114

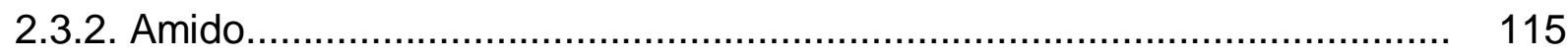

2.3.3. Ácidos graxos (ésteres metílicos de ácidos graxos).............................. 116

2.3.4. Aminoácidos livres...................................................................... 116

2.3.5. Proteínas Totais.............................................................................. 117

2.3.6. Análise do Perfil Metabólico............................................................... 118

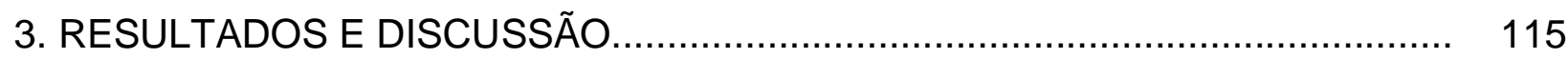

3.1. Açúcares solúveis............................................................................ 120

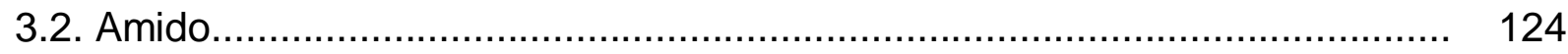

3.3. Ácidos graxos (ésteres metílicos de ácidos graxos)................................. 127

3.4. Aminoácidos livres.......................................................................... 133

3.5. Proteínas Totais............................................................................... 137

3.6. Análise do Perfil Metabólico .................................................................. 139

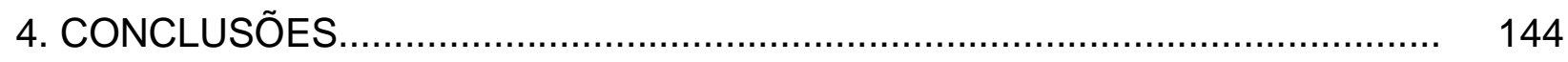

5. REFERÊNCIAS BIBLIOGRÁFICAS....................................................... 145 


\section{ÍNDICE DE TABELAS}

\section{CAPITULO 1}

Tabela 1. Efeito dos diferentes tipos (ANA, 2,4-D e Picloram) e concentrações $(0,225,450,675$ e $900 \mu \mathrm{M})$ de auxinas nas médias referentes à formação de calo primário e oxidação de explantes foliares de dendezeiro (Elaeis guineensis Jacq.), variedade B35-17-29 aos 180 dias de cultivo.

Tabela 2. Influência do genótipo (B35-29-32, B35-29-33, B35-17-33, B35-17-29, A25-15-11 e A25-14-28) e da posição da folha (apical e basal) nas médias referentes à percentagem de formação de calo primário e percentagem de oxidação na indução de calos de dendezeiro (Elaeis guineensis Jacq.), após 180 dias de cultivo

Tabela 3. Influência do tipo de calo (calo primário ou embriogênico) e consistência do meio de cultivo (meio líquido ou sólido) no ganho de biomassa fresca (\%) durante a multiplicação de calos de dendezeiro (Elaeis guineensis Jacq.) obtidos de folhas imaturas.

\section{CAPÍTULO 3}

Tabela 1. Teores dos ácidos graxos que constituem os lipídios nos estádios de desenvolvimento obtidos durante a indução da embriogênese somática de folhas imaturas de plantas adultas dendezeiro (Elaeis guineensis Jacq.). 


\section{ÍNDICE DE FIGURAS}

\section{REVISÃO DE LITERATURA}

Figura 1. Fases da coleta (A-C) e preparo (D-F) para a desinfestação do palmito de dendezeiro (Elaeis guineensis Jacq.). A. Retirada das folhas adultas. B. Corte do estipe com motosserra. C. Separação do palmito cerca de $20 \mathrm{~cm}$ acima do meristema apical da planta. D e E. Isolamento das folhas imaturas. F. Folhas imaturas em processo de desinfestação.

\section{CAPÍTULO 1}

Figura 1. Fases da coleta $(A-C)$ e preparo (D-F) para a desinfestação do palmito de dendezeiro (Elaeis guineensis Jacq.). A. Retirada das folhas adultas. B. Corte do estipe com motosserra. C. Separação do palmito. D e E. Isolamento das folhas imaturas. F. Folhas imaturas em processo de desinfestação.

Figura 2. Formação de calos primários induzidos a partir de folhas imaturas de dendezeiro (Elaeis guineensis Jacq.). A. Explante sem formação de calo, ao zero dias de cultivo. B. Calo tipo 1 aos 180 dias de cultivo. C. Calo tipo 3 aos 180 dias de cultivo. D. Calo tipo 5 aos 180 dias de cultivo. Barras: A-D. 2,0 $\mathrm{mm}$

Figura 3. Oxidação de explantes foliares de dendezeiro (Elaeis guineensis Jacq.). A. Explante não oxidado, ao zero dias de cultivo. B. Oxidação tipo 1 aos 180 dias de cultivo. C. Oxidação tipo 3 aos 180 dias de cultivo. D. Oxidação tipo 5 aos 180 dias de cultivo. Barras: A-B. 2,0 $\mathrm{mm}$

Figura 4. Aspecto do material utilizado como explante inicial para a indução de calos no cultivo in vitro de dendezeiro (Elaeis guineensis Jacq.)

Figura 5. Caracterização morfológica de calos embriogênicos $(A)$ formados em meio de indução, contendo $225 \mu \mathrm{m}$ de Picloram e raízes (B) formadas em meio de indução, contendo $900 \mu \mathrm{m}$ de ANA. Indução realizada a partir da inoculação 
de folhas jovens de dendezeiro (Elaeis guineensis Jacq.). Barras: A. 2 mm, B. $5,0 \mathrm{~cm}$

Figura 6. Multiplicação de calos primários e embriogênicos de dendezeiro (Elaeis guineensis Jacq.) após 90 dias de cultivo, obtidos a partir de folhas imaturas. A. Multiplicação de calo primário em meio líquido. B. Multiplicação de calo embriogênico em meio líquido. C. Multiplicação de calo primário em meio sólido D. Multiplicação de calo embriogênico em meio sólido. Barras: A. 0,7 cm; B. $0,9 \mathrm{~cm}$; D. $1,0 \mathrm{~cm}$; E. $1,0 \mathrm{~cm}$.

Figura 7. Teste histoquímico de calos primários e embriogênicos de dendezeiro (Elaeis guineensis Jacq.) multiplicados em meio líquido usando azul de Evans e carmim acético, após 90 dias de cultivo. A. Células não embriogênicas dispersas no meio nutritivo coradas de azul; B. Início de aglomeração celular com presença de células embriogênicas, coradas de vermelho e células não embriogênicas coradas de azul. Abreviações: cem = células embriogênicas; cne = células não embriogênicas. Barras: A-B. 0,2 mm.

Figura 8. Aspectos morfológicos dos cultivos durante as etapas de diferenciação de embriões somáticos $(A-B)$ e regeneração de plantas $(C)$ de dendezeiro (Elaeis guineensis Jacq.). Barras: A. 2,0 mm; B. 1,2 mm; C. 2,0 $\mathrm{mm}$

Figura 9. Aspectos morfológicos dos cultivos durante a etapa enraizamento/alongamento dos regenerantes $(A)$ e aclimatização das mudas (B) de dendezeiro (Elaeis guineensis Jacq.). Barras: A. 4,0 cm; B. 11,7 $\mathrm{cm}$.

\section{CAPÍTULO 2}

Figura 1. Caracterização morfoanatômica de folhas imaturas originadas de plantas adultas de dendezeiro (Elaeis guineensis Jacq.) utilizada como explante inicial na indução da embriogênese somática. A. Aspecto externo de segmentos de folha imatura; B. Secção transversal da nervura mediana: notar sistema vascular nítido, com tecido esclerenquimático contornando a região vascular; $\mathrm{C}$ e D. Secções transversais da ala foliar. C. Setas indicando feixes vasculares. Abreviações: $a b=$ abaxial; $a d=$ adaxial; $c s$ = câmara subestomática; ep = 84 
epiderme; est = estômato; $\mathrm{fv}=$ feixe vascular; $\mathrm{fl}=$ floema; $\mathrm{hp}=$ hipoderme; $\mathrm{pl}=$ parênquima lacunoso; $\mathrm{pp}=$ parênquima paliçádico; te $=$ tecido esclerenquimático; $x=$ xilema. Barras: A. $2 \mathrm{~mm}$; B-C. 0,2 mm; D. 0,05 $\mathrm{mm}$.

Figura 2. Segmento foliar imaturo de dendenzeiro (Elaeis guineensis Jacq.) originário de plantas adultas com formação de calo primário após 60 dias de cultivo em meio de indução, contendo $225 \mu \mathrm{m}$ de Picloram. Aspecto morfológico da formação de calos. A. Morfologia externa. B-F. Secção transversal da folha com calo. B. Setas indicando feixes vasculares bem desenvolvidos. Abreviações: $a b=$ abaxial; $a d=$ adaxial; $C=$ calo; $\mathrm{ep}=$ epiderme; $f v=$ feixe vascular; $F=$ folha; $p p=$ parênquima paliçádico. Barras: $A$. $2 \mathrm{~mm} ; \quad$ B. $0,2 \mathrm{~mm}$; C-D. $0,05 \mathrm{~mm} ; \quad$ E. $0,5 \mathrm{~mm} ; \quad$ F. 0,2 $\mathrm{mm}$.

Figura 3. Segmento foliar imaturo de dendezeiro (Elaeis guineensis Jacq.) originário de plantas adultas que não reagiu à indução de calo primário, após 180 dias de cultivo em meio contendo $225 \mu \mathrm{M}$ de Picloram. A. Morfologia externa. B-D. Secção transversal da folha sem a formação de calo. B. Ocorrência feixes vasculares pouco desenvolvidos (setas). Abreviações: $a b=$ abaxial; $\mathrm{ad}=$ adaxial; $\mathrm{ep}=$ epiderme; $\mathrm{fv}=$ feixe vascular; $\mathrm{fl}=$ floema; $\mathrm{hp}=$ hipoderme; $x=$ xilema. Barras: A. $2 \mathrm{~mm}$; B. $0,2 \mathrm{~mm}$; C. $0,5 \mathrm{~mm}$; D. 0,5 $\mathrm{mm}$

Figura 4. Segmento foliar imaturo de dendezeiro (Elaeis guineensis Jacq.) originário de plantas adultas com formação de raiz em meio de cultura suplementado com ácido naftalenoacético (ANA) após 180 dias. A. Morfologia externa. B-D. Secção transversal da folha e longitudinal e transversal da raiz. Abreviações: $a b=$ abaxial; $a d=$ adaxial $; C=$ calo; $c f=$ coifa; $f v=$ feixe vascular; $\mathrm{F}=$ folha; $\mathrm{pcx}=$ ponto de conexão; $\mathrm{R}=$ raiz; $\mathrm{rc}=$ região cortical; $r e=$ região epidérmica; $r m r=$ região meristemática da raiz; $r v$ = região vascular. Barras: $\mathrm{A}$. $2 \mathrm{~mm} ; \quad$ B. $0,5 \mathrm{~mm} ; \quad$ C. $0,2 \mathrm{~mm} ; \quad$ D. 0,2 $\mathrm{mm}$.

Figura 5. Aspectos morfológicos e anatômicos do calo primário de dendezeiro (Elaeis guineensis Jacq.) obtido de folhas imaturas de plantas adultas aos 180 dias de cultivo em meio de cultivo contendo $225 \mu \mathrm{M}$ de Picloram. A. Morfologia 
externa. B-D. Secção do calo primário. Setas indicam divisão celular evidenciada pela duplicidade de núcleos nas células. Abreviações: $\mathrm{cpq}=$ células parenquimáticas; $\mathrm{cpc}=$ células periféricas do calo; $\mathrm{zm}=$ zona meristemática. Barras: A. $2 \mathrm{~mm}$; B. $0,2 \mathrm{~mm}$; C. $0,2 \mathrm{~mm}$; D. 0,05 $\mathrm{mm}$.

Figura 6. Aspectos morfológicos e anatômicos do calo embriogênico formado a partir de células do calo primário de dendezeiro (Elaeis guineensis Jacq.), após 180 dias de cultivo em meio contendo $225 \mu \mathrm{M}$ de Picloram. A. Morfologia externa. B-D. Secção do calo embriogênico e do calo primário. Abreviações: $C E$ = calo embriogênico; $\mathrm{CP}=$ calo primário. Barras: A. $2 \mathrm{~mm}$; B. 0,5 mm; C. 0,2 $\mathrm{mm}$; D. 0,05 mm.

Figura 7. Aspectos morfológicos e anatômicos do calo embriogênico obtido a partir da indução de folhas jovens de dendezeiro (Elaeis guineensis Jacq.). A. Morfologia externa. B-D. Secção do calo embriogênico. C. Setas indicam divisão celular. B. Setas indicam a região em que foi observado o início de organização celular C. Setas indicam duplicidade de núcleos caracterizado pela intensa divisão celular. D. Setas indicam a linearização celular para a formação de embriões somáticos. Abreviações: $\mathrm{CE}=$ calo embriogênico. Barras: A. 2 $\mathrm{mm}$; B. $0,5 \mathrm{~mm}$; C. $0,05 \mathrm{~mm}$; D. 0,05 mm.

\section{CAPÍTULO 3}

Figura 1. Aspecto morfológico dos estádios de indução e multiplicação utilizados na caracterização bioquímica da embriogênese somática de folhas imaturas de dendezeiro (Elaeis guineensis Jacq.). A. Folha com zero dias de cultivo (controle); B. Folha que não reagiu; C. Folha com raiz; D. Folha contendo calo; E. Calo primário isolado; F. Calo embriogênico. Barras: 2 $\mathrm{mm}$

Figura 2. Teores de açúcares solúveis totais nos estádios de desenvolvimento obtidos durante a indução da embriogênese somática de folhas imaturas de plantas adultas dendezeiro (Elaeis guineensis Jacq.). Abreviações: $N R=$ folha que não reagiu; $F L+R Z$ = folha com raiz; $F L+C L=$ folha com calo primário; $\mathrm{CP}$ = calo primário; $\mathrm{CE}$ = calo embriogênico. Os dados representam as médias seguidas dos erros padrões. Médias seguidas pela mesma letra não diferem 
estatisticamente entre si pelo teste de Scott-Knott a $5 \%$ de probabilidade.

Figura 3. Teores de glicose, frutose e sacarose nos estádios de desenvolvimento obtidos durante a indução da embriogênese somática de folhas imaturas de plantas adultas dendezeiro (Elaeis guineensis Jacq.). Abreviações: $N R=$ folha que não reagiu; $F L+R Z$ = folha com raiz; $F L+C L=$ folha com calo primário; $\mathrm{CP}=$ calo primário; $\mathrm{CE}=$ calo embriogênico. Os dados representam as médias seguidas dos erros padrões. Médias seguidas pela mesma letra não diferem estatisticamente entre si pelo teste de Scott-Knott a $5 \%$ de probabilidade na comparação dos índices de cada açúcar entre os diferentes estádios embriogênicos.

Figura 4. Abundâncias relativas de glicose, frutose e sacarose nos estádios de desenvolvimento obtidos durante a indução da embriogênese somática de folhas imaturas de plantas adultas dendezeiro (Elaeis guineensis Jacq.). Abreviações: $N R=$ folha que não reagiu; $F L+R Z$ = folha com raiz; $F L+C L=$ folha com calo primário; $\mathrm{CP}=$ calo primário; $\mathrm{CE}=$ calo embriogênico

Figura 5. Teores de amido nos estádios de desenvolvimento obtidos durante a indução da embriogênese somática de folhas imaturas de plantas adultas dendezeiro (Elaeis guineensis Jacq.). Abreviações: $N R=$ folha que não reagiu; $\mathrm{FL}+\mathrm{RZ}=$ folha com raiz; $\mathrm{FL}+\mathrm{CL}=$ folha com calo primário; $\mathrm{CP}=$ calo primário; $\mathrm{CE}$ = calo embriogênico. Os dados representam as médias seguidas dos erros padrões. Médias seguidas pela mesma letra não diferem estatisticamente entre si pelo teste de Scott-Knott a $5 \%$ de probabilidade.

Figura 6. Teores de ácidos graxos totais nos estádios de desenvolvimento obtidos durante a indução da embriogênese somática de folhas imaturas de plantas adultas dendezeiro (Elaeis guineensis Jacq.). Abreviações: $N R=$ folha que não reagiu; $F L+R Z$ = folha com raiz; $F L+C L$ = folha com calo primário; $\mathrm{CP}=$ calo primário; $\mathrm{CE}$ = calo embriogênico. Os dados representam as médias seguidas dos erros padrões. Médias seguidas pela mesma letra não diferem estatisticamente entre si pelo teste de Scott-Knott a $5 \%$ de probabilidade 
Figura 7. Teores de açúcares solúveis totais (AST), amido e ácidos graxos totais (AGT) nos estádios de desenvolvimento obtidos durante a indução da embriogênese somática de folhas imaturas de plantas adultas dendezeiro (Elaeis guineensis Jacq.). Abreviações: $\mathrm{NR}=$ folha que não reagiu; $\mathrm{FL}+\mathrm{RZ}=$ folha com raiz; $\mathrm{FL}+\mathrm{CL}=$ folha com calo primário; $\mathrm{CP}=$ calo primário; $\mathrm{CE}=$ calo embriogênico.

Figura 8. Abundâncias relativas dos ácidos graxos de maior relevância na constituição dos lipídios nos estádios de desenvolvimento obtidos durante a indução da embriogênese somática de folhas imaturas de plantas adultas dendezeiro (Elaeis guineensis Jacq.). Abreviações: $\mathrm{NR}=$ folha que não reagiu; $\mathrm{FL}+\mathrm{RZ}=$ folha com raiz; $\mathrm{FL}+\mathrm{CL}=$ folha com calo primário; $\mathrm{CP}=$ calo primário; $\mathrm{CE}=$ calo embriogênico; $\mathrm{C} 16: 0=$ palmítico; $\mathrm{C} 18: 0=$ esteárico; $\mathrm{C} 18: 1$ = oléico; $\mathrm{C} 18: 2$ = linoléico; $\mathrm{C} 18: 3$ = linolênico

Figura 9. Teores de aminoácidos totais livres nos estádios de desenvolvimento obtidos durante a indução da embriogênese somática de folhas imaturas de plantas adultas dendezeiro (Elaeis guineensis Jacq.). Abreviações: $N R=$ folha que não reagiu; $F L+R Z$ = folha com raiz; $F L+C L=$ folha com calo primário; $\mathrm{CP}=$ calo primário; $\mathrm{CE}$ = calo embriogênico. Os dados representam as médias seguidas dos erros padrões. Médias seguidas pela mesma letra não diferem estatisticamente entre si pelo teste de Scott-Knott a $5 \%$ de probabilidade.

Figura 10. Teores de prolina nos estádios de desenvolvimento obtidos durante a indução da embriogênese somática de folhas imaturas de plantas adultas dendezeiro (Elaeis guineensis Jacq.). Abreviações: $N R=$ folha que não reagiu; $\mathrm{FL}+\mathrm{RZ}=$ folha com raiz; $\mathrm{FL}+\mathrm{CL}=$ folha com calo primário; $\mathrm{CP}=$ calo primário; $\mathrm{CE}=$ calo embriogênico. Os dados representam as médias seguidas dos erros padrões. Médias seguidas pela mesma letra não diferem estatisticamente entre si pelo teste de Scott-Knott a $5 \%$ de probabilidade.

Figura 11. Teores de proteínas totais nos estádios de desenvolvimento obtidos durante a indução da embriogênese somática de folhas imaturas de plantas adultas dendezeiro (Elaeis guineensis Jacq.). Abreviações: $\mathrm{NR}=$ folha que não reagiu; $\mathrm{FL}+\mathrm{RZ}=$ folha com raiz; $\mathrm{FL}+\mathrm{CL}=$ folha com calo primário; $\mathrm{CP}=$ calo 
primário; $\mathrm{CE}$ = calo embriogênico. Os dados representam as médias seguidas dos erros padrões. Médias seguidas pela mesma letra não diferem 138 estatisticamente entre si pelo teste de Scott-Knott a $5 \%$ de probabilidade.

Figura 12. Perfil metabólico das etapas envolvidas na indução de calos a partir de folhas jovens de dendenzeiro (Elaeis guineensis Jacq.). Médias seguidas pela mesma letra não diferem estatisticamente entre si pelo teste de Scott-Knott a $5 \%$ de probabilidade. Cada nó da figura corresponde a um composto presente no fluxo metabólico. Os nós que não exibem o gráfico com as dosagens apresentadas, representam os compostos que não tiveram níveis suficientes de detecção pelo equipamento. Os nós com os gráficos apresentados representam, de forma resumida, uma via específica de síntese ou degradação de algum composto. Na figura não foi compreendido todo o metabolismo, somente os compostos detectados e as vias aos quais estão relacionados de forma resumida. As setas indicam apenas quais os compostos estão interligados no metabolismo, não indicando necessariamente o sentido da reação. Os dados de Glicose, Frutose, Sacarose e Amido são os mesmos $\begin{array}{lllllll}\text { encontrados na } & \text { seção } & 3.1 . & \text { AST } & \text { e } & 3.2 \text {. }\end{array}$ Amido 


\section{SÍMBOLOS E ABREVIAÇÕES}

$\%$ - Por cento

2,4-D - Ácido diclorofenoxiacético

2-iP - Isopenteniladenina

AB - Face abaxial

AD - Face adaxial

AIA - Ácido indolacético

AIB - Ácido indol butírico

AMG - Amiloglucosidase

AML - Amiloplastos

ANA - Ácido naftalenoacético

ANOVA - Análise de variância

AST - Açúcares solúveis totais

Atm - Atmosfera

ATP - Adenosina trifosfato

BAP - 6-benzilaminopurina

BSA - Albumina de soro bovino

C - Calo

C.V. - Coeficiente de variação

C14:0 - Ácido mirístico

C15:0 - Ácido pentadecílico

C16:0 - Ácido palmítico

C18:0 - Ácido esteárico

C18:1 - Ácido oléico

C18:2 - Ácido linoléico

C18:3 - Ácido linolênico

C20:0 - Ácido araquídico

C20:1 - Ácido gadoléico

C22:0 - Ácido behênico

C22:1 - Ácido erúcico

CAM - Câmbio

CE - Calo embriogênico

cm - Centímetro 
$\mathbf{c m}^{2}$ - Centímetro quadrado

Col - Colênquima

CP - Calo primário

EP - Epiderme

EST - Estômato

et al. - E colaboradores

EV - Elemento de vaso

FAA - Formaldeído, ácido acético glacial e álcool etílico

FI - Floema

FV - Feixe vascular

g - Grama

GODPOD - Glicose PAP Liquiform/ Centerlab

L - Litro

m - Metro

M - Molar

$\mathbf{m}^{2}$ - Metro quadrado

mg - Miligrama

MGM - Meio de germinação

$\mathrm{mL}$ - Mililitro

mm - Milímetro

mM - Milimolar

MSC - Massa seca

MS - Murashige \& Skoog

$\mathbf{N}$ - Normal

$\mathrm{NaOCl}$ - Hipoclorito de sódio

$\mathrm{NaOH}$ - Hidróxido de sódio

nmol - Nanomol

oC - Grau Celsius

PA - Parênquima

PC - Procâmbio

Pcl - Parênquima clorofiliano

PD - Protoderme

pH - Potencial hidrogeniônico

Phytagel - Agente gelificante 
Picloram - Ácido aminotricloropicolínico

PL - Parênquima lacunoso

PP - Parênquima paliçádico

rpm - Rotação por minuto

s-Segundo

U - Unidade

$\mathbf{v} / \mathbf{v}$ - Volume por volume

W - Watt

X - Xilema

$\mathbf{g g}$ - Micrograma

$\mu \mathrm{L}$ - Microlitro

$\mathbf{M M}$ - Micro molar

$\boldsymbol{\mu m}$ - Micrometro

$\mu \mathrm{mol}$ - Micromol 


\section{Aprimoramento da embriogênese somática de dendezeiro \\ (Elaeis guineensis Jacq.), a partir de folhas de plantas adultas: Influência do genótipo e caracterização morfoanatômica e bioquímica}

\section{RESUMO}

O objetivo do presente trabalho foi aperfeiçoar $e$ avaliar estruturalmente $e$ bioquimicamente as etapas de indução e multiplicação de linhagens embriogênicas de dendezeiro (Elaeis guineensis Jacq.) originadas a partir de folhas imaturas de plantas adultas de alto rendimento. Para a indução, segmentos de folhas da variedade B35-1729 foram inoculadas em meio de cultura de MS, contendo cinco concentrações $(0,225$, 450, 675 e $900 \mu \mathrm{M})$ de ANA, 2,4-D e Picloram. Em seguida foram avaliadas duas regiões do palmito (apical e basal) na indução de calos em seis variedades (B35-29-32, B35-29-33, B35-17-33, B35-17-29, A25-15-11 e A25-14-28). Para a multiplicação, duas consistências de meio (líquido e sólido) e dois tipos de explantes (calo primário e embriogênico) da variedade B35-17-29 foram testados. A caracterização morfoanatômica e a extração e quantificação dos açúcares, amido, ácidos graxos, aminoácidos, proteínas e a análise do perfil metabólico contidos em explantes foliares aos zero dias de cultivo, com raízes, com calos e que não reagiaram, além de calo primário, calo embriogênico e calo embriogênico formado, a partir de calo primário, foi realizada utilizando-se materiais do genótipo B35-17-33. Verificou-se que as melhores taxas de indução de calos da variedade B35-17-29 foram obtidas com a utilização de 2,4-D $(900 \mu \mathrm{M})$ e Picloram $(225 \mu \mathrm{M})$. Analisando os genótipos e as posições das folhas verificou-se que as melhores taxas foram observadas com a inoculação da parte apical em todos os genótipos testados. Na multiplicação, verificou-se que o maior ganho de biomassa fresca foi observado com a multiplicação de calos embriogênicos em meio líquido sob agitação. Anatomicamente, verificou-se que os explantes foliares utilizados para a indução de calos apresentavam epiderme unisseriada, com estômatos apenas na face abaxial da folha, presença de hipoderme bi-estratificada, em ambas as faces, com mesofilo dorsiventral. Foi possível observar o desenvolvimento inicial dos calos associados aos feixes vasculares em $100 \%$ dos propágulos analisados. Na formação do calo primário, as divisões celulares começam próximo aos feixes vasculares. Foi observado que calos primários são constituídos por células meristemáticas apenas em 
sua região mais interna, enquanto que calos embriogênicos são compostos inteiramente por este tipo celular. A partir do calo embriogênico, é verificada a formação de embriões somáticos. Com relação às análises bioquímicas, verificou-se que não há diferenças significativas entre as concentrações de açúcares nos segmentos foliares que se mostraram responsivos ou não à indução da embriogênese somática. Em contrapartida, folhas com calos apresentaram níveis inferiores de frutose, e maiores concentrações de amido, quando comparadas àquelas que não reagiram. Verificou-se que calos primários apresentaram maiores concentrações de açúcares e amido quando comparados com calos embriogênicos, diferindo também por apresentarem concentrações mais elevadas de sacarose. Com relação à concentração dos ácidos graxos, não houve diferença significativa entre explantes foliares com calos e aqueles que não reagiram. Os teores de aminoácidos apresentam um acúmulo gradativo durante a etapa da indução de calos. Em todo o cultivo, apenas calos embriogênicos apresentaram as maiores concentrações de prolina. Explantes foliares com zero dias de cultivo e aqueles que não reagiram apresentaram níveis intermediários de proteínas, sendo observada a redução das taxas com a formação dos calos primários e aumento quando no caso de tratar-se de calos embriogênicos.

Palavras-chave: Arecaceae; micropropagação; embriogênese somática; morfogênese; ontogênese; histologia; fisiologia. 


\section{African oil palm tree (Elaeis guineensis Jacq.) somatic embryogenesis enhancement, from leaves of adult plants: Genotype's influence and morphoanatomic and biochemistry description}

\section{ABSTRACT}

The main goal of the current project was enhancing and evaluating biochemically and structurally the induction and multiplication steps of the African oil palm tree's (Elaeis guineensis Jacq.) embryogenic lineage spread originally from high performance adult plant's half-grown leaves. In order to induct, leave's cantle from the variety B35-17-29 were inoculated in MS cultivation environment, containing 5 concentrations $(0,225,450$, 675 e $900 \mu \mathrm{M})$ of NAA, 2,4-D and Picloram. Subsequently, two heart of palm's zones were evaluated (apical and basal) during calluses induction in 6 varieties (B35-29-32, B35-29-33, B35-17-33, B35-17-29, A25-15-11 e A25-14-28). For the multiplication, two media consistencies (solid and liquid) and two sorts of explant (primary and embryogenic callus) from B35-17-29's variety were tested. The morpho-anatomic characterization and the extraction and quantification of the sugars, starch, fatty acids, amino acids and proteins and the metabolic profile analysis contained in foliar explants on zero days of cultivation with roots, with callus and which did not react, besides primary callus, embryogenic callus and full-grown embryogenic callus, from primary callus, was carried out using materials from the genotype B35-17-33. It has been observed that the best calluses induction rates from the variety B35-17-29 were obtained with the use of 2,4-D $(900 \mu \mathrm{M})$ and Picloram $(225 \mu \mathrm{M})$. Analyzing the genotypes and the position of the leaves it's been found that the best rates were observed with the inoculation of the apical part in all tested genotypes. On the multiplication, it was verified that the best fresh biomass gain was seen with embryogenic calluses multiplication in stirring liquid media. Anatomically, it was verified that the foliar explants used for calluses induction presented uniseriate epidermis, with stomas only on the abaxial face, bi-stratified hypodermis presence, on both faces, with dorsiventral mesophilic. It could be observed the initial development of the calluses associated to vascular bundles in $100 \%$ out of the propagating material analyzed. On the primary callus formation, the cell divisions begin around the vascular bundles. It's been observed that the primary calluses are only made up of meristematic cells in its more internal area, whilst embryogenic calluses are fully made up of these cells. From 
the embryogenic callus, the somatic embryos formation is seen. Regarding the biochemical analysis, it's verified that there are no considerable differences between the sugar content in the foliar segments which was proved to be responsive or not to the somatic embryogenic induction. On the other hand, leaves with calluses presented lower fructose levels and higher starch concentration when compared with those that didn't react. It was found that primary calluses presented higher concentration of sugar compared with embryogenic calluses, which also differs for presenting higher sucrose concentration. In regard to fatty acids concentration, there wasn't a major difference between foliar explants with calluses and those that didn't react. The amino acids content presented gradual increase during the calluses induction step. In every cultivation, only embryogenic calluses presented higher proline concentration. Foliar explants with zero cultivation days and those that didn't react presented intermediate protein levels, being noticed a reduction of the rates with the formation of primary calluses and enhancement in case of embryogenic calluses.

Keywords: Arecaceae; micropropagation; somatic embryogenesis; morphogenesis; ontogenesis; histology; physiology. 


\section{INTRODUÇÃO GERAL}

A comunidade internacional tem buscado novas fontes de energia sustentáveis, com o objetivo de substituir ou complementar a matriz energética mundial (Leite \& Leal, 2007; Hong, 2012, Desai \& Venkatachalam, 2012, Saifuddin et al., 2014).

Por ser um país que pode se destacar na produção de biocombustíveis, o Brasil tem se mobilizado na busca de novas fontes de energia para atender tanto ao mercado nacional quanto o internacional. Nesse contexto, o governo federal lançou, em 2002, o Programa Brasileiro de Biocombustíveis, com o objetivo de viabilizar a produção de biodiesel no país (Ramos \& Wilhelm, 2005; Ferreira et al., 2012).

De fato, o Brasil se destaca no cenário mundial por possuir mais de $20 \%$ da área agricultável do planeta, mais de $10 \%$ da água doce do mundo e mais de 200 espécies de plantas com possibilidade de produção de óleo vegetal (Gontijo et al., 2011). Entre as mais de 200 espécies potenciais de plantas oleaginosas, o dendezeiro (Elaeis guineensis Jacq.) ocupa posição de destaque, por ser uma das espécies que apresenta maior produtividade de óleo no mundo. Na classificação atual, o dendezeiro pertence à classe Liliopsida, ordem Arecales, família Arecaceae (Palmae), subfamília Arcoideae e gênero Elaeis (Jouannic et al., 2011). Seu rendimento anual pode atingir cerca de 5 a 7 toneladas de óleo por hectare, que corresponde a pelo menos 1,2 vezes a produtividade do óleo de macaúba, 1,5 vezes a de côco, 2 vezes a do óleo de oliveira e 10 vezes a do óleo de soja. Além disso, apresenta a vantagem de poder ser explorado comercialmente por períodos superiores a 25 anos, mantendo o solo coberto, contruibuindo para evitar o aquecimento global e o aumento de $\mathrm{CO}^{2}$ na atmosfera (Wahid et al., 2005).

No Brasil, programas de melhoramento genético do dendezeiro têm sido implementados. No entanto, genótipos melhorados podem apresentar produção limitada de sementes, além de baixa taxa de germinação e produção de plantas desuniformes, pois os genitores são plantas alógamas que apresentam alta heterozigose. Ressalte-se ainda que, por se tratar de uma espécie monocotiledônea típica, o dendezeiro possui um único ápice crescente, sem perfilhamento, impedindo que sua multiplicação seja feita vegetativamente por meios convencionais (Martine et al., 2009; Chanprasert et al., 2012; Ferreira et al., 2012; Montoya et al., 2014; Barcelos et al., 2015; Gomes et al., 2015). 
Diante disso, a micropropagação por embriogênese somática pode ser uma excelente alternativa para a multiplicação clonal de genótipos elite desta espécie (Duval et al., 1988; Durand-Gasselin et al., 1990; Rival et al., 1997). O método baseia-se no desenvolvimento de embriões a partir de células haploides ou somáticas, sem que haja a fusão de gametas, podendo, assim, possibilitar a formação de milhares de plantas idênticas à planta matriz (Reinert, 1958).

Protocolos de propagação clonal de dendezeiros por embriogênese somática, a partir de embriões zigóticos, já estão relativamente adiantados quanto ao desenvolvimento da técnica, inclusive no Brasil (Teixeira et al., 1993; Gomes, 2012; Silva et al., 2012; Balzon et al., 2013). Porém, embora a utilização desse tipo de explante apresente diversas vantagens, como a grande disponibilidade e a facilidade de transporte ele não permite a clonagem de indivíduos adultos, por tratar-se de material de origem reprodutiva. Sendo assim, a utilização de tecidos somáticos de plantas adultas, em especial, folhas como explante inicial, surge como uma necessidade para a propagação clonal de indivíduos já fenotipados em campo (Duval et al., 1988), cujas características de interesse agronômico podem se resumir a uma ou poucas plantas.

$\mathrm{Na}$ embriogênese somática, o estabelecimento de células, tecidos ou órgãos de plantas em condições controladas, tem como consequência a interrupção do controle hormonal a que estas células estavam submetidas em seu ambiente natural. Quando expostas a uma nova condição ambiental, as células vegetais podem expressar um potencial morfogênico que não se expressaria fora desse ambiente (Osborne, 1965; Mozer, 1980; Trewavas, 1983; Gómez-Cadenas et al., 2000; Bari \& Jones, 2009). As condições de cultivo podem tanto permitir a continuidade de um padrão de desenvolvimento inviabilizado na planta, quanto promover a desdiferenciação e a neomorfogênese vegetal (Staritsky, 1970). Sendo assim, as etapas que constituem estes eventos podem ser detalhadas e acompanhadas pelo emprego de técnicas de análise anatômica (Silva et al., 2013).

De fato, a possibilidade de manipulação do sistema de cultivo in vitro para fins tecnológicos depende do domínio preciso de princípios da fisiologia do desenvolvimento. Dessa forma, estudos bioquímicos, associados aos estudos morfológicos e histológicos, estão sendo realizados durante a embriogênese somática em diferentes espécies de plantas, proporcionando uma grande quantidade de 
informações, incluindo àquelas associadas às alterações bioquímicas relacionadas com a indução da competência embriogênica (Komamine el al., 1991; Gomes et al., 2014).

Nesse contexto, o presente trabalho objetivou aperfeiçoar e avaliar estruturalmente e bioquimicamente as etapas de indução e multiplicação de linhagens embriogênicas de dendezeiros originadas a partir de folhas imaturas de plantas adultas de alto rendimento. 


\section{REVISÃO DE LITERATURA}

\subsection{Aspectos gerais do dendezeiro (Elaeis guineensis Jacq.)}

A denominação da espécie Elaeis guineensis foi proposta em 1763 pelo botânico Nicholaus Joseph Jacquin, onde o nome genérico Elaeis foi derivado da palavra grega elaion, que significa óleo e o epíteto específico, guineensis, se refere ao centro de origem da espécie (Guiné-Bissau) (Tregear et al, 2011). Na classificação atual, a espécie pertence à classe Liliopsida, ordem Arecales, família Arecaceae (Palmae), subfamília Arcoideae e gênero Elaeis (Jouannic et al., 2011). O dendezeiro é uma espécie amplamente cultivada em regiões tropicais e úmidas da África, Ásia e América. Acredita-se que essa cultura tenha sido trazida para o Brasil por escravos africanos, por volta de 400 anos atrás, onde se adaptou facilmente ao clima tropical das regiões Norte e Nordeste do país, devido à presença de condições de temperatura e umidade muito semelhantes àquelas encontradas em seu centro de origem (Gontijo et al., 2011; Abrapalma, 2016).

O dendezeiro é uma monocotiledônea oleaginosa perene que atinge em média de 15 - $18 \mathrm{~m}$ de altura, ou até $30 \mathrm{~m}$ quando em plantios adensados. Possui um sistema radicular fasciculado e seu caule é um estipe ereto sem perfilhamento (Figura 1). Suas folhas são pinadas, medindo de 5 a $7 \mathrm{~m}$, compostas por um eixo central subdividido em duas partes: basal, denominada pecíolo, que se liga ao estipe, apresentando comprimento de aproximadamente $1,5 \mathrm{~m}$ e a parte distal denominada ráquis, responsável pela sustentação dos folíolos (segmentos da lâmina foliar). Possuem inflorescências axilares, denominadas espádices, compostas por espigas protegidas por duas brácteas fibrosas, as espatas. Por ser uma planta monoica, o dendezeiro apresenta inflorescências masculinas e femininas simultaneamente na mesma planta. Apesar de ser uma planta monoica, o dendezeiro produz inflorescências de ambos os sexos em ciclos alternados, que por não se sobreporem, induzem à fecundação cruzada caracterizando o dendezeiro como uma planta alógama (Jourdan \& Rey, 1997; Adam et al., 2005; Jouannic et al., 2011).

O fruto do dendezeiro se desenvolve em cachos ovais, atingindo um comprimento médio de $50 \mathrm{~cm}$, com largura de cerca de $35 \mathrm{~cm}$ e pesando de 20 a 30 kg. Cada cacho é composto por aproximadamente 1500 frutos (Figura 1). O fruto é uma 
drupa séssil, com formato esférico e alongado, medindo de 2 a $5 \mathrm{~cm}$ de comprimento e entre 3 e $30 \mathrm{~g}$ de peso (Adam et al., 2005).

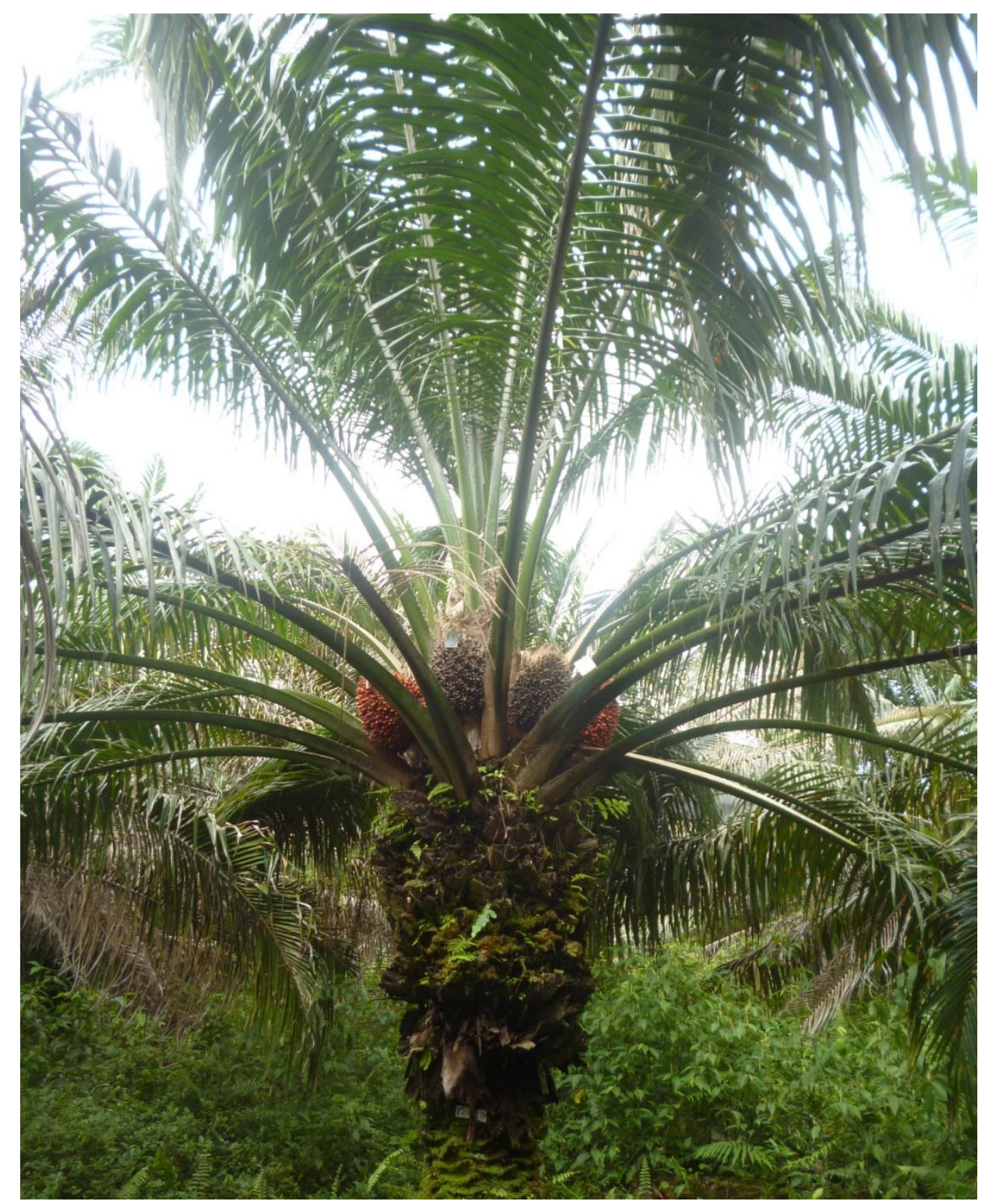

Figura 1. Aspecto geral da morfologia de um híbrido superior de dendezeiro (Elaeis guineensis Jacq.) de alta produtividade, com crescimento vertical do caule reduzido. Foto: Jonny Everson Scherwinski-Pereira, Rio Preto da Eva, AM, 2012.

Essa espécie possui um mesocarpo espesso que corresponde a $92 \%$ do fruto e contêm de 20 a $50 \%$ de óleo de dendê. Em sua camada interna, são encontradas amêndoas que produzem um óleo com características físico-químicas distintas das 
encontradas no óleo de dendê, que é comumente conhecido como óleo de palmiste (Sumathi et al., 2008).

A importância econômica do dendezeiro advém das características bioquímicas presentes no mesocarpo de seus frutos que o colocam como um dos mais promissores para a produção de óleo com alto poder calorífico. No entanto, a espessura do endocarpo é controlada geneticamente por um gene denominado Sh, classificando as plantas em três tipos: Elaeis guineensis Jacq. var. dura Becc. é um indivíduo homozigoto, com genes $\mathrm{Sh}+\mathrm{Sh}+$ e endocarpo com espessura medindo de 2 a $6 \mathrm{~mm}$.; Este tipo corresponde à planta em que se utiliza a flor feminina nos cruzamentos intraespecíficos. Elaeis guineensis Jacq. var. psifera Becc. é uma planta homozigota, com genes Sh-/Sh- e endocarpo reduzido ou até mesmo ausente. Este tipo fornece grãos de pólen para os cruzamentos intraespecíficos. Por fim, tem-se o Elaeis guineensis Jacq. var. tenera Becc., que corresponde ao híbrido gerado pelo cruzamento entre psifera e dura, sendo um indivíduo heterozigoto, com genes Sh+/She endocarpo medindo de 0,5 a $4 \mathrm{~mm}$ de espessura. Este tipo possui sementes indicadas para plantios comerciais por apresentar uma vida útil no campo de 20 a 30 anos (Hameed \& Chin, 2009; Adam et al., 2011; Mukherjee \& Sovacool, 2014; Oosterveer, 2014).

A cultura do dendezeiro possui ampla importância em diversos setores, com destaque no cenário energético, ecológico e na indústria de diferentes produtos. O óleo de dendê é usado direta ou indiretamente na alimentação, fazendo parte de margarinas, gorduras para pães, biscoitos, massas e tortas, pós para sorvete, manteigas vegetais, óleos de cozinha, óleos de salada e azeites. Na indústria, o óleo de dendê é usado na produção de sabões, sabonetes, xampus, condicionadores para cabelo, velas, tintas, detergentes e, nos últimos anos, utilizado também na produção de biodiesel. Já o óleo de palmiste, além de ser utilizado na alimentação animal e em adubos vegetais, é utilizado pela indústria na fabricação de batons e perfumes (Yengar, 2002; Sundram et al., 2003), e nos últimos anos, também vêm constituindo um importante insumo para a produção de bicombustíveis (Adam et al., 2005; Wahid et al., 2005).

Diante disso, o óleo vegetal produzido pelo dendezeiro tem ocupado, nos últimos anos, um lugar de destaque na produção mundial de óleos e gorduras. Prova disso, foi o expressivo crescimento na participação deste óleo no mercado mundial, que com 
produção de aproximadamente 60 milhões de toneladas ao ano, consolidou-se como o óleo vegetal mais produzido em todo o mundo (Hansen et al., 2015).

Por ser uma das oleaginosas mais produtivas que se tem conhecimento, o dendezeiro é uma das espécies mais promissoras para a criação de um modelo alternativo de geração de energia pela utilização do seu óleo para a produção de biocombustível. Além disso, quando cultivado sob condições edafoclimáticas favoráveis, o dendezeiro constitui-se uma cultura permanente, normalmente de produção continuada e com possibilidade de ser explorada por pelo menos 25 anos (Wahid et al., 2005). Quando atinge o estágio adulto, a planta oferece considerável proteção ao solo, podendo ser cultivada isoladamente ou associada a outras culturas, sendo uma espécie altamente recomendada para plantios em áreas degradadas, como as da Amazônia (Wahid et al., 2005).

O dendezeiro é fortemente influenciado pelas condições ambientais. Devido às necessidades de alta pluviosidade e temperatura, a cultura do dendezeiro apresenta melhor desenvolvimento em regiões tropicais, com clima equatorial quente e úmido e precipitação pluviométrica elevada e bem distribuída ao longo do ano (Carvalho et al., 2001). Embora as altas temperaturas favoreçam o desenvolvimento do dendezeiro, o fator que exerce grande influência é a disponibilidade de água no ambiente em que a cultura é estabelecida, sendo um fator indispensável para o cultivo. Segundo Surre \& Ziller (1969) e Duval et al. (1988), a baixa disponibilidade hídrica pode influenciar no número de inflorescências emitidas pela planta, ocasionando na redução considerável do número de cachos produzidos, bem como no aumento do abortamento das inflorescências.

Devido às condições climáticas oferecidas, o dendezeiro é amplamente cultivado na América Latina e Sudoeste da Ásia. Os cinco maiores produtores dessa cultura são a Indonésia, Malásia, Tailândia, Colômbia e Nigéria, com produções estimadas para 2015/2016, respectivamente, de 35, 21, 2,3, 1,28 e 0,97 milhões de toneladas. A Indonésia, juntamente com a Malásia, corresponde a $90 \%$ da produção mundial (Nantha \& Tisdell, 2009; USDA, 2013).

No Brasil, o estado que apresenta a maior produção é o Pará, responsável por aproximadamente $85 \%$ do óleo produzido. No entanto, considerando-se apenas dois estados da Amazônia, estima-se que o Brasil disponha de cerca de 70 milhões de hectares adequados para essa cultura, sendo 50 milhões no Estado do Amazonas e 20 
milhões no Pará. Essas áreas têm condições de produzir dendê para absorver grandes demandas internas e externas, o que tornaria o Brasil um dos maiores produtores dessa cultura (Gontijo et al., 2011). De acordo com Boddey (1993) se 30\% da área desflorestada da Amazônia brasileira fosse utilizada para o plantio dessa palmeira, seria possível suprir a demanda diária de 460 mil barris de óleo diesel consumidos no país, bem como, gerar empregos para a população da região.

Embora o dendezeiro seja cultivado no Brasil e no mundo, o método de propagação da espécie é um fator limitante para cobrir o território disponível para essa espécie e alcançar um patamar de produção de óleo que atenda a demanda mundial. Diante disso, nos programas de melhoramento genético, a multiplicação de genótipos superiores ocorre exclusivamente por meio de sementes, tornando praticamente impossível a obtenção de culturas uniformes e a perpetuação das características selecionadas de indivíduos de alto valor genético, em ciclos precoces de seleção (Jouannic et al., 2011).

\subsection{A Cultura de tecidos de plantas}

A cultura de tecidos de plantas é uma ferramenta biotecnológica que envolve diferentes técnicas, pela qual um explante (célula, tecido ou órgão) é cultivado de forma asséptica em um meio nutritivo, sob condições controladas de temperatura e luminosidade (Guerra \& Handro, 1998; Saxena \& Dhawan, 1999; Rezende et al., 2008; Menéndez-Yuffá et al., 2010; Soh et al., 2011; You et al., 2012). O princípio da cultura de tecidos vegetais se baseia na teoria celular da totipotencialidade, ou seja, na capacidade de células vegetais poderem originar um novo indivíduo, em razão de toda a informação genética necessária para a regeneração completa de outra planta estar presente no ambiente celular (Gautheret, 1983). Somente em 1902 é que o botânico alemão Haberlandt mostrou a aplicação prática desta teoria in vitro, culminando com a formulação do conceito de cultura asséptica de células ao cultivar células de tecidos somáticos de plantas em solução nutritiva (Krikorian \& Berquam, 1969).

As principais técnicas da cultura de tecidos vegetais são constituídas da propagação clonal de mudas em larga escala (micropropagação), da regeneração de plantas livres de vírus e patógenos (limpeza clonal), da conservação de recursos 
genéticos de plantas (conservação de germoplasma) e da produção de plantas trangênicas (Abdullah et al., 2005; Soh et al., 2011; Gantait et al., 2015).

Mas para que o sucesso das diferentes técnicas da cultura de tecidos seja alcançado, é necessário que ocorra o crescimento e a diferenciação celular dos explantes utilizados. O crescimento e o desenvolvimento das plantas são controlados por substâncias orgânicas naturais denominadas fitormônios. Estas são sintetizadas em pequenas concentrações e em determinadas regiões das plantas, sendo distribuídas para diferentes órgãos, nos quais exercem suas funções, inibindo ou estimulando processos fisiológicos e/ou bioquímicos vitais. Substâncias com efeitos similares ao de fitormônios podem ser sintetizadas em laboratório e são denominados fitorreguladores (Jiménez, 2005).

Na maioria dos sistemas de cultura de tecidos, esse padrão de desenvolvimento é determinado principalmente pela utilização de reguladores de crescimento, que reproduzem o que ocorre naturalmente nas plantas e exercem sua ação por reconhecimento de receptores específicos, presentes em células responsivas, que traduzem os sinais hormonais em eventos bioquímicos e fisiológicos na planta (Jiménez, 2001).

Outro fator importante que influencia a capacidade das células se desdiferenciarem e rediferenciarem é a presença de componentes orgânicos e inorgânicos dos meios de cultura (Wareing \& Phillips, 1982). Historicamente, diversas formulações de meio de cultura têm sido empregadas no cultivo in vitro, as quais diferem entre si basicamente em relação à composição e concentração destes componentes. Diante disso, diversos estudos de nutrição mineral foram realizados para o desenvolvimento de soluções nutritivas que atendessem às necessidades vitais das plantas, estudos esses que culminaram na formulação da solução nutritiva de Knop. A partir dessa solução Gautheret (1934) formulou os macronutrientes do meio nutritivo. Em paralelo, White (1932; 1933; 1934; 1938) desenvolveu uma composição diferente de macronutrientes com base na solução nutritiva de Uspenski \& Uspenskaia (1925), por meio de uma série de estudos com cultura de raízes de trigo e de tomate. Durante muito tempo, o meio White foi utilizado como meio básico para a cultura de uma grande variedade de tecidos de diversas espécies (Torres et al., 1998).

Posteriormente, modificações nesse meio nutritivo visando otimizar 0 crescimento de calos na cultura in vitro foram realizadas. Essas mudanças envolveram, principalmente, o aumento das concentrações dos sais em geral, uma diminuição na 
concentração de sódio e o acréscimo de nitrogênio, na forma de amônio, para complementar o nitrato, originando o meio de MS, que é assim chamado em referência aos seus autores, Murashige \& Skoog (1962). Esse meio foi desenvolvido a partir de suplementações de constituintes orgânicos e inorgânicos do meio de White em culturas de Nicotiana tabacum por Murashige \& Skoog (1962).

Diante do aumento das concentrações dos sais no meio nutritivo de MS, principalmente amônio e nitrato, um maior crescimento de células e tecidos de plantas foi alcançado para a maioria das espécies vegetais, tornando a formulação de MS a mais utilizada em trabalhos com cultura de tecidos de plantas (Thorpe, 2007).

O desenvolvimento vegetal também é fortemente influenciado pela síntese de hormônios nas plantas. Os hosmônios são biomoléculas produzidas pelas plantas, capazes de induzir respostas fisiológicas específicas, como por exemplo, a indução de raízes, a formação de brotos, o alongamento de entrenós, entre outras (Woodward \& Bartel, 2005). Além da presença de hormônios endógenos nos tecidos vegetais, o cultivo in vitro é intensamente influenciado pela utilização de reguladores de crescimento, que são moléculas sintéticas com efeito semelhante ao dos hormônios vegetais. Na cultura de tecidos, os hormônios em suas formas naturais ou sintéticas, mais utilizados, são as auxinas e as citocininas (Chen et al., 2014).

$\mathrm{Na}$ cultura de tecidos, as auxinas são frequentemente usadas visando à indução de calos a partir de um explantes ou no enraizamento de brotos, uma vez que, são um dos grupos de hormônios responsáveis pelo crescimento celular (Cueva-Agila et al., 2016). As auxinas mais comumentes utilizadas são: o ácido indolbutírico (AIB), o ácido naftalenoacético (ANA), o 2,4-diclorofenoxiacético (2,4-D) e o ácido 4-amino-3,5,6tricloro-picolínico (Picloram) (Pandolfini et al., 2007).

Além dos reguladores de crescimento e dos compostos orgânicos e inorgânicos, as plantas cultivadas in vitro também requerem a adição de carboidratos, como a sacarose, para suprir suas necessidades metabólicas. Estes são importantes tanto pela geração de energia, como por servirem como fontes de esqueletos carbônicos para os vários processos de biosintéticos implicados na diferenciação e crescimento de suas células (Leifert et al., 1995).

A principal vantagem da propagação vegetativa in vitro se constitui na possibilidade de produzir um elevado número de plantas em um curto espaço de tempo e ocupando uma área física bastante reduzida, se comparada com os métodos convencionais de multiplicação (Soh et al., 2011). Outra vantagem nesse processo é a 
retirada dos explantes sem a destruição da planta matriz, um fator de considerável importância em se tratando de plantas raras ou exemplares únicos (Thuzar et al., 2011).

\subsection{Embriogênese somática}

A micropropagação via embriogênese somática é uma técnica da cultura de tecidos definida como o processo pelo qual células somáticas desenvolvem-se por meio de diferentes estádios embriogênicos, formando uma estrutura bipolar, chamada embrião somático, que ao final do processo de diferenciação dá origem a uma planta (Reinert, 1958; Williams \& Maheswaran, 1986). Esse fato pode possibilitar a produção clonal de um elevado número de plantas em um curto espaço de tempo, ocupando uma área física bastante reduzida, se comparada com os métodos convencionais de multiplicação. A técnica permite ainda a retirada de propágulos sem a destruição da planta matriz, um fator de considerável importância em se tratando da raridade de algumas plantas, bem como, propagação acelerada de clones superiores e a manutenção de híbridos interespecíficos (Anami et al., 2010). Além disso, também pode servir como sistema modelo para estudar os eventos moleculares, citológicos, fisiológicos e de desenvolvimento envolvidos no processo embriogênico das plantas (Dodeman et al., 1997).

A embriogênese somática in vitro apresenta dois padrões básicos de desenvolvimento de embriões somáticos (Sharp et al., 1980). Um padrão é a embriogênese somática direta (ESD), na qual os embriões somáticos originam-se diretamente de tecidos matrizes, sem a formação de estádios intermediários de calos, realizada em mais de $60 \%$ dos protocolos (Gaj, 2004). Já na embriogênese indireta (ESI), os embriões somáticos se formam a partir de um calo, que apresenta células em diferentes estádios de diferenciação. Em ambos os padrões, o embrião somático segue a mesma sequência de desenvolvimento do zigótico, ou seja, a passagem pelos estádios globular, cordiforme, torpedo e cotiledonar (Jayanthi et al., 2011; Marbun et al., 2015).

A ESI, na maioria das espécies vegetais, é a metodologia mais promissora, devido á possibilidade de obtenção de maior número de propágulos em comparação a ESD, além de, permitir a sincronização da produção, bem como a automação das etapas do cultivo. No entanto, ainda precisa ser otimizada e adaptada para a realidade 
encontrada na produção de mudas em larga escala. Basicamente, essa metodologia é composta de quatro etapas principais: indução e multiplicação de calos, diferenciação e regeneração de embriões somáticos em plantas (Touchet et al., 1991; Kanchanapoom \& Domyoas, 1999; Te-chato et al., 2002; Tarmizi et al., 2008; Silva et al., 2012).

A indução da embriogênese somática é o desencadeamento de um processo morfogenético, devido a um estímulo físico e/ou químico sofrido pelo explante, sendo a etapa mais crítica para o estabelecimento das culturas embriogênicas in vitro (Fehér et al., 2002). Segundo Merkle et al. (1995), a indução da embriogênese somática está relacionada a alterações no padrão de expressão gênica dos explantes, com reprogramação das células que estão envolvidas no processo embriogênico. Entretanto, o potencial embriogênico não é somente determinado geneticamente, mas também é influenciado pela composição dos meios de cultura e pelas características dos explantes (Elmeer, 2013).

Após a indução de calos primários e embriogênicos, é realizada a multiplicação das culturas embriogênicas, que consiste geralmente da redução nos níveis dos reguladores de crescimento do meio de cultura. Essa redução permite ciclos repetitivos de divisão celular e o controle dos processos de diferenciação (Tarmizi et al., 2004; Choi et al., 2008; Marbun et al., 2015). É nessa fase que geralmente suspensões celulares são estabelecidas (Gorret et al., 2004).

Após a etapa de multiplicação, é realizada a fase de diferenciação celular, também conhecida como fase de diferenciação de embriões somáticos, que consiste em fornecer estímulos fisiológicos, bioquímicos e ambientais que interrompam os ciclos repetitivos de divisão celular da fase anterior e promovam o início da diferenciação e obtenção de embriões somáticos. Nessa etapa, alguns fatores exercem grande influência no desempenho da diferenciação de embriões somáticos, destacando-se principalmente as composições e as concentrações dos reguladores de crescimento utilizados e o aumento da osmolaridade no meio de cultura, sabendo-se que os mesmos podem variar de acordo com a espécie (Touchet et al., 1991; Silva et al., 2012; Tarmizi et al., 2008; Marbun et al., 2015).

Após a fase de diferenciação, é realizada a regeneração de plântulas a partir de embriões somáticos maduros. Nos protocolos de embriogênese somática, a germinação dos embriões é usualmente realizada em meios de cultura livre de reguladores de crescimento (Gomes et al., 2016). 
A embriogênese somática in vitro também é influenciada pelo sistema de cultivo utilizado nos diferentes estádios embriogênicos. Calos primários e embriogênicos de diversas espécies vegetais vêm sendo cultivados com sucesso utilizando meios nutritivos líquidos em frascos de Erlenmeyer sob agitação (Boxtel \& Berthouly, 1996), em biorreatores de imersão contínua (Noriega \& Sondahl, 1993) e biorreatores de imersão temporária (Teisson et al., 1995). Essas tecnologias têm sido amplamente testadas na produção massal de mudas, a fim de otimizar protocolos preestabelecidos, solucionar certos problemas enfrentados, além de permitir semi-automação do processo e diminuir os custos de produção, uma vez que gastos com agentes gelificantes são reduzidos (Tarmizi et al., 2004; Tarmizi et al., 2008; Gomes et al., 2016; Marbum et al., 2015).

O processo de aclimatização representa uma etapa importante na cultura de tecidos, sendo um fator limitante na micropropagação. Este processo consiste na retirada e transferência das plântulas do meio de cultivo in vitro para outro tipo de substrato e ambiente, promovendo uma adaptação gradativa da planta ao novo ambiente (Chandra et al. 2010; Gomes et al., 2015). Esse processo é crucial para a obtenção de mudas de qualidade provenientes da cultura de tecidos.

Em palmeiras, alguns protocolos de embriogênese somática já foram desenvolvidos utilizando-se como explantes embriões zigóticos (Ledo et al., 2002; Thuzar et al., 2011; Heringer et al., 2014; Luis \& Scherwinski-Pereira, 2014), folhas jovens e inflorescências imaturas (Schwendiman et al., 1988; Teixeira et al., 1994; Guerra \& Handro, 1998, Karun et al., 2004; Scherwinski-Pereira et al., 2010), além de ovários não fertilizados (Pereira et al., 2007).

Em dendezeiros, a produção de mudas por embriogênese somática via folhas jovens, inflorescências imaturas e embriões zigóticos de frutos maduros e imaturos, também é descrita por diversos autores (Rabéchault \& Martin, 1976; Corley et al., 1977; Pannetier et al., 1981; Duval et al., 1988; Touchet et al., 1991; Teixeira et al., 1993; Rival et al., 1997; Choi et al., 2008; Konan et al., 2010; Scherwinski-Pereira et al., 2010; Thuzar et al., 2011; Balzon et al., 2013).

Apesar da utilização do embrião zigótico como explante inicial já estar bem documentado, os estudos com folhas imaturas necessitam de maior aprofundamento. O uso de folhas imaturas como explante inicial é promissor, uma vez que permite a clonagem das plantas adultas, sem a influência da segregação do material genético realizado após os cruzamentos parentais. Diversos trabalhos são encontrados na 
literatura com embriogênese somática em palmeiras. Teixeira et al. (1995) estabeleceram um protocolo de suspensões celulares em dendezeiro utilizando embriões zigóticos maduros e imaturos como fonte de explantes. Os meios de cultura para a indução de calo foi o de MS e o Y3, contendo diferentes tratamentos de fitorreguladores (475-500 $\mu \mathrm{M}$ de 2,4-D e $250 \mu \mathrm{M}$ de Picloram), e suplementado com 0,3\% de carvão ativado. Após esse período, calos embriogênicos friáveis e calos globulares foram diferenciados em todos os tratamentos. Culturas de suspensão das linhagens celulares foram estabelecidas em meio de cultura $Y 3$, adicionado com $10 \mu \mathrm{M}$ de 2,4-D. Nesta fase, a diferenciação dos embriões somáticos só foi observada em suspensões de células oriundas de calo embriogênico friável. As plantas oriundas da germinação dos embriões somáticos cresceram satisfatoriamente em condições de estufa.

Kanchanapoom \& Domyoas (1999) utilizaram embriões zigóticos de dendê para estabelecer um protocolo de embriogênese somática. O material vegetal foi inoculado em meio de cultura Y3 suplementando com $2 \mathrm{mg} \cdot \mathrm{L}^{-1}$ de 2,4-D para a fase de indução. Após oito semanas da inoculação, a formação de calos foi iniciada. Em seguida, para a diferenciação dos embriões somáticos e regeneração de plantas, dois meios de cultura sucessivos foram empregados. O primeiro meio foi o de MS isento de reguladores de crescimento, mas com $0,05 \%$ de carvão ativado, e o segundo, continha $0,1 \mathrm{mg} \cdot \mathrm{L}^{-1} \mathrm{de}$ BAP e 2,5 mg. $\mathrm{L}^{-1}$ de 2,4-D. As análises histológicas evidenciaram que os calos tiveram origem a partir das células da subepiderme dos explantes.

O protocolo desenvolvido por Touchet et al. (1991) utilizou suspensão celular de calos embriogênicos obtidos a partir de segmentos de folhas imaturas de dendezeiro. $O$ meio de cultura para indução da embriogênese somática foi o de MS adicionado de 30 mg.L $\mathrm{L}^{-1}$ de BAP, 1,0 g. $\mathrm{L}^{-1}$ de carvão ativado e quatro concentrações de 2,4-D. As concentrações de 80 e $100 \mathrm{mg} \cdot \mathrm{L}^{-1}$ de 2,4-D foram consideradas as mais efetivas para produção de células embriogênicas com características pró-embrionárias. Para a proliferação, os meios de cultura continham 2,4-D nas concentrações de 25, 50 e 100 $\mathrm{mg} \cdot \mathrm{L}^{-1}$, sendo que a concentração de $100 \mathrm{mg} \cdot \mathrm{L}^{-1}$ manteve o potencial embriogênico, após 18 semanas de cultivo. O meio de cultura empregado na regeneração foi o de MS sem reguladores de crescimento, dando origem a plantas que depois de enraizadas foram transferidas para casa de vegetação.

Alguns protocolos já foram descritos para palmeiras utilizando como explante embriões zigóticos e inflorescências imaturas. Texeira et al. (1993), trabalhando com 
embriões zigóticos de dendê, observaram que na fase de indução, os explantes começaram a formar tecidos embriogênicos após duas semanas em meio de cultura suplementado com $500 \mu \mathrm{M}$ de 2,4-D. Guerra \& Handro (1998) utilizaram embriões zigóticos e inflorescência imatura de Euterpe edulis como fonte de explante, submetidos a $100 \mathrm{mg} \cdot \mathrm{L}^{-1}$ de 2,4-D. Esses autores observaram o surgimento de estruturas globulares que correspondiam a embriões somáticos no estágio globular, conferindo um modelo direto.

$\mathrm{Na}$ fase de indução também são observados bons resultados com folhas jovens de dendê. Besse et al. (1992) obtiveram formação de calos nodulares compactos e calos friáveis, quando as folhas jovens foram submetidas a concentrações elevadas de 2,4-D.

A utilização do Picloram também é bastante citada na indução e obtenção de calos embriogênicos (Titon et al., 2007; Scherwinski-Pereira et al., 2010). Huong et al. (1999) observaram que altas concentrações de Picloram no meio de cultura foi o que promoveu a indução de calos embriogênicos nodulares em Phoenix canariensis.

Alguns protocolos já foram descritos para palmeiras, nos quais houve a regeneração de plantas por meio de suspensões de células embriogênicas, oriundas de calos obtidos a partir de folhas de dendê (Touchet et al., 1991; Tarmizi et al., 2004). Já Teixeira et al. (1995) obtiveram calos embriogênicos a partir de embriões zigóticos de dendê, submetidos a $250 \mu \mathrm{M}$ de Picloram e estabeleceram suspensões embriogênicas em meio de cultura $Y 3$ suplementando com $10 \mu \mathrm{M}$ de 2,4-D.

Kanchanapoom \& Domyoas (1999) utilizaram dois meios de cultura sucessivos para a diferenciação dos embriões somáticos e regeneração de plantas. O primeiro meio foi o de MS isento de reguladores de crescimento, mas com $0,05 \%$ de carvão ativado, e o segundo, continha $0,1 \mathrm{mg} \cdot \mathrm{L}^{-1}$ de BAP e $2,5 \mathrm{mg} \cdot \mathrm{L}^{-1}$ de 2,4-D. Já no protocolo desenvolvido por Guerra \& Handro (1998) em E. edulis, os calos embriogênicos foram maturados em meio de cultura suplementando com $2,5 \mathrm{mg} \cdot \mathrm{L}^{-1}$ de 2-iP e 0,1 mg. L $^{-1}$ de ANA.

Ledo et al. (2002) observaram que o meio de cultura suplementando com ANA e 2-iP foi eficiente para a multiplicação e manutenção de calos embriogênicos de Euterpe oleracea Mart., além de promover a progressão dos calos em estágios mais avançados dos embriões somáticos, os autores observaram um desenvolvimento embriogênico não sincronizado para esta espécie. 
Após obtenção dos embriões somáticos maduros, a germinação é usualmente realizada em meio de cultura livre de reguladores de crescimento (Komatsuda et al., 1992; Fernández- Guijarro et al., 1995). Hilae \& Te-chato (2005) estudaram fontes de carbono na germinação de embriões somáticos de dendê e verificaram que a maior porcentagem de germinação foi obtida em meio de MS suplementado com 0,2 M de sorbitol. Esses autores também observaram que a alta concentração de sacarose ou sorbitol promoveram a formação de raízes.

\subsection{Estudos anatômicos}

Em várias espécies vegetais, o entendimento dos mecanismos que regulam as diferentes etapas desse processo ainda é bastante limitado (Apostolo et al., 2005). Diante disso, a realização de estudos anatômicos durante a embriogênese somática pode proporcionar uma grande quantidade de informação, incluindo àquelas associadas à formação de mudas anômalas, à indução da competência embriogênica e à mobilização de reservas nas fases de maturação e de regeneração dos embriões somáticos, colaborando dessa forma para a otimização dos protocolos de micropropagação já existentes (Adam et al., 2005; Ribeiro et al., 2012; Thomas \& Boura, 2015). Acrescenta-se, ainda, que são poucos os estudos que associam avaliações morfohistológicas para compreender os processos in vitro e aperfeiçoar os protocolos de embriogênese somática (Apostolo \& Llorente, 2000; Steinmacher et al., 2007). Tais aspectos são fundamentais no aprimoramento de protocolos existentes e no estabelecimento de metodologias de sistemas de regeneração in vitro mais eficientes.

O emprego das técnicas de análise anatômica permite o detalhamento de eventos que ocorrem quando espécies vegetais são cultivadas in vitro. Estudos histológicos podem ser realizados para a verificação e confirmação do desenvolvimento das gemas adventícias (organogênese) ou de embriões somáticos (embriogênese somática) e a definição da origem direta ou indireta (Rodrigues et al., 2004).

Caracteres morfológicos e anatômicos, tanto vegetativos quanto reprodutivos, estão relacionados com determinadas condições ambientais, embora a relação entre esses caracteres adaptativos e as condições ambientais, em muitos casos, seja difícil de estabelecer (Ehrendorfer, 1973). No cultivo in vitro, as plantas podem apresentar características peculiares como abundância de espaços intercelulares, sistema 
vascular pouco desenvolvido, reduzida capacidade de sustentação (esclerênquima e colênquima) e outros tipos de alterações (Campostrini \& Otoni, 1996).

O estudo do desenvolvimento de células ou grupos de células por técnicas histológicas tem se mostrado útil para o entendimento da embriogênese em várias espécies vegetais. Em Hevea brasiliensis, o tempo adequado de subcultivos foi determinado por meio de análises histológicas. Avaliando o potencial embriogênico do calo durante o seu desenvolvimento, esses autores puderam adaptar o tempo de subcultivo para otimizar a formação de embriões. Eles verificaram que células préembriogênicas foram observada em calos com 15 a 30 dias de cultivo e que essas células apenas se tornaram tipicamente embriogênicas após o cultivo em meio fresco, uma vez que sem a renovação dos meios as células não apresentaram potencial para formação de embriões somáticos (Michaux-Fèrriere \& Carron, 1996). Ao se utilizar embriões zigóticos de Cocos nucifera como fonte de embriogênese somática, verificouse que o processo tem origem principalmente na plúmula (Chan et al., 1998), e o cultivo desta estrutura vem potencializando os protocolos de embriogênese dessa espécie (Pérez-Nuñez et al., 2006).

As alterações histológicas associadas com a posição e a atividade das células competentes, durante a embriogênese somática, têm sido bastante estudadas. A iniciação do desenvolvimento da embriogênese somática do dendezeiro ( $E$. guineensis) a partir de folhas jovens revelou pela análise morfológica e anatômica, acentuada divisão nas células perivasculares, sendo o centro de origem das células meristemáticas, seguido da formação do calo (Schwendiman et al., 1988).

Estudos histológicos das culturas embriogênicas oriundas de embriões zigóticos de $E$. edulis evidenciaram que a origem das massas meristemáticas foram a partir de tecidos da subepiderme (Guerra \& Handro, 1998). Esses mesmos autores descreveram os proembriões e os embriões nos diferentes estágios de maturação. Neste sentido, o acompanhamento e a identificação das estruturas presentes nos diferentes estágios durante a embriogênese somática, por meio de estudos anatômicos parecem necessários para melhor entendimento dos processos morfogênicos e maximização de protocolos eficientes de clonagem da espécie. 


\subsection{Análises bioquímicas}

Segundo Barendse \& Peeters (1995), em todos os sistemas vegetais os processos de desenvolvimento são resultado de um complexo controle espacial e temporal, onde vários hormônios atuam na regulação da expressão de múltiplos genes. Esses hormônios vegetais são denominados reguladores químicos de ocorrência natural que produzem respostas metabólicas, fisiológicas, sendo efetivos em pequenas quantidades, e provavelmente, os mais importantes mediadores na transdução de sinais (Taiz \& Zeiger, 2009). No entanto, além dos reguladores de crescimento outros compostos estão envolvidos nos processos de desenvolvimento vegetal, como os carboidratos, os lipídios, os aminoácidos e as proteínas (Guerra et al., 1999).

Os carboidratos constituem um grupo de compostos que inclui açúcares e outras moléculas mais complexas constituídas por subunidades de açúcares mais simples, cuja principal função é o fornecimento de energia química aos processos celulares (Brum et al., 1994). De acordo com Moghaddam \& Ende (2012), existem outras funções atribuídas aos carboidratos, tais como, os amidos, que são fontes de reserva, a celulose e a hemicelulose que possibilitam a sustentação, entre outras mais específicas.

Dentro do desenvolvimento embriogênico, os carboidratos desempenham importante papel no processo de formação do embrião, atuando como fonte de energia, esqueletos carbônicos e/ou como sinalizadores. Na maioria das plantas, no processo de formação do embrião, a glucose e a frutose estão presentes na fase inicial de desenvolvimento embrionário, e diminuem gradualmente, contrariamente à sacarose que aumenta na fase final do desenvolvimento embrionário (Focks \& Benning, 1998). Já na fase de maturação dos embriões ocorre à síntese tanto de proteínas quanto de carboidratos (Baud et al., 2002).

Segundo pesquisas, durante o desenvolvimento do embrião somático, observase que os carboidratos atuam como fonte de energia metabólica, como fonte de compostos de reserva e como fonte de esqueletos carbônicos e, juntamente com outras substâncias, também atuam para tornar os embriões quiescentes e tolerantes a dessecação, possibilitando assim, a sua regeneração (Lipavská \& Konrádová, 2004).

Um excelente método de estudo da embriogênese somática é a comparação do metabolismo dessa rota de desenvolvimento com o metabolismo da embriogênese zigótica, uma vez que a embriogênese zigótica apresenta-se como um sistema modelo 
de formação de embrião. Na comparação das duas rotas, observa-se que a relação hexoses/sacarose pode influenciar a divisão e diferenciação celular no início do desenvolvimento de embriões somáticos e zigóticos, enquanto que o amido parece estar envolvido na separação e armazenagem de carboidratos (Pescador et al., 2008).

Os lipídios formam, juntamente com os carboidratos e as proteínas, as substâncias mais frequentemente encontradas na natureza, tanto nos animais quanto nos vegetais. Comparativamente aos dois últimos, os lipídios representam a forma mais reduzida do carbono, podendo gerar, na oxidação de um grama, três vezes mais energia do que na oxidação da mesma quantidade de amido (Taiz \& Zeiger, 2009).

Lipídios são constituintes essenciais nas células das plantas, sendo os triglicerídeos mais eficientes como forma de armazenamento de carbono reduzido, enquanto os fosfolipídios são constituintes de membranas celulares de planta ou mensageiros secundários nos processos fisiológicos (Blanckaert et al., 2000). Os triglicerídeos são constituídos por um resíduo de glicerol e três moléculas de ácidos graxos, ocupando uma posição de destaque como principal reserva nas sementes e embriões. Durante o processo de maturação do embrião, bem como na germinação de sementes, os ésteres são hidrolisados e os ácidos graxos são utilizados na produção de ATP e outras substâncias (Ohlrogge \& Browse, 1995).

Os lipídios estão envolvidos no desenvolvimento, crescimento e senescência de plantas (Miquel \& Browse, 1995). O entendimento das suas funções no desenvolvimento vegetal tem avançado pelos estudos em mutantes de Arabidopsis, por exemplo, nos quais um incremento nos níveis de ácido esteárico como lipídio de membrana no mutante fab2 causou dramática diminuição no tamanho das plantas desta espécie (Leightner et al., 1994).

Nas células, os ácidos graxos constituintes dos lipídios apresentam-se em uma determinada concentração dependente da estabilidade e da fluidez da membrana celular (Moore, 1982). Pouco se conhece a respeito das modificações e da composição dos lipídios de reserva durante a embriogênese zigótica das plantas (ReidiboymTalleux \& March, 1999). Entretando, sabe-se que na embriogênese zigótica, ocorre a formação de um eixo portador de meristemas caulinar e radicular, acompanhada pela formação dos cotilédones, esses últimos mais de perto associados à síntese e estocagem de substâncias de reserva, como os lipídios (Dodeman et al., 1997). 
Já os aminoácidos, são formados pela incorporação do nitrogênio absorvido aos compostos de carbono como amino-grupos e são compostos básicos para a biossíntese de proteínas, ácidos nucléicos e substâncias nitrogenadas do metabolismo secundário. Neste caso, atuam como precursores de hormônios vegetais e de compostos envolvidos na defesa vegetal (Malavolta, 1997; Larcher, 2000).

Estudos vêm demonstrando que a concentração de aminoácidos envolvidos na embriogênese somática, principalmente a de prolina, aumentam e diminuem rapidamente durante as diferentes etapas do processo. Dessa forma pode-se perceber que esses compostos são intimamente relacionados a essa rota de desenvolvimento vegetal (Sen et al., 2002, Booz et al., 2009, Kumar \& Kumari, 2011). Diante disso, a fim de beneficiar o desenvolvimento de culturas embriogênicas, pesquisadores estão frequentemente suplementando os meios de cultura com fontes de aminoácidos (Scherwinski-Pereira et al., 2010; Silva et al., 2012).

Conforme mencionado anteriormente, as proteínas são polímeros, moléculas complexas compostas por um determinado número de subunidades designadas aminoácidos. Sendo as proteínas moléculas complexas, essas são formadas por várias centenas de aminoácidos. O número das diferentes sequências de aminoácidos e, portanto, a possível variedade de moléculas de proteínas mostra-se enorme (Raven et al., 1996). De acordo com Brum et al. (1994), cada proteína é formada por uma sequência única de aminoácidos, o que determina sua função dentro do ambiente celular.

O metabolismo de proteínas é extremamente ativo e dependente do tipo e idade do órgão. Órgãos e tecidos em crescimento ou de estoque são caracterizados pela síntese intensa de proteínas, entretanto, em folhas senescentes ocorre a degradação das mesmas. A síntese de proteínas é caracterizada pela alta e rápida capacidade de adaptação molecular, funcional e fisiológica, em relação ao meio (Larcher, 2000). 
As proteínas também desempenham um importante papel na embriogênese somática. Segundo Wise \& Tunnacliffe (2004), no processo germinativo ou no processo de diferenciação, no caso do embrião somático, as proteínas de reserva armazenadas durante o processo embriogênico são então degradadas, e os aminoácidos que as compõem são hidrolisados, liberando grandes quantidades de compostos a serem utilizados no crescimento da plântula.

Durante o desenvolvimento embriogênico, observa-se um aumento na concentração de proteínas totais em função, não só, da síntese de proteínas de reserva, mas também do acúmulo de proteínas associadas ao estresse e outras classes de proteínas, como aquelas relacionadas à respiração (glicólise, ciclo de Krebs e fosforilação oxidativa), à biossíntese de carboidratos e ao metabolismo de aminoácidos (Aberlenc-Bertossi et al., 2008; Sghaier-Hammami et al., 2009; Cangahuala-Inocente et al., 2009). O aumento da concentração de proteínas, durante a embriogênese, resulta também da síntese de proteínas LEA (late embryogenesis abundant), as quais irão atuar na proteção dos embriões contra a desidratação (Cangahuala-Inocente et al., 2009). 


\section{OBJETIVOS}

\subsection{Objetivo Geral}

- Otimizar as fases de indução e multiplicação de linhagens embriogênicas originárias de folhas jovens de plantas adultas de dendezeiro (Elaeis guineensis Jacq.) e analisar morfoanatômicamente e bioquímicamente as etapas envolvidas no processo.

\subsection{Objetivos Específicos}

- Avaliar respostas morfogênicas in vitro de folhas imaturas de diferentes genótipos de dendezeiros;

- Definir combinações de reguladores de crescimento e condições de cultivo para a melhor indução e multiplicação das linhagens embriogênicas;

- Caracterizar morfoanatomicamente explantes foliares, calos primários e calos embriogênicos;

- Caracterizar o metabolismo dos açúcares, amido, ácidos graxos, aminoácidos e proteínas nos diferentes estádios das etapas de indução e multiplicação de calos da embriogênese somática; 


\section{REFERÊNCIAS BIBLIOGRÁFICAS}

ABDULLAH, R.; ZAINAL, A.; HENG, W. Y.; LI, L. C.; BENG, Y. C.; PHING, L. M.; SIRAJUDDIN, S. A.; PING, W. Y. S.; JOSEPH, J. L.; JUSOH, S. A. Immature embryo: A useful tool for oil palm (Elaeis guineensis Jacq.) genetic transformation studies. Electronic Journal of Biotechnology, v.8, p.24-34, 2005.

ABERLENC-BERTOSSI, F.; CHABRILLANGE, N.; DUVAL, Y.; TREGEAR, J. Contrasting globulin and cysteine proteinase gene expression patterns reveal fundamental developmental differences between zygotic and somatic embryos of oil palm. Tree Physiology, v.28, p.1157-1167, 2008.

ABRAPALMA. Associação Brasileira de Produtores de Óleo de Palma. A palma no Brasil e no mundo. Disponível em: < http://www.abrapalma.org/pt/a-palma-no-brasil-eno-mundo >. Acesso em: 04 de agosto de 2016.

ADAM, H.; JOUANNIC, S.; ESCOUTE, J.; DUVAL, Y.; VERDEIL, J.; TREGEAR, J. W. Reproductive develomental complexity in the african oil palm (Elaeis guineensis, Arecaceae). American Journal of Botany, v.92, p.1836-1852, 2005.

ADAM, H.; COLLIN, M.; RICHAUD, F.; BEULE, T.; CROS, D.; OMORE, A.; NODICHAO, L.; NOUY, B.; TREGEAR, J. W. Environmental regulation of sex determination in oil palm: current knowledge and insights from other species. Annals of Botany, v.108, p.1529-1537, 2011.

AMMIRATO, P. V. The regulation of somatic embryo development in plant cell cultures: suspension culture techniques and hormone requirements. Nature Biotechnology, v.1, p.68-73, 1983.

ANAMI, S. E.; MGUTU, A. J.; TARACHA, C.; COUSSENS, G.; KARIMI, M.; HILSON, P. Somatic embryogenesis and plant regeneration of tropical maize genotypes. Plant Cell, Tissue and Organ Culture, v.102, p.285-295, 2010.

APOSTOLO, N. M.; LLORENTE, B. E. Anatomy of normal and hyperhydric leaves and shoots in vitro grown Simmondsia chinensis (Link) Schn. In Vitro Cellular \& Developmental Biology - Plant, v.36, p.243-249, 2000.

APOSTOLO, N. M.; BRUTTI, C. B.; LLORENTE, B. E. Leaf anatomy of Cynara scolymus L. in successive micropropagation stages. In Vitro Cellular \& Developmental Biology - Plant, v.41, p.307-313, 2005.

BALZON, T. A.; LUIZ, Z. G.; SCHERWINSKI-PEREIRA, J. E. New approaches to improve the efficiency of somatic embryogenesis in oil palm (Elaeis guineensis Jacq.) from mature zygotic embryos. In Vitro Cellular and Developmental Biology - Plant, v.49, p.41-50, 2013.

BARCELOS, E.; RIOS, S. A.; CUNHA, R. N. V.; LOPES, R.; MOTOIKE, S. Y.; BABIYCHUK, E.; SKIRYCZ, A.; KUSHNIR, S. Oil palm natural diversity and the potential for yield improvement. Frontiers in Plant Science, v. 6, p.190, 2015. 
BARENDSE, G. W. N.; PEETERS, T. J. M. Multiple hormonal control in plants. Acta Botanica, v.44, p.03-17, 1995.

BARI, R.; JONES, J. D. G. Role of plant hormones in plant defence responses. Plant Molecular Biology, v.69, p.473-488, 2009.

BAUD, S.; BOUTIN, J. P.; MIQUEL, M.; LEPINIEC, L.; ROCHAT, C. An integrated overview of seed development in Arabidopsis thaliana ecotype WS. Plant Physiology and Biochemestry, p.151-160, 2002.

BESSE, I.; VERDEIL, J. L.; DUVAL, Y.; SOTTA, B.; MALDINEY, R. e MIGINIAC, E. Oil Palm (Elaeis guineensis Jacq.) Clonal Fidelity: Endogenous Cytokinins and Indoleacetic Acid in Embryogenic Callus Cultures. Journal of Experimental Botany, v. 43, p. 983989, 1992.

BLANCKAERT, A.; BELINGHERI, L.; VASSEUR, J.; HILBERT, J.L. Changes in lipid composition during somatic embryogenesis in leaves of Cichorium. Plant Science, v.157, p.165-172, 2000.

BODDEY, R. M. Green energy from sugar cane. Chemistry and Industry, v.12, p.355358, 1993.

BOOZ, M. R.; KERBAUY, G. B.; GUERRA, M. P.; PESCADOR, R. The role of $\mathrm{Y}^{-}$ aminobutyric acid (Gaba) in somatic embryogenesis of Acca sellowiana Berg. (Myrtaceae). Brazilian Society of Plant Physiology, v.21, p.271-280, 2009.

BOXTEL, J.; BERTHOULY, M. High frequency somatic embryogenesis from coffee leaves. Factors influencing embryogenesis, and subsequent proliferation e regeneration in liquid medium. Plant Cell, Tissue ang Organ Culture, v.44, p.7-17, 1996.

BRUM, G.; McKANE, L.; KARP, G. Biology: exploring life. 2.ed. New York: John Wiley, 1030p., 1994.

CAMPOSTRINI, E.; OTONI, W. C. Aclimatização de plantas: abordagens recentes. Brasília: Embrapa-CNPH, ABCTP notícias, v.25, p.12, 1996.

CANGAHUALA-INOCENTE, G. C.; STEINER, N.; MALDONADO, S. B.GUERRA, M. P. Patterns of protein and carboydrate accumulation during somatic embryogenesis of Acca sellowiana. Pesquisa Agropecuária Brasileira, v.44, p.217-224, 2009.

CARVALHO, A. R. V. de; BALDANI, V. L. D.; REIS, V. M. O Dendê (Elaeis guineensis Jacq.). Seropédica: Embrapa Agrobiologia, Documentos, v.138, p. 252001.

CHAN, J. L.; SAÉNZ, L.; TALAVERA, C.; HORNUNG, R., ROBERT, M. and OROPEZA, C. Regeneration of coconut (Cocos nucifera L.) from plumule explants through somatic embryogenesis. Plant Cell Reports, v.17, p.515-521, 1998.

CHANDRA, S.; BANDOPADHYAY, R.; KUMAR, V.; CHANDRA, R. Acclimatization of tissue cultured plantlets: from laboratory to land. Biotechnology Letters, v.32, p.11991205, 2010. 
CHANPRASERT, W.; MYINT, T.; SRIKUL, S.; WONGSRI, O. Effects of neonicotinoid and method of breaking dormancy on seed germination and seedling vigour of oil palm (Elaeis guineensis Jacq.). Journal of Oil Palm Research, v.24, p.1227-1234, 2012.

CHEN, J. R.; WU, L.; HU, B. W.; YI, X.; LIU, R.; DENG, Z. N.; XIONG, X. Y. The influence of plant growth regulators and light quality on somatic embryogenesis in China Rose (Rosa chinensis Jacq.). Journal of Plant Growth Regulation, v.33, p.295-304, 2014.

CHOI, D. S.; ANDRADE, M. H. C.; WILLIS, L. B.; CHO, C. W.; SCHOENHEIT, J.; BOCCAZZI, P.; SAMBANTHANMURTHI, R.; SINSKEY, A. J.; RHA, C. K. Effect of agitation and aeration of yield optimization of oil palm suspension culture. Journal of Palm Oil Research , v.1, p.23-34, 2008.

CORLEY, R. V. H.; BARRET, J. N.; JONES, L. H. Vegetative propagation of oil palm via tissue culture. Oil Palm News, v.22, p.2-7, 1977.

CUEVA-AGILA, A. Y.; MEDINA, J.; CONCIA, L.; CELLA, R. Effects of plant growth regulator, auxin polar transport inhibitors on somatic embryogenesis and CmSERK gene expression in Cattleya maxima (Lindl.). In Somatic Embryogenesis in Ornamentals and Its Applications, p. 255-267, 2016.

DESAI, S. R.; VENKATACHALAM, P. Emission characteristics of pongamia (Pongamia pinnata L.) biodiesel and its blends with petro diesel. Engineering and Technology in India, v.3, p.102-106, 2012.

DÍAZ-PÉREZ, J. C.; SHACKEL, K. A.; SUTTER, E. G. Effects of in vitro formed roots and acclimatization on water status and gas exchange of tissue-cultured apple shoots. Journal of American Society for Horticulture Science, Alexandria, v.120, p.435-440, 1995.

DODEMAN, V. L.; DUCREX, G.; KREIS, M. Zygotic embryogenesis versus somatic embryogenesis. Journal Experimental Botany, v.48, p.1493-1509, 1997.

DURAND-GASSELIN, T.; GUEN, V.; KONAN, K.; DUVAL, Y. Oil palm (Elaeis guineensis Jacq.) plantations in Ivory Coast obtained through in vitro culture. First results. Oléagineux, v.45, p.1-11, 1990.

DUVAL, Y.; DURAND-GASSELIN, T.; KONAN, K.; C. In vitro vegetative propagation of oil palm (Elaeis guineensis Jacq.). Oleagineux, v.43, p.145-47, 1988.

EHRENDORFER, F. Adaptive significance of major taxonomic characters and morphological trends in angiosperms. In: HEYWOOD, V.H. (Ed.). Taxonomy and ecology. London: Academic Press, p.317-327, 1973.

ELKONIN, L. A.; PAKHOMOVA, N. V. Influence of nitrogen and phosphorus on induction embryogenic callus of sorghum. Plant Cell, and Tissue Organ Culture, p.115-123, 2000. 
ELMEER, K. E. S. Factors regulating somatic embryogenesis in plants. In: ASLAM, J.; SRIVASTAVA, P. S.; SHARMA, M. P. (Eds.) Somatic embryogenesis and gene expression. New Delhi: Narosa Publishing House, p.56-81, 2013.

FEHÉR, A.; PASTERNARK, T.; OTVOS, K.; MISKKOLCZI, P.; DUDITS, D. Induction of embryogenic competence in somatic plant cells: a review. Section Botany, v.57, p.512, 2002.

FERNÁNDEZ-GUIJARRO, B., CELESTINO, C., TORIBIO, M. Influence of external factors on secondary embryogenesis and germination in somatic embryos from leaves of Quercus suber. Plant Cell, Tissue and Organ Culture, v. 41, p.99-106, 1995.

FERREIRA, C. B. B.; LOPES, M. T. G., LOPES, R.; CUNHA, R. N. V.; MOREIRA, D. A.; ARROS,W. S.; MATIELLO, R. R. Molecular genetic diversity of oil palm progenies. Pesquisa Agropecuária Brasileira, v.47, p.378-384, 2012.

FOCKS, N.; BENNING, C. Wrinkled1: a novel, low-seed-oil mutant of Arabidopsis with a deficiency in the seed-specific regulation of carbohydrate metabolism. Plant Physiology, p.91-101, 1998.

GAJ, M. D.; Factors influencing somatic embryogenesis induction and plant regeneration with particular reference to Arabidopsis thaliana (L.) Heynh. Plant Growth Regulation, Dordrecht, v.43, p.27-47, 2004.

GANTAIT, S.; SINNIAH, U. R.; SURANTHRAN, P.; PALANYANDY, S. R.; SUBRAMANIAM, S. Improved cryopreservation of oil palm (Elaeis guineensis Jacq.) polyembryoids using droplet vitrification approach and assessment of genetic fidelity. Protoplasma, v.252, p.89-101, 2015.

GAUTHERET, R. J.; Culture Du tissu cambial. Comptes Rendus dês Seances de la Societe de Biologie, v.198, p.2195-2196, 1934.

GAUTHERET, R. J.; Plant Tissue Culture: A history. Bot. Mag. Tokyo, p.393-410, 1983.

GOMES, H. T.; BARTOS, P. M. C.; SILVA, C. O.; AMARAL, L. I. V.; SCHERWINSKIPEREIRA, J.E. Comparative biochemical profiling during the stages of acquisition and development of somatic embryogenesis in African oil palm (Elaeis guineensis Jacq.). Plant Growth Regulation, v.74, p.199-208, 2014.

GOMES, H. T.; BARTOS, P. M. C.; SCHERWINSKI-PEREIRA, J. E. Optimizing rooting and survival of oil palm (Elaeis guineensis) plantlets derived from somatic embryos. In Vitro Cellular and Developmental Biology - Plant, v.51, p.111-117, 2015.

GOMES, H. T.; BARTOS, P. M. C.; BALZON, T. A.; SCHERWINSKI-PEREIRA, J. E. Regeneration of somatic embryos of oil palm (Elaeis guineensis) using temporary immersion bioreactors. Industrial Crops and Products, v.89, p.244-249, 2016.

GÓMEZ-CADENAS, A.; MEHOUACHI, J.; TADEO, F. R.; PRIMO-MILLO, E.; TALON, $M$. Hormonal regulation of fruitlet abscission induced by carbohydrate shortage in citrus. Planta, v.210, p.636-643, 2000. 
GONTIJO, T. S.; FERNANDES, E. A.; SARAIVA, M. B. Análise da volatilidade do retorno da commodity dendê: 1980-2008. Revista de Economia e Sociologia Rural, v.49, p.857-874, 2011.

GORRET, N.; ROSLI, S. K. B.; OPPENHEIM, S. F.; WILLIS, L. B.; LESSARD, P. A.; RHA, C.; SINSKEY, A. J. Bioreactor culture of oil palm (Elaeis guineensis) and effects of nitrogen source, inoculums size, and conditioned medium on biomass production. Journal of Biotechnology, v.108, p.253-263, 2004.

GROUT, B. W. W.; ASTON, M. J. Transplantin of cauliflower plants Regenerated from meristem culture. I. Water loss and water transfer related to Changes in leaf wax and to xylem regeneration. Horticultural Research, v.17, p.1-7, 1977.

GUERRA, M. P.; HANDRO, W. Somatic embryogenesis and plant regeneration in embryo cultures of Euterpe edulis Mart. (Palmae). Plant Cell Report, v.7, p.550-552, 1998.

GUERRA, M. P.; TORRES, A. C.; TEIXEIRA, J. B. Embriogênese somática e sementes sintéticas. In: TORRES, A. C.; CALDAS, L. S.; BUSO, J. A. (ads.). Culturas de tecidos e Transformação Genética de Plantas. Brasília, Embrapa-CBAB. v.2, p.533-568, 1999.

HAMEED, H. B.; LAI, L. F.; CHIN, L. H. Production of biodiesel from palm oil (Elaeis guineensis) using heterogeneous catalyst: An optimized process. Fuel Processing Technology, v.90, p.606-610, 2009.

HANSEN, S.B.; PADFIELD, R.; SYAYUTI, K.; EVERS, S.; ZAKARIAH, Z.; MASTURA, $S$. Trends in global palm oil sustainability research. Journal of Cleaner Production, v. 100, p.140-149, 2015.

HERINGER, A.S.; STEINMACHER, D.A.; FRAGA, H.P.F.; VIEIRA, L.N.; MONTAGNA, T.; QUINGA, L.A.P.; QUOIRIN, M.G.G.; JIMÉNEZ, V.M.; GUERRA, M.P. Improved high-efficiency protocol for somatic embryogenesis in Peach Palm (Bactris gasipaes Kunth) using RITA® temporary immersion system. Scientia Horticulturae, v.179, p.284-292, 2014.

HICKS, G. S. Adventitious rooting of apple microcuttings in vitro: an anatomical Study. Canadian Journal of Botany, v.65, p.1913-1920, 1987.

HIGASHI, E. N.; SILVEIRA, R. L. V. A.; GONÇALVES, A. N. Propagação vegetativa de Eucalyptus: princípios básicos e a sua evolução no Brasil. Instituto de pesquisas e Estudos Florestais, Circular Técnica, v.192, p.14, 2000.

HILAE, A.; TE-CHATO, S. Effects of carbon sources and strength of MS medium on germination of somatic embryos of oil palm (Elaeis guineensis Jacq.). Songklanarin Journal of Science Technology, v.27, p.629-635, 2005.

HONG, J. Uncertainty propagation in life cycle assessment of biodiesel versus diesel: Global warming and non-renewable energy. Bioresource Technology, v.113, p.3-7., 2012. 
HUONG, L. T. L.; BAIOCCO, M.; HUY, B. P.; MEZZETTI, B.; SANTILLOCCHI, R.; ROSATI, P. Somatic embryogenesis in canary Island date palm. Plant Cell, Tissue and Organ Culture, v.56, p.1-7. 1999.

JAYANTHI, M.; MOHAN, N. M.; MANDAL, P. K. Direct somatic embryogenesis and plantlet regeneration in oil palm. Journal of Plant Biochemistry and Biotechnology, v.20, p.249-251, 2011.

JIMÉNEZ, V. M. Regulation of in vitro somatic embryogenesis with emphasis on the role of endogenous hormones. Revista Brasileira de Fisiologia Vegetal, v.13, p.196-223, 2001.

JIMÉNEZ, V. M. Involvement of plant hormones and plant growth regulators on in vitro somatic embryogenesis. Plant Growth Regulation, v.47, p.91-110, 2005.

JOUANNIC, S.; LARTAUD, M.; HERVÉ, J.; COLLIN, M.; ORIEUX, Y.; VERDEIL, J. L.; TREGEAR, J. W. The shoot apical meristem of oil palm (Elaeis guineensis; Arecaceae): developmental progression and dynamics. Annals of Botany, v.108, p.1477-1487, 2011.

JOURDAN, C.; REY, H. Architecture and development of the oil-palm (Elaeis guineensis Jacq.) root system. Plant and Soil, v.189, p.33-48, 1997.

KANCHANAPOOM, K.; DOMYOAS, P. The origin and development of embryoids in oil palm (Elaeis guineensis Jacq.) embryo culture. Science Asia, v.25, p.195-202, 1999.

KARUN, A.; SIRIL, E. A.; RADHA, E.; PARTHASARATHY, V. A. Somatic embryogenesis and plantlet regeneration from leaf and inflorescence explants of arecanut (Areca catechu L.). Current Science, v.86, p.25, 2004.

KOMAMINE, A.; KAWAHARA, R.; MATSUMOTO, M.; SUMABORE, S.; TOYA, T.; FUJIWARA A.; TSUKAHARA, M.; SMITH, J.; ITO, M.; FUKUDA, H.; NOMURA, K.; FUJIMURA, T. Mechanisms of somatic embryogenesis in cell cultures: physiology, biochemistry, and molecular biology. In Vitro Celular and Development Biology Plant, v.28, p.11-14, 1991.

KOMATSUDA, T.; LEE, W.; OKA, S. Maturation and germination of somatic embryos as affected by sucrose and plant growth regulators in soybeans Glycine gracilis Skvortzland Glycine max (L.) Merr. Plant Cell, Tissue and Organ Culture, v.18, p.103113, 1992.

KONAN, K. E.; DURAND-GASSELIN, T.; KOUADIO, Y. J.; FLORI, A.; RIVAL, A.; DUVAL, Y.; PANNETIER, C. In Vitro conservation of oil palm somatic embryos for 20 years on a hormone-free culture medium: characteristics of the embryogenic cultures, derived plantlets and adult palms. Plant Cell Reports, v.29, p.1-13, 2010.

KRIKORIAN, A. D.; BERQUAM, D. L. Plant cell and tissue culture: the role of Haberlandt. Botanical Review, v.35, p.59-88, 1969. 
KUMAR, S. P.; KUMARI, B. D. R. Factors Affecting on Somatic Embryogenesis of Safflower (Carthamus tinctorius L) at Morphological and Biochemical Levels. World Journal of Agricultural Sciences, v.7, p.197-205, 2011.

KUMAR, K.; RAO, I. U. Morphophysiologicals problems in acclimatization of micropropagated plants in - ex vitro conditions - a reviews. Journal Ornamental and Horticultural Plants, v.2, p.271-283, 2012.

LARCHER, W. Ecofisiologia Vegetal. São Carlos: RiMa Artes e Textos, p.531, 2000.

LEDO, A. S.; LAMEIRA, O. A.; BENBADIS, A. K.; MENEZES, I. C. de; OLIVEIRA, M. do S. P. de; FILHO, S. M. Embriogênese somática em embriões zigóticos de Euterpe oleracea Mart. Revista Brasileira Fruticultura, v.24, p.3, 2002.

LEIFERT, C.; MURPHY, K. P.; LUMSDEN, P. J. Mineral and carbohydrate nutrition of plant cell and tissue culture. Critical Reviews in Plant Sciences. v.14, p.83-109, 1995.

LEIGHTNER, J.; JAMES D. W.; DOONER, H. K.; BROWSE J. Altered body morphology is caused by increased stearate level in a mutant of Arabidopsis. Plant Journal, v.6, p.401-412, 1994.

LEITE, R. C.; LEAL, M. R. O bicombustível no Brasil. Novos Estudos, p.15-21, 2007.

LELJAK-LEVANIC', D.; BAUER, N.; MIHALJEVIC', S.; JELASKA, S. Somatic embryogenesis in pumpkin (Cucurbita pepo L.): control of somatic embryo development by nitrogen compounds. Journal Plant Physiology, p.229-236; 2004.

LIPAVSKÁ, H.; KONRÁDOVÁ, H. Invited review: somatic embryogenesis in conifers: the role of carbohydrate metabolism. In vitro Cellular and Develpmental Biololgy Plant, v.40, p.23-30, 2004.

LUIS, Z. G.; SCHERWINSKI-PEREIRA, J. E. An improved protocol for somatic embryogenesis and plant regeneration in macaw palm (Acrocomia aculeata) from mature zygotic embryos. Plant Cell, Tissue and Organ Culture, v.118, p.485-496, 2014.

LUIS, Z. G.; BEZERRA, K. M. G.; SCHERWINSKI-PEREIRA, J. E. Adaptability and leaf anatomical features in oil palm seedlings produced by embryo rescue and pregerminated seeds. Brazilian Journal of Plant Physiology, v.22, p.209-215, 2010.

MAGALHÃES, J. R.; WILCOX, G. E. Interação entre formas de nitrogênio e reguladores de crescimento. Pesquisa Agropecuária Brasileira, v.6. p.576-585, 1987.

MALAVOLTA, E. Avaliação do estado nutricional das plantas: princípios e aplicações. Piracicaba: Patafós, p.319, 1997.

MARBUN, C. L. M.; TORUAN-MATHIUSA, N.; REFLINIA; UTOMOA, C.; LIWANG, T. Micropropagation of embryogenic callus of oil palm (Elaeis guineensis Jacq.) using temporary immersion system. Procedia Chemistry, v.14, p.122-129, 2015. 
MARTINE, B.M.; LAURENT, K.K.; PIERRE, B.J.; EUGÈNE, K.K.; HILAIRE, K.T.; JUSTIN, K.Y. Effect of storage and heat treatments on the germination of oil palm (Elaeis guineensis Jacq.) seed. African Journal of Agricultural Research, v.4, p.931937, 2009.

MERKLE, S. A.; PARROTT, W. A.; FLINN, B. S. Morphogenic aspects of somatic embryogenesis. In: THORPE, T.A. (Ed.). In vitro embryogenesis in plants. Dordrecht: Kluwer Academics, p.155-203, 1995.

MENÉNDEZ-YUFFÁ, A.; BARRY-ETIENNE, D.; BERTRAND, B.; GEORGET, F.; ETIENNE, $\mathrm{H}$. A comparative analysis of the development and quality of nursery plants derived from somatic embryogenesis and from seedlings for large-scale propagation of coffee (Coffea arabica L.). Plant Cell, Tissue and Organ Culture, v.102, p.297-207, 2010.

MICHAUX-FERRIÈRE N.; CARRON M. P. Histology of early somatic embryogenesis in Hevea brasiliensis: The importance of the timing of subculturing. Plant Cell, Tissue ang Organ Culture, v.19, p.243-256, 1996.

MIQUEL M.; BROWSE J. Lipid biosynthesis in developing seeds. In: Kigel J. Galili (eds). Seed Development and Germination. p.195-214, 1995.

MOGHADDAM, M. R. B.; ENDE, W. V. Sugars and plant innate immunity. Journal of Experimental Botany, v.63, p.3989-3998, 2012.

MONTOYA, C.; COCHARD, B.; FLORI, A.; CROS, D.; LOPES, R.; CUELLAR, T.; ESPEOUT, S.; SYAPUTRA, I.; VILLENEUVE, P.; PINA, M.; RITTER, E.; LEROY, T.; BILLOTTE, N. Genetic Architecture of Palm Oil Fatty Acid Composition in Cultivated Oil Palm (Elaeis guineensis Jacq.) Compared to Its Wild Relative E. oleifera (H.B.K) Cortés. Plos One, v. 9, p. 95412-95412, 2014.

MOORE, J. R. Phospholipid biosynthesis. Annual Rev. of Plant Plysiology, v.33, p.235-259, 1982.

MOZER, T. J. Control of protein synthesis in barley aleurone layers by the plant hormones gibberellic acid and abscisic acid. Cell, v.20, p.479-485, 1980.

MUKHERJEE, I.; SOVACOOL, B.K. Palm oil-based biofuels and sustainability in southeast Asia: A review of Indonesia, Malaysia, and Thailand. Renewable and Sustainable Energy Reviews, v.37, p.1-12, 2014.

MURASHIGE, T.; SKOOG, F. A revised medium for rapid growth and bioassays with tobacco tissue cultures. Physiology Plant, v.15, p.437-497, 1962.

NANTHA, H. S.; TISDELL, C. The orangutan-oil palm conflict: economic constraints and opportunities for conservation. Biodiversity and Conservation, v.18, p.487-502, 2009. 
NORIEGA, C.; SONDAHL, M. R. Arabica coffee micropropagation through somatic embriogenesis via bioreactors. In: COLLOQUE SCIENTIFIQUE INTERNATIONAL SUR LE CAFÉ, Montpelier. Annales. Paris: ASIC, p.73-81, 1993.

OHLROGGE, J. B.; BROWSE J. Lipid Biosynthesis. The Plant Cell, v.7, p.957-970, 1995.

OOSTERVEER, P. Promoting sustainable palm oil: viewed from a global networks and flows perspective. Journal of Cleaner Production, v.12, p.1-8, 2014.

OSBORNE, D. J. Interactions of hormonal substances in the growth and development of plants. Journal of the Science of Food and Agriculture, v.16, p.1-13, 1965.

PANNETIER, C.; ARTHUIS, P.; LIEVOUX, D. Néoformation de jeunes plantes d' Elaeis guineensis à partir de cals primaires obtenus sur fragments foliaires cultivés in vitro. Oléagineux, v.36, p.119-122, 1981.

PANDOLFINI, T.; MOLESINI, B; SPENA, A. Molecular dissection of the role of auxin in fruit initiation. Trends in Plant Science, v. 12, p. 237-238, 2007.

PASSOS, L. P. Métodos analíticos e laboratoriais em fisiologia vegetal. Coronel Pacheco: EMBRAPA, CNPGL, p.223, 1996.

PEREIRA, A. R.; CARVALHO, S. P.; PASQUAL, M.; SANTOS, F. C. Embriogênese somática direta em explantes foliares de Coffea arabica L. Cv. acaiá cerrado: efeito de citocinina e ácido giberélico. Ciência Agrotécnica, v.31, p.332-336, 2007.

PÉREZ-NUÑEZ, M. T.; CHAN, J. L.; SAÉNZ, L.; GONZALEZ, T.; VERDEIL, J. L.; OROPEZA, C. Improved somatic embryogenesis from Cocos nucifera L. plumule explants. In vitro Celular and Developmental Biology -Plant v.42, p.37-43, 2006.

PESCADOR, R.; KERBAUY, G. B.; KRAUS, J. E.; FERREIRA, W. M.; GUERRA, M. P.; FIGUEIREDO-RIBEIRO, R. C. Changes in soluble carbohydrates and starch amounts during somatic and zygotic embryogenesis of Acca sellowiana (Myrtaceae). In Vitro Cellular \& Developmental Biology - Plant, v.44, p.289-299, 2008.

PORTER, J. R.; LAWLOR, D. W. Plant growth: interactions in nutrition and environment. Cambridge: University of Cambridge Press, p.284, 1991.

RABÉCHAULT, H.; MARTIN, J.P. Multiplication végétative du palmier a huile (Elaeis guineensis Jacq.) a l'aide de cultures de tissus folaires. Comptes Rendus Hebdomadaires des Séances de l'Academie des Sciences. v.285, p.1735-1737, 1976.

RAMOS, L. P.; WILHELM, H. M. Current status of biodiesel development in Brazil. Applied Biochemistry and Biotechnology, v.121, p.807-820, 2005.

RAVEN, P. H.; EVERT, R. F.; EICHHORN, S. E. Biologia Vegetal. 5.ed. Rio de Janeito: Editora Guanabara, p.728, 1996. 
REIDIBOYM-TALLEUX, L.; MARCH, G. G. Lipid and fatty composition in nonembryogenic calli and embryogenic tissues in wild cherry (Prunus avium). Physiologia Plantarum, v.105. p.513- 520, 1999.

REINERT, J. Morphogenese und ihre kontrolle an geweberkulturen aus karotten. Naturwissenschsften, v.45, p.344-345, 1958.

REZENDE, J. C.; FERREIRA, E. A.; PASQUAL, M.; VILLA, F.; BOTELHO, C. E.; CARVALHO, S. P. Development of Coffea arabica L. seedlings obtained from direct somatic embryogenesis. Coffea Science, v.3, p.30-37, 2008.

RIBEIRO, L. M.; OLIVEIRA, D. M. T.; GARCIA, Q. S. Structural evaluations of zygotic embryos and seedlings of the macaw palm (Acrocomia aculeata, Arecaceae) during in vitro germination. Trees, v.26, p.851-863, 2012.

RIVAL, A.; ABERLENC, F.; MORCILLO, F.; TREGEAR, J.; VERDEIL, J. L.; DUVAL, Y. Scaling-up in vitro clonal propagation through somatic embryogenesis : the case of oil palm (Elaeis guineensis Jacq.). Plant Tissue Culture and Biotechnology, v.3, p.7482, 1997.

RODRIGUES, L. R.; OLIVEIRA, J. M. S.; MARIATH, J. E. A. Anatomia vegetal aplicada ao estudo de sistemas androgênicos in vitro. Revista Brasileira de Biociências, v.2, p.159-167, 2004.

SAIFUDDIN, M.; GOH, P. E.; HO, W. S.; MONERUZZAMAN, K. M.; FATIMA, A. Biodiesel production from waste cooking palm oil and environmental impact analysis. Bulgarian Journal of Agricultural Science, v.20, p.186-192, 2014.

SAXENA, S.; DHAWAN, V. Regeneration and large-scale propagation of bamboo (Dendrocalamus strictus Nees) through somatic embryogenesis. Plant Cell Reports, v.18, p.438-443, 1999.

SCHERWINSKI-PEREIRA, J. E.; GUEDES, R. S., SILVA, T. L.; FERMINO, J. P.; COSTA, F. S. Somatic embryogenesis and plant regeneration from oil palm thin cell layer. In Vitro Cellular and Development Biology, v.46, p.378-385, 2010.

SCHWENDIMAN, J.; PANNETIER, C.; N. MICHAUX-FERRIERE Histology of Somatic Embryogenesis from Leaf Explants of the Oil Palm Elaeis guineensis. Annals of Botany, v.62, p.43-52, 1988.

SEN, J.; KALIA, S.; GUHA-MUKHERJEE, S. Level of endogenous free amino acids during various stages of culture of Vigna mungo (L.) Hepper-somatics embryogenesis, organogenesis and plant regeneration. Current Science, v.82, p.429-433, 2002.

SGHAIER-HAMMAMI, B.; DRIRA, N.; JORRIN-NOVO, J. V. Comparative 2-DE proteomic analysis of date palm (Phoenix dactylifera L.) somatic and zigotic embryos. Journal of Proteomics, v.73, p.161-177, 2009.

SHARP, W. R.; SONDAHL, M.; CALDAS, L. S.; MARAFFA, S. B. The physiology on in vitro asexual embryogenesis. Horticultural Review, v.2, p. 268-310, 1980. 
SILVA, R. C.; LUIS, Z. G.; SCHERWINSKI-PEREIRA, J. E. Differential responses to somatic embryogenesis of different genotypes of Brazilian oil palm (Elaeis guineensis Jacq.). Plant Cell, Tissue and Organ Culture, DOI 10.1007/s11240-012-0170-5, 2012.

SILVA, R. C.; LUIS, Z. G.; SCHERWINSKI-PEREIRA, J. E. The histodifferentiation events involved during the acquisition and development of somatic embryogenesis in oil palm (Elaeis guineensis Jacq.). Plant Growth Regulation, v.72, p.67-80, 2013.

SOH, A. C.; WONG, G.; TAN, C. C.; CHEW, P. S.; CHONG, S. P.; HO, Y. W.; WONG, C. K.; CHOO, C. N.; NOR-AZURA, H.; KUMAR, K. Commercial-scale propagation and planting of elite oil palm clones: research and development towards realization. Journal of Oil Palm Research, v.23, p.935-952, 2011.

SOUZA, F. V. D.; JUNGHANS, T. G.; SOUZA, A. S.; SANTOS-SEREJO, J. A.; COSTA, M. A. P. C. Micropropagação. In: SOUZA, A.S., JUNGHANS, T.G (Eds.). Introdução a micropropagação de plantas. Bahia, Embrapa, p.38-52, 2006.

STARITSKY, G. Tissue culture of the oil palm (Elaeis guineensis Jacq.) as a tool for its vegetative propagation. Euphytica, v.19, p.288-292, 1970.

STEINMACHER, D. A.; KROHN, N. G.; DANTAS, A. C.; STEFENON, V. M.; CLEMENT, C. R.; GUERRA, M. P. Somatic embryogenesis in peach palm using the thin cell layer technique: induction, morpho-histological aspects and AFLP analysis of somaclonal variation. Annals of Botany, p.1-11, 2007.

SUMATHI, S.; CHAI, S. P.; MOHAMED, A. R. Utilization of oil palm as a source of renewable energy in Malaysia. Renewable and Sustainable Energy Reviews, v.12, p.2404-2421, 2008.

SUNDRAM, K.; SAMBANTHAMURTHI, R.; TAN, Y. Palm fruit chemistry and nutrition. Asia Pacific Journal of Clinical Nutrition, v.12, p.355-362, 2003.

SURRE, C.; ZILLER, R. La palmera de aceite. Editorial Blume. Coleccion Agricultura Tropical. 1969.

SUTTER, E. G.; LUZA, J. Developmental anatomy of roots induced by Agrobacterium rhyzogenes in Malus pumila ' $M-26$ ' shoots grown in vitro. International Journal of Plant Botany, v.154, p.59-67, 1993.

SUTTER, E. Stomatal and cuticular water loss from apple, cherry, and sweet gum plants after removal in vitro culture. Journal of the American Society Horticulture Science, v.113, p.234-238, 1988.

TAIZ, L. Z.; ZEIGER, E. Fisiologia vegetal. Porto Alegre: ARTMED, 4ํeㄹição, p.719, 2009.

TARMIZI, A. H.; NORJIHAN, M. A.; ZAITON, R. Multiplication of oil palm suspension cultures in a bench-top (2 litre) bioreactor. Journal of Oil Palm Research, v.16, p.4449, 2004. 
TARMIZI, A. H.; SAMSAUL, K. R.; ZAITON, R.; ROSLI, M. Y. Multiplication of oil palm liquid cultures in bioreactors. Journal of Oil Palm Research Special Issue on Malaysia-MIT Biotechnology Partnership Programme, v.1, p.44-50, 2008.

TE-CHATO, S.; HILAE, A.; YEEDUM, I. Improve callus induction and embryogenic callus formation from cultured young leaves of oil palm seedling. Thai Journal of Agricultural Science, v.35, p.407-413, 2002.

TEISSON, C.; ALVARAD, D.; BERTHOULY, M. Culture in vitro par immersion temporaire: un nouveau recipient. Plantations Recherche, v.2, p.29-3, 1995.

TEIXEIRA, J. B.; SONDAHLL, M. R.; KIRBY, E. G. Somatic embryogenesis from immature zygotic embryos of oil palm. Plant Cell, Tissue and Organ Culture, v.34, p.227-233, 1993.

TEIXEIRA, J. B.; SONDAHLL, M. R. e KIRBY, E. G. Somatic embryogenesis from immature inflorescences of oil palm. Plant Cell Reports, v.13, p.247-250. 1994.

TEIXEIRA, J. B.; SONDAHL, M. R.; NAKAMURA, T.; KIRBY, E. G., Establishment of oil palm cell suspensions and plant regeneration. Plant Cell, Tissue and Organ Culture, v.40, p.105-111. 1995.

THOMAS, R.; BOURA, A. Palm stem anatomy: phylogenetic or climatic signal? Botanical Journal of the Linnean Society, v.178, p.467-488, 2015.

THORPE, T. A. History of plant tissue culture. Molecular Biotechnology, v.37, p.169180, 2007.

THUZAR, M.; VANAVICHIT, A.; TRAGOONRUNG, S.; JANTASURIYARAT, C. Efficient and rapid plant regeneration of oil palm zygotic embryos cv. 'Tenera' through somatic embryogenesis. Acta Physiologiae Plantarum, v.33, p.123-128, 2011.

TITON, M.; XAVIER, A.; OTONI, W. C.; MOTOIKE, S. Y. Efeito dos reguladores de crescimento dicamba e picloram na embriogênese somática em Eucalyptus grandis Revista Árvore, v. 31, p.417-426. 2007.

TORRES, A. C.; CALDAS, L. S.; BUSO, J. A. (Ed.). Cultura de tecidos e transformação genética de plantas. Brasília: Embrapa-SPI/Embrapa-CNPH, v.2. p.87-132, 1998.

TOUCHET, B. D.; DUVAL, Y.; PANNETIER, C. Plant regeneration from embryogenic suspension culture of oil palm (Elaeis guineensis Jacq). Plant Cell Reports. v.10, p.529-532, 1991.

TREGEAR, J. W.; RIVAL, A.; PINTAUD, J. C. A family portrait: unravelling the complexities of palms. Annals of Botany, v.108, p.1387-1389, 2011.

TREWAVAS, A. J. Plant growth substances - metabolic flywheels for plant development. Cell Biology International Reports, v.7 p.569-575, 1983. 
UPENSKI, E. E.; UPENSKAIA, W. J. Reinkultur and ungeschlechtliche fortpflanzung des Volvox minor and Volvox globator in einer synthetischen Nahrlosung. Zeitschrift fuer Botanik, v. 17, p. 273-308, 1925.

UTINO, S.; CARNEIRO, I. F.; CHAVES, L. J. Crescimento e oxidação de explantes de bananeira prata (Musa AAB) in vitro: IV. Concentrações de sais, ácidos ascórbicos e freqüência de subcultivos. Revista Brasileira de Fruticultura, Cruz das Almas, v.23, p.409-412, 2001.

WAHID, M. B.; ABDULLAH, S. N. A.; HENSON, I. E. Oil Palm - Achievements and Potential. Plant Production Science, v.8, p.288-297, 2005.

WAREING, P. F.; PHILLIPS, I. D. J. Growth and differentiation in plants. Oxford: Pergamon, p.343, 1982.

WHITE, P. R. Accessory salts in the nutrition of excised tomato roots. Plant Physiology, v.13, p.391-398, 1938.

WHITE, P. R. Concentrations of inorganic ions as related to growth of excised root-tips of wheat seedlings. Plant Physiology, v.8, p.489-508, 1933.

WHITE, P. R. Influence of some environmental conditions on the growth of excised root tips of wheat seedlings in liquid media. Plant Physiology, v.7, p.613-628, 1932.

WHITE, P. R. Potentially unlimited growth of excised tomato root tips in a liquid medium. Plant Physiology, v.9, p.585-600, 1934.

WILLIAMS, E. S.; MAHESWARAN, B. Somatic Embryogenesis: factors influencing coordinated behavior of cells as an embryogenic group. Annals of Botany, v.57, p.443462, 1986.

WISE, J. M.; TUNNACLIFFE, A. POPP the quest: what do LEA proteins do ? Trends Plant Science, v.9, p.13-17, 2004.

WOODWARD, A. D.; BARTEL, B. Auxin: regulation, action and interaction. Annals of Botanic, v. 95, p. 707-735, 2005.

YENGAR, V. Nuclear and isotopic techniques for addressing nutritional problems, with special reference to current applications in developing countries. Food and Nutrition Bulletin, v.23, p.1-18, 2002.

YOU, X. L.; TAN, X.; DAI, J. L.; LI, J. H.; CHOI, Y. E. Large-scale somatic embryogenesis and regeneration of Panax notoginseng. Plant Cell, Tissue and Organ Culture, v.108, p.333-338, 2012. 


\section{CAPÍTULO 1}

OTIMIZAÇÃO DAS ETAPAS DE INDUÇÃO E MULTIPLICAÇÃO DE CALOS DA EMBRIOGÊNESE SOMÁTICA DE FOLHAS IMATURAS DE DENDEZEIRO (Elaeis guineensis Jacq.) 


\section{RESUMO}

O objetivo do trabalho foi avaliar as respostas morfogênicas in vitro de folhas imaturas de diferentes genótipos de Elaeis guineensis Jacq., bem como verificar as combinações de reguladores de crescimento e condições de cultivo para a melhor indução e multiplicação das linhagens embriogênicas. Inicialmente, segmentos de folhas imaturas de plantas adultas de dendezeiro da variedade B35-17-29 foram inoculadas em meio de cultura de MS suplementado com 0,5 g. $\mathrm{L}^{-1}$ de caseína hidrolisada, 0,5 g. $\mathrm{L}^{-1}$ de glutamina, 2,5 g. $\mathrm{L}^{-1}$ de carvão ativado, $30 \mathrm{~g} \cdot \mathrm{L}^{-1}$ de sacarose, 2,5 g. $\mathrm{L}^{-1}$ de Phytagel contendo cinco concentrações $(0,225,450,675$ e $900 \mu \mathrm{M})$ de ANA, 2,4-D e Picloram. Em seguida, a viabilidade e a eficiência de duas regiões do palmito (apical e basal) foram avaliadas na indução de calos, em seis variedades (B35-29-32, B35-29-33, B35-17-33, B35-17-29, A25-15-11 e A25-14-28), utilizando o melhor tratamento do experimento anterior. Posteriormente, duas consistências de meio nutritivo (líquido e sólido) e dois tipos de calos (primário e embriogênico) da variedade B35-17-29 foram testados para a multiplicação em meio MS suplementado de 0,5 g. $\mathrm{L}^{-1}$ de caseína hidrolisada, 0,5 g. $\mathrm{L}^{-1}$ de glutamina, 0,1 g. $\mathrm{L}^{-1}$ de cisteína, $30 \mathrm{~g} . \mathrm{L}^{-1}$ de sacarose, 2,5 g. $\mathrm{L}^{-1}$ de Phytagel (apenas no meio sólido) e $10 \mu \mathrm{M}$ de 2,4-D. Na indução de calos da variedade B35-17-29, verificou-se que as melhores taxas foram obtidas com a utilização de 2,4-D e Picloram, com médias variando entre 9,5\% (900 $\mu \mathrm{M}$ de 2,4D) e $19 \%$ (225 $\mu \mathrm{M}$ de Picloram). A formação de calo primário nas regiões foliares e nos genótipos analisados foi melhor na parte apical das folhas imaturas (região mais afastada do meristema apical), com médias de indução de até $34,1 \%$. Na etapa de multiplicação, verificou-se que o maior ganho de biomassa fresca (989\%) foi observado com a multiplicação de calos embriogênicos em meio líquido em agitação. Conclui-se que a indução de calos em dendezeiro é genótipo dependente e, de maneira geral, a utilização da auxina Picloram e da parte apical do palmito apresentam as melhores taxas de formação de calos primários. Na etapa de multiplicação, calos embriogênicos apresentam maior acúmulo de biomassa fresca quando o meio líquido sob agitação é utilizado.

Palavras-chave: Arecaceae; propagação clonal; auxinas; meio líquido; genótipos; folhas jovens. 


\section{ABSTRACT}

The main goal of the project was evaluating the morphogenic responses in vitro from half-grown leaves of different Elaeis guineensis Jacq. genotypes, as well as verifying growth retardant combinations and growing conditions for better induction and multiplication of the embryogenic lineage spread. Originally, adult plant's half-grown leaves segments of the African oil palm tree from the variety B35-17-29 were inoculated in MS cultivation environment supplemented with $0,5 \mathrm{~g} \cdot \mathrm{L}^{-1}$ of hydrolised casein, 0,5 g. L ${ }^{1}$ of glutamine, 2,5 g.L ${ }^{-1}$ of activated carbon, $30 \mathrm{~g} \cdot \mathrm{L}^{-1}$ of sucrose, $2,5 \mathrm{~g} \cdot \mathrm{L}^{-1}$ of Phytagel containing 5 concentrations $(0,225,450,675$ e $900 \mu \mathrm{M})$ of NAA, 2,4-D and Picloram. Subsequently, the feasibility and efficiency of two heart of palm's regions (apical and basal) were evaluated on calluses induction, in six varieties (B35-29-32, B35-29-33, B35-17-33, B35-17-29, A25-15-11 e A25-14-28), using the best treatment from the previous experiment. Afterwards, two consistencies of nutrient medium (liquid and solid) and two sorts of calluses (primary and embryogenic) of the variety B35-17-29 were tested for the multiplication in MS media supplemented by $0,5 \mathrm{~g} \cdot \mathrm{L}^{-1}$ of hydrolyzed casein, 0,5 g.L. $\mathrm{L}^{-1}$ of glutamine, $0,1 \mathrm{~g} \cdot \mathrm{L}^{-1}$ de cysteine, $30 \mathrm{~g} \cdot \mathrm{L}^{-1}$ of sucrose, $2,5 \mathrm{~g} \cdot \mathrm{L}^{-1}$ of Phytagel (only on solid media) and $10 \mu \mathrm{M}$ of 2,4-D. On the calluses induction the variety B35-17-29, it was observed that the best rates were obtained using 2,4-D and Picloram, with averages varying between $9,5 \%$ (900 $\mu \mathrm{M}$ of $2,4-\mathrm{D})$ and $19 \%$ (225 $\mu \mathrm{M}$ of Picloram). The primary callus formation on the foliar regions and genotypes analyzed was better on the half-grown leaves apical portion (apical meristem furthest region), with induction averages up to $34,1 \%$. On the multiplication step, it was verified that the best fresh biomass gain (989\%) was seen with embryogenic calluses multiplication in stirring liquid media. It is concluded that the calluses induction on African oil palm tree is dependent genotype and, in general, the use of the Picloram auxin and heart of palm's apical portion present the best primary calluses formation rates. On the multiplication step, embryogenic calluses presented higher fresh biomass accumulation when using stirring liquid-media.

Keywords: Arecaceae; clonal propagation; auxins; liquid-media; genotypes; early leaves. 


\section{INTRODUÇÃO}

A demanda mundial por combustíveis renováveis tem se expandido de forma acelerada nos últimos anos (Hansen et al., 2015). Diante desse cenário, o Brasil tem explorado a sua capacidade para produzir combustíveis alternativos a partir de diversas espécies oleaginosas (Duval et al., 1988; Durand-Gasselin et al., 1990; Rival et al., 1997a; Khaw \& Ng, 1998; Scherwinski-Pereira et al., 2010; Balzon et al., 2013). Dentre as espécies com potencial oleaginoso, o dendezeiro (Elaeis guineensis) mostra-se como uma das plantas mais promissoras, podendo atingir até 7 toneladas de óleo por hectare por ano (Hansen et al., 2015). Contudo, diante das exigências edafoclimáticas, seu cultivo no território brasileiro prevalece em áreas restritas nas regiões norte e nordeste do país (Teixeira, 2005).

Apesar do elevado potencial produtivo da espécie, o dendezeiro é propagado convencionalmente por sementes, que promovem formação de plantios desuniformes, com consequências negativas para a produção e dificuldades nas práticas de manejo (Viegas e Muller, 2000; Konan et al., 2010). Além disso, a propagação por sementes apresenta como incovêniente a baixa taxa de germinação proveniente da dormência que as sementes dessa espécie apresentam (Martine et al., 2009; Myint et al., 2010; Chanprasert et al., 2012).

A cultura de tecidos vegetais via embriogênese somática, é uma das únicas alternativas para propagar vegetativamente o dendezeiro (Jouannic et al., 2011; Soh et al., 2011; Scherwinski-Pereira et al., 2012). Do ponto de vista do potencial de multiplicação e custos envolvidos, a embriogênese somática apresenta vantagens sobre outros sistemas de micropropagação, pois grandes quantidades de embriões podem ser formados, especialmente em suspensões celulares (Staritsky, 1970; Pannetier et al., 1981; Styer, 1985; Zimmerman, 1993). Para a multiplicação vegetativa do dendezeiro, a embriogênese somática tem sido o principal método utilizado (Rabéchault \& Martin, 1976; Corley et al., 1977; Pannetier et al., 1981; Teixeira et al., 1995; Duval et al., 1995; Rival et al., 1997; Konan et al., 2006; Choi et al., 2008; Ooi et al., 2013; Palanyandy et al., 2013; Jayanthi et al., 2015).

No entanto, grande parte dos protocolos vem sendo realizados a partir da utilização de embriões zigóticos como explante inicial (Teixeira et al., 1993; Rajesh et al., 2003; Balzon et al., 2013; Thuzar et al., 2011; Scherwinski-Pereira et al., 2010; Gomes et al., 2016). Contudo, embora a utilização desse explante incial apresente 
diversas vantagens e aplicações, não permite a clonagem de indivíduos já fenotipados em campo. Sendo assim, metodologias que utilizam tecidos somáticos de plantas adultas devem ser desenvolvidas e otimizadas (Te-Chato et al., 2002; Constantin et al., 2015).

Além da influência exercida pelo tipo de explante utilizado, outro fator tem papel fundamental na resposta embriogênica de uma cultura (Inpuay \& Te-chato, 2012). Segundo Leljak-Levanic et al. (2015), indivíduos de uma mesma espécie podem apresentar respostas significativamente diferentes mesmo quando cultivados em condições iguais. De acordo com estes autores, existem diferentes potenciais de adsorção e metabolização dos compostos do meio nutritivo em diferentes genótipos, apresentando assim, respostas distintas ao cultivo in vitro. Para Jiménez (2005), as diferenças genotípicas observadas também estão associadas às variações no conteúdo de hormônios endógenos presentes nos diferentes genótipos, promovendo, assim, respostas morfogênicas distintas. Nesse contexto, torna-se necessário o aperfeiçoamento de protocolos para genótipos que apresentam alto potencial produtivo para a cultura do dendezeiro e para os programas de melhoramento genético da espécie.

Diante disso, o objetivo deste trabalho foi avaliar as respostas morfogênicas in vitro de folhas imaturas de diferentes genótipos de dendezeiros, bem como definir as combinações de reguladores de crescimento e condições de cultivo para a melhor indução e multiplicação das linhagens embriogênicas. 


\section{MATERIAL E MÉTODOS}

\subsection{Local de realização do experimento}

O experimento foi conduzido no Laboratório de Cultura de Tecidos Vegetais (LCT-II) da Embrapa Recursos Genéticos e Biotecnologia, situado em Brasília - DF, Brasil.

\subsection{Obtenção do material vegetal}

Como explante inicial foram utilizadas folhas imaturas de plantas adultas de dendezeiro, dos genótipos: B35-29-32, B35-29-33, B35-17-33, B35-17-29, A25-15-11 e A25-14-28. Os materiais foram gentilmente cedidos pelo Programa de Melhoramento Genético de Dendezeiro da Embrapa Amazônia Ocidental, a partir do Campo Experimental do Rio Urubu, localizado no Rio Preto da Eva - AM, Brasil.

\subsection{Preparo de explantes e indução de calos primários e embriogênicos}

Após coletado em campo (Figura 1 A-C), o material vegetal foi conduzido ao laboratório da Embrapa Recursos Genéticos e Biotecnologia, onde as folhas mais externas foram removidas e o tamanho do palmito reduzido para aproximadamente 30 $\mathrm{cm}$ de comprimento, da região basal meristemática até o ápice foliar do cilindro central (Figura 1 D-F). Em seguida, folhas imaturas, ainda aclorofiladas, obtidas do cilindro central dos palmitos foram desinfestadas por meio de uma lavagem em solução de água e detergente comercial, seguida pela imersão em álcool $70 \%$ por 3 minutos e imersão em hipoclorito de sódio $(\mathrm{NaOCl})$ a $2,5 \%$ de cloro ativo por 20 minutos. Posteriormente, três lavagens foram realizadas em água destilada, deionizada e autoclavada para remoção do excesso das soluções desinfestantes. 

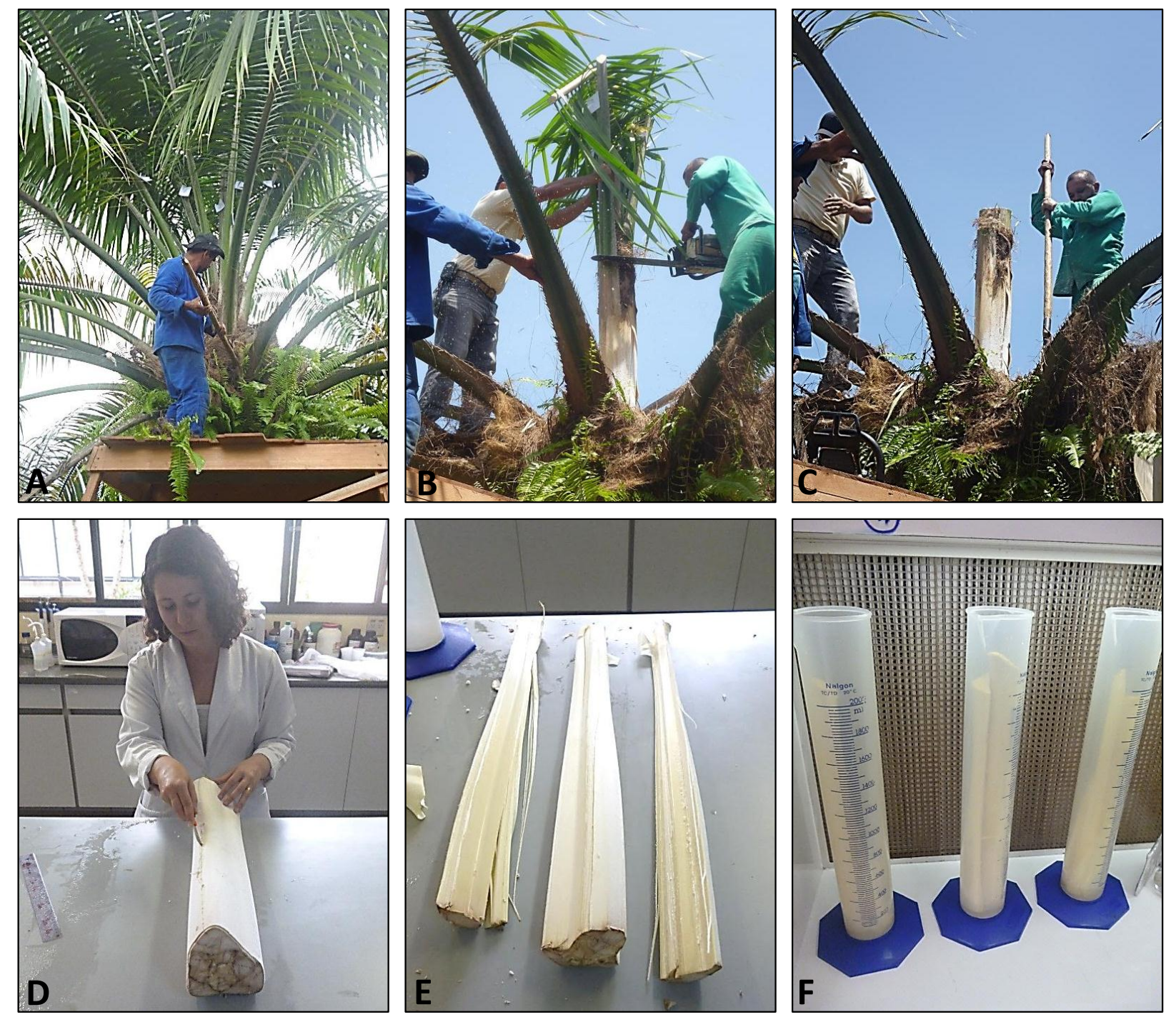

Figura 1. Fases da coleta $(A-C)$ e preparo $(D-F)$ para a desinfestação do palmito de dendezeiro (Elaeis guineensis Jacq.). A. Retirada das folhas adultas. B. Corte do estipe com motosserra. C. Separação do palmito cerca de $20 \mathrm{~cm}$ acima do meristema apical da planta. D e E. Isolamento das folhas imaturas. F. Folhas imaturas em processo de desinfestação.

\subsection{Indução de calos}

Para a indução das linhagens embriogênicas a partir de folhas imaturas de dendezeiro, dois experimentos foram realizados, como segue descrito abaixo.

\subsubsection{Efeito dos diferentes tipos e concentrações de auxinas}


Inicialmente foi avaliada a influência de cinco concentrações (0, 225, 450, 675 e $900 \mu \mathrm{M}$ ) de ANA (ácido naftalenoacético), 2,4-D (ácido diclorofenoxiacético) e Picloram (ácido aminotricloropicolínico), testados isoladamente, na variedade B35-17-29.

A indução de calos foi realizada a partir da inoculação de segmentos foliares em placas de Petri $(15 \times 90 \mathrm{~mm}$ ), contendo $25 \mathrm{~mL}$ de meio de cultura. O meio básico foi composto pelos sais e vitaminas de MS (Murashige \& Skoog, 1962), suplementado com 0,5 g. $\mathrm{L}^{-1}$ de caseína hidrolisada, 0,5 g. $\mathrm{L}^{-1}$ de glutamina, 2,5 g. $\mathrm{L}^{-1}$ de carvão ativado, $30 \mathrm{~g} . \mathrm{L}^{-1}$ de sacarose, $2,5 \mathrm{~g} . \mathrm{L}^{-1}$ de Phytagel. $\mathrm{O} \mathrm{pH}$ dos meios foi ajustado para $5,7 \pm 0,1$, autoclavados à temperatura de $121^{\circ} \mathrm{C}$ e pressão de $1,3 \mathrm{~atm}$ por 20 minutos.

Foram inoculados seis segmentos de folhas jovens de aproximadamente $1 \mathrm{~cm}^{2}$, provenientes das regiões apical e basal dos palmitos, com a face adaxial em contato com o meio de cultura. Todos os experimentos foram acondicionados no escuro, em sala de crescimento sob temperatura de $25 \pm 2 \stackrel{\circ}{\circ}$.

Nestas condições de cultivo, os explantes foram mantidos por três subcultivos de 60 dias cada para a obtenção de calos primários, e mais um subcultivo de 90 dias para a obtenção de calos embriogênicos. Após os três primeiros subcultivos foram avaliadas a percentagem de formação de calo (Figura 2) e a percentagem de oxidação dos explantes (Figura 3), pelas seguintes notas ( 0 - nenhuma, 1 - pouca, 3 - média e 5 muita formação de calo ou oxidação). Ao final do cultivo, a percentagem de formação de calos embriogênicos também foi avaliada. 

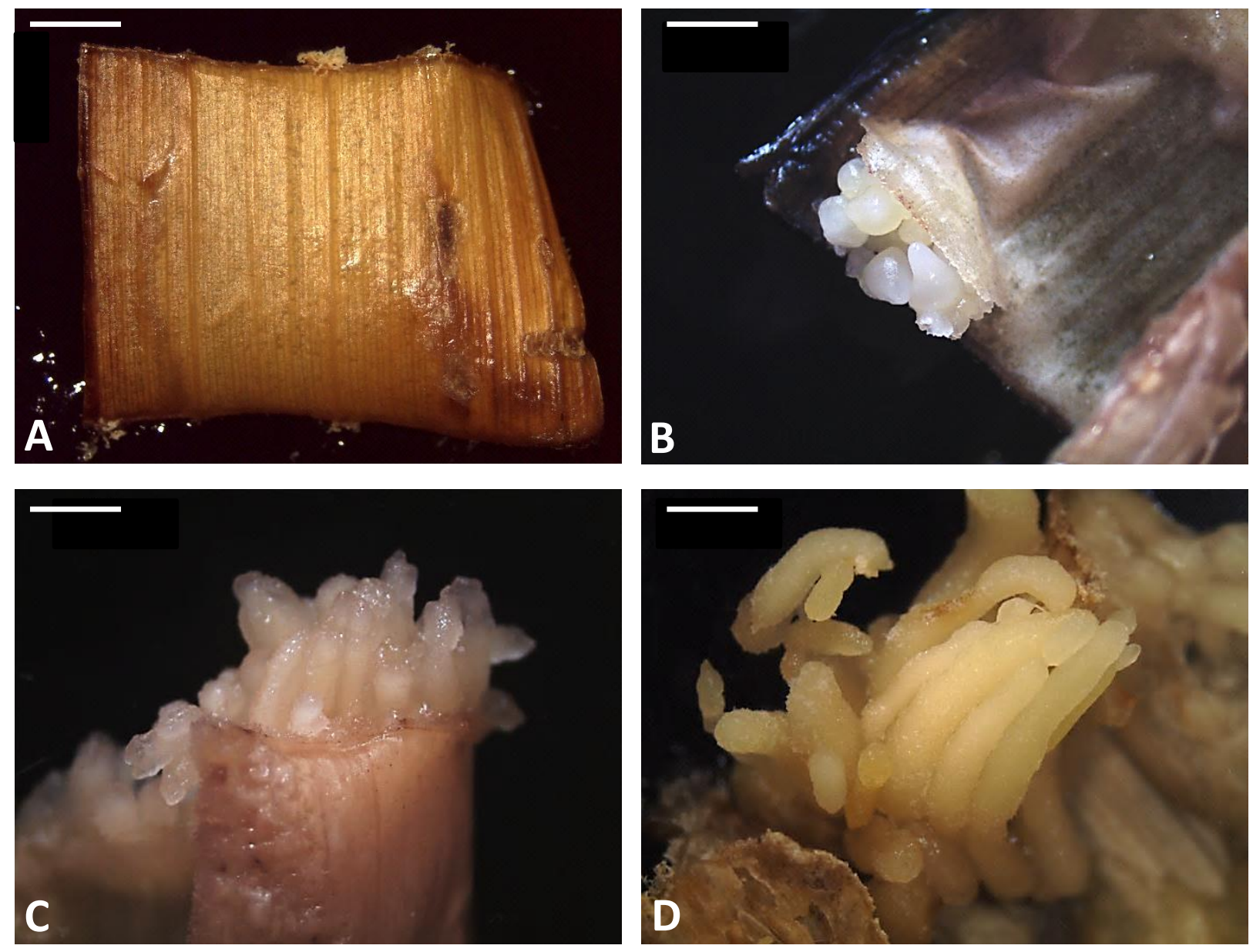

Figura 2. Formação de calos primários induzidos a partir de folhas imaturas de dendezeiro (Elaeis guineensis Jacq.). A. Explante sem formação de calo, ao zero dias de cultivo. B. Calo tipo 1 aos 180 dias de cultivo. C. Calo tipo 3 aos 180 dias de cultivo. D. Calo tipo 5 aos 180 dias de cultivo. Barras: A-D. 2,0 mm. 

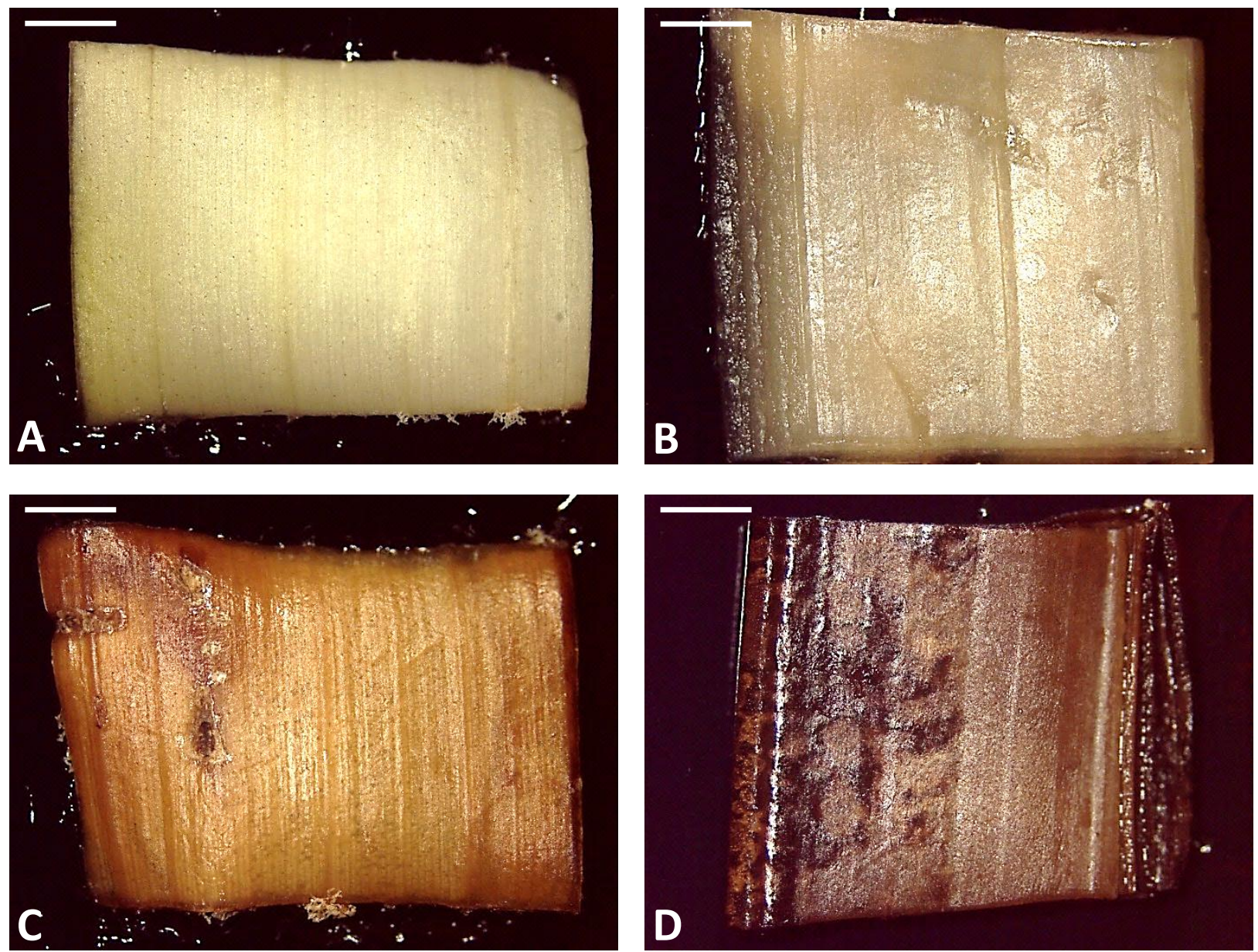

Figura 3. Oxidação de explantes foliares de dendezeiro (Elaeis guineensis Jacq.). A. Explante não oxidado, ao zero dias de cultivo. B. Oxidação tipo 1 aos 180 dias de cultivo. C. Oxidação tipo 3 aos 180 dias de cultivo. D. Oxidação tipo 5 aos 180 dias de cultivo. Barras: A-B. 2,0 mm.

\subsubsection{Efeito do genótipo e da posição da folha}

Neste experimento, a viabilidade e a eficiência de duas regiões do palmito foram avaliadas: apical e basal (Figura 4). Para tanto, realizou-se a indução de calos em seis variedades (B35-29-32, B35-29-33, B35-17-33, B35-17-29, A25-15-11 e A25-14-28), utilizando-se o melhor tratamento do experimento anterior. 


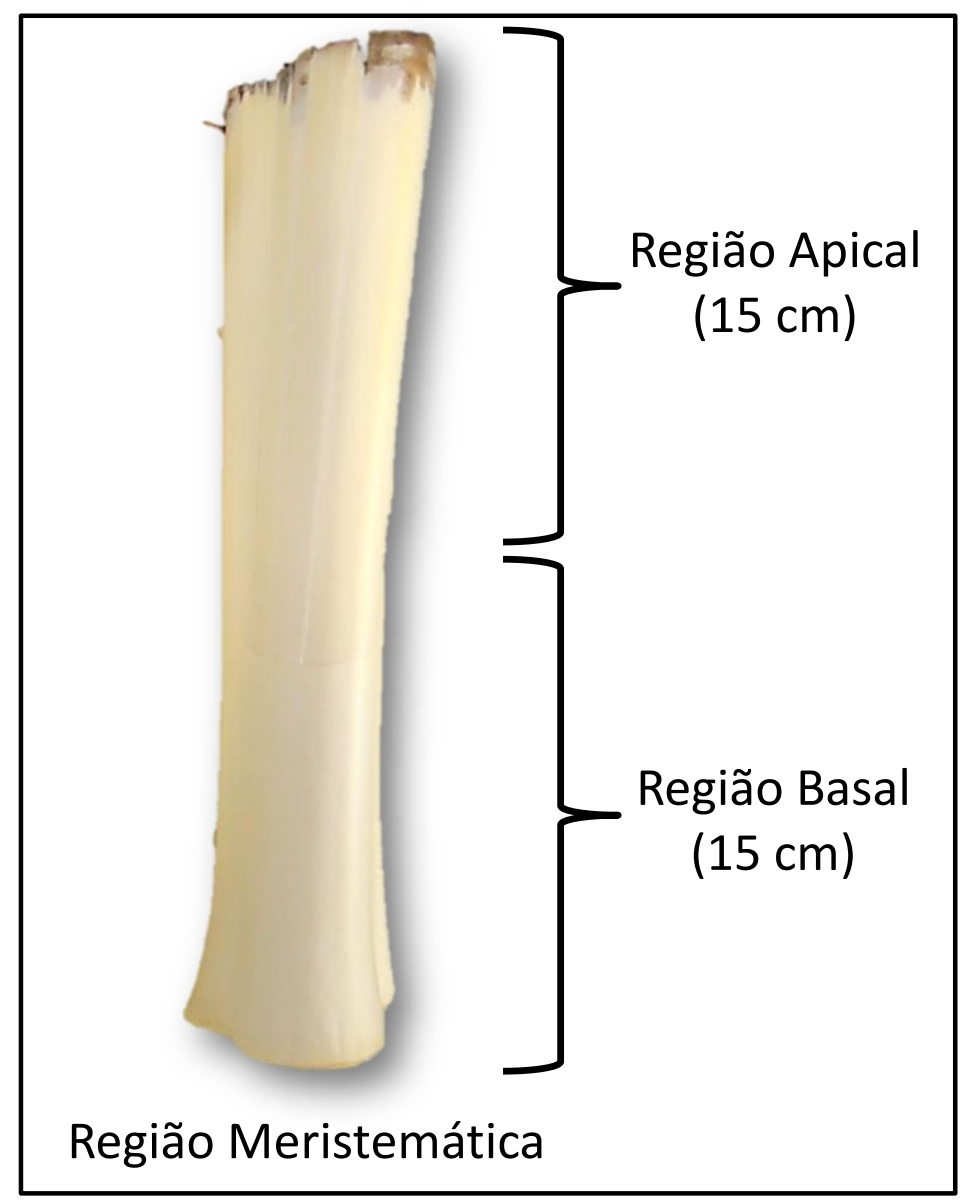

Figura 4. Aspecto do material utilizado como explante inicial para a indução de calos no cultivo in vitro de dendezeiro (Elaeis guineensis Jacq.).

Em ambos os experimentos de indução, o delineamento estatístico empregado foi o inteiramente casualizado, sendo cada tratamento representado por 20 repetições. Cada repetição foi formada por uma placa de Petri $(15 \times 90 \mathrm{~mm})$ contendo seis explantes. Os dados obtidos foram submetidos à análise de variância (ANOVA) com as médias comparadas pelo teste de Scott-Knott a $5 \%$ de probabilidade. Para as análises, utilizou-se o programa de análises estatísticas Sisvar 4.4 (Ferreira 2011). Dados obtidos por contagem foram transformados segundo $(x+1)^{0,5}$.

\subsection{Multiplicação de calos primários e calos embriogênicos}

Neste experimento, duas consistências de meio nutritivo (líquido e sólido) e dois tipos de explantes (calo primário e embriogênico) foram testados. 
Para tanto, aproximadamente $5 \mathrm{~g} \cdot \mathrm{L}^{-1}$ de calos primários e de calos embriogênicos da variedade B35-17-29, provenientes da fase de indução foram cultivados em frascos de Erlenmeyer de $125 \mathrm{~mL}$ de capacidade, contendo $20 \mathrm{~mL}$ de meio nutritivo. $O$ meio foi constituído pela formulação salina e vitaminas de MS (Murashige \& Skoog, 1962), suplementado de 0,5 g.L ${ }^{-1}$ de caseína hidrolisada, 0,5 g.L.-1 de glutamina, 0,1 g.L. ${ }^{-1}$ de cisteína, $30 \mathrm{~g} \cdot \mathrm{L}^{-1}$ de sacarose, 2,5 g. $\mathrm{L}^{-1}$ de Phytagel (apenas no meio sólido) e $10 \mu \mathrm{M}$ de 2,4-D. $\mathrm{O} \mathrm{pH}$ do meio nutritivo foi ajustado para 5,7 $\pm 0,1$ antes da autoclavagem.

Quanto às condições de cultivo, os experimentos foram mantidos em agitadores orbitais a $100 \mathrm{rpm}$ em sala de crescimento com temperatura de $25 \pm 2{ }^{\circ} \mathrm{C}$ e irradiação luminosa de $52 \mu \mathrm{mol} \mathrm{m} \mathrm{m}^{-2} \mathrm{~s}^{-1}$, fornecida por lâmpadas LED (Philips $\AA$ - Green Power 20 W $60 \mathrm{~Hz})$.

Os calos foram cultivados por três subcultivos sucessivos de 30 dias cada. Após 30, 60 e 90 dias de cultivo, o peso fresco das culturas foi quantificado. Aos 90 dias, também foi avaliado o potencial embriogênico das células em suspensão (confirmação da presença de células embriogênicas suspensas no meio nutritivo). Foi realizado o teste histoquímico de azul de Evans $(0,1 \%)$ e carmim acético (2\%), segundo metodologia descrita por Durzan (1988). Para tanto, $1 \mathrm{~mL}$ de meio nutritivo contendo células em suspensão dos tratamentos mantidos em meio líquido (calo primário e embriogênico) do experimento de multiplicação foi colocado em microtubos de $2 \mathrm{ml}$ de capacidade. Após a decantação das células suspensas na amostra, foi retirada a parte líquida dessa solução. Sobre as amostras, foi acrescentado $100 \mu \mathrm{L}$ de azul de Evans $(0,1 \%)$ e após 3 minutos o excesso de corante foi retirado com papel filtro. Em seguida, foram adicionados $100 \mu \mathrm{L}$ de carmim acético (2\%) e, após 3 minutos, o excesso foi retirado. As células foram transferidas para uma lâmina de vidro $(26 \times 76 \mathrm{~mm})$ para a observação em fotomicroscópio com sistema de captura de imagens (Leica ${ }^{\circledR}$ DM750)

O delineamento estatístico empregado foi o inteiramente casualizado, sendo cada tratamento representado por seis repetições. Os dados obtidos foram submetidos à análise de variância (ANOVA), com as médias comparadas pelo teste de Scott-Knott a $5 \%$ de probabilidade. Para as análises utilizou-se o programa de análises estatísticas Sisvar 4.4. Dados obtidos por contagem foram transformados segundo $(x+1)^{0,5}$. 


\subsection{Diferenciação e maturação de embriões somáticos}

A diferenciação dos embriões somáticos foi realizada a partir da inoculação dos calos provenientes da fase de multiplicação, em frascos de vidro de $250 \mathrm{~mL}$ de capacidade, contendo $40 \mathrm{~mL}$ de meio nutritivo de MS, suplementado com 12,3 $\mu \mathrm{M}$ de 2-iP (isopenteniladenina), 0,54 $\mu \mathrm{M}$ de ANA, $0,5 \mathrm{~g} \cdot \mathrm{L}^{-1}$ de glutamina, $0,5 \mathrm{~g} \cdot \mathrm{L}^{-1}$ de caseína hidrolisada, $0,1 \mathrm{~g} \cdot \mathrm{L}^{-1}$ de cisteína, $0,1 \mathrm{~g} \cdot \mathrm{L}^{-1}$ de asparagina, $30 \mathrm{~g} \cdot \mathrm{L}-1$ de sacarose, $2,5 \mathrm{~g} \cdot \mathrm{L}^{-}$ ${ }^{1}$ de Phytagel e pH ajustado para 5,7 $\pm 0,1$. Nessa etapa, os calos foram cultivados por até seis subcultivos de 30 dias cada para a obtenção de embriões somáticos.

\subsection{Regeneração dos embriões somáticos}

A regeneração foi realizada a partir da inoculação de calos contendo embriões somáticos em estádio torpedo, provenientes da fase de diferenciação e maturação. Os explantes foram cultivados em frascos de vidro contendo meio nutritivo de MS (Murashige \& Skoog, 1962) isento de reguladores de crescimento, suplementado com 0,5 g. $\mathrm{L}^{-1}$ de caseína hidrolisada, 0,5 g. $\mathrm{L}^{-1}$ de glutamina, $0,1 \mathrm{~g} \cdot \mathrm{L}^{-1}$ de cisteina, $0,1 \mathrm{~g} \cdot \mathrm{L}^{-1} \mathrm{de}$ asparagina, $30 \mathrm{~g} \cdot \mathrm{L}^{-1}$ de sacarose, 2,5 g...-1 de Phytagel, 2,5 g. $\mathrm{L}^{-1}$ de carvão ativado e $\mathrm{pH}$ ajustado para $5,7 \pm 0,1$. Nesse estágio, os explantes foram cultivados por pelo menos seis subcultivos de 30 dias cada para a obtenção de plantas. Os materiais foram colocados em sala de crescimento com temperatura de $25 \pm 2{ }^{\circ} \mathrm{C}$ e irradiação luminosa de $52 \mu \mathrm{mol} \mathrm{m} \mathrm{m}^{-2} \mathrm{~s}^{-1}$, fornecida por lâmpadas LED (Philips $\AA$ - Green Power 20 W $60 \mathrm{~Hz})$.

\subsection{Otimização do enraizamento in vitro}

Após a etapa de regeneração, as plantas desprovidas de raízes foram enraizadas e alongadas individualmente in vitro, seguindo a metodologia descrita por Gomes et al. (2015). Essas plantas foram cultivadas por até 150 dias em tubos de ensaio $(25 \times 150 \mathrm{~mm}$ ) contendo, nos primeiros 30 dias de cultivo, $10 \mathrm{~mL}$ de meio de MS (Murashige \& Skoog, 1962) sólido, suplementado de 53,7 $\mu \mathrm{M}$ de AlB (ácido indolbutírico), $30 \mathrm{~g} \cdot \mathrm{L}^{-1}$ de sacarose, 2,5 g. $\mathrm{L}^{-1}$ de Phytagel e com pH ajustado para 5,7 \pm 0,1 . Decorridos 30 e 90 dias de cultivo, alíquotas de $3 \mathrm{~mL}$ de meio de consistência líquida foram acrescidas, de mesma constituição dos meios iniciais, constituindo assim, meios de consistência dupla-fase. 


\subsection{Aclimatização das mudas}

Após a etapa de regeneração, as plantas clonadas tiveram suas raízes lavadas em água corrente para eliminação do excesso de meio nutritivo. Em seguida, as mudas foram cultivadas por 45 dias em copos descartáveis brancos de $300 \mathrm{~mL}$ de capacidade contendo uma mistura de Bioplant ${ }^{\circledR}$ e areia na proporção 3:1 (v/v). Os conjuntos foram cobertos, nas três primeiras semanas de cultivo, por copos descartáveis transparentes de $400 \mathrm{~mL}$ de capacidade, furados na parte superior para realização de trocas gasosas. Posteriormente, as plantas foram transplantadas para sacos plásticos pretos com $20 \mathrm{~cm}$ de altura e $20 \mathrm{~cm}$ de diâmetro, preenchidos com terra e adubo vegetal, onde permaneceram por mais 225 dias.

As mudas foram cultivadas em casa de vegetação com cobertura de filme de polietileno transparente de 150 microns, irrigadas manualmente a cada 24 horas, na primeira semana de cultivo, e a cada 48 horas, no restante do processo. 


\section{RESULTADOS E DISCUSSÃO}

\subsection{Indução de calos}

\subsubsection{Efeito dos diferentes tipos e concentrações de auxinas}

A avaliação quanto à formação de calos primários foi realizada aos 180 dias de cultivo, embora tenha sido observada já, aos 30 dias, a mudança de pigmentação e textura dos explantes iniciais utilizados na indução (folha imatura). Inicialmente, os explantes possuíam uma coloração bege clara e foram exibindo uma coloração amarelada, juntamente com a presença de intumescimento em resposta ao contato com o meio de cultivo. Assim como verificado no presente trabalho, Silva et al. (2012) também verificaram em dendezeiro, o intumescimento dos explantes, quando cultivados em meio de indução. Esse intumescimento também é observado em diferentes espécies de palmeiras, como em Acrocomia aculeata (Moura et al., 2009) e Bactris gasipaes Kunth (Steinmacher et al., 2007).

Com relação ao tempo de cultivo, observou-se que a formação de calos iniciou a partir dos 60 dias, apenas no tratamento utilizando 2,4-D. Nesse período, foi possível verificar o rompimento do mesofilo na região em que o explante foi excisado exibindo a formação dos calos primários, que apresentaram coloração bege-amarronzada, formato alongado ou nodular, aspecto compacto e consistência ligeiramente aquosa. No entanto, os melhores resultados de formação de calos primários, levando em consideração os tratamentos mais eficientes, foram obtidos apenas a partir dos 180 dias.

Na Tabela 1, são apresentados os resultados obtidos sobre a formação de calo primário e nível de oxidação dos explantes da variedade B35-17-29 em razão dos diferentes tipos (ANA, 2,4-D e Picloram) e concentrações (0, 225, 450, 675 e $900 \mu \mathrm{M})$ de auxinas. De maneira geral, verificou-se que as melhores taxas de formação de calos primários foram obtidas com a utilização das auxinas 2,4-D e Picloram, com médias variando entre 9,5\% (900 $\mu \mathrm{M}$ de 2,4-D) e 19\% (225 $\mu \mathrm{M}$ de Picloram). Embora o 2,4-D tenha induzido a formação de calo similar ao verificado com o Picloram, foi constatado que, ao final do cultivo, esses calos apresentaram uma consistência mais ressecada, com pouco desenvolvimento quando comparados aos calos formados em meio de cultura com Picloram. Ainda em relação ao desenvolvimento dos calos, foi verificado 
que, de forma geral, a indução com Picloram proporcionou maior percentagem de calos de qualidade tipo 3 e 5 .

Já a auxina ANA não promoveu melhoras significativas na formação de calos primários, independentemente da concentração utilizada, com valores inferiores àqueles observados com a utilização dos demais reguladores. Foi verificada também a formação de raízes nos explantes inoculados com ANA, principalmente nas maiores concentrações utilizadas (675 e $900 \mu \mathrm{M})$, onde a formação de raiz foi de até $25 \%$ dos explantes. 
Tabela 1. Efeito dos diferentes tipos (ANA, 2,4-D e Picloram) e concentrações ( 0,225 , 450, 675 e $900 \mu \mathrm{M}$ ) de auxinas nas médias referentes à formação de calo primário e oxidação de explantes foliares de dendezeiro (Elaeis guineensis Jacq.), variedade B3517-29 aos 180 dias de cultivo

\begin{tabular}{|c|c|c|c|c|c|c|}
\hline \multicolumn{3}{|c|}{ Concentração $(\mu \mathrm{M})$} & \multirow{2}{*}{$\begin{array}{l}\text { Formação de } \\
\text { calo (\%) }\end{array}$} & \multirow{2}{*}{$\begin{array}{l}\text { Calo tipo } 1 \\
(\%)\end{array}$} & \multirow{2}{*}{$\begin{array}{c}\text { Calo tipo } 3 \\
(\%)\end{array}$} & \multirow{2}{*}{$\begin{array}{c}\text { Calo tipo } 5 \\
\text { (\%) }\end{array}$} \\
\hline ANA & 2,4-D & PIC & & & & \\
\hline 0 & 0 & 0 & $0,0 \pm 0,0 b$ & ------- & ------- & ------- \\
\hline 225 & ----- & ----- & $0,0 \pm 0,0 b$ & ------ & ------ & ------- \\
\hline 450 & ----- & ----- & $3,0 \pm 3,0 b$ & $100 \pm 0,0 a$ & $0,0 \pm 0,0 b$ & $0,0 \pm 0,0 a$ \\
\hline 675 & ----- & ----- & $0,0 \pm 0,0 \mathrm{~b}$ & ------- & ------- & ------- \\
\hline 900 & ----- & ----- & $9,5 \pm 1,5 a$ & $100 \pm 0,0 a$ & $0,0 \pm 0,0 b$ & $0,0 \pm 0,0 a$ \\
\hline ----- & 225 & ---- & $3,0 \pm 3,0 b$ & $100 \pm 0,0 a$ & $0,0 \pm 0,0 b$ & $0,0 \pm 0,0 \mathrm{a}$ \\
\hline ----- & 450 & ----- & $18,0 \pm 2,0 a$ & $100+0,0 a$ & $0,0 \pm 0,0 b$ & $0,0 \pm 0,0 a$ \\
\hline ----- & 675 & ----- & $14,0 \pm 2,0 a$ & $100 \pm 0,0 a$ & $0,0 \pm 0,0 b$ & $0,0 \pm 0,0 a$ \\
\hline ----- & 900 & ----- & $9,5 \pm 1,5 \mathrm{a}$ & $100 \pm 0,0 a$ & $0,0 \pm 0,0 b$ & $0,0 \pm 0,0 a$ \\
\hline ----- & ----- & 225 & $19,0 \pm 1,5 a$ & $74,5 \pm 8,5 b$ & $25,5 \pm 8,5 a$ & $0,0 \pm 0,0 a$ \\
\hline ----- & ----- & 450 & $15,0 \pm 2,0 a$ & $57,0 \pm 1,0 b$ & $32,5 \pm 3,5 \mathrm{a}$ & $10,5 \pm 2,5 a$ \\
\hline ----- & ----- & 675 & $15,0 \pm 4,0 a$ & $78,0 \pm 22,1 b$ & $3,0 \pm 3,0 b$ & $19,0 \pm 19,0 a$ \\
\hline ----- & ----- & 900 & $16,5 \pm 2,5 \mathrm{a}$ & $51,5 \pm 23,6 b$ & $37,5 \pm 12,5 a$ & $11,0 \pm 11,0 a$ \\
\hline \multicolumn{3}{|c|}{ Concentração $(\mu \mathrm{M})$} & \multirow{2}{*}{ Oxidação (\%) } & \multirow{2}{*}{$\begin{array}{c}\text { Oxidação tipo } \\
1(\%)\end{array}$} & \multirow{2}{*}{$\begin{array}{c}\text { Oxidação tipo } \\
\mathbf{3}(\%)\end{array}$} & \multirow{2}{*}{$\begin{array}{c}\text { Oxidação tipo } \\
5(\%)\end{array}$} \\
\hline ANA & 2,4-D & PIC & & & & \\
\hline 0 & 0 & 0 & $100,0 \pm 0,0 \mathrm{a}$ & $0,0 \pm 0,0 \mathrm{c}$ & $0,0 \pm 0,0 \mathrm{~b}$ & $100,0 \pm 0,0 a$ \\
\hline 225 & ----- & ----- & $25,0 \pm 25,0 b$ & $0,0 \pm 0,0 c$ & $0,0 \pm 0,0 \mathrm{~b}$ & $100,0 \pm 0,0 a$ \\
\hline 450 & ----- & ----- & $56,0 \pm 0,0 b$ & $25,0 \pm 25,0 \mathrm{c}$ & $75,0 \pm 25,1 \mathrm{a}$ & $0,0 \pm 0,0 b$ \\
\hline 675 & ----- & ----- & $55,5 \pm 5,5 b$ & $0,0 \pm 0,0 c$ & $89,0 \pm 11,0 a$ & $11,0 \pm 11,0 b$ \\
\hline 900 & ----- & ----- & $39,0 \pm 6,0 \mathrm{~b}$ & $0,0 \pm 0,0 \mathrm{c}$ & $100,0 \pm 0,0 a$ & $0,0 \pm 0,0 c$ \\
\hline ----- & 225 & ----- & $47,0 \pm 3,0 \mathrm{~b}$ & $41,5 \pm 8,5 b$ & $58,5 \pm 8,5 a$ & $0,0 \pm 0,0 b$ \\
\hline ----- & 450 & ----- & $27,5 \pm 5,5 b$ & $75,0 \pm 25,1 \mathrm{a}$ & $0,0 \pm 0,0 b$ & $25,0 \pm 25,0 b$ \\
\hline ----- & 675 & ----- & $43,0 \pm 1,0 b$ & $0,0 \pm 0,0 c$ & $100,0 \pm 0,0 \mathrm{a}$ & $0,0 \pm 0,0 c$ \\
\hline ----- & 900 & ----- & $26,5 \pm 1,5 b$ & $0,0 \pm 0,0 c$ & $25,0 \pm 25,0 b$ & $75,0 \pm 25,1 a$ \\
\hline ----- & ----- & 225 & $76,5 \pm 4,5 a$ & $5,0 \pm 5,0 \mathrm{c}$ & $36,5 \pm 6,5 b$ & $58,5 \pm 1,5 a$ \\
\hline ----- & ----- & 450 & $71,5 \pm 8,5 a$ & $10,0 \pm 4,0 \mathrm{c}$ & $18,5 \pm 3,5 b$ & $71,5 \pm 0,5 a$ \\
\hline ----- & ----- & 675 & $57,0 \pm 10,0 b$ & $26,5 \pm 6,5 c$ & $63,5 \pm 3,5 a$ & $10,0 \pm 10,0 b$ \\
\hline ----- & ----- & 900 & $80,5 \pm 5,5 a$ & $0,0 \pm 0,0 \mathrm{c}$ & $66,5 \pm 33,6 a$ & $33,5 \pm 33,5 b$ \\
\hline
\end{tabular}

Médias \pm erro padrão seguidas pela mesma letra na coluna não diferem estatisticamente entre si, pelo teste de Skott-Knott a 5\% de probabilidade. Tipos de calos: 1 - pouca, 3 - média e 5 - muita formação de calo.

A adição de reguladores de crescimento do grupo das auxinas ao meio de indução tem amplo uso para a formação de calos primários e embriogênicos (Geldner et al., 2000; Fehér et al., 2003; Eshraghi et al., 2005; Portillo et al., 2007; Silva et al., 2012). 
Em Elaeis guineensis, grande parte dos trabalhos relatam a utilização de 2,4-D para a indução de embriogênese somática (Sogeke 1996). Semelhante ao verificado no presente trabalho, Rival et al. (1997) observaram a formação de calos em dendezeiro realizando o cultivo no escuro, em meio de cultura suplementado com 2,4-D. De um modo similar, Teixeira et al. (1994) obtiveram a formação de calos a partir de inflorescências jovens de E. guineensis após 2 a 3 meses de cultivo em meio de MS (Murashige \& Skoog, 1962) modificado e suplementado com 2,4-D (475 $\mu \mathrm{M})$. Embora o uso do 2,4-D para essa cultura e finalidade seja bastante conhecido, alguns trabalhos têm evidenciado a superioridade do Picloram na indução da embriogênese somática em muitas espécies de palmeiras, tais como, o dendezeiro, a pupunha, a macaúba e o açaí (Valverde et al., 1987; Karun et al., 2004; Steinmacher et al., 2007; Moura et al., 2008; Scherwinski-Pereira et al., 2010; Steinmacher et al., 2011; Scherwinski-Pereira et al., 2012).

Diversos trabalhos relatam a utilização desse grupo de reguladores com a finalidade da indução da calogênese. Em Bactris gasipaes, a formação de calos foi obtida em embriões zigóticos quando estes foram cultivados em meio de cultura contendo Picloram como fonte de auxina (Steinmacher et al., 2007). Este regulador também induziu a competência embriogênica em E. guineensis (Teixeira et al., 1995; Scherwinski-Pereira et al., 2010; Silva et al., 2012).

Segundo Almeida et al. (2012), a indução da organogênese ou da embriogênese somática de determinados explantes é um processo morfogenético que está sob a influência de reguladores de crescimento exógenos e suas interações com fitormônios endógenos. Analisando o efeito da associação de ANA com TDZ ou ANA com BAP na resposta morfogenética de Bactris gasipaes Kunth, esses autores verificaram que o uso de determinados reguladores de crescimento pode conduzir para diferentes vias morfogênicas, podendo direcionar para uma resposta organogênica ou embriogênica.

Diversos trabalhos relatam a utilização de ANA na indução da organogênese em diferentes espécies, o que permite verificar o potencial dessa auxina para promover a formação de raiz e, dessa forma, possibilitar a compreensão do surgimento de raízes observado no presente trabalho. Loiseau et al. (1995), comparando as auxinas ANA, 2,4-D e Picloram na indução da embriogênese de Pisum sativum L., também verificou uma reduzida formação de calos com a utilização de ANA e a abundante ocorrência de rizogênese. Gueye et al. (2009) relatam a utilização de ANA na indução da calogênese e da rizogênese em Phoenix dactylifera L. cv. Ahmar. 
Diferentemente do presente trabalho, Te-chato (1998) obtiveram as melhores taxas de formação de calos primários de dendezeiro, entre os tratamentos testados (2,4-D e ANA), com a utilização de $215 \mu \mathrm{M}$ de ANA. Mgbeze et al. (2015) obtiveram 8\% de formação de calo em Elaeis guineensis com a utilização de $994 \mu \mathrm{M}$ de ANA. Em quatro genótipos de Phoenix dactylifera L., Sané et al. (2012) verificaram a eficácia da utilização de ANA na formação de calos, embora isso apenas tenha ocorrido nos tratamentos em que esse regulador foi utilizado em associação com BAP, 2,4-D ou sulfato de adenina.

Outra variável analisada no presente experimento foi a influência das concentrações dos diferentes reguladores na oxidação dos explantes. Verificou-se a presença de oxidação em todos os tratamentos testados e, de forma geral, as maiores taxas de oxidação foram observadas na presença de Picloram. No entanto, a oxidação não pareceu afetar a formação de calos.

No presente trabalho, aos 2 meses de cultivo foi observado o início da oxidação dos explantes foliares. Semelhante ao verificado nesse experimento, o cultivo de diversas espécies, em altas concentrações de auxinas, apresenta oxidação dos explantes (Moura et al., 2009; Scherwinski-Pereira et al., 2010). Segundo Van Winkle et al. (2003), a ocorrência de oxidação nos tecidos inoculados se dá em resposta a algum estresse induzido pelo novo ambiente de cultivo, condição que influencia a absorção dos componentes do meio pelo explante, em virtude da obstrução do tecido oxidado. A oxidação é caracterizada pelo escurecimento das regiões excisadas dos explantes e do meio de cultivo em contato com o material vegetal oxidado. Isso ocorre devido à liberação de compostos fenólicos, precursores da síntese de lignina, pelo tecido injuriado (Van Winkle et al., 2003). O acúmulo de polifenóis e produtos de oxidação (melanina, suberina, lignina e cutina) no vacúolo das células próximas à superfície excisada, altera a composição do ambiente de cultivo e a absorção de metabólitos (Andrade et al., 2000).

A fim de reduzir a oxidação no cultivo in vitro, utiliza-se o carvão ativado, pois o mesmo pode adsorver compostos fenólicos e os seus produtos de oxidação (Teixeira et al., 1993). Para alguns autores, com a eliminação de compostos indesejáveis, o carvão ativado ajuda a promover o desenvolvimento normal das plantas in vitro, principalmente nos primeiros estágios de crescimento (Freitas et al., 2009; Souza et al., 2009; Alves et al., 2011). 


\subsubsection{Efeito do genótipo e da posição da folha}

$\mathrm{Na}$ Tabela 2, é apresentado o efeito do genótipo e da posição da folha nas médias referentes à percentagem de formação de calo primário e percentagem de oxidação na indução de calos de dendezeiro, genótipos B35-29-32, B35-29-33, B35-1733, B35-17-29, A25-15-11 e A25-14-28.

Verificou-se que as melhores taxas de formação de calos primários foram obtidas com a inoculação da parte apical de folhas imaturas em todos os genótipos testados, com a maior média de 34,1\% observada no genótipo B35-17-29. Ainda na região apical, os genótipos A25-15-11 e B35-17-33 apresentaram formação de calo de 22,3 e 25,0\% respectivamente. Já os genótipos B35-29-32, B35-29-33 e A25-14-28 apresentaram as menores taxas de formação de calo com 0,0, 0,0 e 4,2\%, respectivamente.

Quanto à oxidação dos explantes, verificou-se que, de forma geral, as maiores taxas foram observadas na região apical do palmito. Houve diferenças significativas entre os genótipos inoculados mostrando a influência genotípica na ocorrência de oxidação in vitro. Verificou-se também que a ocorrência de oxidação nos explantes não afetou a taxa de formação de calos, não sendo desfavorável, aparentemente, à resposta embriogênica. 
Tabela 2. Influência do genótipo (B35-29-32, B35-29-33, B35-17-33, B35-17-29, A2515-11 e A25-14-28) e da posição da folha (apical e basal) nas médias referentes à percentagem de formação de calo primário e percentagem de oxidação na indução de calos de dendezeiro (Elaeis guineensis Jacq.), após 180 dias de cultivo

\begin{tabular}{|c|c|c|c|c|c|}
\hline Base & Ápice & \multirow{2}{*}{$\begin{array}{l}\text { Formação de } \\
\text { calo (\%) }\end{array}$} & \multirow{2}{*}{$\begin{array}{c}\text { Calo tipo } 1 \\
(\%)\end{array}$} & \multirow{2}{*}{$\begin{array}{c}\text { Calo tipo } 3 \\
(\%)\end{array}$} & \multirow{2}{*}{$\begin{array}{c}\text { Calo tipo } 5 \\
(\%)\end{array}$} \\
\hline \multicolumn{2}{|c|}{ Genótipo } & & & & \\
\hline B35-29-32 & ------- & $0,0 \pm 0,0 c$ & ------- & ------- & ------- \\
\hline B35-29-33 & ------- & $0,0 \pm 0,0 c$ & ------- & ------- & ------- \\
\hline B35-17-33 & ------- & $0,0 \pm 0,0 \mathrm{c}$ & ------ & ------ & ------ \\
\hline B35-17-29 & ------- & $0,0 \pm 0,0 c$ & ------ & ------ & ------ \\
\hline A25-15-11 & ------- & $5,6 \pm 0,0 c$ & $25,0 \pm 25,0 c$ & $25,0 \pm 25,0 a$ & $50,0 \pm 0,0 a$ \\
\hline A25-14-28 & -------- & $0,0 \pm 0,0 \mathrm{c}$ & ------- & ------- & ------- \\
\hline ------- & B35-29-32 & $0,0 \pm 0,0 \mathrm{c}$ & ------- & ------- & ------- \\
\hline ------- & B35-29-33 & $0,0 \pm 0,0 c$ & ------ & ------ & ------ \\
\hline & B35-17-33 & $22,3 \pm 5,6 b$ & $50,0 \pm 12,5 b$ & $31,2 \pm 18,8 a$ & $18,7 \pm 6,3 b$ \\
\hline & B35-17-29 & $34,1 \pm 4,9 a$ & $91,6 \pm 8,4 a$ & $8,4 \pm 8,4 a$ & $0,0 \pm 0,0 \mathrm{c}$ \\
\hline & A25-15-11 & $25,0 \pm 1,2 b$ & $45,8 \pm 20,9 b$ & $47,9 \pm 21,0 a$ & $6,3 \pm 0,0 c$ \\
\hline ------ & A25-14-28 & $4,2 \pm 4,2 \mathrm{c}$ & $100,0 \pm 0,0 \mathrm{a}$ & $0,0 \pm 0,0 \mathrm{a}$ & $0,0 \pm 0,0 \mathrm{c}$ \\
\hline Base & Ápice & Oxidação & Oxidação & Oxidação & Oxidação \\
\hline \multicolumn{2}{|c|}{ Genótipo } & (\%) & tipo 1 (\%) & tipo 3 (\%) & tipo 5 (\%) \\
\hline B35-29-32 & ------- & $4,1 \pm 4,1 \mathrm{e}$ & $100,0 \pm 0,0 a$ & $0,0 \pm 0,0 a$ & $0,0 \pm 0,0 b$ \\
\hline B35-29-33 & ------- & $5,5 \pm 5,5 e$ & $100,0 \pm 0,0 a$ & $0,0 \pm 0,0 a$ & $0,0 \pm 0,0 b$ \\
\hline B35-17-33 & ------- & $11,8 \pm 0,7 \mathrm{e}$ & $0,0 \pm 0,0 \mathrm{c}$ & $25,0 \pm 25,0 a$ & $75,0 \pm 25,1 \mathrm{a}$ \\
\hline B35-17-29 & ------- & $55,2 \pm 10,8 c$ & $12,5 \pm 12,5 c$ & $29,1 \pm 4,2 \mathrm{a}$ & $83,3 \pm 16,7 a$ \\
\hline A25-15-11 & ------- & $93,1 \pm 7,0 \mathrm{a}$ & $62,4 \pm 4,2 b$ & $16,7 \pm 0,0 \mathrm{a}$ & $20,8 \pm 4,2 b$ \\
\hline A25-14-28 & ------- & $35,4 \pm 2,1 d$ & $47,2 \pm 2,8 b$ & $47,2 \pm 2,8 a$ & $5,5 \pm 5,5 b$ \\
\hline ------- & B35-29-32 & $0,0 \pm 0,0$ e & ------- & ------- & ------- \\
\hline & B35-29-33 & $78,5 \pm 2,5 b$ & $8,3 \pm 8,3 c$ & $16,6 \pm 16,6 a$ & $75,0 \pm 25,0 a$ \\
\hline ------- & B35-17-33 & $46,0 \pm 4,0 d$ & $5,1 \pm 5,1 c$ & $47,1 \pm 6,5 \mathrm{a}$ & $47,7 \pm 1,3 a$ \\
\hline -------- & B35-17-29 & $95,8 \pm 4,2 \mathrm{a}$ & $0,0 \pm 0,0 c$ & $41,6 \pm 8,4 a$ & $58,3 \pm 8,3 a$ \\
\hline ------- & B25-15-11 & $100,0 \pm 0,0 a$ & $7,1 \pm 7,1 \mathrm{c}$ & $22,6 \pm 8,4 \mathrm{a}$ & $70,2 \pm 1,2 \mathrm{a}$ \\
\hline ------- & B25-14-28 & $100,0 \pm 0,0 a$ & $50,0 \pm 50,0 b$ & $25,0 \pm 25,0 a$ & $25,0 \pm 25,0 \mathrm{~b}$ \\
\hline
\end{tabular}

Médias seguidas pela mesma letra não diferem estatisticamente entre si, pelo teste de Skott-Knott a $5 \%$ de probabilidade. Tipos de calos: 1 - pouca, 3 - média e 5 - muita formação de calo.

Embora a condição do cultivo influencie fortemente a resposta embriogênica, segundo Elmeer (2013), a morfogênese e o crescimento de tecidos cultivados in vitro são mais influenciados pelo genótipo do que por qualquer outro fator. De acordo com alguns autores, a frequência da indução de calos primários com competência embriogênica está inteiramente associada, não só aos genótipos utilizados, mas 
também, aos níveis de hormônios endógenos de cada explante (Carman, 1990; Jiménez, 2001).

Em relação à influência genotípica na resposta embriogênica, diversas pesquisas foram feitas visando compreender como tal fator pode atuar na morfogênese in vitro. Segundo autores, as diferenças genotípicas podem estar associadas à variações no teor de hormônios endógenos entre os genótipos. Nesse contexto, Kopertekh \& Butenko (1995) verificaram a presença de níveis mais elevados de AIA e ABA em explantes de genótipos de Triticum sp. com maior competência embriogênica. Em Daucus sp., Thi \& Pleschka (2005) verificaram que quanto maior o conteúdo endógeno de $A B A$ nos pecíolos inoculados, maior a sua capacidade embriogênica. No entanto, Jiménez \& Bangerth (2001) verificaram que não houve diferença estatística para a resposta embriogênica de dois genótipos de Hordeum vulgare L. com diferentes conteúdos de auxina endógena, sugerindo que outro fator pode estar causando as diferenças genotípicas nesta espécie.

Além da influência exercida pelos hormônios endógenos, a resposta genotípica também pode estar associada à sensibilidade de cada genótipo a reguladores de crescimento presentes no meio de cultivo (Somleva et al., 1995). Segundo Guzzo et al. (1994), essa sensibilidade pode estar relacionada com a existência de determinados receptores hormonais que variam de genótipo para genótipo, que através de sua sinalização, ativam genes específicos responsáveis pela resposta ao cultivo in vitro. De acordo com a ativação desses genes específicos, realizada a partir da presença de determinados receptores hormonais, a RNA polimerase é ativada realizando a transcrição dos genes envolvidos na regulação da divisão celular, desencadeando, assim, o processo embriogênico (Dudits et al., 1991). Essa relação entre cada genótipo e a presença de reguladores nos meios de cultivo foi claramente observada por Lo Schiavo (2000) que analisando células de Daucus carota L. verificou que o 2,4-D era capaz de modular os níveis de proteínas de ligação durante a suspensão celular.

Segundo a literatura, existe ainda a hipótese da herança genética para justificar as diferenças genotípicas no cultivo in vitro. Estudos têm demonstrado que a capacidade de resposta de algumas espécies para a embriogênese somática é hereditária e, provavelmente, controlada por pelo menos dois locus (Brown et al., 1995). Alexandrova e Conger (2002) identificaram em Dactylis glomerata, dois genes relacionados com a embriogênese somática que são indicados como DGE1 e DGE2. A análise de RNA mostrou que os DGEs foram expressos apenas em tecidos 
embriogênicos. Dessa forma, o gene DGE1 foi detectado em explantes foliares com indução da embriogênese direta e indireta, enquanto o gene DGE2 foi encontrado apenas em folhas com indução de embriogênese direta, possibilitando assim, a identificação genética da rota de desenvolvimento embriogênico. Nadolska-Orczyk e Malepszy (1989) sugeriram um determinismo genético na capacidade de regenerar plantas, a partir de embriões somáticos formados pela indução de explantes foliares de Cucumis sativus. Esses autores verificaram que dois pares de genes dominantes eram responsáveis pela regeneração de plantas in vitro. Além disso, a capacidade desses explantes foliares de regenerar plantas apresentou alta hereditariedade.

Diante desse contexto, é vasto o número de exemplos em que os resultados obtidos durante a cultura de tecidos alteraram de uma variedade de planta para outra (Stipp et al., 2001). Raimondi et al. (2001) observaram em Asparagus officinalis L. que a interação entre genótipo, tipo de explante e hora de início da cultura foram significativas para a indução de calos durante as fases iniciais de cultura. Plastira \& Perdikaris (1997) verificaram uma interação entre o genótipo e a capacidade de regeneração em Solanum lycopersicum L.. Hanzel et al. (1985) verificaram uma forte interação entre os genótipos e o meio nutritivo na indução de calos de Hordeum vulgare. Diferentes respostas genotípicas foram verificadas na indução da embriogênese somática de dendezeiro por Chehmalee \& Te-chato (2008). Sanputawong \& Te-chato (2008) observaram diferenças significativas na comparação de 16 genótipos de dendezeiro durante a indução da embriogênese somática, a partir de embriões zigóticos. Thawaro \& Te-chato (2009) observaram diferentes respostas quanto à formação de calo em seis genótipos de E. guineensis. Ao comparar nove genótipos de E. guineensis, Silva et al. (2012) também verificaram diferenças significativas quanto à formação de calo.

Elmeer (2013) ressalta ainda que, em duas variedades de uma determinada espécie, uma pode apresentar início da morfogênese em resposta a determinados tipos de reguladores de crescimento, enquanto a outra não responde até que a concentração dos reguladores seja alterada e/ou diferentes compostos do meio sejam testados. Segundo o autor, isso ocorre devido à especificidade genotípica, onde o meio nutritivo e o ambiente de cultivo, muitas vezes, precisam ser alterados para diferentes plantas de um mesmo gênero ou espécie. Embora possam ser estabelecidas metodologias gerais para cultura de tecidos vegetais, até mesmo variedades de plantas estreitamente relacionadas podem diferir em suas necessidades (Elmeer, 2013). 
Segundo George \& Edwin (1996), o melhor método de micropropagação de uma nova planta deve ser determinado pela experimentação. Sendo assim, deve-se enfatizar que a manipulação de fatores exógenos às vezes pode otimizar a embriogênese somática em genótipos pouco responsivos (Ammirato, 1989). Sendo assim, mesmo os genótipos que não apresentaram formação de calo no presente trabalho, podem ser explorados futuramente por meio da realização de modificações nas condições de cultivo a que eles foram expostos, visando otimizar a sua resposta embriogênica.

Por outro lado, ao analisar a posição da folha com maior resposta para a indução de calos, verificou-se que, de forma geral, as maiores taxas foram observadas com a inoculação da parte apical do palmito. Semelhante ao observado no presente trabalho, outros autores também verificaram a maior eficiência da região apical na indução de culturas embriogênicas, dentre eles, Gueye et al. (2009) e Sané et al. (2006) com Phoenix dactylifera L. e Meira (2015) com Acrocomia aculeata (Jacq.) Lodd. ex Mart. também comprovaram a superioridade responsiva da região apical quando comparada à região basal do palmito.

No entanto, diferentemente do observado no presente trabalho, alguns autores afirmam que, para a indução da embriogênese somática de plantas adultas, explantes retirados de tecidos menos diferenciados ou mais imaturos possuem maior capacidade de se desdiferenciarem e adquirirem competência embriogênica, proporcionando assim, maior taxa de formação de calos. Nesse contexto, Scherwinski-Pereira et al. (2010) verificaram maior formação de calo em tecidos foliares menos diferenciados. Steinmacher et al. (2007) em Bactris gasipaes também verificaram maior capacidade responsiva para a indução da calogênese com a inoculação de explantes provenientes da região mais meristemática do palmito, embora ambos os trabalhos tenham utilizado explantes tipo "TCL" provenienete de plantas germinadas in vitro. Segundo Steinmacher et al. (2011), o cultivo in vitro é fortemente influenciado pelo tipo de explante utilizado. Para esses autores, diferentes tipos de tecidos em uma mesma planta, bem como o estádio de desenvolvimento desses tecidos, podem proporcionar respostas distintas no cultivo in vitro. A hipótese que reforça esse fato é a de que a concentração de auxina endógena presente no tecido inoculado e a posição dos explantes são possivelmente fatores que afetam a resposta embriogênica (Wang et al., 2011).

Após 180 dias de cultivo foi observado, em dois genótipos testados, o surgimento de calos embriogênicos com aspecto friável, consistência pouco aquosa e 
coloração amarelada. Os genótipos B35-17-33 e B35-17-29 apresentaram, respectivamente, 13,1 e 8,6\% de formação de calo embriogênico (Figura 5 A). As diferentes taxas de formação de calos embriogênicos também evidenciaram que os genótipos de dendezeiro testados apresentam respostas distintas, mesmo quando cultivados sob condições ambientais e nutricionais semelhantes.
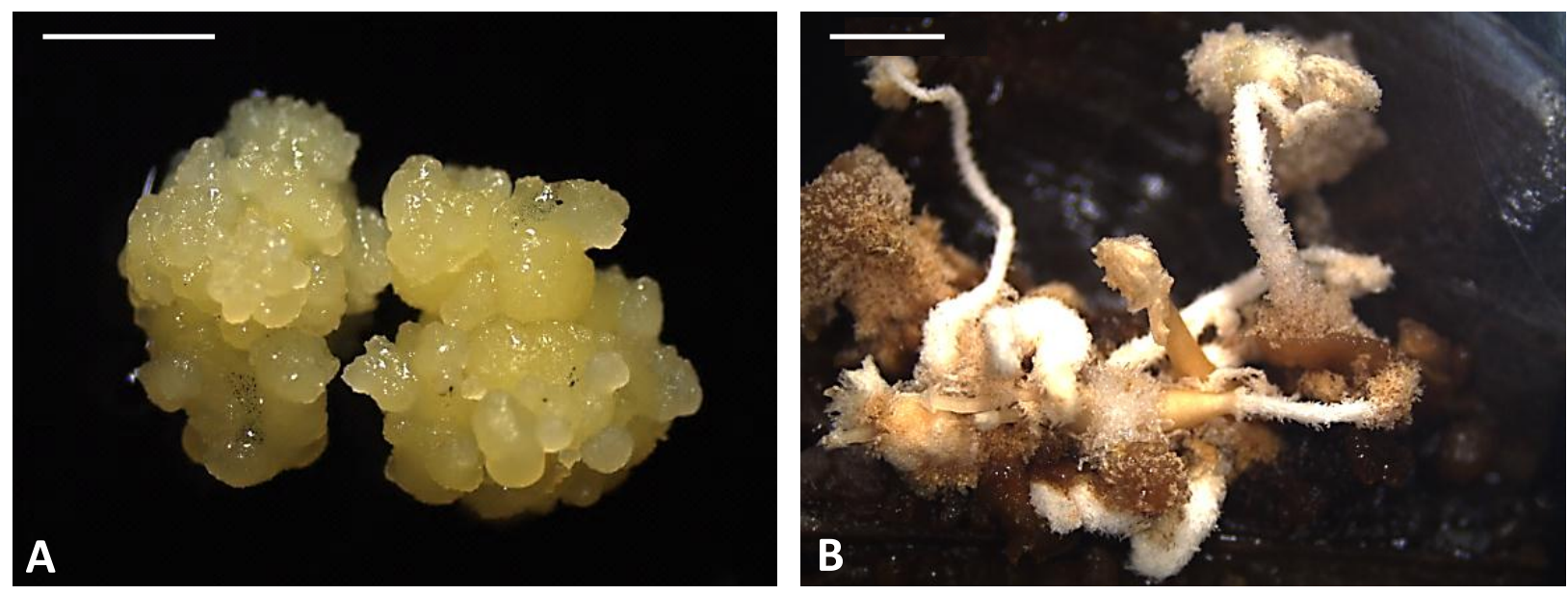

Figura 5. Caracterização morfológica de calos embriogênicos $(A)$ formados em meio de indução, contendo $225 \mu \mathrm{m}$ de Picloram e raízes (B) formadas em meio de indução, contendo $900 \mu \mathrm{m}$ de ANA. Indução realizada a partir da inoculação de folhas jovens de dendezeiro (Elaeis guineensis Jacq.). Barras: A. 2,0 mm, B. 5,0 cm.

Aspectos diferenciados de calos embriogênicos são encontrados na literatura. Scherwinski-Pereira et al. (2010) avaliaram a indução de calos primários e embriogênicos formados a partir de uma fina camada de células de tecidos foliares imaturos de dendezeiro. Esses autores relatam a presença de calos primários com aspecto translúcido e coloração amarelada e calos embriogênicos com aspecto friável. Já Pádua et al. (2013), por meio da indução de calos a partir de folhas imaturas de dendezeiro, apresentaram a formação de quatro diferentes tipos de calos. Segundo esses autores, a formação de massas celulares não ocorre de forma homogênea. Eles classificaram os calos de acordo com a cor e a consistência de cada um: tipo 1 alongado e translúcido, tipo 2 - desigual e translúcido, tipo 3 - globular com coloração bege e tipo 4 - globular com coloração branca.

Moura et al. (2008) observaram dois tipos de calo na indução da embriogênese somática a partir de embriões zigóticos em Acrocomia aculeata: o calo tipo I com 
aspecto esponjoso e coloração esbranquiçada e o calo tipo II com aspecto nodular e coloração amarelada. Para esses autores, somente o calo tipo II foi considerado embriogênico, isso porque esse tipo de calo foi caracterizado pela presença de células pequenas, com citoplasma denso e núcleo com nucléolo evidente que representam zonas meristemáticas que poderiam levar ao desenvolvimento de embriões somáticos.

Assim como verificado no presente trabalho, podem ser observadas diferentes respostas genotípicas dentro de uma espécie, quanto à capacidade de formação de calos embriogênicos. Sanputawong \& Te-chato (2008) observaram diferenças significativas na comparação de 16 genótipos de dendezeiro durante a indução da embriogênese somática a partir de embriões zigóticos. Esses autores observaram que, após 90 dias de cultivo, apenas um genótipo dos 16 testados apresentou maior percentagem de formação de calos, com média de 33,3\%. Diante disso, independente da variável analisada (calo primário, oxidação ou calo embriogênico), verifica-se a forte influência genotípica na resposta embriogênica de uma determinada espécie.

\subsection{Multiplicação de calos}

Verificou-se que o maior ganho de biomassa fresca (989\%) foi observado com a multiplicação de calos embriogênicos em meio líquido em agitação (Figura 6). De forma geral, a multiplicação de calos embriogênicos apresentou os maiores acúmulos de biomassa quando comparado ao calo primário, independente da consistência do meio de cultivo. Não foram verificadas diferenças significativas na multiplicação do calo primário nos tipos de meio utilizados. Quanto ao tempo de cultivo, verificou-se que a multiplicação dos calos ocorreu a partir dos 30 dias de cultivo, embora as maiores percentagens tenham sido observadas, de forma geral, aos 90 dias de cultivo (Tabela $3)$. 
Tabela 3. Influência do tipo de calo (calo primário ou embriogênico) e consistência do meio de cultivo (meio líquido ou sólido) no ganho de biomassa fresca (\%) durante a multiplicação de calos de dendezeiro (Elaeis guineensis Jacq.) obtidos de folhas imaturas

\begin{tabular}{ccccc}
\hline \multicolumn{4}{c}{ Acúmulo de biomassa fresca (\%) } \\
\hline Calo / Meio & & 30 dias & $\begin{array}{c}\text { Tempo de cultivo } \\
\mathbf{6 0} \text { dias }\end{array}$ & $\mathbf{9 0}$ dias \\
\cline { 2 - 5 } Calo Primário & Sólido & $200 \pm 11 \mathrm{aA}$ & $286 \pm 28 \mathrm{bA}$ & $405 \pm 30 \mathrm{cA}$ \\
Calo Embriogênico & Sólido & $297 \pm 18 \mathrm{aB}$ & $459 \pm 44 \mathrm{aB}$ & $736 \pm 163 \mathrm{bA}$ \\
Calo Primário & Líquido & $131 \pm 8 \mathrm{aB}$ & $250 \pm 17 \mathrm{bB}$ & $422 \pm 51 \mathrm{cA}$ \\
Calo Embriogênico & Líquido & $273 \pm 10 \mathrm{aC}$ & $540 \pm 72 \mathrm{aB}$ & $989 \pm 94 \mathrm{aA}$ \\
\hline
\end{tabular}

Médias \pm erro padrão seguidas pela mesma letra, maiúscula na horizontal e minúscula na horizontal, não diferem estatisticamente entre si pelo teste de Skott Knott a 5\% de probabilidade.

Diferentes estudos relatam a superioridade da multiplicação de culturas embriogênicas em meio líquido. Semelhante ao verificado no presente trabalho, Steinmacher et al. (2011) também verificaram que, na multiplicação de propágulos de Bactris gasipaes, os maiores acúmulos de biomassa fresca foram encontrados com a utilização de meio líquido.

Diversos autores também relataram que a utilização de meio líquido foi realizada com sucesso na multiplicação de calos de Elaeis guineensis. Gorret et al. (2004), multiplicando calos de dendezeiro em meio líquido obtiveram um aumento de biomassa de cerca $250 \%$ a cada 30 dias de cultivo. Tarmizi et al. (2004) verificaram uma taxa de multiplicação de calos de dendezeiro de $122 \%$ aos 30 dias, $200 \%$ aos 60 dias e $252 \%$ aos 80 dias de cultivo. Choi et al. (2008) apresentaram um aumento de biomassa de aproximadamente $260 \%$ ao final de 30 dias de cultivo. De acordo com Marbun et al. (2015), durante a etapa de multiplicação, a biomassa fresca dos calos de Elaeis guineensis pode aumentar em até $600 \%$ ao final de 60 dias de cultivo em meio líquido em sistema de imersão temporária. 

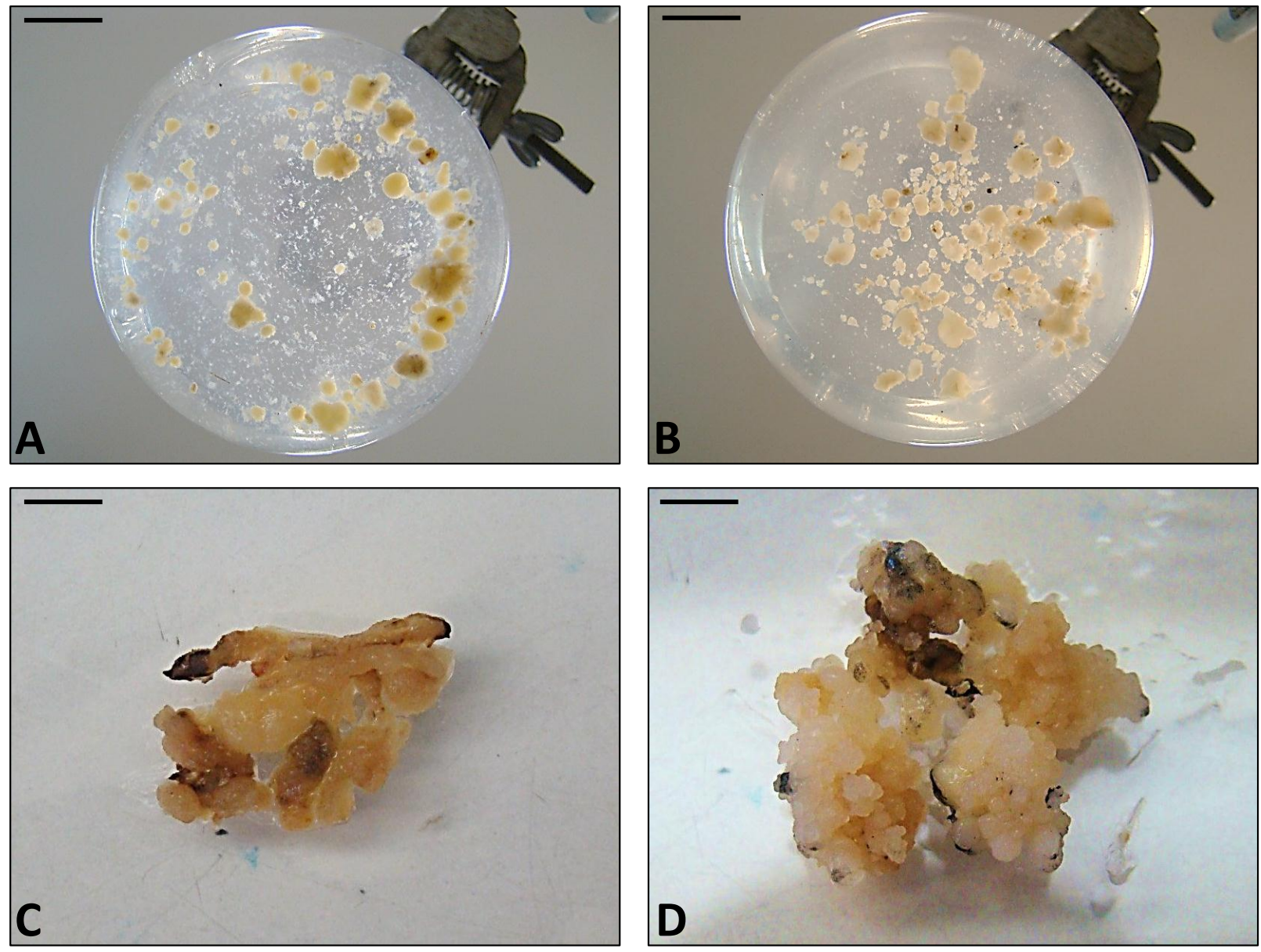

Figura 6. Multiplicação de calos primários e embriogênicos de dendezeiro (Elaeis guineensis Jacq.) após 90 dias de cultivo, obtidos a partir de folhas imaturas. A. Multiplicação de calo primário em meio líquido. B. Multiplicação de calo embriogênico em meio líquido. C. Multiplicação de calo primário em meio sólido $D$. Multiplicação de calo embriogênico em meio sólido. Barras: A. 0,7 cm; B. 0,9 cm; D. 1,0 cm; E. 1,0 cm.

Heringer et al. (2014), após 45 dias de cultivo, partindo de $1 \mathrm{~g}$ de massa fresca de culturas embriogênicas de Bactris gasipaes, obtiveram na multiplicação em meio sólido e líquido 6,2 e 13,2 g de massa fresca, respectivamente. No entanto, esses autores verificaram que parte do acúmulo de massa fresca observado no meio sólido se deveu à alta proliferação de estruturas esponjosas, caracterizadas por serem não embriogênicas. Analisando comparativa e histoquimicamente as células suspensas no meio nutritivo após 90 dias de cultivo em meio de multiplicação foi verificado que, conforme as células foram se aglomerando e se reorganizando, estas foram adquirindo competência embriogênica (Figura 7). 

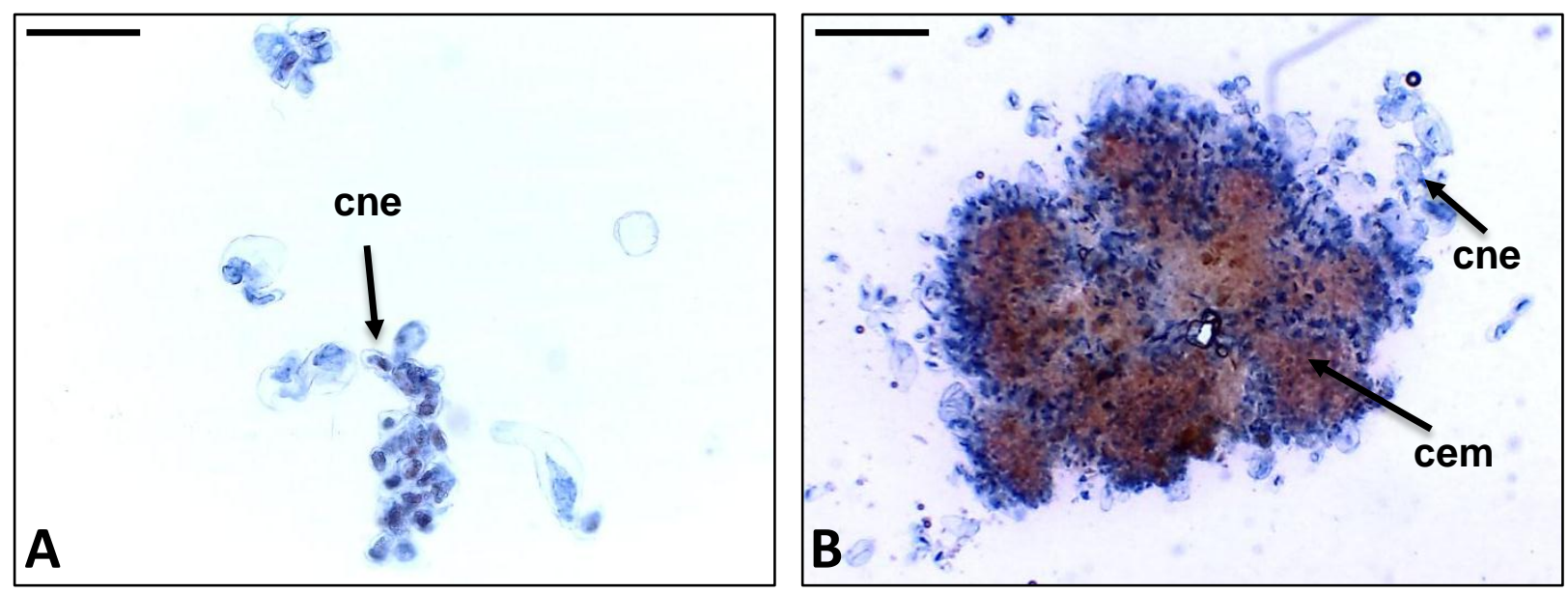

Figura 7. Teste histoquímico de calos primários e embriogênicos de dendezeiro (Elaeis guineensis Jacq.) multiplicados em meio líquido usando azul de Evans e carmim acético, após 90 dias de cultivo. A. Células não embriogênicas dispersas no meio nutritivo coradas de azul; B. Início de aglomeração celular com presença de células embriogênicas, coradas de vermelho e células não embriogênicas coradas de azul. Abreviações: cem = células embriogênicas; $c n e=$ células não embriogênicas. Barras: A-B. $0,2 \mathrm{~mm}$.

Segundo Choi et al. (2008), a utilização de meio líquido na multiplicação de culturas embriogênicas proporciona maior disponibilidade de nutrientes e reguladores de crescimento para as culturas. Esses autores também relatam que o efeito da agitação do meio nutritivo durante 0 cultivo promove 0 aumento nas taxas de $\mathrm{O}_{2}$ dissolvido no meio de cultivo. Essas condições aumentam o potencial dos propágulos de metabolizar a sacarose contida no meio nutritivo, possibilitando assim, a otimização do acúmulo de biomassa (Choi et al., 2008).

\subsection{Diferenciação, regeneração, enraizamento/alongamento e aclimatização}

Ao final da etapa de multiplicação, os calos foram então cultivados por 180 dias em meios de diferenciação. Após esse período, constatou-se a presença de uma pequena quantidade de calos primários com formação de embriões somáticos, em média cerca de $5 \%$. Por outro lado, foi verificado o desenvolvimento de embriões somáticos em praticamente $100 \%$ dos calos embriogênicos (Figura 8 A-B). 

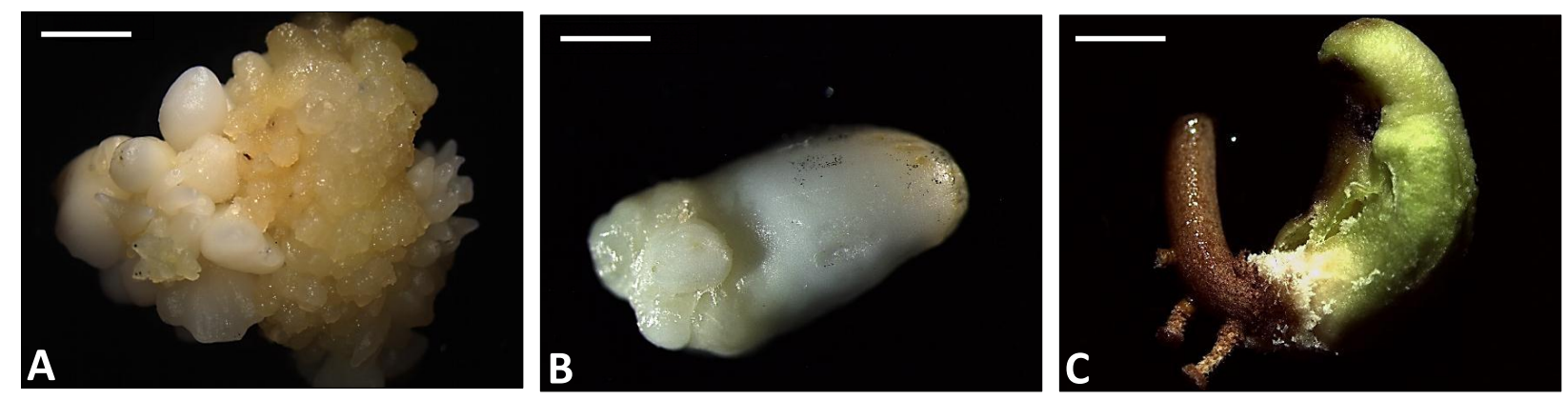

Figura 8. Aspectos morfológicos dos cultivos durante as etapas de diferenciação de embriões somáticos (A-B) e regeneração de plantas $(C)$ de dendezeiro (Elaeis guineensis Jacq.). Barras: A. 2,0 mm; B. 1,2 mm; C. 2,0 mm.

Em seguida, os embriões somáticos em estádio de torpedo (Figura 8 B) foram cultivados por até seis subcultivos de 30 dias em meios de MS isentos de reguladores de crescimento. Nesse processo, observou-se que apenas 1\% destes propágulos regeneraram plantas completas (Figura $8 \mathrm{C}$ ), ou seja, cultivos com a parte aérea e o sistema radicular desenvolvidos. No restante dos casos, foi constatada a regeneração de brotações desprovidas de raízes com alturas de até $2,5 \mathrm{~cm}$.

Por fim, as culturas regeneradas foram submetidas a uma etapa complementar de enraizamento/alongamento (Figura $9 \mathrm{~A}$ ) em meio de MS acrescido de 53,7 $\mu \mathrm{M}$ de AIB, e então aclimatizadas em casa de vegetação (Figura $9 \mathrm{~B}$ ), onde as taxas de sobrevivência dos propágulos atingiram valores próximos a $80 \%$. Tal resultado demonstra que os calos obtidos a partir da embriogênese somática de folhas imaturas de plantas adultas de dendezeiro originam embriões somáticos aptos para a regeneração de plantas. 

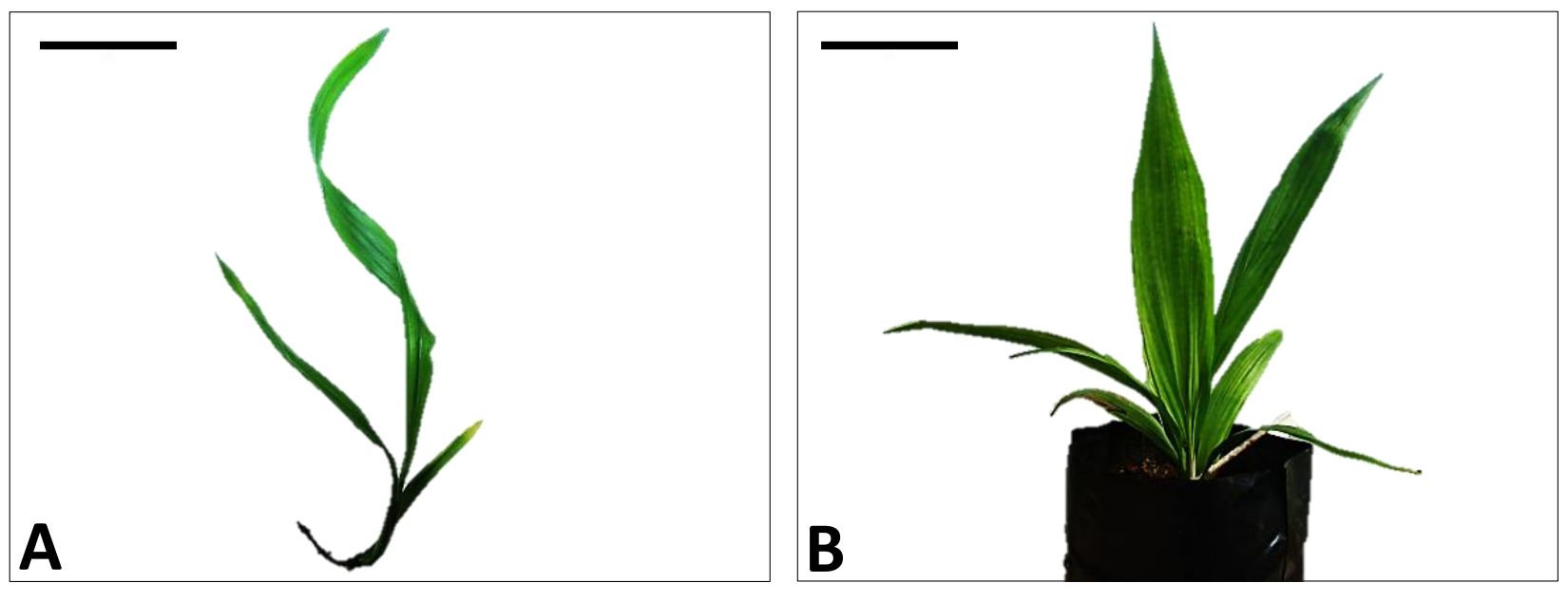

Figura 9. Aspectos morfológicos dos cultivos durante a etapa enraizamento/alongamento dos regenerantes $(A)$ e aclimatização das mudas $(B)$ de dendezeiro (Elaeis guineensis Jacq.). Barras: A. 4,0 cm; B. 11,7 cm. 


\section{CONCLUSÕES}

$\mathrm{Na}$ etapa de indução da embriogênese somática de dendezeiro a partir de folhas imaturas de plantas adultas, verifica-se, de forma geral, que o Picloram proporciona as melhores taxas de formação de calos. Não é verificada a indução de calos sem a presença de auxinas no meio de cultura. Com a utilização de ANA nessa etapa, verifica-se a indução da rizogênese associada à baixa ou mesmo nula taxa de formação de calos. Já a utilização de 2,4-D, embora proporcione uma formação de calo significativamente similar a da verificada no Picloram, proporciona calos qualitativamente inferiores quanto ao potencial embriogênico. Verifica-se que essa etapa do cultivo é genótipo-dependente. De forma geral, a oxidação não influencia negativamente a calogênese. Na etapa de multiplicação, calos embriogênicos apresentam maior acúmulo de biomassa fresca, principalmente quando o meio líquido sob agitação é utilizado no processo. 


\section{REFERÊNCIAS BIBLIOGRÁFICAS}

ALEXANDROVA, K. S.; CONGER, B. V. Isolation of two somatic embryogenesisrelated genes from orchardgrass (Dactylis glomerata). Plant Science, v.162, p.301307, 2002.

ALMEIDA, M.; ALMEIDA, C. V.; GRANER, E. M.; BRONDANI, G. E.; ABREU-TARAZI, M. F. Pre-procambial cells are niches for pluripotent and totipotent stem-like cells for organogenesis and somatic embryogenesis in the peach palm: a histological study. Plant Cell Report, v.31, p.1495-1515, 2012.

ALVES, S. A. O.; LEMOS, O. F.; SILVA, A. L. L. In vitro protocol optimization for development of interspecific hybrids of oil palm (Elaeis oleifera (HBK) Cortés $x$ Elaeis guineensis Jacq.). Journal of Biotechnology and Biodiversity, v.2, p.1-6, 2011.

AMMIRATO, P. V. Recent progress in somatic embryogenesis. International Association of Peacekeeping Training Centres, v.57, p.2-16 1989.

ANDRADE, M. W.; LUZ, J. M. Q.; LACERDA, A. S. Micropropagação da aroeira (Myracroduon urundeuva Fr. All.). Ciência e Agrotecnologia, v.24, p.174-180, 2000.

BALZON, T.A.; Gomes Luis, Z.; Scherwinsky-Pereira, J.E. New approaches to improve the efficiency of somatic embryogenesis in oil palm (Elaeis guineensis Jacq.) from mature zygotic embryos. In Vitro Cell Development Biology Plant. v. 49, 41-50, 2013.

BROWN, D. C. W.; FINSTAD, K. I.; WATSON, E. M. Somatic embryogenesis in herbaceous dicots. In: In vitro Embryogenesis in plants. (T. A. Thorpe-Ed.). Kluwer Academic Publishers. p. 345-415, 1995.

CARMAN, J. G. Embryogenic cells in plant tissue cultures: occurrence and behavior. In Vitro Cell \& Developmental Biology, v.26, p.746-753, 1990.

CHANPRASERT, W.; MYINT, T.; SRIKUL, S.; WONGSRI, O. Effects of neonicotinoid and method of breaking dormancy on seed germination and seedling vigour of oil palm (Elaeis guineensis Jacq.). Journal of Oil Palm Research, v.24, p.1227-1234, 2012.

CHEHMALEE, S.; TE-CHATO, S. Induction of somatic embryogenesis and plantlet regeneration from cultured zygotic embryo of oil palm. Journal of Agricultural Technology, v.4, p.137-146, 2008.

CHOI, D. S.; ANDRADE, M. H. C.; WILLIS, L. B.; CHO, C. W.; SCHOENHEIT, J.; BOCCAZZI, P.; SAMBANTHANMURTHI, R.; SINSKEY, A. J.; RHA, C. K. Effect of agitation and aeration of yield optimization of oil palm suspension culture. Journal of Palm Oil Research , v.1, p.23-34, 2008.

CONSTANTIN, M.; NCHU, W. A.; GODSWILL, N. N.; WIENDI, N. M. A.; WACHJAR, A.; FRANK, N. E. G. Induction of oil palm (Elaeis guineensis Jacq. var. Tenera) callogenesis and somatic embryogenesis from young leaf explants. Journal of Applied Biology and Biotechnology, v.3, p.4-10, 2015. 
CORLEY, R. V. H.; BARRET, J. N.; JONES, L. H. Vegetative propagation of oil palm via tissue culture. Oil Palm News, v.22, p.2-7, 1977.

DUDITS, D.; BOGRE, L.; GYORGYEY, J. Molecular and cellular approaches to the analysis of plant embryo development from somatic cell in vitro. Journal of Cell Science, v.99, p.473-482, 1991.

DURAND-GASSELIN, T.; GUEN, V.; KONAN, K.; DUVAL, Y. Oil palm (Elaeis guineensis Jacq.) plantations in Ivory Coast obtained through in vitro culture. First results. Oléagineux, v.45, p.1-11, 1990.

DURZAN, D. J. Somatic polyembryogenesis for the multiplication of tree crops. Biotechnology and Genetic Engineering Reviews, v.6, p.341-378, 1988.

DUVAL, Y.; DURAND-GASSELIN, T.; KONAN, K. C. In vitro vegetative propagation of oil palm (Elaeis guineensis Jacq.). Oleagineux, v.43, p.145-47, 1988.

DUVAL, Y.; ENGELMANN, F.; DURAND-GASSELIN, T. Somatic embryogenesis in oil palm (Elaeis guineensis Jacq). 1995 In: Biotechnology in Agriculture and Forestry: Somatic Embryogenesis and Synthetic Seed, Y.P.S. Bajaj (Eds.), p.335-352, 1995.

ELMEER, K. E. S. Factors regulating somatic embryogenesis in plants. In: ASLAM, J.; SRIVASTAVA, P. S.; SHARMA, M. P. (Eds.) Somatic embryogenesis and gene expression. New Delhi: Narosa Publishing House, p.56-81, 2013.

ESHRAGHI, P.; ZARGHAMI, R.; OFOGHI, H. Genetic stability of micropropagated plantlets in date palm. Journal of Sciences, Islamic Republic of Iran, v.16, p.311-315, 2005.

FEHÉR, A.; PASTERNAK, T. P.; DUDITS, D. Transition of somatic plant cells to an embryogenic state. Plant Cell, Tissue and Organ Culture, v.74, p.201-228, 2003.

FERREIRA, D. F. Análises estatísticas por meio do SISVAR para Windows versão 4.4. Reunião anual da região brasileira da sociedade internacional de biometria, São Carlos, v.45, p.255-258, 2011.

FREITAS, R. M. O.; OLIVEIRA, M. K. T.; DOMBROSKI, J. L. D.; CÂMARA, F. A. A. Efeito dos tratamentos de oxidação em Aloysia virgata. Revista Caatinga, v.22, p.151154, 2009.

GELDNER, N.; HAMANN, T.; JURGENS, G. Is there a role for auxin in early embryogenesis? Plant Growth Regulation. v.32, p.187-191, 2000.

GEORGE, EDWIN F. Plant propagation by tissue culture. Part 1: the technology. 2 ed Edington: Exegectis, p.1361, 1996.

GOMES, J. R.; RUI, A.; LOPES, R.; CUNHA, R. N. V.; PINA, A. J. A.; SILVA, M. P.; RESENDE, M. D. V. Características vegetativas na fase juvenil de híbridos interespecíficos de caiaué com dendezeiro. Revista de Ciências Agrárias / 
Amazonian Journal of Agricultural and Environmental Sciences, v. 58, p. 27-35, 2015.

GOMES, H. T.; BARTOS, P. M. C.; BALZON, T. A.; SCHERWINSKI-PEREIRA, J. E. Regeneration of somatic embryos of oil palm (Elaeis guineensis) using temporary immersion bioreactors. Industrial Crops and Products, v.89, p.244-249, 2016.

GORRET, N.; ROSLI, S. K. B.; OPPENHEIM, S. F.; WILLIS, L. B.; LESSARD, P. A.; RHA, C.; SINSKEY, A. J. Bioreactor culture of oil palm (Elaeis guineensis) and effects of nitrogen source, inoculums size, and conditioned medium on biomass production. Journal of Biotechnology, v.108, p.253-263, 2004.

GUEYE, B.; MORCILLO, F.; COLLIN, M.; GARGANI, D.; OVERVOORDE, P.; ABERLENC-BERTOSSI, F.; VERDEIL, J. L. Acquisition of callogenic capacity in date palm leaf tissues in response to 2, 4-D treatment. Plant Cell, Tissue and Organ Culture, v.99, p.35-45, 2009.

GUZZO F., BALDAN B., MARIANI P., LO SCHIAVO F., TERZI M. Studies on the origin of totipotent cells in explants of Daucus carota L. Journal of Experimental Botany, v,45, p.1427-1432, 1994.

HANZEL, J. J.; MILLER, J. P.; BRINKMAN, M. A.; FENDOS, E. Genotype and media effects on callus formation and regeneration in barley. Crop Science, v.25, p.27-31. 1985.

HERINGER, A.S.; STEINMACHER, D.A.; FRAGA, H.P.F.; VIEIRA, L.N.; MONTAGNA, T.; QUINGA, L.A.P.; QUOIRIN, M.G.G.; JIMÉNEZ, V.M.; GUERRA, M.P. Improved high-efficiency protocol for somatic embryogenesis in Peach Palm (Bactris gasipaes Kunth) using RITA® temporary immersion system. Scientia Horticulturae, v.179, p.284-292, 2014.

INPUAY, K.; TE-CHATO, S. Primary and secondary somatic embryos as tool for the propagation and artificial seed production of oil palm. Journal of Agricultural Technology, v.8, p.597-609, 2012.

JAYANTHI, M.; SUSANTHI, B.; MOHAN, N. M.; MANDAL, P. K. In vitro somatic embryogenesis and plantlet regeneration from immature male inflorescence of adult dura and tenera palms of Elaeis guineensis (Jacq.). SpringerPlus, v.4, p.256-262, 2015.

JIMÉNEZ, V. M.; BANGERTH, F. In vitro culture and endogenous hormone levels in immature zygotic embryos, endosperm and callus cultures of normal and high-lysine barley genotypes. Journal of Applied Botany and Food Quality, v.75, p.1-7, 2001.

JIMÉNEZ, V. M. Regulation of in vitro somatic embryogenesis with emphasis on the role of endogenous hormones. Revista Brasileira de Fisiologia Vegetal, v.13, p.196-223, 2001.

JIMÉNEZ, V. M. Involvement of plant hormones and plant growth regulators on in vitro somatic embryogenesis. Plant Growth Regulation, v.47, p.91-110, 2005. 
JOUANNIC, S.; LARTAUD, M.; HERVÉ, J.; COLLIN, M.; ORIEUX, Y.; VERDEIL, J. L.; TREGEAR, J. W. The shoot apical meristem of oil palm (Elaeis guineensis; Arecaceae): developmental progression and dynamics. Annals of Botany, v.108, p.1477-1487, 2011.

KARUN, A.; SIRIL, E. A.; RADHA, E.; PARTHASARATHY, V. A. Somatic embryogenesis and plantlet regeneration from leaf and inflorescence explants of arecanut (Areca catechu L.). Current Science, v.86, p.25, 2004.

KHAW, C. H.; NG, S. K. Performance of commercial scale clonal oil palm (Elaeis guineensis Jacq.) plantings in Malaysia. Acta Horticulturae, v.461, p.251-258, 1998.

KONAN, K.E.; Duran-Gasselin, T.; Kouadio, Y.J.; Rival, A. A modeling approach of the in vitro of palm (Elaeis guineensis Jacq.) somatic embryos. Plant Cell Tissue and Organ Culture. v. 84, 99-112, 2006.

KONAN, K. E.; DURAND-GASSELIN, T.; KOUADIO, Y. J.; FLORI, A.; RIVAL, A.; DUVAL, Y.; PANNETIER, C. In Vitro conservation of oil palm somatic embryos for 20 years on a hormone-free culture medium: characteristics of the embryogenic cultures, derived plantlets and adult palms. Plant Cell Reports, v.29, p.1-13, 2010.

KOPERTEKH, L.G.; BUTENKO, R.G. Naturally occurring phytohormones in wheat explants as related to wheat morphogenesis in vitro. Russian Journal of Plant Physiology, v.42, p.488-491, 1995.

LELJAK-LEVANIĆ, D.; MIHALJEVIĆ, S.; BAUER, N. Somatic and zygotic embryos share common developmental features at the onset of plant embryogenesis. Acta Physiologiae Plantarum, v.37, p.1-14, 2015.

LO SCHIAVO, F.; BALDAN, B.; COMPAGNIN, D.; GANZ, R.; MARIANI, P.; TERZI, M. Spontaneous and induced apoptosis in embryogenic cell cultures of carrot (Daucus carota L.) in different physiological states. European Journal of Cell Biology, v.79, p.294-298, 2000.

LOISEAU, J.; CLAIRE, M.; YVON, L. D. Effects of auxins, cytokinins, carbohydrates and amino acids on somatic embryogenesis induction from shoot apices of pea. Plant Cell, Tissue and Organ Culture, v.41, p.267-275, 1995.

MARBUN, C. L. M.; TORUAN-MATHIUSA, N.; REFLINIA; UTOMOA, C.; LIWANG, T. Micropropagation of embryogenic callus of oil palm (Elaeis guineensis Jacq.) using temporary immersion system. Procedia Chemistry, v.14, p.122-129, 2015.

MARTINE, B.M.; LAURENT, K.K.; PIERRE, B.J.; EUGÈNE, K.K.; HILAIRE, K.T.; JUSTIN, K.Y. Effect of storage and heat treatments on the germination of oil palm (Elaeis guineensis Jacq.) seed. African Journal of Agricultural Research, v.4, p.931937, 2009.

MEIRA, F. S. Embriogênese somática em macaúba (acrocomia aculeata (jacq.) lodd. ex mart.) a partir de tecidos foliares de plantas adultas Dissertação (mestrado) - Universidade de Brasília, Instituto de Ciências Biológicas, Departamento de Botânica, 2015. 
MGBEZE, G.; HAKEEM S.; ISERHIENRHIEN, A. "RAP2. 6L mRNA Level in Oil Palm (Elaeis guineensis) Leaf, Inflorescence Explants and Calli Produced From Them. The FASEB Journal 29, v.1, p.562-568, 2015.

MOURA, E. F.; MOTOIKE, S. Y.; VENTRELLA, M. C.; JÚNIOR SÁ, A. Q.; CARVALHO, $M$. Somatic embryogenesis in macaw palm (Acrocomia aculeata) from zygotic embryos. Scientia Horticulturae, v.119, p.447-454, 2009.

MOURA, E. F.; VENTRELLA, M. C.; MOTOIKE, S. Y.; JUNIOR, A. Q. S.; CARVALHO, M.; MANFIO, C. E. Histological study of somatic embryogenesis induction on zygotic embryos of macaw palm (Acrocomia aculeate (Jacq.) Lodd. ex Martius). Plant Cell, Tissue and Organ Culture, v.95, p.175-184, 2008.

MURASHIGE, T.; SKOOG, F. A revised medium for rapid growth and bioassays with tobacco tissue cultures. Physiology Plant, v.15, p.437-497, 1962.

MYINT, T.; CHANPRASERT, W.; SRIKUL, S. Germination of seed of oil palm (Elaeis guineensis Jacq.) as affected by different mechanical scarification methods. Seed Science and Technology, v.38, p.635-345, 2010.

NADOLSKA-ORCZYK, A.; MALEPSZY, S. In vitro culture of Cucumis sativus L., 7. Genes controlling plant regeneration. Theoretical and Applied Genetics, v.78, p.836840, 1989.

OOI, S.E.; Novak, O.; Dolezal, K.; Ishak, Z.; Ong-Abdullah, M.O. Cytokinin Differences in In Vitro Cultures and inflorescences from Normal and Mantled oil palm (Elaeis guineensis Jacq.). Journal of Plant Growth Regulation. 1-10, 2013.

PÁDUA, M. S.; PAIVA, L. V.; LABORY, C. R. G.; ALVES, E.; STEIN, V. C. Induction and characterization of oil palm (Elaeis guineensis Jacq.) pro-embryogenic masses. Anais da Academia Brasileira de Ciências, v.85, p.1545-1556, 2013.

PALANYANDY, S.R.; Suranthran, P.; Gantait, S.; Sinniah, U.R.; Subramaniam, S.; Abdul Aziz, M.; Alwee, S.S.R.A.; Roowi, S.A. In vitro developmental study of oil palm (Elaeis guineensis Jacq.) polyembryoids from cell suspension using scanning electron microscopy. Acta Physiology Plant Journal. 35, 1727 -1733, 2013.

PANNETIER, C.; ARTHUIS, P.; LIEVOUX, D. Néoformation de jeunes plantes d' Elaeis guineensis à partir de cals primaires obtenus sur fragments foliaires cultivés in vitro. Oléagineux, v.36, p.119-122, 1981.

PLASTIRA, V. A.; PERDIKARIS, A. K. Effect of genotype and explant type in regeneration frequency of tomato in vitro. Acta Horticulturae, p.231- 234, 1997.

PORTILLO, L.; SANTACRUZ-RUVALCABA, F.; GUTIÉRREZ-MORA, A.; RODRÍGUEZGARAY, B. Somatic embryogenesis in Weber cultivar azul. In Vitro Cellular \& Developmental Biology - Plant, v.43, p.569-575, 2007.

RABÉCHAULT, H.; MARTIN, J.P. Multiplication végétative du palmier a huile (Elaeis guineensis Jacq.) a l'aide de cultures de tissus folaires. Comptes Rendus 
Hebdomadaires des Séances de l'Academie des Sciences. v.285, p.1735-1737, 1976.

RAIMONDI, J. P.; CAMADRO, E. L.; BABINEC, F. J. Somatic embryogenesis in Asparagus officinalis L. Cv. Argenteuil: interactions between genotype, explant type and growth regulators on callus induction, growth and embryogenic differentiation. Biocell: official journal of the Sociedades Latinoamericanas de Microscopia Electronical, v.25, p.147-154, 2001.

RAJESH, M.K.; Radha, E.; Karun, A.; Parthasarathy, V.A. Plant regeneration from embryo-derived callus of oil palm-the effects of exogenous polyamines. Plant Cell Tissue and Organ Culture. V.75, p.41-47, 2003.

RIVAL, A.; ABERLENC, F.; MORCILLO, F.; TREGEAR, J.; VERDEIL, J. L.; DUVAL, Y. Scaling-up in vitro clonal propagation through somatic embryogenesis: the case of oil palm (Elaeis guineensis Jacq.). Plant Tissue Culture and Biotechnology, v.3, p.7482, 1997.

SANÉ, D.; ABERLENC-BERTOSSI, F.; GASSAMA-DIA, Y. K.; SAGNA, M.; TROUSLOT, M. F.; DUVAL, Y.; BORGEL, A. Histocytological analysis of callogenesis and somatic embryogenesis from cell suspensions of date palm (Phoenix dactylifera). Annals of Botany, v.98, v.301-308, 2006.

SANÉ, D.; ABERLENC-BERTOSSI, F.; DIATTA, L. I. D.; GUÈYE, B.; DAHER, A.; SAGNA, M.; DUVAL, Y.; BORGEL, A. Influence of growth regulators on callogenesis and somatic embryo development in date palm (Phoenix dactylifera L.) Sahelian cultivars. The Scientific World Journal, DOI:10.1100/2012/837395, 2012.

SANPUTAWONG, S.; TE-CHATO, S. Effect of genotypes of oil palm as indicator for speed of callus and embryogenic callus formation. Journal of Agricultural Science and Technology, v.4, p.147-56, 2008.

SCHERWINSKI-PEREIRA, J. E.; GUEDES, R. S., SILVA, T. L.; FERMINO, J. P.; COSTA, F. S. Somatic embryogenesis and plant regeneration from oil palm thin cell layer. In Vitro Cellular and Development Biology, v.46, p.378-385, 2010.

SCHERWINSKI-PEREIRA, J. E.; GUEDES, R. S.; SILVA, R. A.; POETA, P. C.; FERMINO, J. R. P. C. P.; LUIS, Z. G.; FREITAS, E. O. Somatic embryogenesis and plant regeneration in açaí palm (Euterpe oleracea). Plant Cell, Tissue and Organ Culture, v.109, p.501-508, 2012.

SILVA, R. C.; LUIS, Z. G.; SCHERWINSKI-PEREIRA, J. E. Differential responses to somatic embryogenesis of different genotypes of Brazilian oil palm (Elaeis guineensis Jacq.). Plant Cell, Tissue and Organ Culture, DOI 10.1007/s11240-012-0170-5, 2012.

SOGEKE, A. K. Rapid callus proliferation, somatic embryogenesis and organogenesis of oil palm (Elaeis guineensis Jacq.). Journal Elaeis Volume 8, v.2, p.92-103, 1996. 
SOMLEVA, M. M.; KAPCHINA, V.; ALEXIEVA, V.; GOLOVINSKY, E. Anticytokinin effects on in vitro response of embryogenic and nonembryogenic genotypes of Dactylis glomerata L. Plant Growth Regulation, v.16, p.109-112, 1995.

SOUZA, R. S.; CARVALHO, S. M. L.; GARCIA JUNIOR, M. R. L.; SENA, R. S. F., Adsorção de cromo (VI) por carvão ativado granular de soluções diluídas utilizando um sistema batelada sob pH controlado. Revista Acta Amazônica, v.39, p.661-668, 2009.

STARITSKY, G. Tissue culture of the oil palm (Elaeis guineensis Jacq.) as a tool for its vegetative propagation. Euphytica, v.19, p.288-292, 1970.

STEINMACHER, D. A.; KROHN, N. G.; DANTAS, A. C.; STEFENON, V. M.; CLEMENT, C. R.; GUERRA, M. P. Somatic embryogenesis in peach palm using the thin cell layer technique: induction, morpho-histological aspects and AFLP analysis of somaclonal variation. Annals of Botany, p.1-11, 2007.

STEINMACHER, D. A.; GUERRA, M. P.; SAARE-SURMINSKI, K.; LIEBEREI, R. A temporary immersion system improves in vitro regeneration of peach palm through secondary somatic embryogenesis. Annals of Botany, v.108, p.1463-1475, 2011.

STIPP, L. C. L.; MENDES, B. M. J.; PIEDADE, S. M. D. S.; RODRIGUEZ, A. P. M. In vitro morphogenesis of Cucumis melo var. inodorus. Plant, Cell, Tissue and Organ Culture, v.65, p.81-89, 2001.

STYER, D.J. Bioreactor technology for plant propagation. Basic Life Science, v. 32, p. 117-130, 1985.

TARMIZI, A. H.; NORJIHAN, M. A.; ZAITON, R. Multiplication of oil palm suspension cultures in a bench-top (2 litre) bioreactor. Journal of Oil Palm Research, v.16, p.4449, 2004.

TE-CHATO, S. Callus induction from cultured zygotic embryo of oil palm subsequent to plantlet regeneration. Songklanakarin Journal of Science and Technology, v. 20, p.1-6, 1998.

TE-CHATO, S.; HILAE, A.; YEEDUM, I. Improve callus induction and embryogenic callus formation from cultured young leaves of oil palm seedling. Thai Journal of Agricultural Science, v.35, p.407-413, 2002.

TEIXEIRA, J. B.; SONDAHLL, M. R.; KIRB, E. G. Somatic embryogenesis from immature zygotic embryos of oil palm. Plant Cell, Tissue and Organ Culture, v.34, p.227-233, 1993.

TEIXEIRA, J. B.; SONDAHLL, M. R. e KIRBY, E. G. Somatic embryogenesis from immature inflorescences of oil palm. Plant Cell Reports, v.13, p.247-250. 1994.

TEIXEIRA, J. B.; SONDAHL, M. R.; NAKAMURA, T.; KIRBY, E. G., Establishment of oil palm cell suspensions and plant regeneration. Plant Cell, Tissue and Organ Culture, v.40, p.105-111. 1995. 
TEIXEIRA, L.C. Potencialidades de oleaginosas para produção de biodiesel. Informe Agropecuário, Belo Horizonte, v. 26, n. 229, p. 18-27, 2005.

THAWARO, S.; TE-CHATO, S. Application of molecular markers in the hybrid verification and assessment of somaclonal variation from oil palm propagated in vitro. ScienceAsia, v.35, p.142-149, 2009.

THI, L. T.; PLESCHKA, E. Somatic embryogenesis of some Daucus species influenced by ABA. Journal of applied botany and food quality, v.79, p.1-4, 2005.

THUZAR, M.; VANAVICHIT, A.; TRAGOONRUNG, S.; JANTASURIYARAT, C. Efficient and rapid plant regeneration of oil palm zygotic embryos cV. "Tenera" through somatic embryogenesis. Acta Physiologiae Plantarum, v.33, p.123-128, 2011.

VALVERDE, R.; ARIA,S O.; THORPE, T. A. Picloran-induced somatic embryogenesis in pejibaye palm (Bactris gasipaes HBK). Plant Cell Tissue and Organ Culture, v.10, p.149-156, 1987.

VAN WINKLE, S.; JOHNSON, S.; PULLMAN, G.S. The impact of gelrite and activated carbon on the elemental composition of plant tissue culture media. Plant Cell Report, v.21, p.1175-1182, 2003.

VIEGAS, I. J. M.; MULLER, A. A. A cultura do dendezeiro na Amazônia brasileira. Belém: Embrapa-Cpatu; Manaus: Embrapa-CPAA, p.374, 2000.

WANG, L.; HUA, D.; HE, J.; DUAN, Y.; CHEN, Z.; HONG, X.; GONG, Z. Auxin Response Factor2 (ARF2) and its regulated homeodomain gene HB33 mediate abscisic acid response in Arabidopsis. PLOS Genet, DOI:1002172, 2011.

ZIMMERMAN, J. L. Somatic embryogenesis: a model for early development in higher plants. Plant Cell, Tissue and Organ Culture, v.5, p.1411-1423, 1993. 


\section{CAPÍTULO 2}

CARACTERIZAÇÃO MORFO ANATŌMICA DOS ESTÁDIOS INICIAIS DE DESENVOLVIMENTO DA EMBRIOGÊNESE SOMÁTICA DE FOLHAS IMATURAS DE PLANTAS ADULTAS DE DENDEZEIRO (Elaeis guineensis Jacq.) 


\section{RESUMO}

O objetivo do trabalho foi caracterizar morfoanatomicamente explantes foliares, calos primários e calos embriogênicos provenientes das etapas de indução e multiplicação, durante a embriogênese somática de folhas imaturas de Elaeis guineensis Jacq.. A caracterização morfo-anatômica durante os diferentes estádios (folhas aos zero dias, folhas com raiz, folhas com calo, folhas que não reagiram, calos primários, calos embriogênicos e calos embriogênicos formados a partir de calo primário) da embriogênese somática foi realizada utilizando-se o genótipo B35-17-33. Em secção transversal pôde-se verificar que as folhas utilizadas para a indução de calos apresentam epiderme unisseriada, com estômatos apenas na face abaxial da folha, a presença de hipoderme bi-estratificada, em ambas as faces, e mesofilo dorsiventral. Verificou-se que o desenvolvimento do calo estava associado ao feixe vascular, em $100 \%$ dos propágulos analisados, e que a formação de calos ocorreu principalmente nas regiões próximas aos bordos dos explantes excisados. Com a formação do calo primário foi verificado que as divisões celulares iniciam próximas aos feixes vasculares, onde se observam células de tamanho reduzido, citoplasma denso e núcleo evidente. Foi observado que calos primários são constituídos por células meristemáticas apenas em sua região mais interna, enquanto que calos embriogênicos (formados a partir de calos primários) são compostos inteiramente por este padrão celular. Aos 180 dias de cultivo em meio acrescido de ácido naftalenoacético (ANA) foram verificadas formações de raízes diretamente do explante foliar. Avaliando morfoanatomicamente folhas, após 180 dias de cultivo que não presentaram formação de calos, verificou-se epiderme unisseriada, com células epidérmicas comuns, presença de hipoderme, sem a presença de estômatos em nenhuma das faces foliares, com o mesofilo sendo constituído por parênquima do tipo homogêneo. Com a indução da calogênese a partir de folhas imaturas de dendezeiro, verificou-se que o surgimento de calos ocorre a partir de células associadas ao feixe vascular da folha. Observa-se que a maturidade do explante inicial influencia diretamente a indução de calo, uma vez que folhas com feixes vasculares pouco desenvolvidos, em sua maioria, não apresentam formação de calos. Durante a indução, observou-se a formação de dois tipos de calo: o calo primário e o calo embriogênico. A partir do calo embriogênico, verifica-se a formação de embriões somáticos, que se iniciam com o isolamento e organização de células embrionárias. 
Palavras-chave: Ontogênese, embriogênese somática, morfogênese, histologia. 


\section{ABSTRACT}

The objective of the study was describing foliar explants morpho-anatomically, primary calluses and embryogenic calluses from the induction and multiplication steps, during the Elaeis guineensis Jacq. half-grown leaves somatic embryogenesis. The morphoanatomic characterization over the different stages (leaves at zero days, rooted leaves, callused leaves, leaves that didn't react, primary calluses, embryogenic calluses and embryogenic calluses formed from the primary callus) of the somatic embryogenesis was accomplished using the B35-17-33 genotype. On cross section it was noted that the leaves used for calluses induction presented uniseriate epidermis, with stomas only on the abaxial portion of the leave, the presence of bi-stratified hypodermis, on both faces, and dorsiventral mesophile. It was verified that the callus development was associated to the vascular bundle, on $100 \%$ of the analyzed propagating material, and the callus formation occurred mainly on the regions near the excised explants. With the primary callus formation it was seen that the cell divisions started close to the vascular bundles, where reduced sized cells can be seen, dense cytoplasm and clear nucleus. It was found that the primary calluses are composed by meristematic cells only on the inner part, whereas embryogenic calluses (formed out of primary calluses) are entirely composed of this cell pattern. At 180 cultivation days in media plus the naphthalene acetic acid (NAA) it was verified roots formations directly from the foliar explant. Evaluating leaves morpho-anatomically, after 180 cultivation days that didn't present calluses formation, uniseriate epidermis were seen, with ordinary epidermal cells, hypodermis presence, not involving the presence of stomas on any foliar faces, with the mesophile being composed by uniform type parenchyma. With the calogenesis induction from half-grown leaves of African oil palm tree, it was verified that the emergence of calluses occurs from cells associated to the leaves' vascular bundle. It's observed that the early explant maturity influences directly the callus induction, once the leaves with poorly developed vascular bundles, mostly, don't present calluses formation. During the induction, it was seen the formation of two sorts of callus: the primary callus and the embryogenic callus. From the embryogenic callus, it's noted somatic embryos formation, which starts with the isolation and embryogenic cells setup.

Keywords: Ontogenesis, embryogenesis somatic, morphogenesis, histology. 


\section{INTRODUÇÃO}

Conhecido cientificamente por Elaeis guineensis (Jacq.), o dendezeiro, pertence à classe Monocotiledonae, ordem Arecales, família Arecaceae e gênero Elaeis (Mukherjee \& Sovacool, 2014; Hansen et al., 2015). É uma espécie de origem africana (Guiné-Bissau) cultivada em regiões tropicais úmidas da África, Ásia e América. No Brasil, acredita-se que o dendezeiro foi introduzido por escravos africanos, por volta de 1.700, dando origem aos dendezais subespontâneos do litoral baiano (Valois, 1997). O dendezeiro é uma das espécies mais importantes economicamente, isso por que, é a espécie que fornece a segunda maior fonte de óleo comestível no mundo (Jouannic et al., 2005).

Buscando otimizar a produção nacional, os programas de melhoramento têm sido estrategicamente implementados por instituições de pesquisa, com ênfase na introdução, seleção e melhoramento genético de materiais com características agronômicas de interesse. No entanto, sendo uma espécie monocotiledônea, o dendezeiro apresenta um único ápice crescente, sem perfilhamento, o que impede sua multiplicação vegetativa por métodos convencionais, tornando praticamente impossível obter culturas uniformes e perpetuar as características de uma planta com alto valor genético selecionado. Portanto, avanços são essenciais para alcançar protocolos seguros e confiáveis para a propagação clonal de materiais superiores, seja para produção em larga escala de mudas ou para reduzir os ciclos de seleção e otimizar os programas de melhoramento genético (Scherwinski-Pereira et al 2010; Jaligot et al 2011; Ooi et al 2012; Silva et al., 2012).

Das diferentes técnicas de clonagem in vitro, a embriogênese somática é, sem dúvida, a mais comumente recomendada para a propagação clonal de palmeiras (Schwendiman et al., 1988; Karun et al., 2004; Scherwinski-Pereira et al., 2010; Jaligot et al., 2011). Esta técnica permite que plantas possam ser regeneradas a partir de células somáticas que, por meio de uma série ordenada de fases embriogênicas, originam estruturas bipolares (embriões somáticos) capazes de originar plantas completas (Reinert, 1958; Williams \& Maheswaran, 1986; Soh et al., 2011).

Durante o processo de propagação clonal, os embriões somáticos formados apresentam características anatômicas semelhantes a embriões zigóticos. Ambos são caracterizados pela diferenciação do ápice e da raiz, passando geralmente, pelas seguintes etapas de desenvolvimento embrionário: globular, cordiforme, torpedo e 
cotiledonar. No entanto, apesar da existência de um grande número de trabalhos na literatura, a embriogênese somática ainda está longe de ser completamente dominada e compreendida, embora se saiba que, em geral, a indução de calos e o uso de auxinas são pré-requisitos fundamentais para a obtenção de resultados satisfatórios (Verdeil et al., 2001; Corredoira et al., 2006; Karami \& Saidi 2010).

O uso de análises histológicas durante a embriogênese somática provou ser uma ferramenta útil para a compreensão do processo embriogênico. $O$ estudo do desenvolvimento de células e tecidos nas diferentes etapas do processo possibilita a melhoria de diversos protocolos de propagação clonal, permitindo o entendimento do funcionamento de todo o desenvolvimento ontogênico (Verdeil et al., 2001; Sané et al., 2006;. Santos et al., 2006).

Por meio de estudos morfoanatômicos também é possível identificar as fases do desenvolvimento embrionário (Schwendiman et al., 1990; Silva et al., 2014; Moyo et al., 2015). Dessa forma, o conhecimento mais profundo dos eventos morfoanatômicos envolvidos no processo embriogênico pode melhorar significativamente a compreensão das diferentes etapas envolvidas na embriogênese somática, bem como ajudar a assegurar que certas condições de cutivo, tais como a composição do meio de cultura, podem ser melhor ajustadas. Além disso, não é difícil imaginar que a caracterização morfoanatômica exata das diferentes fases da embriogênese somática em uma espécie pode constituir um marcador morfológico do processo (Batagin-Piotto et al., 2012; Balzon et al., 2013).

Neste contexto, o objetivo deste trabalho foi avaliar os eventos morfoanatômicos envolvidos da embriogênese somática a partir de folhas imaturas de dendezeiro (Elaes guineensis Jacq.). 


\section{MATERIAL E MÉTODOS}

\subsection{Local de realização do experimento}

O experimento foi conduzido no Laboratório de Cultura de Tecidos Vegetais (LCT-II) da Embrapa Recursos Genéticos e Biotecnologia, situado em Brasília - DF, Brasil.

\subsection{Obtenção do material vegetal}

Para a indução da embriogênese somática foram utilizadas como material vegetal, folhas imaturas e ainda não expandidas (palmito), oriundas de plantas adultas de dendezeiros variedade da B35-1733, fornecidas pelo Programa de Melhoramento Genético da Embrapa Amazônia Ocidental, a partir do Banco de Germoplasma da espécie localizado no Rio Preto da Eva - AM, Brasil.

Após coletado em campo, o material vegetal foi conduzido ao laboratório, onde as folhas mais externas foram removidas e o tamanho do palmito reduzido para aproximadamente $30 \mathrm{~cm}$ de comprimento da região basal meristemática (próxima ao meristema) até o ápice foliar do cilindro central (região mais afastada do meristema).

A indução da embriogênese somática foi realizada a partir da inoculação de segmentos foliares em placas de Petri $(15 \times 90 \mathrm{~mm})$ contendo meio de cultura composto pela constituição salina e vitaminas de MS (Murashige \& Skoog, 1962), suplementado com 0,5 g. $\mathrm{L}^{-1}$ de caseína hidrolisada, 0,5 g. $\mathrm{L}^{-1}$ de glutamina, 2,5 g. $\mathrm{L}^{-1}$ de carvão ativado, $30 \mathrm{~g} \cdot \mathrm{L}^{-1}$ de sacarose, 2,5 g. $\mathrm{L}^{-1}$ de Phytagel e $225 \mu \mathrm{m}$ de Picloram. $\mathrm{O} \mathrm{pH}$ dos meios foi ajustado para $5,7 \pm 0,1$ sendo autoclavados à temperatura de $121^{\circ} \mathrm{C}$ e pressão de 1,3 atm por 20 minutos.

Foram inoculados seis segmentos de folhas jovens de aproximadamente $1 \mathrm{~cm}^{2}$, provenientes das regiões apical e basal dos palmitos, com a face adaxial em contato com o meio de cultura, em placas de Petri contendo $25 \mathrm{~mL}$ de meio nutritivo. Todos os experimentos foram mantidos em sala de crescimento sob temperatura de $25 \pm 2 \stackrel{\circ}{\circ} \mathrm{C}$ acondicionados no escuro. 
Nestas condições de cultivo, os explantes foram mantidos por 3 subcultivos de 60 dias cada para a obtenção de calos primários e mais um subcultivo de 90 dias para a obtenção de calos embriogênicos.

\subsection{Estudos morfoanatômicos dos estágios de desenvolvimento}

A caracterização morfoanatômica dos diferentes estádios (folhas aos zero dias, folhas com raiz, folhas com calo, folhas que não reagiram, calos primários, calos embriogênicos e calos embriogênicos formado a partir de calos primários) da embriogênese somática do dendezeiro foi realizada utilizando-se o genótipo B35-17-33. Para tanto, cinco amostras de cada estádio de desenvolvimento foram coletadas e fixadas em FAA 50 (formaldeído 37-40\%, ácido acético glacial e álcool etílico 50\%, nas proporções 1:1:18, v/v sob vácuo (Johansen, 1940), lavadas duas vezes e estocadas em etanol $50 \%$. Em seguida, as amostras foram desidratadas em série etílica crescente (30 a 100\%) e infiltradas em historresina (Leica®). Secções com até $10 \mu \mathrm{m}$ de espessura foram obtidas em micrótomo rotativo manual Leica $\AA$, distendidas sobre água em uma lâmina de vidro, sobre placa aquecedora a $40{ }^{\circ} \mathrm{C}$. Os cortes foram corados com azul de toluidina a $0,5 \%$ e analisados sob microscópio óptico. O registro das lâminas de cada estádio foi realizado em fotomicroscópio com sistema de captura de imagens (Leica® DM750). 


\section{RESULTADOS E DISCUSSÃO}

\subsection{Estudos morfoanatômicos dos estádios de desenvolvimento}

A Figura 1 caracteriza morfoanatômicamente as folhas imaturas de Elaeis guineensis utilizada como explante inicial na indução da embriogênese somática. Morfologicamente, a folha imatura de dendezeiro apresenta superfície lisa, textura maleável, ausência de clorofila e, como característica marcante do grupo em que está inserida (Liliopsida), apresenta nervuras paralelas (Figura 1 A).

$\mathrm{Na}$ Figura $1 \mathrm{~B}$, pode ser verificada a secção transversal da nervura mediana que é proeminente nas duas faces, sendo que a saliência adaxial possui cerca de três vezes a largura da saliência abaxial. A vascularização é composta por um grande cilindro central e 4-5 traços vasculares isolados voltados para a face adaxial, caracterizando feixes vasculares pouco desenvolvidos. Contornando essa região vascularizada, foi observada uma camada de tecido esclerenquimático. Luis et al. (2010) verificaram, na nervura central de dendezeiro, a presença de um feixe vascular maior associado a outros feixes menores.

Em secção transversal, pôde-se verificar a presença de estômatos apenas na face abaxial da folha, com estômatos nivelados com as demais células da epiderme e câmara subestomática ampla (Figura $1 \mathrm{D}$ ). No entanto, diversos autores classificam as folhas de dendezeiro como sendo anfiestomáticas e descrevem a presença de estômatos nas faces abaxial e adaxial com maior concentração na face abaxial (Luis et al., 2010, Habib et al., 2012). Essa diferença encontrada na presença de estômatos apenas em uma face foliar pode estar associada à maturidade do explante analisado, uma vez que, no presente trabalho foram analisadas folhas imaturas, contrariamente aos demais trabalhos que avaliaram folhas já desenvolvidas e clorofiladas. A quantidade, a distribuição, o tamanho e a forma dos estômatos são características típicas de cada espécie, e podem mudar em virtude da maturidade do tecido foliar, bem como, devido à adaptação às condições ambientais em que a planta é submetida (Muchow \& Sinclair, 1989; Pearce et al., 2005).

Em ambas as faces da folha, abaixo da camada epidérmica foi observada a presença de hipoderme biestratificada, consistindo de duas camadas de células com tamanho superior ao das células epidérmicas (Figura 1 D). Esse resultado corrobora o de Luis et al. (2010) que também verificaram a presença de hipoderme em ambas as superfícies foliares de dendezeiro, com maior espessamento na face adaxial. Stauffer 
et al. (2003) também verificaram a presença de hipoderme na folha de Asterogyne martiana, uma palmeira de ampla ocorrência na América Central. No entanto, nessa espécie, a hipoderme foi observada apenas na face abaxial. Segundo Tomlinson (1990), a hipoderme é mais desenvolvida em palmeiras que evoluíram em ambientes áridos, sendo geralmente ausente em plantas nativas de ambientes sombreados, podendo a presença dessa camada celular, estar associada à proteção contra a desidratação.

O mesofilo da folha imatura de dendezeiro é dorsiventral, constituído por 2-3 camadas de parênquima paliçádico imediatamente abaixo da hipoderme da face adaxial (Figura 1 D). Semelhante ao descrito por Appezzato-da-Glória (2004), as células do parênquima paliçádico são tipicamente alongadas, com formato de barras dispostas em fileiras, que, ao longo do mesofilo, podem ser iguais em comprimento ou, como verificado no presente trabalho, se tornarem menores à medida que se aproximam da região central do mesofilo. Já o parênquima lacunoso apresenta 2 a 3 camadas de células mais arredondadas e alguns espaços intercelulares (Figura 1 D). 

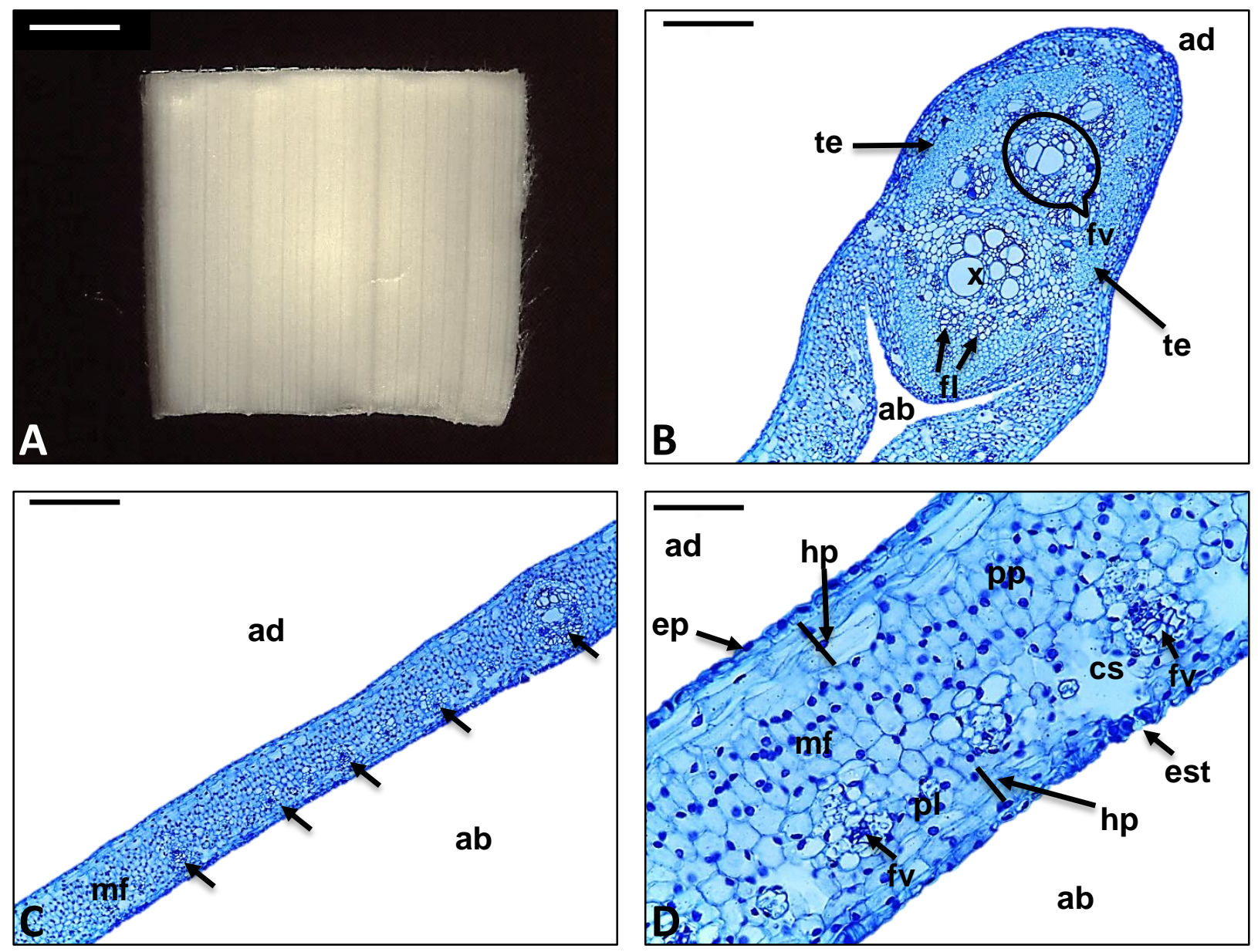

Figura 1. Caracterização morfoanatômica de folhas imaturas originadas de plantas adultas de dendezeiro (Elaeis guineensis Jacq.) utilizada como explante inicial na indução da embriogênese somática. A. Aspecto externo de segmentos de folha imatura de Elaeis guineensis; B. Secção transversal da nervura mediana: notar sistema vascular nítido, com tecido esclerenquimático contornando a região vascular; $C$ e $D$. Secções transversais da ala foliar. C. Setas indicando feixes vasculares. Abreviações: $\mathrm{ab}=$ abaxial; $\mathrm{ad}$ = adaxial; $\mathrm{cs}$ = câmara subestomática; $\mathrm{ep}$ = epiderme; est = estômato; $\mathrm{fv}=$ feixe vascular; $\mathrm{fl}=$ floema $; \mathrm{hp}=$ hipoderme; $\mathrm{mf}=$ mesofilo; $\mathrm{pl}=$ parênquima lacunoso; $\mathrm{pp}=$ parênquima paliçádico; te = tecido esclerenquimático; $\mathrm{x}=$ xilema . Barras: A. $2 \mathrm{~mm}$; B-C. 0,2 mm; D. 0,05 mm.

A formação inicial de calos primários foi observada por volta dos 60 dias de cultivo, embora as avaliações das taxas de formação de calos tenham sido realizadas apenas aos 180 dias. Verificou-se que o desenvolvimento dos calos estava associado aos feixes vasculares em $100 \%$ dos propágulos analisados e que a formação de calo ocorreu principalmente nas regiões próximas a região excisada do explante, onde 
existe maior contato entre as células da região vascular com os componentes do meio nutritivo (Figura $2 \mathrm{~A}-\mathrm{F}$ ).

Morfologicamente, o início da formação de calo é caracterizado pelo rompimento da epiderme e o surgimento de aglomerados celulares de coloração bege-amarronzada com formato, inicialmente, arredondado, tendendo para um formato mais alongado com o desenvolvimento do calo (Figura 2 A). Semelhante ao presente trabalho, Sané et al. (2006) também verificaram a formação de calos em Phoenix dactylifera após 2 meses de cultivo. Anatomicamente, foi verificado que, a formação de calor ocorre no mesofilo da folha com feixes vasculares mais desenvolvidos quando comparado àqueles encontrados nas folhas que não apresentaram formação de calo (Figura 2 B).

Ao longo do desenvolvimento dos calos, as células do parênquima paliçádico adjacente apresentam aumento na largura e diminuição na altura, evidenciando o achatamento devido à compressão das mesmas contra a epiderme. Já o parênquima lacunoso, contíguo ao calo aparece com rompimento celular e é nessa região em que a epiderme se rompe à medida em que os calos vão se desenvolvendo (Figura 2 C e D).

As divisões celulares começam próximo ao feixe vascular, onde se observam células de tamanho reduzido, citoplasma denso e núcleo evidente (Figura 2 C). A proliferação celular resulta no aumento da espessura da folha (Figura 2 C e D), onde há inicialmente um predomínio de divisões periclinais, resultando em células enfileiradas. As células de menor tamanho (cerca de $6 \mu \mathrm{m}$ de diâmetro) se mantêm no centro inicial do calo, caracterizando uma região promeristemática, região que permanece no centro ao longo do desenvolvimento do mesmo. As células do calo desenvolvido apresentam tamanho maior (cerca de $28 \mu \mathrm{m}$ de diâmetro) quando mais afastadas da região promeristemática que, de acordo com as análises realizadas, está sempre associada à região do procâmbio (Figura 2 C-F). 

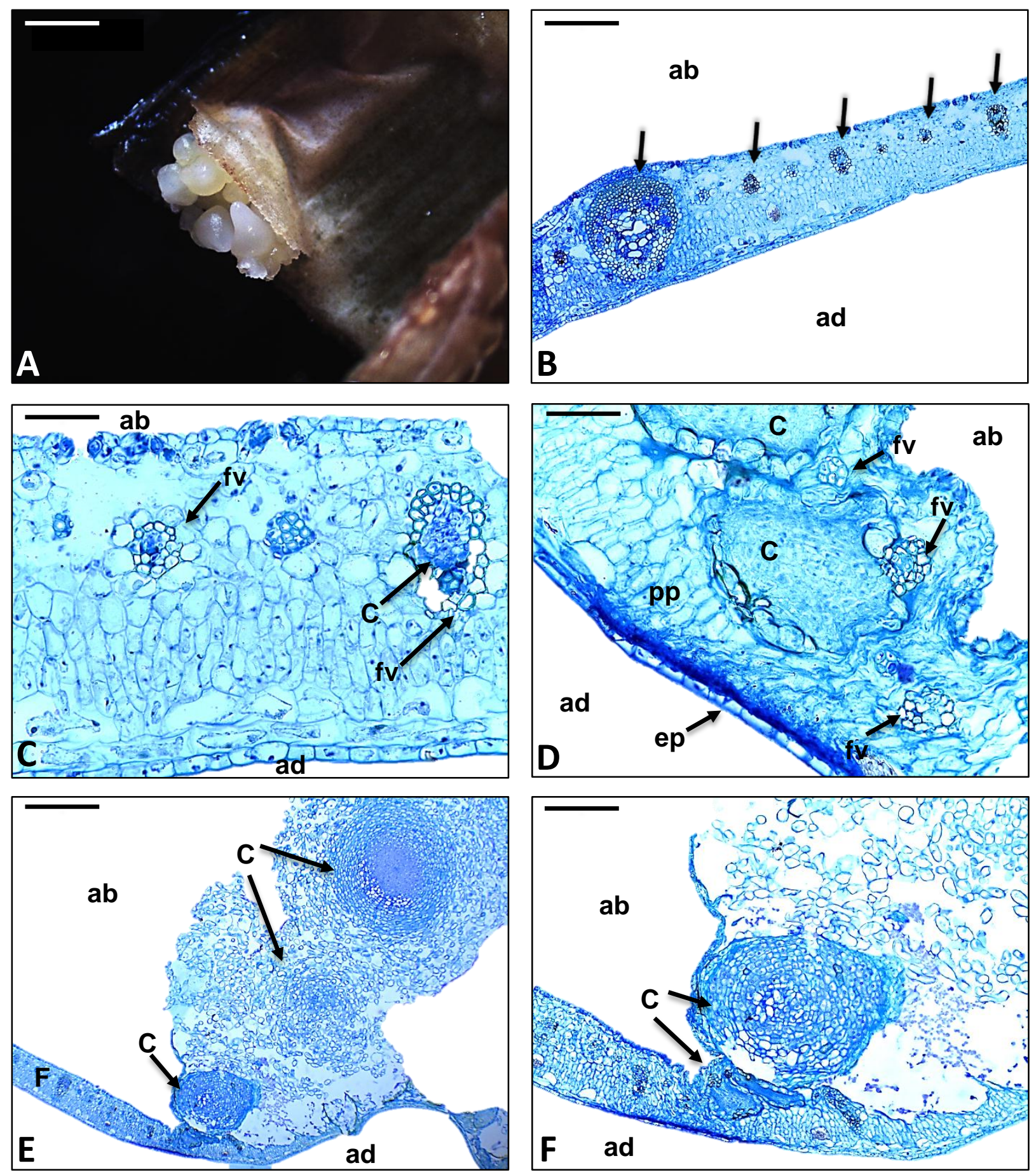

Figura 2. Segmento foliar imaturo de dendezeiro (Elaeis guineensis Jacq.) originário de plantas adultas com formação de calo primário após 60 dias de cultivo em meio de indução, contendo $225 \mu \mathrm{m}$ de Picloram. Aspecto morfológico da formação de calos. A. Morfologia externa. B-F. Secção transversal da folha com calo. B. Setas indicando

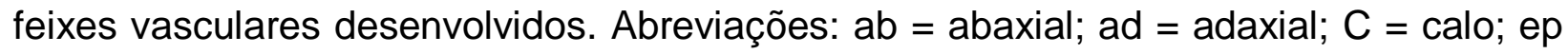
= epiderme; fv = feixe vascular; $F$ = folha; $p p=$ parênquima paliçádico. Barras: $A$. 2 mm; B-F. 0,2 mm; C-D. 0,05 mm; E. 0,5 mm. 
A identificação do início da formação do calo pode ser uma informação importante para a otimização do protocolo de obtenção de embriões somáticos. Dessa forma, diversos autores avaliam e descrevem a origem de formação de calos em diversas espécies. Em dendezeiro, células do procâmbio de explantes foliares foram apontadas como a origem da proliferação de calos primários por Schwendiman et al. (1988). Segundo Jones (1983), a multiplicação de células perivasculares ocorre levando à formação de centros com alta atividade meristemática, a partir do qual se origina o calo. Em secção transversal de folhas imaturas de dendezeiro, Duval et al. (1995) observaram que o calo se origina a partir da multiplicação de células perivasculares, resultando numa camada de tecido meristemático, com quatro ou cinco células de espessura, perto do xilema.

A proliferação de calos próximo aos tecidos vasculares também tem sido observada em explantes de folhas de outras espécies da família Arecaceae, tais como Phoenix dactylifera (Sané et al., 2006), Cocos nucifera (Buffard-Morel et al., 1992), Bactris gasipaes (Steinmacher et al., 2011) e Acrocomia aculeata (Moura, 2009), mas também em espécies de outras famílias botânicas, como o Gossypium hirsutum (Gawel et al., 1986), Acacia raddiana (Sané et al., 2000), Coffea arabica (Michaux-Ferriere et al., 1987; Bieysse et al., 1993) e Coffea canephora (Michaux-Ferriere et al., 1989).

O procâmbio é um tecido meristemático responsável pela formação de tecidos vasculares. Acredita-se que a formação de calo esteja intimamente relacionada a este tecido, uma vez que essa região apresenta células com maior potencial mitótico. 0 procâmbio também está próximo ao floema, que carrega em seu interior fitorreguladores. Dessa forma, estes fitorreguladores promoveriam mais facilmente uma resposta das células procambiais aos estímulos gerados pelos componentes do meio nutritivo (Appezzato-da-Glória, 2004).

Segundo Rose et al. (2006), as células do procâmbio que durante o desenvolvimento da planta naturalmente se diferenciariam para a formação da nervura da folha, após serem estimuladas pela auxina presente no meio nutritivo, entram na rota de desdiferenciação e reprogramação celular, ocasionando a proliferação dessas células e formação de calos.

Diante disso, Barbier-Brygoo et al. (1989) mostraram que a multiplicação de células que ocorre durante a formação do calo começa com a hiperpolarização de polipeptídios da membrana sob a ação da auxina. De acordo com Goldsworthy \& 
Rathore (1985), esta hiperpolarização é uma consequência da desestabilização da polaridade dos campos elétricos celulares que podem estar associados ao crescimento celular desorganizado observado na presença de 2,4-D, durante o desenvolvimento do calo.

A Figura 3, caracteriza aspectos morfoanatômicos de folhas imaturas de dendezeiro, após 180 dias de cultivo em meio de indução, porém, sem o surgimento de calos. Morfologicamente a folha imatura apresenta superfície lisa, textura mais rígida e coloração mais amarelada quando comparada ao explante inicial (Figura 3 A).

$\mathrm{Na}$ secção transversal da folha, pode-se verificar uma epiderme unisseriada, com células epidérmicas normais e, abaixo dessa camada, é observada a presença de hipoderme (Figura $3 \mathrm{C}$ e D). Nos explantes avaliados, não foi verificada a presença de estômatos em nenhuma das faces foliares. Isso pode estar associado à imaturidade do explante, uma vez que se trata de um tecido retirado da região do palmito mais próxima do meristema apical da planta, a região basal, que por esse motivo é a região mais jovem e menos desenvolvida.

O mesofilo é constituído por parênquima do tipo homogêneo com cerca de 6-8 camadas de células arredondadas com poucos espaços intercelulares (Figura $3 \mathrm{C}$ e D). De acordo com Akin \& Robinson (1982), a presença de um parênquima compacto (com espaços intercelulares reduzidos ou ausentes) interfere na distribuição de carbono no mesofilo, o que implica uma menor eficiência fotossintética. No presente trabalho, por se tratar de uma folha imatura e aclorofilada, a redução da distribuição de carbono não teria grande impacto, uma vez que a folha analisada ainda não realiza fotossíntese (Figura $3 \mathrm{C}$ e D). 

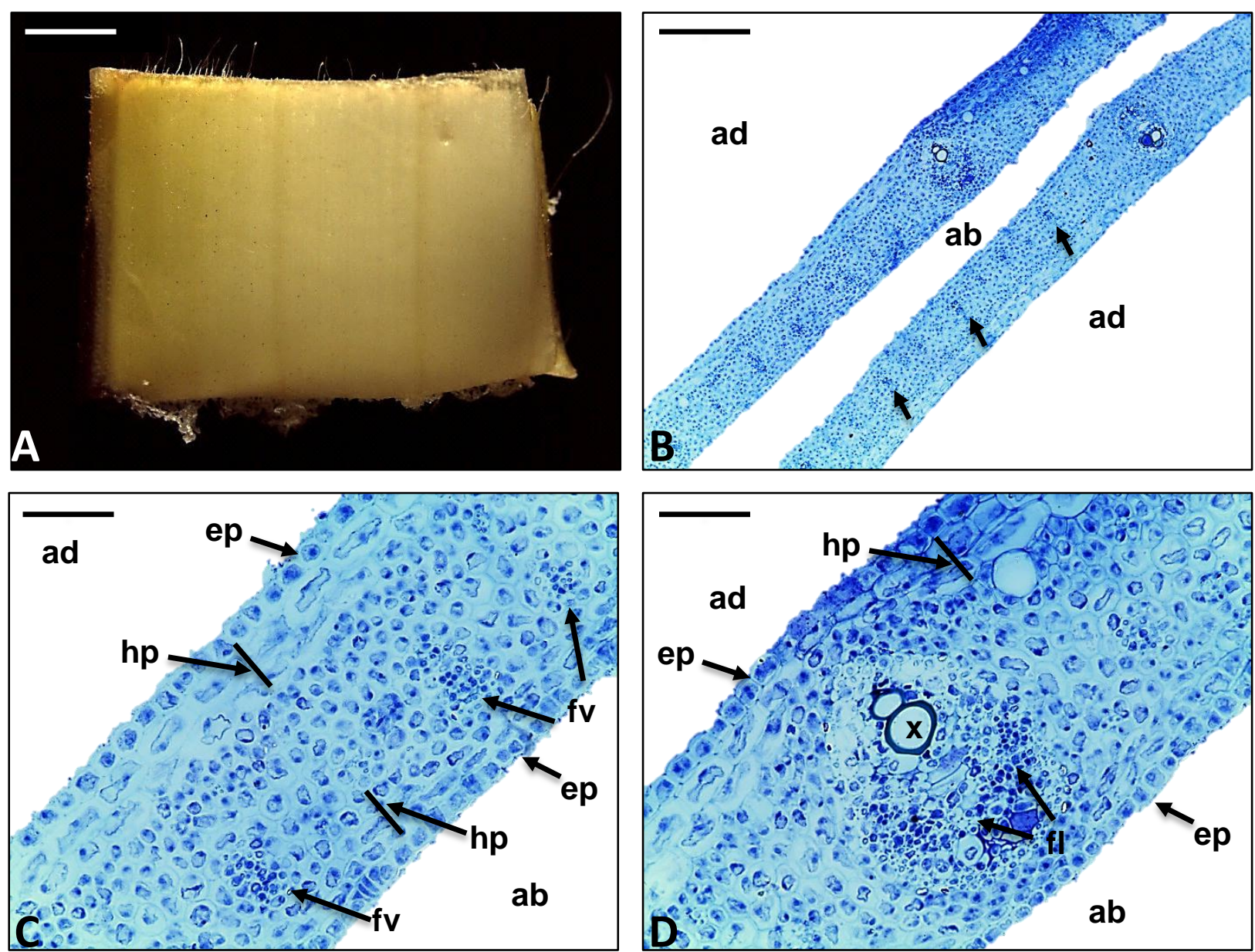

Figura 3. Segmento foliar imaturo de dendezeiro (Elaeis guineensis Jacq.) originário de plantas adultas que não reagiu à indução de calo primário, após 180 dias de cultivo em meio contendo $225 \mu \mathrm{M}$ de Picloram. A. Morfologia externa. B-D. Secção transversal da folha sem a formação de calo. B. Ocorrência feixes vasculares pouco desenvolvidos (setas). Abreviações: $\mathrm{ab}=$ abaxial; $\mathrm{ad}=$ adaxial; $\mathrm{ep}=$ epiderme; $\mathrm{fv}=$ feixe vascular; $\mathrm{fl}=$ floema; hp = hipoderme; $x=$ xilema. Barras: A. $2 \mathrm{~mm}$; B. 0,2 mm; C-D. 0,5 mm.

Segundo Gueye (2009), fatores como o tamanho, a idade e a maneira em que um explante é cultivado podem afetar o êxito da indução da morfogênese no cultivo in vitro. Dessa forma, diferenças significativas na resposta embriogênica foram observadas entre tecidos vegetativos mais e menos desenvolvidos (Williams \& Maheswaran, 1986). A resposta relativa de vários tecidos imaturos parece ser característica da espécie, pois hipocótilos de Gossypium spp. produziram mais embriões somáticos do que sementes ou cotilédones (Trolinder \& Xhixian, 1989), enquanto que os cotilédones apresentaram melhor resposta embriogênica do que hipocótilos em Cucumis sativus L. (Stipp et al., 2001). De forma geral, os tecidos 
vegetativos maduros são mais convenientes e mais facilmente disponíveis do que os tecidos imaturos ou florais (Elmeer, 2013). No entanto, determinados tecidos, quando muito desenvolvidos não apresentam resposta embriogênica satisfatória em algumas espécies, sendo necessário verificar o tipo e a maturidade do explante para cada cultura.

A Figura 4 caracteriza aspectos morfoanatômicos das folhas imaturas de Elaeis guineensis com formação de raiz aos 180 dias de cultivo, em meio acrescido de ácido naftalenoacético (ANA). Morfologicamente, a folha imatura de dendezeiro apresenta textura rígida e coloração amarronzada devido à presença de oxidação. Nessa etapa, foi verificado o surgimento de estruturas semelhantes a raízes, cujo tipo de estrutura foi confirmado com a realização das secções anatômicas (Figura 4 A-D). 

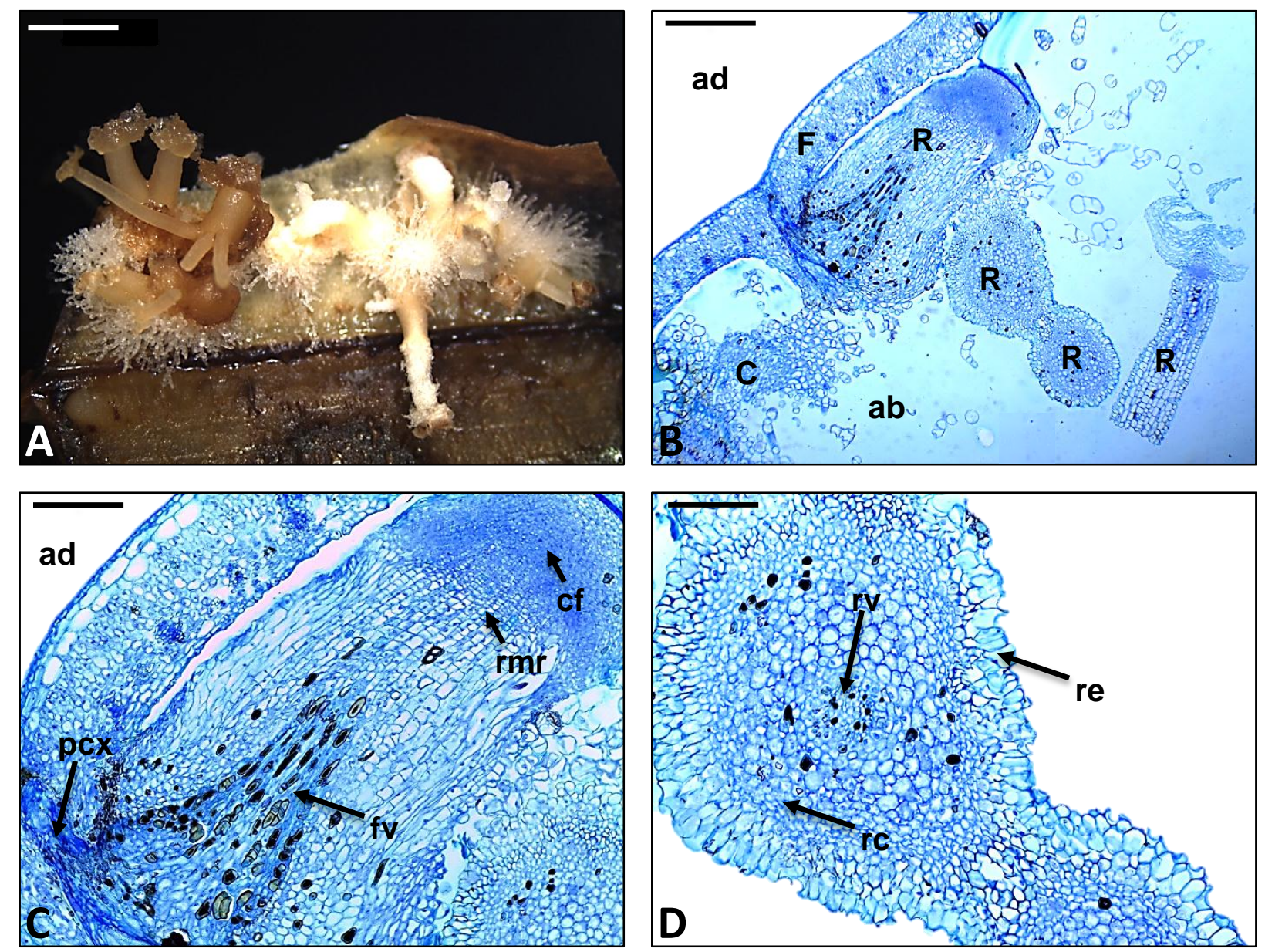

Figura 4. Segmento foliar imaturo de dendezeiro (Elaeis guineensis Jacq.) originário de plantas adultas com formação de raiz em meio de cultura suplementado com ácido naftalenoacético (ANA) após 180 dias de cultivo. A. Morfologia externa. B-D. Secção transversal da folha e longitudinal e transversal da raiz. Abreviações: $a b=$ abaxial; $a d=$ adaxial; $\mathrm{C}=$ calo; $\mathrm{cf}=$ coifa; $\mathrm{F}=$ folha; $\mathrm{pcx}=$ ponto de conexão; $\mathrm{R}=$ raiz; $\mathrm{rc}$ = região cortical; re = região epidérmica; $r m r$ = região meristemática da raiz; $r v$ = região vascular. Barras: A. 2 mm; B. 0,5 mm; C-D. 0,2 mm.

Semelhante ao presente trabalho, diversos autores verificaram a formação de raízes durante a etapa de indução da embriogênese somática. Loiseau et al. (1995) com Pisum sativum, Matsuoka \& Hinata (1979) com Solanum melongena., Gueye et al. (2009) e Sané et al. (2012), com Phoenix dactylifera também ressaltaram a formação de raízes nessa etapa do cultivo in vitro. A presença de raízes nos explantes foliares de dendezeiro não foi algo esperado. Diante disso, a realização das análises anatômicas possibilitou a verificação de que as estruturas que estavam sendo formadas eram raízes adventícias. 
Anatomicamente foi observado um ponto de conexão da raiz ligando-a diretamente ao explante foliar, o que caracteriza a organogênese direta (Figura $4 \mathrm{~B} \mathrm{e}$ C). No entanto, próximo a essa região, também foi identificada a formação de aglomerados celulares, evidenciando a presença de calo (Figura $4 \mathrm{~B}$ e C). Almeida et al. (2012), analisando a influência de diferentes reguladores de crescimento (ANA associado com BAP) na indução de rotas embriogênicas ou organogênicas de Bactris gasipaes verificaram a presença de centros meristemáticos que, a partir do contato com esses reguladores, formaram regiões com células procambiais que deram início à rota organogênica.

Através da secção longitudinal da raiz, foi verificada a presença de tecidos vasculares visíveis, a região meristemática apical da raiz onde há inicialmente um predomínio de divisões periclinais, resultando em células achatadas e enfileiradas e a região da coifa da raiz claramente distinta das demais regiões, pela presença de células com coloração mais escura (Figura $4 \mathrm{C}$ ). Resultados semelhantes foram encontrados por Habib et al. (2012), que analisando raízes de clones de dendezeiro verificaram a presença de quatro regiões distintas na raiz: 1 = região vascular procambial, 2 = região meristemática denominada centro quiescente, $3=$ região caliptrogênica ou região de células vivas da coifa e 4 = coifa.

Em seção transversal das raízes formadas foi observada a presença de uma região de revestimento denominada região epidérmica, composta por células alongadas e enfileiradas contornando todo o corte da raiz. Internamente a essa camada foram verificadas de 4 a 9 camadas de células menores com formato mais arredondado que compõem a região cortical (Figura $4 \mathrm{D}$ ). E internamente, verifica-se a presença de uma região vascular composta de células meristemáticas (Figura $4 \mathrm{D}$ ). Os resultados aqui obtidos corroboram os de El-Bahr et al. (2004) que observaram um formato arredondado nos cortes transversais de raízes de Phoenix dactylifera provenientes do cultivo in vitro. Semelhante ao presente trabalho, esses autores descrevem a presença de regiões epidérmicas, corticais e vasculares.

Após 180 dias de cultivo, a formação de calos primários que surgiram a partir do mesofilo das folhas imaturas de dendezeiro foi identificada. O calo primário é compacto, com formato alongado, de cor bege amarronzada, com crescimento regular e consistência ligeiramente aquosa (Figura $5 \mathrm{~A}$ ). Com a ruptura do mesofilo, é verificada a formação de diversos calos primários com formato alongado e crescimento relativamente lento. 
Segundo Pádua et al. (2013), as características morfológicas de calos, tais como coloração, textura e consistência podem ser genótipo-específico e, dessa forma, tornase necessária a análise anatômica desses propágulos a fim de verificar o tipo de resposta obtida pela indução embriogênica.

Nos cortes histológicos foram observadas três regiões distintas que compõem o calo primário (Figura 5 B-D). Mais externamente foi verificada uma região periférica composta por células relativamente grandes, apresentando formatos variados, com 122 a $165 \mu \mathrm{m}$ de diâmetro, amplos espaços intercelulares, 1,7 $\mu \mathrm{m}$ de espessura nas paredes de duas células contíguas e vacúolos bem desenvolvidos. Internamente foi observada a presença de uma região de células parenquimáticas com núcleo bem delimitado, citoplasma denso, apresentando cerca de 38 a $46 \mu \mathrm{m}$ de diâmetro, algumas das quais estavam em divisão celular. Nessa região, os espaços intercelulares são reduzidos e a parede celular é mais espessa do que nas células da região periférica, tendo cerca de 3,2 $\mu \mathrm{m}$ de espessura nas paredes de duas células contíguas (Figura 5 $B-D)$.

Já na região mais interna foi observada a zona meristemática do calo com células pequenas, com 17 a $24 \mu \mathrm{m}$ de diâmetro, isodiamétricas, com citoplasma denso, paredes celulares mais estreitas, com aproximadamente $0,7 \mu \mathrm{m}$ e núcleo proeminente. Várias células apresentaram dois núcleos em um mesmo citoplasma, evidenciando a citocinese ainda não concluída no processo de divisão celular (Figura 5 B-D). 

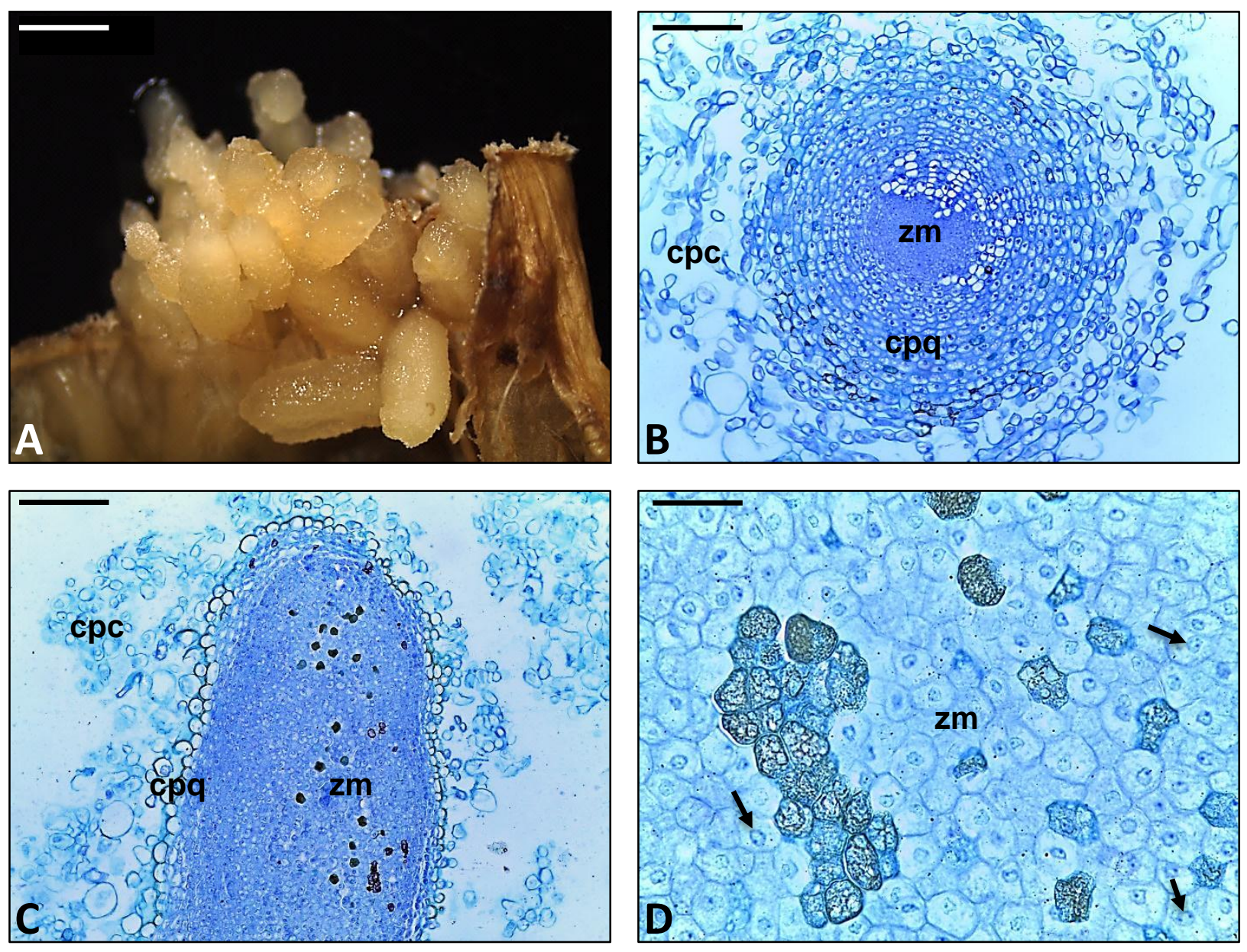

Figura 5. Aspectos morfológicos e anatômicos do calo primário de dendezeiro (Elaeis guineensis Jacq.) obtido de folhas imaturas de plantas adultas aos 180 dias de cultivo em meio de cultivo contendo $225 \mu \mathrm{M}$ de Picloram. A. Morfologia externa. B-D. Secção do calo primário. Setas indicam divisão celular evidenciada pela duplicidade de núcleos nas células. Abreviações: $\mathrm{cpq}=$ células parenquimáticas; $\mathrm{cpc}=$ células periféricas do calo; zm = zona meristemática. Barras: A. $2 \mathrm{~mm}$; B-C. 0,2 mm; D. 0,05 mm.

Calos primários com aspectos anatômicos semelhantes aos obtidos nesse trabalho são relatados em diversas espécies de palmeiras. Em indução, a partir de tecidos do tipo TCL (thin cell layer) a partir de plântulas de Bactris gasipaes, Steinmacher et al. (2007) também observaram a presença de uma região meristemática composta por células isodiamétricas, com citoplasma denso e núcleo evidente. A análise histológica do calo primário compacto de Phoenix dactylifera mostrou que eles eram constituídos por pequenas células meristemáticas com citoplasma denso, ricas em proteína solúvel. Os calos globulares compactos obtidos por esses autores foram caracterizados por apresentar um crescimento muito lento. 
Além disso, começaram a degenerar e necrosar muito rapidamente (Sané et al., 2006). Em indução de calo a partir de embriões zigóticos de Acrocomia aculeata (Jacq.) Lodd. ex Martius) e Euterpe oleracea, Moura et al. (2008) e Scherwinski-Pereira et al. (2010), respectivamente, também verificaram a presença de uma região meristemática.

Diferentemente do presente trabalho, Verdeil et al. (2001) verificaram que a zona meristemática do calo primário de Cocos nucifera encontra-se na região periférica, enquanto nas regiões mais internas foram observadas células parenquimáticas vacuoladas.

Analisando massas celulares induzidas a partir de folhas imaturas de dendezeiro, Pádua et al. (2013) também verificaram diferentes tipos celulares, dentre eles, células vacuoladas grandes, células parenquimáticas e células meristemáticas. Os resultados aqui obtidos corroboram os de Scherwinski-Pereira et al. (2010) que verificaram a presença de três regiões que compõem os calos primários de dendezeiro obtidos a partir da técnica de TCL (thin cell layer). Esses autores evidenciaram uma região de revestimento do calo, além da presença de células parenquimáticas e uma região mais interna, com características meristemáticas.

$\mathrm{Na}$ análise histológica de calos obtidos da embriogênese somática de dendezeiro a partir de embriões zigóticos, Balzon et al. (2013) também evidenciaram a zona meristemática na parte mais interna do calo primário, constituída por células isodiamétricas com citoplasma denso e núcleo proeminente. Silva et al. (2012) observaram a presença de células meristemáticas em calos primários obtidos a partir de embriões zigóticos de Elaeis guineensis. Ainda em dendezeiro, Schwendiman et al. (1988) relatam que o crescimento do calo primário continua de uma forma regular ao longo das subculturas.

Após 180 dias de cultivo, verificou-se o surgimento de calos embriogênicos formados a partir de células do calo primário. De forma geral, o calo primário apresenta formato alongado e coloração bege amarronzada, enquanto que o calo embriogênico, em seu estado inicial, apresenta coloração amarelada, aspecto menos aquoso e formato irregular (Figura $6 \mathrm{~A}$ ).

Anatomicamente, foi verificada a presença de células periféricas e vacuoladas do calo primário contornando parte da região do calo embriogênico que é composto por células tipicamente meristemáticas, com citoplasma denso, núcleo proeminente e intensa atividade celular (Figura 6 B-D). Acredita-se que o calo embriogênico teve origem a partir de células da zona meristemática do calo primário, por se tratar de 
células mais desdiferenciadas e semelhantes às células encontradas no calo embriogênico. Segundo Duval et al. (1995), o surgimento do calo embriogênico granular típico é raramente verificado em dendezeiro. No entanto, quando esse evento acontece, é observado que esse tipo de calo surge na superfície do calo primário cultivado em altas concentrações de auxina. Em contraste com a formação do calo primário que possui origem a partir de células internas do explante induzido, o calo embriogênico está localizado na periferia do calo primário ao qual eles estão apenas ligeiramente ligados (Touchet et al., 1991).
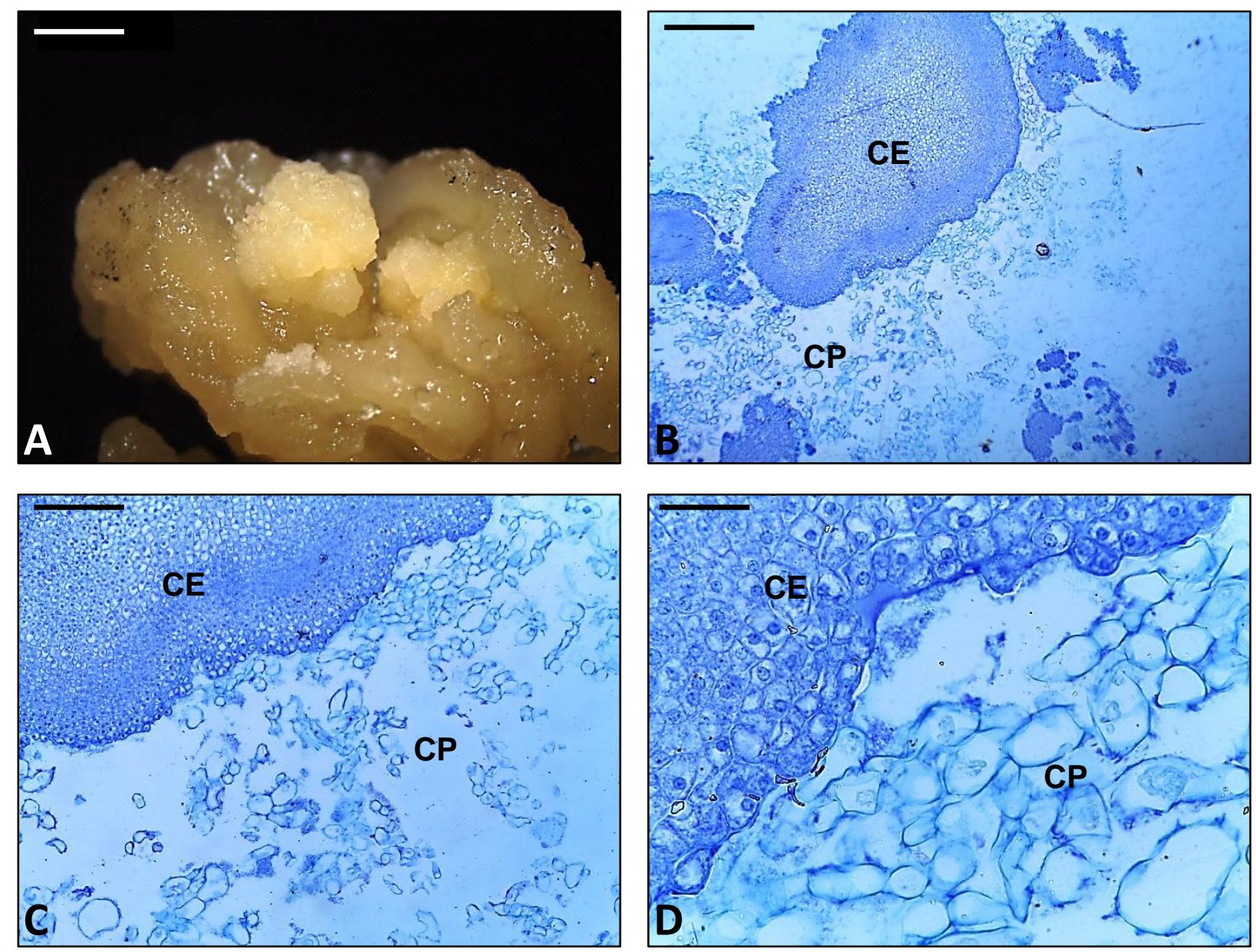

Figura 6. Aspectos morfológicos e anatômicos do calo embriogênico formado a partir de células do calo primário de dendezeiro (Elaeis guineensis Jacq.), após 180 dias de cultivo em meio contendo $225 \mu \mathrm{M}$ de Picloram. A. Morfologia externa. B-D. Secção do calo embriogênico e do calo primário. Abreviações: $\mathrm{CE}=$ calo embriogênico; $\mathrm{CP}=$ calo primário. Barras: A. $2 \mathrm{~mm}$; B. 0,5 mm; C. 0,2 mm; D. 0,05 mm. 
Cerca de 30 dias após o aparecimento do calo embriogênico, verificou-se que o mesmo apresentou rápido desenvolvimento. Nesse período o calo embriogênico exibiu características morfológicas típicas, onde foi observado seu aspecto friável, consistência pouco aqueosa e cor amarelo intenso (Figura 7 A).

Anatomicamente, foi verificado que esse tipo de calo é constituído inteiramente de células pequenas, com 17 a $24 \mu \mathrm{m}$ de diâmetro, isodiamétricas, com citoplasma denso, paredes celulares delgadas, com aproximadamente $0,7 \mu \mathrm{m}$, além de núcleo proeminente, o que caracteriza claramente células meristemáticas (Figura 7 B-D). Várias células apresentaram dois núcleos em um mesmo citoplasma, evidenciando a citocinese ainda não concluída no processo de divisão celular (Figura $7 \mathrm{C}$, setas). Em determinadas regiões do calo embriogênico, o início da linearização das células foi constatado, o que sugere a organização celular envolvida no processo de formação de embriões (Figura $7 \mathrm{D}$, setas).

Em diversas espécies da família Arecaeae foram observados calos embriogênicos com células isodiamétricas, citoplasma denso e núcleo proeminente induzidos a partir de embriões zigóticos de Bactris gasipaes, Euterpe oleracea e Acrocomia aculeata (Moura et al., 2009; Maciel et al., 2010; Scherwinski-Pereira et al., 2012) e a partir de folhas imaturas de Phoenix dactylifera (Sané et al., 2006). Esse mesmo padrão de células meristemáticas também foi verificado na indução da embriogênese somática de dendezeiro (Touchet et al., 1991; Duval et al., 1995; Schwendiman et al., 1988; Scherwinski-Pereira et al., 2010; Pádua et al., 2013; Silva et al., 2014). 

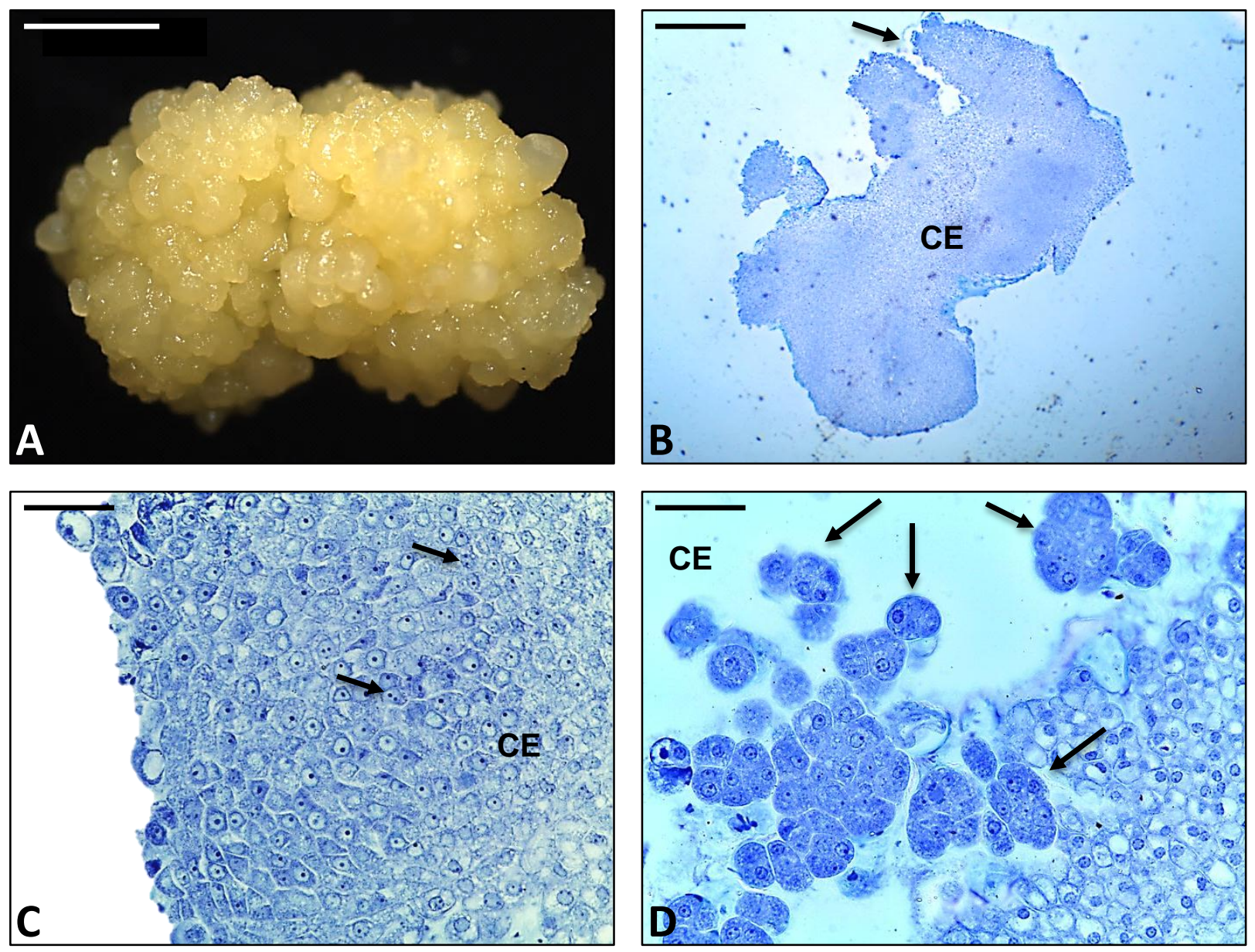

Figura 7. Aspectos morfológicos e anatômicos do calo embriogênico obtido a partir da indução de folhas jovens de dendezeiro (Elaeis guineensis Jacq.). A. Morfologia externa. B-D. Secção do calo embriogênico. C. Setas indicam divisão celular. B. Setas indicam a região em que foi observado o início de organização celular C. Setas indicam duplicidade de núcleos caracterizado pela intensa divisão celular. D. Setas indicam a linearização celular para a formação de embriões somáticos. Abreviações: $C E=$ calo embriogênico. Barras: A. 2 mm; B. 0,5 mm; C. 0,05 mm; D. 0,05 mm.

O modo de surgimento de embriões em calos embriogênicos foi detalhadamente estudado por Schwendiman et al. (1988, 1990) e Duval et al. (1995). Segundo esses autores, as células do calo evoluem para células que apresentam características típicas de células embrionárias: alta taxa de núcleos evidentes, núcleo central com nucléolo destacado, citoplasma denso e intensamente corado, iniciando o surgimento de aglomerados celulares. Esta última característica é denominada diferenciação e parece ser a primeira fase da formação do embrião somático. Este fenômeno é acompanhado por uma intensa multiplicação das células embriogênicas. A partir de então, os 
aglomerados de células crescem, desenvolvem uma protoderme e dão origem a estruturas denominadas proembriões, embrióides, ou embriões somáticos, onde a nomenclatura utilizada varia de acordo com os autores e, certamente, com a fase de desenvolvimento considerada. O processo inicial de formação dos embriões somáticos citado por esses autores, também pode ser verificado no presente trabalho com a organização das células meristemáticas do calo embriogênico (Figura 7 D). 


\section{CONCLUSÕES}

Com a indução da calogênese a partir de folhas imaturas de dendezeiro, verificase que o surgimento do calo ocorre a partir de células associadas aos feixes vasculares da folha. Esse processo causa o rompimento do mesofilo e a exposição de massas celulares que posteriormente irão constituir o calo primário. Observa-se que a maturidade do explante inicial influencia diretamente a indução de calo, onde folhas com feixes vasculares pouco desenvolvidos, em sua maioria, não apresentam formação de calo. A partir da utilização de ácido naftalenoacético (ANA), verifica-se também o surgimento de raízes pela rota da organogênese direta. Durante a indução da embriogênese somática de dendezeiro, observa-se a formação de dois tipos de calo: o calo primário, constituído por uma região periférica com células vacuoladas, uma região intermediária com células parenquimáticas e internamente por uma zona meristemática e o calo embriogênico, constituído por células meristemáticas. A partir do calo embriogênico, é verificada a formação de embriões somáticos, que se inicia com o isolamento e organização de células embrionárias. 


\section{REFERÊNCIAS BIBLIOGRÁFICAS}

AKIN, D. E.; ROBINSSON, E. L. Structure of leaves and stems of arrow leaf and crim son clovers as related to in vitro digestibility. Crop Sciences, v.22, p.24-29, 1982.

ALMEIDA, M.; ALMEIDA, C. V.; GRANER, E. M.; BRONDANI, G. E.; ABREU-TARAZI, M. F. Pre-procambial cells are niches for pluripotent and totipotent stem-like cells for organogenesis and somatic embryogenesis in the peach palm: a histological study. Plant Cell Report, v.31, p.1495-1515, 2012.

APPEZZATO-DA-GLÓRIA, B.; MACHADO, S. R. Ultrastructural analysis of in vitro direct and indirect organogenesis. Revista Brasileira de Botânica, v.27, p. 429-437, 2004.

BALZON, T. A.; LUIZ, Z. G.; SCHERWINSKI-PEREIRA, J. E. New approaches to improve the efficiency of somatic embryogenesis in oil palm (Elaeis guineensis Jacq.) from mature zygotic embryos. In Vitro Cellular and Developmental Biology - Plant, v.49, p.41-50, 2013.

BARBIER-BRYGOO, H.; EPHRITIKHINE, G.; KÄMBT, D.; GHISLAIN, M.; GUERN, J. Functional evidence for an auxin receptor at the plasmalemma of tobacco mesophyll protoplasts. Proceedings of the National Academy of Sciences, v.86, p.891-895, 1989.

BATAGIN-PIOTTO, K. D.; ALMEIDA, C. V.; PIOTTO, F. A.; ALMEIDA, M. Anatomical analysis of peach palm (Bactris gasipaes) leaves cultivated in vitro, ex vitro and in vivo. Brazilian Journal of Botany, v.35, p.71-78, 2012.

BIEYSSE, D.; GOFFLOT, A.; MICHAUX-FERRIÈRE, N. Effect of experimental conditions and genotypic variability on somatic embryogenesis in Coffea arabica. Canadian Journal of Botany v.71, p.1496-1502, 1993.

BUFFARD-MOREL, J.; VERDEIL, J. L.; PANNETIER, C. Embryogenèse somatique du cocotier (Cocos nucifera L.) à partir d'explants foliaires: étude histologique. Canadian Journal of Botany, v.70, p.735-741, 1992.

CORREDOIRA, E.; VALLADARES, S.; VIEITEZ, A. M. Morphohistological analysis of the origin and development of somatic embryos from leaves of mature Quercus robur. In Vitro Cellular and Developmental Biology - Plant, v.42, p.525-533, 2006.

DUVAL, Y.; ENGELMANN, F.; DURAND-GASSELIN, T. Somatic embryogenesis in oil palm (Elaeis guineensis Jacq). $1995 \mathrm{In}$ : Biotechnology in Agriculture and Forestry: Somatic Embryogenesis and Synthetic Seed, Y.P.S. Bajaj (Eds.), p.335-352, 1995.

EL-BAHR, M. K.; ALI, Z. A.; SAKER, M. M. A comparative anatomical study of date palm vitroplants. Arab Journal of Biotechnology, v.7, p.219-228, 2004.

ELMEER, K. E. S. Factors regulating somatic embryogenesis in plants. In: ASLAM, J.; SRIVASTAVA, P. S.; SHARMA, M. P. (Eds.) Somatic embryogenesis and gene expression. New Delhi: Narosa Publishing House, p.56-81, 2013. 
GAWEL, N. J.; RAO, A. P.; ROBACKER, C. D. Somatic embryogenesis from leaf and petiole callus cultures of Gossypium hirsutum L. Plant Cell Reports, v.5, p.457-459, 1986.

GOLDSWORTHY, A.; RATHORE, K. S. The Electrical Control of Growth in Plant Tissue 7. Journal of experimental botany, v.36, p.1134-1141, 1985.

GUEYE, B.; MORCILLO, F.; COLLIN, M.; GARGANI, D.; OVERVOORDE, P.; ABERLENC-BERTOSSI, F.; VERDEIL, J. L. Acquisition of callogenic capacity in date palm leaf tissues in response to 2, 4-D treatment. Plant Cell, Tissue and Organ Culture, v.99, p.35-45, 2009.

HABIB, S. H.; SYED-ALWEE, S. S. R.; HO, C. L.; ONG-ABDULLAH, M.; SINNIAH, U. R.; NAMASIVAYAM, P. Morpho-histological characterization of truncated leaf syndrome seedlings: an oil palm (E. guineensis Jacq.) somaclonal variant. Acta Physiologiae Plantarum, v.34, p.17-28, 2012.

HANSEN, S.B.; PADFIELD, R.; SYAYUTI, K.; EVERS, S.; ZAKARIAH, Z.; MASTURA, $S$. Trends in global palm oil sustainability research. Journal of Cleaner Production, v.100, p.140-149, 2015.

JALIGOT E, ADLER S, DEBLADIS E, BEULE T, RICHAUD F, ILBERT P, FINNEGAN EJ, RIVAL A Epigenetic imbalance and the floral developmental abnormality of the in vitro-regenerated oil palm Elaeis guineensis. Ann Bot v.108, p.1453-1462, 2011.

JOHANSEN, D. A. Plant microtechnique. McGraw-Hill, New York, 1940.

JONES, L. H. The oil palm and its clonal propagation by tissue culture. Biologist, v.30, p.181-188, 1983.

JOUANNIC, S.; ARGOUT, X.; LECHAUVE, F.; FIZAMES, C.; BORGEL, A.; MORCILLO, F.; ABERLENC-BERTOSSI, F.; DUVAL, Y.; TREGEAR, J. Analysis of expressed sequence tags from oil palm (Elaeis guineensis). FEBS Lett v.579, p.27092714, 2005.

KARAMI, O.; SAIDI, E. A. The molecular basis for stress-induced acquisition of somatic embryogenesis. Mol Biol Rep v.37, p.2493-2507, 2010.

KARUN, A.; SIRIL, E. A.; RADHA, E.; PARTHASARATHY, V. A. Somatic embryogenesis and plantlet regeneration from leaf and inflorescence explants of arecanut (Areca catechu L.). Current Science, v.86, p.25, 2004.

LOISEAU, J.; CLAIRE, M.; YVON, L. D. Effects of auxins, cytokinins, carbohydrates and amino acids on somatic embryogenesis induction from shoot apices of pea. Plant Cell, Tissue and Organ Culture, v.41, p.267-275, 1995.

LUIS, Z. G.; BEZERRA, K. M. G.; SCHERWINSKI-PEREIRA, J. E. Adaptability and leaf anatomical features in oil palm seedlings produced by embryo rescue and pregerminated seeds. Brazilian Journal of Plant Physiology, v.22, p.209-215, 2010. 
MACIEL, S. A.; JUNIOR, P. C. P. F.; SILVA, R. A.; SCHERWINSKI-PEREIRA, J. E. Morpho-anatomical characterization of embryogenic calluses from immature zygotic embryo of peach palm during somatic embryogenesis. Acta Scientiarum. Agronomy, v.32, p.263-267, 2010.

MATSUOKA, H.; HINATA, K. NAA-Induced Organogenesis and Embryogenesis in Hypocotyl Callus of Solarium melongena L. Journal of Experimental Botany, v.30, p.363-370, 1979.

MICHAUX-FERRIÈRE, N.; DUBLIN, P.; SCHWENDIMAN, J. Éstude histologique de l'embryogenese somatique à partir d'explants foliares de Coffea arabica L.. Café, Cacao e Thé, v.31, p.103-111, 1987.

MICHAUX-FERRIÈRE, N.; BIEYSSE, D.; ALVARD, D.; DUBLIN, P. Éstude histologique de l'embryogenese somatique chez Coffea arabica, induite par culture sur milieux uniques de fragments foliares de génotypes différents. Café, Cacao e Thé, v.33, p.207213, 1989.

MOURA, E. F.; VENTRELLA, M. C.; MOTOIKE, S. Y.; JUNIOR, A. Q. S.; CARVALHO, M.; MANFIO, C. E. Histological study of somatic embryogenesis induction on zygotic embryos of macaw palm (Acrocomia aculeate (Jacq.) Lodd. ex Martius). Plant Cell, Tissue and Organ Culture, v.95, p.175-184, 2008.

MOURA, E. F.; MOTOIKE, S. Y.; VENTRELLA, M. C.; JÚNIOR SÁ, A. Q.; CARVALHO, $M$. Somatic embryogenesis in macaw palm (Acrocomia aculeata) from zygotic embryos. Scientia Horticulturae, v.119, p.447-454, 2009.

MOYO, M.; AREMU, A. O.; VAN STADEN, J. Insights into the multifaceted application of microscopic techniques in plant tissue culture systems. Planta, v.242, p.773-790, 2015.

MUCHOW, R. C.; SINCLAIR, T. R. Epidermal conductance, stomatal density and stomatal size among genotypes of Sorghum-bicolor (L.) Moench. Plant, Cell \& Environment, v.12, p.425-431, 1989.

MUKHERJEE, I.; SOVACOOL, B.K. Palm oil-based biofuels and sustainability in southeast Asia: A review of Indonesia, Malaysia, and Thailand. Renewable and Sustainable Energy Reviews, v.37, p.1-12, 2014.

OOI, S. E.; CHOO, C. N.; ISHAK, Z.; ONG-ABDULLAH, M.; A. Candidate auxinresponsive expression marker gene, EgIAA9, for somatic embryogenesis in oil palm (Elaeis guineensis Jacq.). Plant Cell, Tissue and Organ Culture. v.110, p.201-202, 2012.

PÁDUA, M. S.; PAIVA, L. V.; LABORY, C. R. G.; ALVES, E.; STEIN, V. C. Induction and characterization of oil palm (Elaeis guineensis Jacq.) pro-embryogenic masses. Anais da Academia Brasileira de Ciências, v.85, p.1545-1556, 2013. 
PEARCE, D. W.; MILLARD, S.; BRAY, D. F.; ROOD, S. B. Stomatal characteristics of riparian poplar species in a semi-arid environment. Tree Physiology. v.26, p.211-218, 2005.

PORTILLO, L.; SANTACRUZ-RUVALCABA, F.; GUTIÉRREZ-MORA, A.; RODRÍGUEZGARAY, B. Somatic embryogenesis in Weber cultivar azul. In Vitro Cellular \& Developmental Biology - Plant, v.43, p.569-575, 2007.

REINERT, J. Morphogenese und ihre kontrolle an geweberkulturen aus karotten. Naturwissenschsften, v.45, p.344-345, 1958.

ROSE, R. J.; WANG, X. D.; NOLAN, K. E.; ROLFE, B. G. Root meristems in Medicago truncatula tissue culture arise from vascular-derived procambial-like cells in a process regulated by ethylene. Journal of Experimental Botany, v.57, p.2227-2235, 2006.

SANÉ, D.; BORGEL, A.; CHEVALLIER, M. H.; GASSAMA-DIA, Y. K. Induction in vitro de l'enracinement de microboutures d'Acacia tortilis subsp. raddiana par traitement transitoire à l'auxine. Annals of forest science, v.58, p.431-437, 2000.

SANÉ, D.; ABERLENC-BERTOSSI, F.; GASSAMA-DIA, Y. K.; SAGNA, M.; TROUSLOT, M. F.; DUVAL, Y.; BORGEL, A. Histocytological analysis of callogenesis and somatic embryogenesis from cell suspensions of date palm (Phoenix dactylifera). Annal of Botany, v.98. p.301-308, 2006.

SANÉ, D.; ABERLENC-BERTOSSI, F.; DIATTA, L. I. D.; GUÈYE, B.; DAHER, A.; SAGNA, M.; DUVAL, Y.; BORGEL, A. Influence of growth regulators on callogenesis and somatic embryo development in date palm (Phoenix dactylifera L.) Sahelian cultivars. The Scientific World Journal, DOI:10.1100/2012/837395, 2012.

SANTOS, K. G. B.; MARIATH, J. E. A.; MOÇO, M. C. C.; BODANESE-ZANETTINI, H. Somatic embryogenesis from immature cotyledons of soybean (Glycine max (L.) Merr.): ontogeny of somatic embryos. Brazilian Archives Biology Technology v.49, p.49-55, 2006 .

SCHERWINSKI-PEREIRA, J. E.; GUEDES, R. S., SILVA, T. L.; FERMINO, J. P.; COSTA, F. S. Somatic embryogenesis and plant regeneration from oil palm thin cell layer. In Vitro Cellular and Development Biology, v.46, p.378-385, 2010.

SCHERWINSKI-PEREIRA, J. E.; GUEDES, R. S.; SILVA, R. A.; POETA, P. C.; FERMINO, J. R. P. C. P.; LUIS, Z. G.; FREITAS, E. O. Somatic embryogenesis and plant regeneration in açaí palm (Euterpe oleracea). Plant Cell, Tissue and Organ Culture, v.109, p.501-508, 2012.

SCHWENDIMAN, J.; PANNETIER, C.; N. MICHAUX-FERRIERE Histology of Somatic Embryogenesis from Leaf Explants of the Oil Palm Elaeis guineensis. Annals of Botany, v.62, p.43-52, 1988.

SCHWENDIMAN, J.; PANNETIER, C.; MICHAUX-FERRIÈRE N. Histology of embryogenic formations during in vitro culture of oil palm Elaeis guineensis Jacq. Oléagineux, v.45, p.409-418, 1990. 
SILVA, R. C.; LUIS, Z. G.; SCHERWINSKI-PEREIRA, J. E. Differential responses to somatic embryogenesis of different genotypes of Brazilian oil palm (Elaeis guineensis Jacq.). Plant Cell, Tissue and Organ Culture, v.111, p.59-67, 2012.

SILVA, R. C.; CARMO, L. S. C.; LUIS, Z. G. L.; SILVA, L. P.; SCHERWINSKIPEREIRA, J. E.; MEHTA, A. Proteomic identification of differentially expressed proteins during the acquisition of somatic embryogenesis in oil palm (Elaeis guineensis Jacq.). Journal of Proteomics, v.104, p.112-127, 2014.

SOH, A. C.; WONG, G.; TAN, C. C.; CHEW, P. S.; CHONG, S. P.; HO, Y. W.; WONG, C. K.; CHOO, C. N.; NOR-AZURA, H.; KUMAR, K. Commercial-scale propagation and planting of elite oil palm clones: research and development towards realization. Journal of Oil Palm Research, v.23, p.935-952, 2011.

STAUFFER, F. W.; ASMUSSEN, C. B.; HENDERSON, A.; ENDRESS, P. K. A revision of Asterogyne (Arecaceae: Arecoideae: Geonomeae). Brittonia, v.55, p.326-356, 2003.

STEINMACHER, D. A.; KROHN, N. G.; DANTAS, A. C. M.; STEFENON, V. M.; CLEMENT, C. R.; GUERRA, M. P. Somatic embryogenesis in peach palm using the thin cell layer technique: induction, morpho-histological aspects and AFLP analysis of somaclonal variation. Annals of Botany, v.100, p.1-11, 2007.

STEINMACHER, D. A.; GUERRA, M. P.; SAARE-SURMINSKI, K.; LIEBEREI, R. A temporary immersion system improves in vitro regeneration of Peach palm through secondary somatic embryogenesis. Annals of Botany, v.108, p.1463-1475, 2011.

STIPP, L. C. L.; MENDES, B. M. J.; PIEDADE, S. M. D. S.; RODRIGUEZ, A. P. M. In vitro morphogenesis of Cucumis melo var. inodorus. Plant, Cell, Tissue and Organ Culture, v.65, p.81-89, 2001.

TOMLINSON, P. B. The structural biology of palms. Oxford University Press. 1990.

TOUCHET, B. D.; DUVAL, Y.; PANNETIER, C. Plant regeneration from embryogenic suspension culture of oil palm (Elaeis guineensis Jacq). Plant Cell Reports. v.10, p.529-532, 1991.

TREGEAR, J. W.; RIVAL, A.; PINTAUD, J. C. A family portrait: unravelling the complexities of palms. Annals of Botany, v.108, p.1387-1389, 2011.

TROLINDER, N. L.; XHIXIAN, C. Genotype specificity of the somatic embryogenesis response in cotton. Plant Cell Reports, v.8, p.133-136, 1989.

VALOIS, A. C. C. Possibilidades da cultura do dendê na Amazônia. Brasília: Embrapa-Cernagen, Comunicado Técnico, v.19. 1997.

VERDEIL, J. P.; HOCHER, V.; HUET, C.; GROSDEMANGE, F.; ESCOUTE, J.; FERRIERE, N.; NICOLE, M. Ultrastructural changes in coconut calli associated with the acquisition of embryogenic competence. Annals of Botany, v.88, p.9-18, 2001. 
WILLIAMS, E. S.; MAHESWARAN, B. Somatic Embryogenesis: factors influencing coordinated behavior of cells as an embryogenic group. Annals of Botany, v.57, p.443462, 1986. 


\section{CAPÍTULO 3}

CARACTERIZAÇÃO BIOQUIIMICA DOS ESTÁGIOS INICIAIS DE DESENVOLVIMENTO DA EMBRIOGÊNESE SOMÁTICA DE FOLHAS IMATURAS DE PLANTAS ADULTAS DE DENDEZEIRO (Elaeis guineensis Jacq.) 


\section{RESUMO}

O objetivo do trabalho foi avaliar o comportamento fisiológico e bioquímico envolvidos na indução de linhagens embriogênicas originadas a partir de folhas imaturas de plantas adultas de dendezeiro de alto rendimento. Para tanto, os açúcares, amido, ácidos graxos, aminoácidos e proteínas, além da análise do perfil metabólico foram determinados em folhas com zero dias de cultivo (controle), folhas que não reagiram, folhas com raizes, folhas com calos, calos primários e calos embriogênicos do genótipo B35-17-33. Verificou-se que não houve diferenças significativas entre as concentrações de açúcares nos segmentos foliares de dendezeiro que se mostraram responsivos ou não à da indução da embriogênese somática. Em contrapartida, folhas com calos apresentaram níveis inferiores de frutose, juntamente com uma maior concentração de amido quando comparadas com folhas que não reagiram. Com relação aos diferentes tipos de calo, verificou-se diferença considerável entre eles, onde calos primários apresentaram maiores concentrações de açúcares e amido, quando comparados com calos embriogênicos, diferindo também em uma maior concentração de sacarose no calo primário. Com relação aos ácidos graxos, não houve diferenças significativas entre as folhas com calos e àquelas que não reagiram. Já nos calos o resultado observado foi oposto ao verificado em relação aos açúcares e amido, pois, nesse caso, o calo embriogênico apresentou níveis superiores de ácidos graxos. Verificou-se que, de forma geral, os lipídios que compõem os explantes em desenvolvimento são compostos em sua maior parte pelo ácido palmítico e pelo ácido linoléico. Os teores de aminoácidos apresentaram acúmulo gradativo nas etapas da indução. Para estes compostos, folhas com zero dias (controle) e folhas com calo não diferiram estatisticamente entre si e apresentaram concentrações superiores às observadas nas folhas que não reagiram e nas folhas com raízes, com os teores aumentando nos calos primários e, principalmente, nos calos embriogênicos. Em todas as fases avaliadas, apenas os calos embriogênicos apresentaram maior concentração de prolina. Em relação às proteínas totais, folhas com zero dias e folhas que não reagiram apresentaram níveis intermediários deste composto, com taxas reduzidas até a formação do calo primário e aumentadas no calo embriogênico.

Palavras-chave: Arecaceae; cultivo in vitro; morfogênese; metabolismo; fisiologia; bioquímica. 


\section{ABSTRACT}

The goal of the project was evaluating the physiologic and biochemical behavior involved on the embryogenic lineage spread induction originally from high performance African oil palm tree adult plant's half-grown leaves. Therefore, sugars, amine, fatty acids, amino acids and proteins, besides the metabolic profile analysis were determined on zero cultivation days leaves (control), leaves that didn't react, leaves with roots, leaves with calluses, primary calluses and embryogenic calluses from B35-17-33 genotype. It was verified that there were no significant differences between the sugar concentration on foliar segments of the African oil palm tree that showed to be responsive or not to somatic embryogenesis induction. In return, leaves with calluses presented lower fructose level, along with a higher amine concentration when compared to leaves that didn't react. Regarding the different types of callus, it was seen a major difference between them, where the primary calluses presented higher concentrations of sugars and amine, when compared to embryogenic calluses, also differing on a higher sucrose on the primary callus. Regarding the fatty acids, there weren't significant differences among the leaves with calluses and those which didn't react. In the calluses the result observed was contrary compared to the one verified involving the sugars and amine, since, in this case, the embryogenic callus presented higher fatty acids levels. It was seen that, on the whole, the lipids that form the developing explant are composed mostly by the palmitic acid and the linoleic acid. The amino acids levels presented gradual increase on the induction steps. For those compounds, leaves with zero days (control) and leaves with callus didn't differ statistically among themselves and presented higher concentrations to those seen on leaves that didn't react and leaves with roots, with increasing levels on the primary calluses and, especially, on the embryogenic calluses. On all evaluated stages, only the embryogenic calluses presented higher concentration of proline. Regarding the total proteins, leaves with zero days that didn't react presented intermediary levels of this compound, with reduced rates up to the primary callus formation and enhanced on the embryogenic callus.

Keywords: Arecaceae; in vitro growth; morphogenesis; metabolism; physiology; biochemestry. 


\section{INTRODUÇÃO}

O dendezeiro (Elaeis guineensis Jacq.) é uma palmeira oleaginosa de origem africana, largamente cultivada em regiões de clima tropical úmido. O principal produto do dendezeiro é o óleo extraído da polpa do fruto, conhecido internacionalmente como óleo de palma. Atualmente, o óleo de palma é um dos mais produzidos e consumidos no mundo, apresentando usos alimentício, medicinal e oleoquímico. Visando explorar o potencial oleaginoso da espécie para atender ao mercado econômico, os programas de melhoramento genético têm trabalhado características de interesse comercial (Mukherjee \& Sovacool, 2014; Hansen et al., 2015).

Atualmente, os programas de melhoramento genético possuem dendezeiros elite que apresentam características de interesse agronômico que oferecem grande potencial para melhorar a competitividade e sustentabilidade da cultura, com alto potencial de produção (Rey et al., 2004).

Diante disso, existe a preocupação quanto à propagação de genótipos elite de dendezeiro, isso por que, nos poucos programas de melhoramento genético da espécie existentes, a multiplicação de genótipos selecionados se dá exclusivamente por meio de sementes, fato que na ausência de métodos adequados de clonagem por métodos convencionais, torna praticamente impossível a obtenção de culturas uniformes e a perpetuação das características de um indivíduo de alto valor genético selecionado (Corley \& Tinker, 2003). Portanto, torna-se imperativo que se avance nas pesquisas para a obtenção de protocolos seguros e confiáveis para a propagação clonal em larga escala de materiais superiores a partir de tecidos somáticos, tais como, folhas jovens.

De fato, a propagação in vitro apresenta-se como uma das únicas alternativas para a propagação vegetativa do dendezeiro. Nesse contexto, diversos trabalhos demonstram que tecidos foliares cultivados in vitro, na presença de reguladores de crescimento, como auxinas e citocininas, são capazes de induzir embriões somáticos (Gantait et al., 2015). Além das alterações morfológicas deste processo, ocorrem mudanças na síntese de substâncias que são importantes sinalizadoras, e/ou reservas para a completa formação de uma planta. Sendo assim, o estudo dos eventos bioquímicos durante todas as etapas da embriogênese somática são de extrema importância para a otimização de protocolos de propagação em larga escala da espécie (Fritsche-Neto, 2012). 
Diante disso, esta pesquisa visa avaliar o comportamento fisiológico e bioquímico envolvidos na indução de linhagens embriogênicas de dendezeiros originadas a partir de folhas imaturas de plantas adultas de alto rendimento. 


\section{MATERIAL E MÉTODOS}

\subsection{Local de realização dos experimentos}

O experimento foi conduzido no Laboratório de Bioquímica Vegetal (LBV) do Departamento de Botânica da Universidade de Brasília, situado em Brasília - DF, Brasil e no Laboratório de Cultura de Tecidos Vegetais (LCT-II) da Embrapa Recursos Genéticos e Biotecnologia, situado em Brasília - DF, Brasil.

\subsection{Obtenção do material vegetal}

Para a indução da embriogênese somática foram utilizadas como material vegetal, folhas imaturas e ainda não expandidas (palmito), oriundas de plantas adultas de dendezeiros variedade B35-1733, fornecidas pelo Programa de Melhoramento Genético de Dendezeiro da Embrapa Amazônia Ocidental, a partir do Banco de Germoplasma da espécie localizado na municipalidade de Rio Preto da Eva - AM, Brasil.

Após coletado em campo, o material vegetal foi conduzido ao laboratório, onde as folhas mais externas foram removidas e o tamanho do palmito reduzido para aproximadamente $30 \mathrm{~cm}$ de comprimento da região basal meristemática (próxima ao meristema) até o ápice foliar do cilindro central (região mais afastada do meristema).

A indução da embriogênese somática foi realizada a partir da inoculação de segmentos foliares em placas de Petri $(15 \times 90 \mathrm{~mm})$ contendo meio de cultura composto pela constituição salina e vitaminas de MS (Murashige \& Skoog, 1962), suplementado com 0,5 g. $\mathrm{L}^{-1}$ de caseína hidrolisada, 0,5 g. $\mathrm{L}^{-1}$ de glutamina, 2,5 g. $\mathrm{L}^{-1}$ de carvão ativado, $30 \mathrm{~g} \cdot \mathrm{L}^{-1}$ de sacarose, $2,5 \mathrm{~g} \cdot \mathrm{L}^{-1}$ de Phytagel e $225 \mu \mathrm{m}$ de Picloram. $\mathrm{O} \mathrm{pH}$ dos meios foi ajustado para $5,7 \pm 0,1$ sendo autoclavados à temperatura de $121^{\circ} \mathrm{C} \mathrm{e}$ pressão de 1,5 atm por 20 minutos.

Foram inoculados seis segmentos de folhas jovens de aproximadamente $1 \mathrm{~cm}^{2}$, provenientes das regiões apical e basal dos palmitos, com a face adaxial em contato com o meio de cultura, em placas de Petri contendo $25 \mathrm{~mL}$ de meio nutritivo. Todos os experimentos foram mantidos em sala de crescimento sob temperatura de $25 \pm 2 \stackrel{\circ}{\circ} \mathrm{C}$ acondicionados no escuro. 
Nestas condições de cultivo, os explantes foram mantidos por três subcultivos de 60 dias cada para a obtenção de calos primários e mais um subcultivo de 90 dias para a obtenção de calos embriogênicos.

\subsection{Caracterização bioquímica dos estádios de desenvolvimento}

Para a caracterização bioquímica das fases de indução e multiplicação de linhagens embriogênicas os açúcares totais solúveis, o amido, os ácidos graxos, as proteínas totais, os aminoácidos totais livres e o perfil metabólico foram determinados de folhas aos zero dias de cultivo, folhas que não reagiram, folhas com raizes, folhas contendo calo, calos primários isolados e calos embriogênicos (Figura 1).
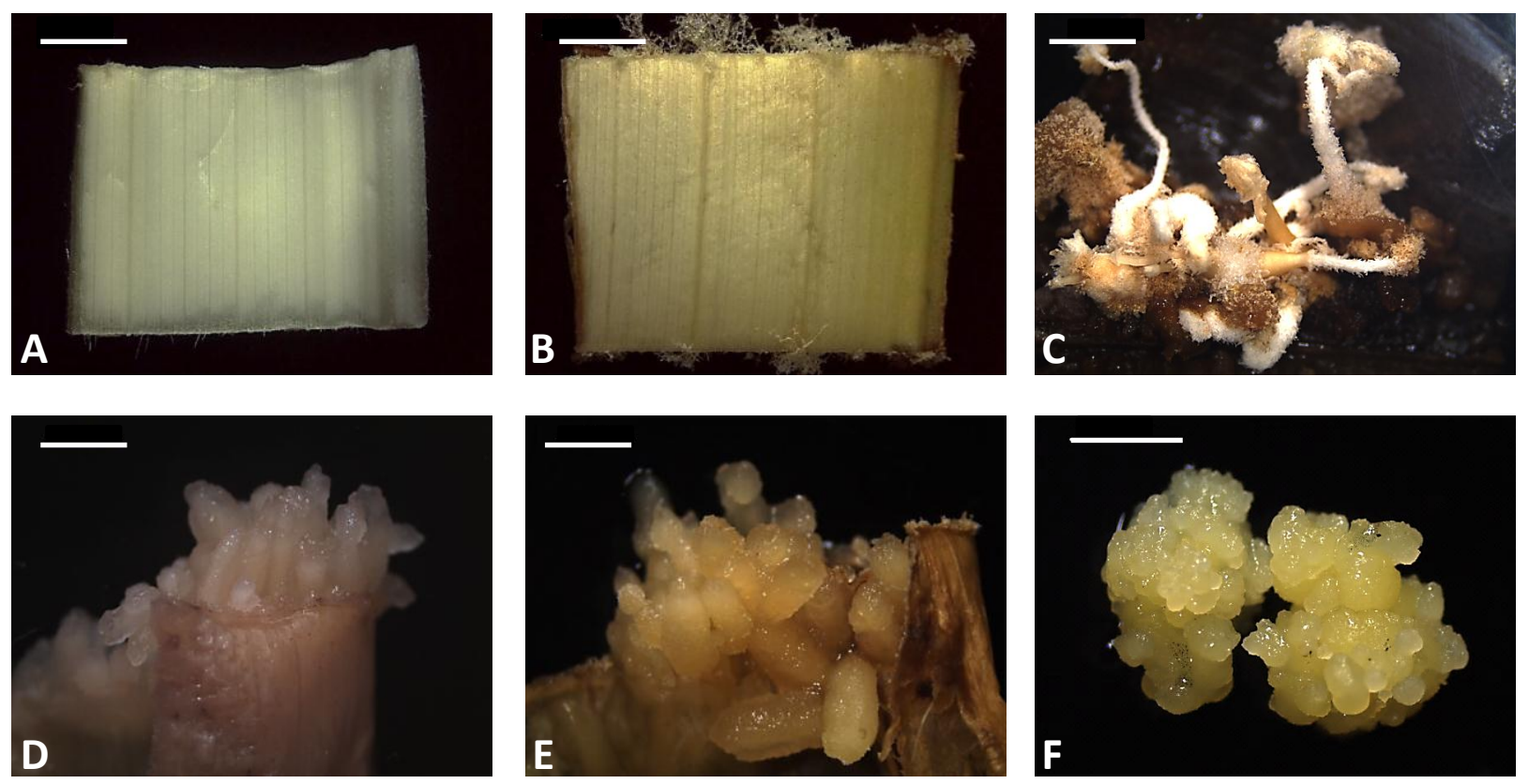

Figura 1. Aspecto morfológico dos estádios de indução e multiplicação utilizados na caracterização bioquímica da embriogênese somática de folhas imaturas de dendezeiro (Elaeis guineensis Jacq.). A. Folha com zero dias de cultivo (controle); B. Folha que não reagiu; C. Folha com raiz; D. Folha contendo calo; E. Calo primário isolado; F. Calo embriogênico. Barras: $2 \mathrm{~mm}$.

Para tanto, as amostras coletadas em cada um dos estádios foram imediatamente congeladas em nitrogênio líquido e armazenadas em câmaras $-80 \stackrel{\circ}{\mathrm{C}}$. Posteriormente, foram liofilizadas por 48 horas e maceradas em almofariz, seguindo a 
metodologia descrita por Gomes et al. (2014). Cada tratamento foi composto por três repetições. Os dados obtidos foram submetidos à análise de variância (ANOVA) com as médias comparadas pelo teste de Tukey a $5 \%$ de probabilidade. Para as análises utilizou-se o programa de análises estatísticas Sisvar 4.4. Dados obtidos por contagem foram transformados segundo $(x+1)^{0,5}$.

\subsubsection{Açúcares solúveis}

A extração dos açúcares totais solúveis foi realizada segundo a metodologia modificada de Gomes et al. (2014). Para isto, $10 \mathrm{mg}$ de massa seca das amostras foram inoculadas em tubos plásticos de $2 \mathrm{~mL}$ de capacidade, e submetidas à extração em $0,5 \mathrm{~mL}$ de etanol $80 \%$ a $80 \stackrel{\circ}{\mathrm{C}}$ por 20 minutos. Após a incubação, os tubos foram centrifugados a $13.000 \mathrm{rpm}$ (microcentrífuga modelo Eppendorf) por 10 minutos e os sobrenadantes foram coletados. Os resíduos foram re-extraídos mais três vezes e novamente centrifugados, com os sobrenadantes das quatro extrações etanólicas reunidos em novos tubos plásticos, totalizando $2 \mathrm{~mL}$ de sobrenadante. Os tubos contendo os sobrenadantes foram submetidos à secagem em Speed Vac $40{ }^{\circ} \mathrm{C}$ e $\mathrm{O}$ produto da secagem foi ressuspendido em $750 \mu \mathrm{L}$ de água ultra pura.

O extrato foi purificado em colunas de troca iônica, utilizando-se a resina catiônica Dowex 50x8 (100-200 mesh) para remoção dos aminoácidos e outros cátions, e a resina aniônica Dowex 1x8 (52-100 mesh) para remoção de ácidos orgânicos e outros ânions e água ultra pura para eluição dos extratos. Para a montagem das colunas foi pipetado $0,5 \mathrm{~mL}$ de resina de troca catiônica dentro de ponteiras de $1000 \mu \mathrm{L}$ de capacidade contendo uma fina camada de lã de vidro, aguardando-se a drenagem do excesso de líquido da coluna.

As colunas foram então posicionadas acima de tubos plásticos de $5 \mathrm{~mL}$ de capacidade. Foram adicionados $750 \mu \mathrm{L}$ das amostras e, quando necessário, as colunas tiveram seus $\mathrm{pHs}$ ajustados com $\mathrm{HCl} 2 \mathrm{M}$ para uma faixa de 3 a 6 . Após a drenagem das amostras, as colunas foram lavadas três vezes com $833 \mu \mathrm{L}$ de água ultrapura, totalizando um extrato de aproximadamente $3 \mathrm{~mL}$. Após a purificação, as amostras foram congeladas, liofilizadas por 48 horas e ressuspendidas em $1 \mathrm{~mL}$ de água ultrapura. 
Os carboidratos purificados foram quantificados de acordo com o método fenolsulfúrico, descrito por Dubois (1956). Foram pipetados $33 \mu \mathrm{L}$ das amostras em tubos de ensaio e adicionados $467 \mu \mathrm{L}$ de água ultrapura, $500 \mu \mathrm{L}$ de solução de fenol $5 \% \mathrm{e}$ $2,5 \mathrm{~mL}$ de ácido sulfúrico concentrado. Após 5 minutos de repouso em temperatura ambiente, foi realizada a leitura das absorbâncias em espectrofotômetro a $490 \mathrm{~nm}$. Como tratamento controle foi utilizada uma solução com $0,5 \mathrm{~mL}$ de água ultrapura, 0,5 $\mathrm{mL}$ de solução de fenol $5 \%$ e 2,5 mL de ácido sulfúrico concentrado. Todas as análises foram realizadas em triplicata e quantificadas com base na curva padrão da glucose, com concentrações de 0,$0 ; 5,0 ; 10 ; 20 ; 40$ e $80 \mu \mathrm{g}$.

As amostras foram liofilizadas por 48 horas e ressuspensas em $1 \mathrm{~mL}$ de água ultrapura. A composição dos açúcares totais solúveis foi determinada por cromatografia de troca iônica de alto desempenho com detector de pulso amperométrico (HPAECIPAD modelo ICS3000, marca Dionex Sunnyvale, Califórnia) com coluna CarboPac ${ }^{\mathrm{TM}}$ PA10 (2 x 250 mm) (Dionex Corp, Sunnyvale, CA, USA), usando-se eluição isocrática de $200 \mathrm{mM} \mathrm{NaOH}$ (24\%) em água (76\%) nem um fluxo de 0,2 mL por minuto durante 35 minutos. As respostas do detector foram comparadas com os padrões de glucose, frutose e sacarose a 0,3125; 0,625; 1,25; 2,5; 5; 10, 20 e $40 \mu \mathrm{g}$. A curva-padrão para cada açúcar foi usada para calcular os conteúdos de carboidratos nas amostras no Chromeleon Software.

\subsubsection{Amido}

A extração e quantificação do amido foi realizada segundo o método enzimático de Amaral et al. (2007). Para tanto, $10 \mathrm{mg}$ de massa seca das amostras foram colocadas em tubos plásticos de $2 \mathrm{~mL}$ de capacidade e submetidas à remoção dos açúcares em $0,5 \mathrm{~mL}$ de etanol $80 \%$ a $80 \stackrel{\circ}{\mathrm{C}}$ por 20 minutos. Após a incubação, os tubos foram centrifugados a 13.000 rpm em microcentrífuga modelo Eppendorf por 10 minutos, sendo os sobrenadantes descartados e os resíduos submetidos à remoção dos açúcares por mais três vezes. Em seguida, o resíduo foi seco em Speed Vac a 40 $\stackrel{\circ}{C}$.

Às amostras liofilizadas foram adicionados 0,5 mL (120 U. $\left.\mathrm{mL}^{-1}\right)$ de alfa-amilase termoestável do Bacillus licheniformis (Megazyme ${ }^{\circledR}$ ), diluída em tampão MOPS (ácido 3-(n-morfolino) propanosulfônico) $10 \mathrm{mM} \mathrm{pH} \mathrm{6,5.} \mathrm{Em} \mathrm{seguida,} \mathrm{as} \mathrm{amostras} \mathrm{foram}$ incubadas a $75^{\circ} \mathrm{C}$ por 30 minutos. Este procedimento foi repetido mais uma vez, 
totalizando 120 unidades de enzima. Posteriormente, as amostras foram resfriadas até $50 \stackrel{\circ}{\circ}$ (em banho-maria), sendo então adicionada uma solução contendo $0,5 \mathrm{~mL}$ (30 U. $\mathrm{mL}^{-1}$ ) de amiloglucosidase (AMG) de Aspergillus niger (Megazyme ${ }^{\circledR}$ ), em tampão acetato de sódio $100 \mathrm{mM}, \mathrm{pH} 4,5$, seguido pela incubação das amostras a $50 \stackrel{\circ}{\mathrm{C}}$ por 30 minutos. Este procedimento foi repetido mais uma vez, totalizando 30 unidades de enzima.

Após as quatro incubações, foram acrescentados $100 \mu \mathrm{L}$ de ácido perclórico 0,8 M para interromper a reação e precipitar proteínas. Após rápida centrifugação a 10.000 rpm por 2 minutos, alíquotas de $20 \mu \mathrm{L}$ das amostras foram pipetadas em microplacas e incubadas por 15 minutos a $37^{\circ} \mathrm{C}$ com $300 \mu \mathrm{L}$ de solução GODPOD (Glicose PAP Liquiform/ Centerlab ${ }^{\circledR}$ ). Após a incubação, o teor de amido foi determinado leitor de microplacas Elisa a $510 \mathrm{~nm}$. Todas as análises foram realizadas em triplicata com base na curva padrão da glucose com concentrações de 0,0; 0,625; 1,25; 2,5; 5,0 e $10 \mu \mathrm{g}$.

\subsection{3. Ácidos graxos (ésteres metílicos de ácidos graxos)}

A derivatização e quantificação dos ácidos graxos foi realizada seguindo a metodologia descrita por Laurens et al. (2012). Para tanto, $5 \mathrm{mg}$ de massa seca das amostras foram inoculadas em vials de vidro, onde foram adicionados $200 \mu \mathrm{L}$ de metanol/clorofórmio $(1: 2 \mathrm{v} / \mathrm{v})$ e $300 \mu \mathrm{L}$ de $\mathrm{HCl} 5 \%$ em metanol. Após 1 hora de incubação em banho seco a $85^{\circ} \mathrm{C}, 1 \mathrm{~mL}$ de hexano foi então acrescido às amostras. Em seguida, o extrato foi agitado levemente por 1 hora e a fase superior resultante transferida cuidadosamente para novos vials de vidro.

Posteriormente, as amostras foram analisadas por cromatografia gasosa acoplada à espectrometria de massas (Agilent $\AA$, 7890-5975), utilizando-se uma coluna de 30 metros do tipo INNOWAX. Em seguida, os ácidos graxos presentes nas amostras foram identificados com o auxílio da biblioteca NIST. Por fim, os ácidos graxos existentes nos cultivos foram então quantificados comparando-se suas respostas com o padrão Grain Fatty Acid Methyl Ester Mix da Supelco Analytical®.

\subsubsection{Aminoácidos livres}

A extração e quantificação dos aminoácidos livres se deu de acordo com o protocolo de Yemm \& Cocking (1955) com modificações. Para tanto, 10 mg de massa 
seca das amostras foram inoculadas em microtubos de $2 \mathrm{~mL}$ de capacidade e submetidas à quatro extrações em $0,5 \mathrm{~mL}$ de etanol $80 \%$ a $80^{\circ} \mathrm{C}$ por 20 minutos. Após cada extração, as amostras foram centrifugadas a 13.000 rpm por 10 minutos e os sobrenadantes coletados em novos microtubos.

Em seguida, os sobrenadantes foram submetidos à secagem em speed vac a $40^{\circ} \mathrm{C}$ e o produto da secagem ressuspendido em $750 \mu \mathrm{L}$ de água ultra pura. Posteriormente, os extratos foram purificados em coluna de troca iônica, utilizando-se a resina catiônica Dowex 50x8 (100-200 mesh) para separação dos aminoácidos dos açúcares solúveis. Após esse processo, as amostras foram congeladas, liofilizadas por 48 horas e ressuspendidas em $0,5 \mathrm{~mL}$ de etanol $80 \%$.

Então, para quantificação dos aminoácidos totais livres, em $10 \mu \mathrm{L}$ de amostra foram adicionados $40 \mu \mathrm{L}$ de etanol $80 \%, 100 \mu \mathrm{L}$ de ninidrina $1 \%$ e $50 \mu \mathrm{L}$ de tampão citrato $0,02 \mathrm{M}(\mathrm{pH} 5,2)$ contendo $0,2 \%$ de ácido ascórbico (p/v). Em seguida, essas soluções foram inoculadas em microplacas, que foram então vedadas e incubadas em banho seco a temperatura de $80^{\circ} \mathrm{C}$ durante um período de 30 minutos. Após a reação colorimétrica, foi realizada a leitura da absorbância das amostras em leitor de microplacas Elisa a $570 \mathrm{~nm}$. Nessa etapa, todas as análises foram realizadas em triplicata e com base na curva padrão de leucina, com quantidades crescentes de 0; 5; $10 ; 20 ; 30 ; 40$ e 50 mol.

Por fim, para a dosagem de prolina, em $50 \mu \mathrm{L}$ de amostra foram acrescidos 100 $\mu \mathrm{L}$ de um mix composto por 0,4 g de ninidrina, $16 \mathrm{~mL}$ de etanol $50 \%$ e $24 \mathrm{~mL}$ de ácido acético glacial. Posteriormente, essas soluções foram distribuídas em microplacas, que foram então vedadas e incubadas em banho seco a temperatura de $80^{\circ} \mathrm{C}$ durante um período de 30 minutos. Após a reação colorimétrica, foi realizada a leitura da absorbância das amostras em leitor de microplacas Elisa a $520 \mathrm{~nm}$. Nessa fase, as respostas das triplicatas das amostras foram comparadas com padrões de prolina contendo $0 ; 2 ; 5 ; 10 ; 20 ; 30 ; 40$ e 50 $\mu \mathrm{mol}$.

\subsubsection{Proteínas totais}

Para a extração das proteínas totais foi colocado $10 \mathrm{mg}$ de massa seca das amostras em microtubos de $2 \mathrm{~mL}$ de capacidade, onde foi acrescentado $0,5 \mathrm{~mL}$ de $\mathrm{NaOH} 0,1 \mathrm{~N}$, sendo o material incubado a $4 \stackrel{\circ}{\circ}$ por 12 horas. Em seguida, foram 
adicionadas mais duas alíquotas de $0,25 \mathrm{~mL}$ de $\mathrm{NaOH} 0,1 \mathrm{~N}$, seguidas de mais uma hora de incubação a $4^{\circ} \mathrm{C}$ cada.

Após as incubações, as amostras foram centrifugadas a $12.000 \mathrm{rpm}$ por 10 minutos e o sobrenadante transferido para novos microtubos, onde foi adicionado às amostras $1 \mathrm{~mL}$ de ácido tricloroacético 20\%. Posteriormente, microtubos foram centrifugados a 13.000 rpm por 10 minutos para precipitação das proteínas e, em seguida, o sobrenadante foi descartado e as proteínas ressuspensas em $1 \mathrm{~mL}$ de $\mathrm{NaOH} 0,1 \mathrm{~N}$.

A quantificação foi realizada de acordo com o método descrito por Bradford (1956). Para tanto, foram pipetados $2 \mu \mathrm{L}$ das amostras em microplacas e foram adicionados $300 \mu \mathrm{L}$ de reagente Bradford 50\%. Após 5 minutos de repouso no escuro, foi realizada a leitura das absorbâncias em espectrofotômetro a $595 \mathrm{~nm}$. Todas as análises foram realizadas em triplicata e com base na curva padrão da albumina de soro bovino (BSA), com concentrações de 0,$0 ; 0,2 ; 0,4 ; 0,8 ; 1,2 ; 1,6 ; 2,0$ e $2,4 \mu \mathrm{g}$.

\subsubsection{Análise de perfil metabólico}

A extração foi realizada segundo a metodologia adaptada, descrita por Fiehn et al. (2000). Inicialmente, $10 \mathrm{mg}$ de massa seca das amostras (amostras liofilizadas e maceradas) foram colocadas em tubos de $2 \mathrm{~mL}$ de capacidade, sendo adicionado 1,4 $\mathrm{mL}$ de metanol e $60 \mu \mathrm{L}$ de solução de ribitol (utilizado como padrão interno) a 0,2 $\mathrm{mg} / \mathrm{mL}$. Cada amostra foi agitada em Vortex por 10 segundos e aquecida em banhoseco à $70 \stackrel{\circ}{\mathrm{C}}$ por 10 minutos, com agitação constante de $900 \mathrm{rpm}$. $\mathrm{O}$ material foi centrifugado a $12.000 \mathrm{rpm}$ por 10 minutos e $750 \mu \mathrm{L}$ do sobrenadante foi transferido para novos tubos. Ao sobrenadante foi então adicionado $375 \mu \mathrm{L}$ de clorofórmio a $4 \stackrel{\circ}{\circ} \mathrm{e}$ $750 \mu \mathrm{L}$ de água ultrapura a $4 \stackrel{\circ}{\mathrm{C}}$. Em seguida, o material foi agitado em Vortex por 10 segundos e centrifugado a $2.600 \mathrm{rpm}$ por 10 minutos para a separação das fases, sendo a fase superior obtida repassada para um novo tubo. Alíquotas de $200 \mu \mathrm{L}$ de cada amostra foram transferidas para novos tubos e foram secos em Speed Vac e armazenados em freezer $-80 \stackrel{\circ}{C}$ até utilização

Para a derivatização, as amostras foram secas em Speed Vac a $30{ }^{\circ} \mathrm{C}$ por 30 minutos, sendo adicionado $40 \mu \mathrm{L}$ de solução de cloridrato de metoxiamina (solução de $20 \mathrm{mg} / \mathrm{mL}$ em piridina). As amostras foram agitadas em Vortex por 10 segundos e 
aquecidas em banho-seco à $37^{\circ} \mathrm{C}$ por 2 horas, com agitação constante de $900 \mathrm{rpm}$. $\mathrm{O}$ material foi centrifugado então a $12.000 \mathrm{rpm}$ por 10 segundos e foi adicionado $70 \mu \mathrm{L}$ de $\mathrm{N}$-metil-N-trimetilsililtrifluoroacetamida (MSTFA) em cada tubo. As amostras foram agitadas em Vortex por 10 segundos e aquecidas em banho-seco à $37 \stackrel{\circ}{\circ} \mathrm{C}$ por 30 minutos, com agitação constante de $900 \mathrm{rpm}$. Em seguida, o material foi centrifugado a $12.000 \mathrm{rpm}$ por 10 segundos, sendo transferido $90 \mu \mathrm{L}$ das amostras para tubos de vidro inseridos em vials próprios para leitura em GC-MS.

A análise do perfil metabólico das amostras foi realizada por cromatografia gasosa com detecção por espectrometria de massa (GC-MS) com coluna HP-5MS (30 $\mathrm{m}, 0,25 \mathrm{~mm}$ de diâmetro e $0,25 \mu \mathrm{m}$ de espessura de filme), com injetor à $230{ }^{\circ} \mathrm{C}$ e temperatura do programa de $70 \stackrel{\circ}{\circ}$. Os parâmetros da espectrometria de massa foram: linha de transferência à $250^{\circ} \mathrm{C}$, quadrupolo à $150^{\circ} \mathrm{C}$, temperatura de detecção de 250 ${ }^{\circ} \mathrm{C}$, com modo de varredura solvente com passagem lenta. Como controle foi utilizada uma amostra composta de água ultrapura passada pelo processo de derivatização juntamente com as amostras. Todas as análises foram realizadas em triplicata e com base nas curvas padrões dos compostos observados nas amostras. 


\section{RESULTADOS E DISCUSSÃO}

\subsection{Açúcares solúveis}

Os resultados referentes aos teores de açúcares solúveis totais em razão do estádio de desenvolvimento embriogênico são apresentados na Figura 1. Observou-se que não foram verificadas diferenças significativas entre os segmentos foliares de dendezeiro que se mostraram responsivos ( $F L+C L$ ) ou não $(N R)$ ao processo de indução da embriogênese somática. Os índices de açúcares totais solúveis constatados foram próximos a $150 \mu \mathrm{g} \cdot \mathrm{mg}^{-1}$ de massa seca, valor estatisticamente superior aos $110 \mu \mathrm{g} \cdot \mathrm{mg}^{-1}$ de massa seca averiguados nos fragmentos de folhas imaturas utilizados como explantes iniciais (0 dias).

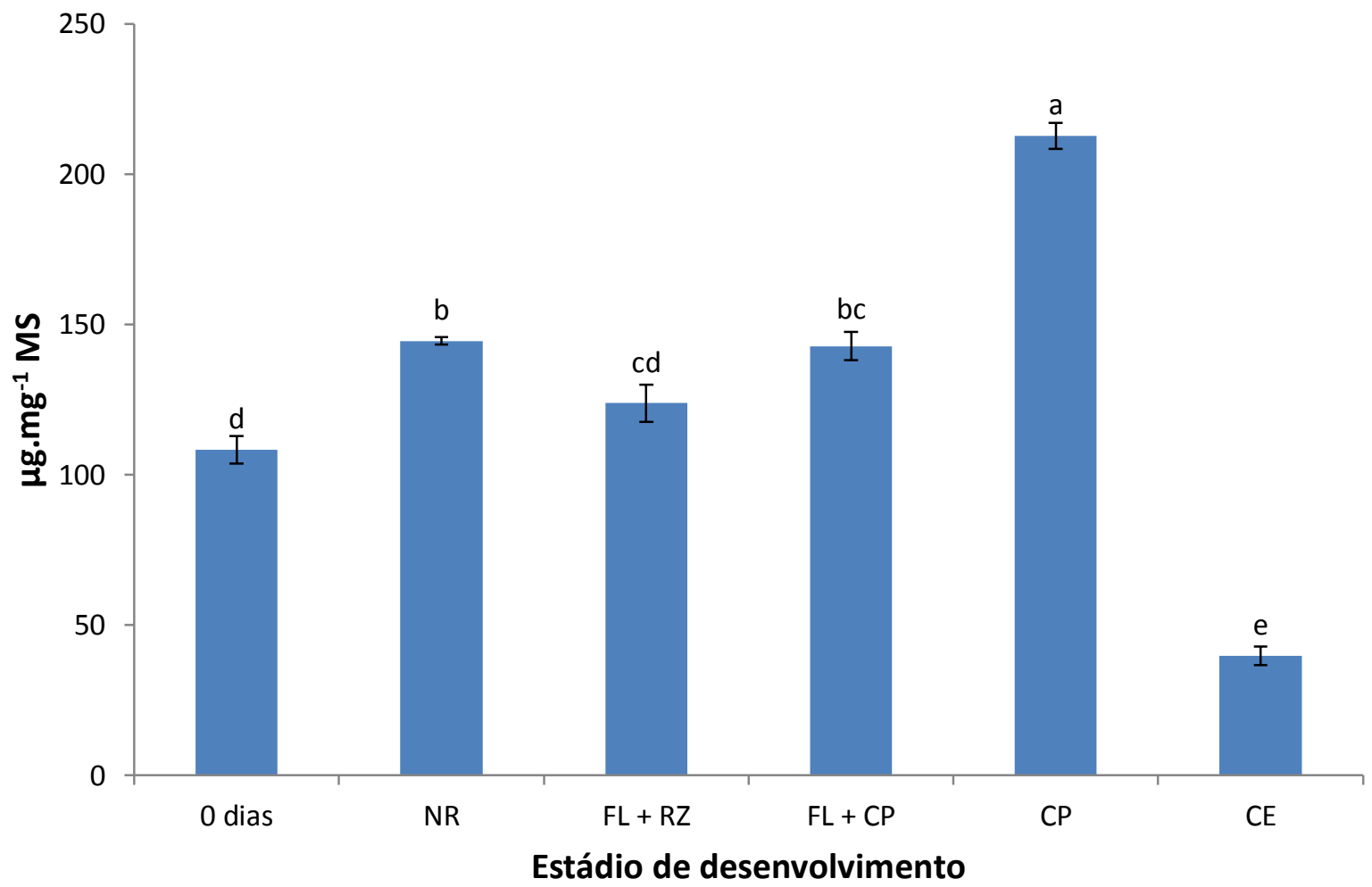

Figura 2. Teores de açúcares solúveis totais nos estádios de desenvolvimento obtidos durante a indução da embriogênese somática de folhas imaturas de plantas adultas dendezeiro (Elaeis guineensis Jacq.). Abreviações: $N R=$ folha que não reagiu; $F L+R Z$ = folha com raiz; $\mathrm{FL}+\mathrm{CP}=$ folha com calo primário; $\mathrm{CP}=$ calo primário; $\mathrm{CE}=$ calo embriogênico. Os dados representam as médias seguidas dos erros padrões. Médias 
seguidas pela mesma letra não diferem estatisticamente entre si pelo teste de Tukey a $5 \%$ de probabilidade.

Os resultados são distintos aos relatados por Gomes et al. (2014), que no estudo do perfil bioquímico dos estádios de aquisição e desenvolvimento da embriogênese somática de embriões zigóticos de Elaeis guineensis, constataram que durante o processo de indução, mais precisamente da inoculação dos explantes iniciais até a formação dos calos primários, os níveis de açúcares totais solúveis nos tecidos dos cultivos em desenvolvimento decaíram de aproximadamente 180 para cerca de 130 $\mu \mathrm{g} \cdot \mathrm{mg}^{-1}$ de massa seca.

Em contrapartida, quando se comparou a quantidade de açúcares solúveis totais presente nos diferentes tipos de calo, uma diferença considerável foi observada. Nos calos com menor competência para a formação de embriões somáticos, ou seja, nos calos primários, verificou-se teores de aproximadamente $220 \mu \mathrm{g}$ de açúcares totais solúveis por mg de massa seca, enquanto que nos calos embriogênicos os níveis destes compostos giraram em torno de $40 \mu \mathrm{g} \cdot \mathrm{mg}^{-1}$ de massa seca.

Tais resultados encontram-se de acordo com Baud et al. (2002) que afirmam que em tecidos embriogênicos em intenso processo de divisão celular, como em calos constituídos por grandes quantidades de células meristemáticas, o catabolismo dos açúcares totais é de fundamental importância, sendo responsável por suprir nestas culturas a intensa demanda de esqueletos carbônicos e energia metabólica.

Por outro lado, ao caracterizar bioquimicamente o processo de indução da embriogênese somática de Cordyline australis, Warchoł et al. (2015) não verificaram diferenças significativas nos teores de açúcares totais solúveis em calos com e sem competência embriogênica.

$\mathrm{Na}$ análise do conteúdo de açúcares totais em calos embriogênicos e não embriogênicos de Medicago arbórea, Martin et al. (2000) também averiguaram que, embora esses compostos representassem o principal componente da massa seca destes propágulos, cerca de $90 \%$, quando comparou-se os mesmos quase não se observou diferenças na concentração total destes metabólitos.

Contudo, nesse último trabalho verificou-se que existem importantes diferenças entre os massivos com e sem potencial embriogênico, quando os níveis de sacarose e 
de açúcares redutores, como a glicose e a frutose, foram examinados. Nele, constatouse que os maiores conteúdos de açúcares redutores foram obtidos a partir dos calos embriogênicos, enquanto que as concentrações mais elevadas de sacarose foram observadas nos calos não embriogênicos.

$\mathrm{Na}$ embriogênese somática de folhas imaturas de plantas adultas de Elaeis guineensis, alterações significativas nos níveis destes açúcares solúveis também foram averiguadas nos diferentes estádios do processo. Os resultados referentes aos teores de glicose, frutose e sacarose em razão do estádio de desenvolvimento embriogênico do dendezeiro são apresentados na Figura 3.

Nessa análise, verificou-se que, de forma geral, nos estádios de desenvolvimento desprovidos de calos, ou seja, nos explantes iniciais, nos segmentos foliares que não reagiram e nas folhas em processo de organogênese, os açúcares totais solúveis eram compostos por aproximadamente $40 \%$ de sacarose, $40 \%$ de frutose e $20 \%$ de glicose (Figura 4). Em contrapartida, observou-se nos cultivos relacionados com a calogênese (folhas com calos, calos primários e calos embriogênicos), que a sacarose foi o açúcar solúvel de maior relevância, com percentagens relativas variando entre 51 e $88 \%$ do total.

Ao estudar as mudanças nos níveis de carboidratos solúveis no decorrer da embriogênese somática e zigótica de Acca sellowiana, Pescador et al. (2008) também relataram a existência de diferenças significativas no perfil de sacarose, frutose e glicose ao examinar os diversos estádios que compunham estes processos. Nesse trabalho, pode-se verificar também uma coordenação do catabolismo e do anabolismo desses diferentes açúcares solúveis. Assim, de maneira geral, no período em que se observaram teores baixos de sacarose, verificaram-se concomitantemente concentrações elevadas de glucose e frutose, e quando aumentaram-se os índices de sacarose, ambas as hexoses mostraram-se com teores diminutos. 


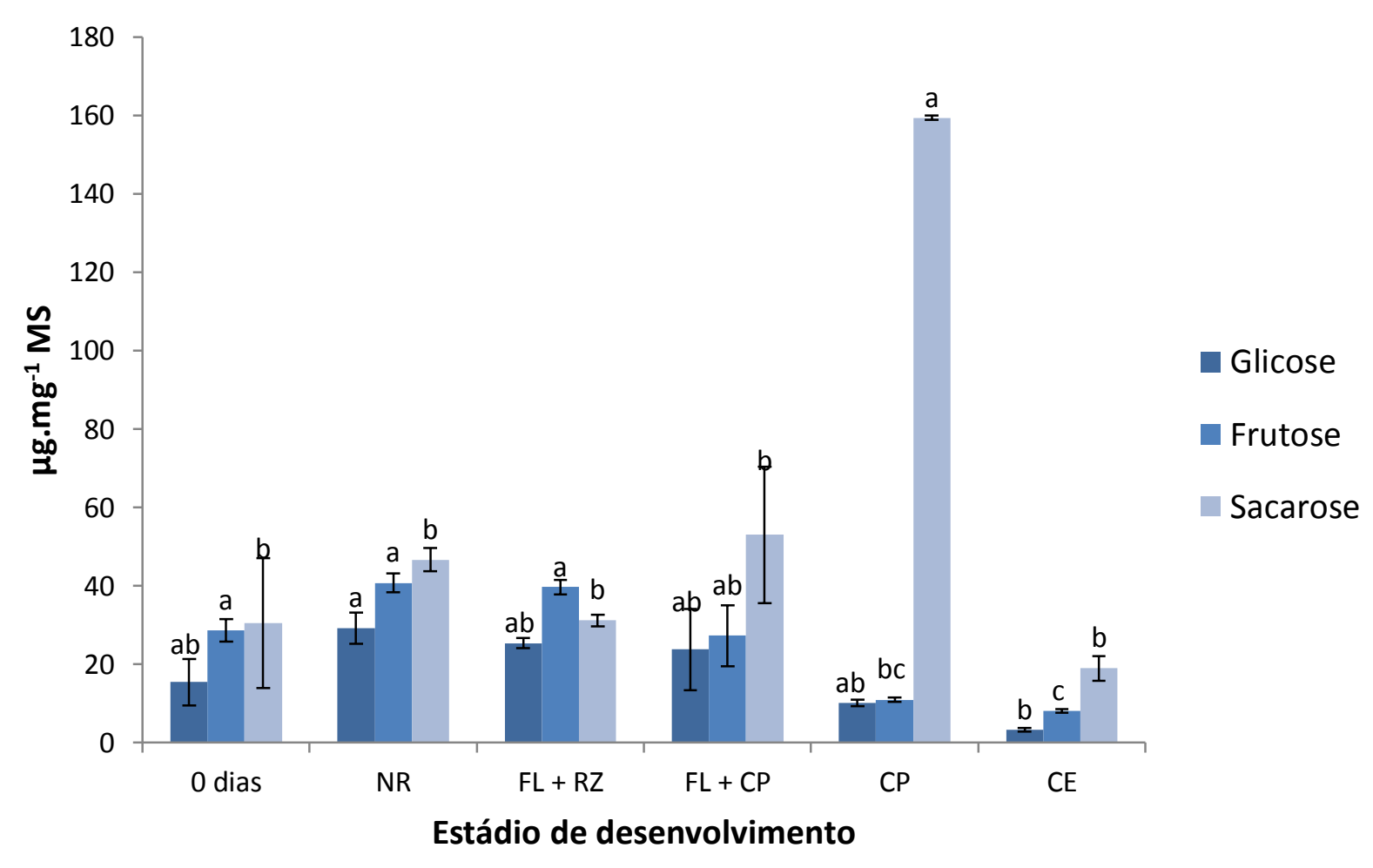

Figura 3. Teores de glicose, frutose e sacarose nos estádios de desenvolvimento obtidos durante a indução da embriogênese somática de folhas imaturas de plantas adultas dendezeiro (Elaeis guineensis Jacq.). Abreviações: $\mathrm{NR}=$ folha que não reagiu; $\mathrm{FL}+\mathrm{RZ}=$ folha com raiz; $\mathrm{FL}+\mathrm{CL}=$ folha com calo primário; $\mathrm{CP}=$ calo primário; $\mathrm{CE}=$ calo embriogênico. Os dados representam as médias seguidas dos erros padrões. Médias seguidas pela mesma letra não diferem estatisticamente entre si pelo teste de Tukey a 5\% de probabilidade na comparação dos índices de cada açúcar entre os diferentes estádios embriogênicos.

Tais resultados se devem, provavelmente, ao fato de que em algumas etapas do desenvolvimento embriogênico, o tipo de açúcar solúvel presente nos tecidos dos explantes e suas concentrações, poder ser, de forma geral, mais determinante que os próprios teores de açúcares totais solúveis, podendo atuar diretamente na regulação de fases específicas do processo (Iraqui \& Tremblay, 2001).

Nessa rota morfogênica, as hexoses glicose e frutose são de grande importância para a formação e diferenciação do calo, porque além de serem necessárias para a formação de polissacarídeos de reserva, como o amido, atuam ainda na biossíntese de polissacáridos estruturais da parede celular, como a celulose (Martin et al., 2000). 
Já o dissacarídeo sacarose, constituiu a principal fonte de esqueletos carbônicos e energia metabólica para as células dos explantes durante seu crescimento e desenvolvimento, representando assim, outro açúcar solúvel de elevada relevância para o processo de indução da competência embriogênica (Weber et al., 1997).

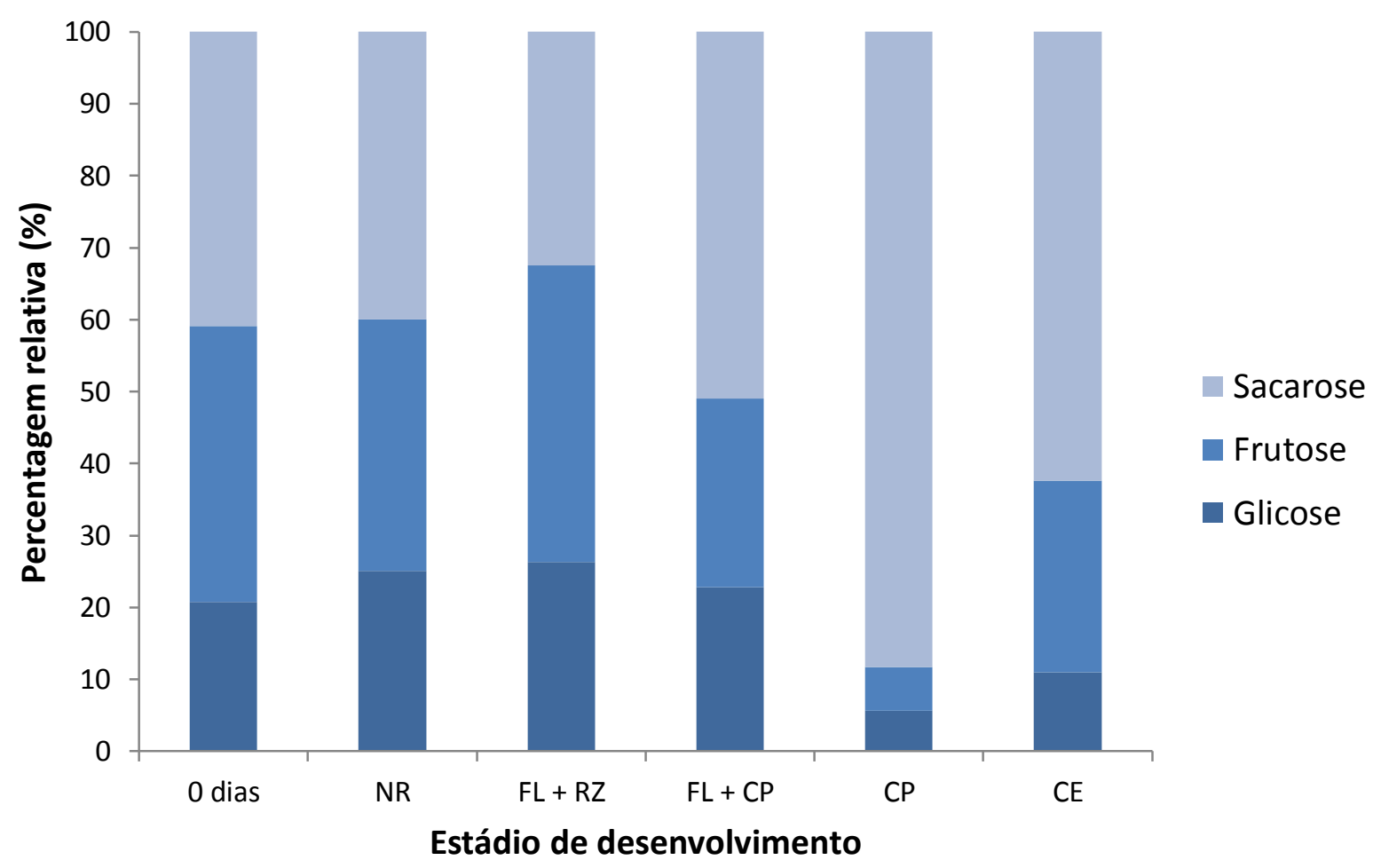

Figura 4. Abundâncias relativas de glicose, frutose e sacarose nos estádios de desenvolvimento obtidos durante a indução da embriogênese somática de folhas imaturas de plantas adultas de dendezeiro (Elaeis guineensis Jacq.). Abreviações: NR = folha que não reagiu; $F L+R Z=$ folha com raiz; $F L+C L=$ folha com calo primário; $\mathrm{CP}=$ calo primário; $\mathrm{CE}=$ calo embriogênico. Os dados representam as médias seguidas dos erros padrões.

\subsection{Amido}

No geral, verificou-se que as menores concentrações de amido foram detectadas nos explantes iniciais (0 dias) e naqueles que não se mostraram responsivos ao processo de indução (NR), que apresentaram em média de 5 a 7 $\mu \mathrm{g} \cdot \mathrm{mg}^{-1}$ de massa seca (Figura 5). 


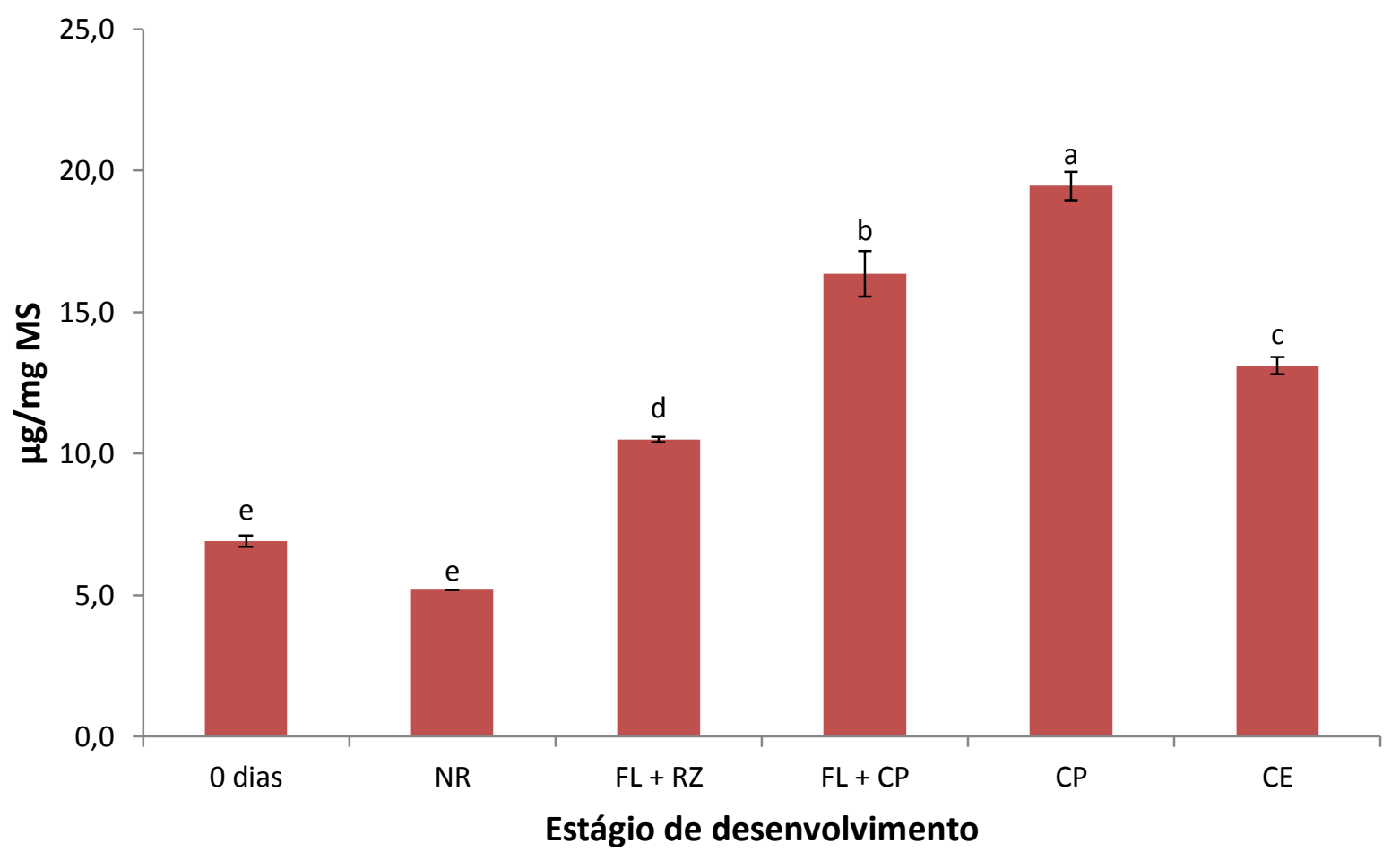

Figura 5. Teores de amido nos estádios de desenvolvimento obtidos durante a indução da embriogênese somática de folhas imaturas de plantas adultas de dendezeiro (Elaeis guineensis Jacq.). Abreviações: $N R=$ folha que não reagiu; $F L+R Z=$ folha com raiz; $\mathrm{FL}+\mathrm{CL}=$ folha com calo primário; $\mathrm{CP}=$ calo primário; $\mathrm{CE}=$ calo embriogênico. $\mathrm{Os}$ dados representam as médias seguidas dos erros padrões. Médias seguidas pela mesma letra não diferem estatisticamente entre si pelo teste de Tukey a $5 \%$ de probabilidade.

Gomes et al. (2014), ao comparar o perfil bioquímico durante os estágios de aquisição e desenvolvimento da embriogênese somática de Elaeis guineensis, também relataram que nos tecidos dos embriões zigóticos utilizados como explantes iniciais do processo de indução, a quantidade de amido como composto de reserva também foi a que apresentou as menores médias, cerca de $0,5 \%$ de hidrólise. Para os autores, esse resultado se deve ao fato do acúmulo de material de reserva nesses explantes ser realizado principalmente por meio de lipídios, hipótese que também pode ser utilizada para explicar os resultados obtidos no presente trabalho.

Por outro lado, nos segmentos foliares responsivos a organogênese $(F L+R Z)$ e a calogênese $(F L+C L)$, constatou-se que os níveis deste composto apresentaram uma 
elevação significativa. Nestes estádios de desenvolvimento, respectivamente, concentrações de amido de 10,5 e 16,4 $\mu \mathrm{g} \cdot \mathrm{mg}^{-1}$ de massa seca foram observadas.

Os resultados são semelhantes aos descritos por Pescador et al. (2008), ao avaliar o metabolismo dos açúcares solúveis e do amido no transcorrer da embriogênese zigótica de Acca sellowiana, onde foi reportado um aumento considerável nos teores de amido durante os estádios embriogênicos subsequentes ao processo de polinização. Este fato, no entanto, não foi constatado por CangahualaInocente et al. (2014) no estudo da dinâmica das mudanças fisiológicas e bioquímicas que ocorrem durante a embriogênese somática da goiabeira-serrana, onde observouse que as quantidades de amido presentes no corpo dos propágulos em estádios iniciais de desenvolvimento decaíram de maneira expressiva. Estas diferenças, segundo os autores, demonstram que no começo do processo embriogênico, esse polissacarídeo de reserva pode apresentar diferentes atribuições.

Em dendezeiro, no princípio do processo de formação de calos o metabolismo do amido, além de ser responsável pelo fornecimento de energia metabólica para as células em divisão e diferenciação, também está diretamente relacionado com a manutenção do potencial osmótico favorável ao desenvolvimento dos cultivos (Gomes et al., 2014).

Por fim, em relação aos diferentes tipos de massivos celulares obtidos constatou-se que os calos primários foram os propágulos que apresentam as maiores concentrações de amido, em média 19,5 $\mu \mathrm{g} \cdot \mathrm{mg}^{-1}$ de massa seca, valor estatisticamente superior ao examinado nos calos embriogênicos, que apresentam em média 13,1 $\mu \mathrm{g} \cdot \mathrm{mg}^{-1}$ de massa seca.

Ao analisar as diferenças no conteúdo de amido em calos embriogênicos e não embriogênicos de Medicago arborea, Martin et al. (2000) também revelaram que, embora esse polissacarídeo tenha desempenhado um papel crucial na formação de ambos os tipos de calo, no desenvolvimento embriogênico dessa espécie os níveis mais elevados de amido também foram observados nas massas de células com características não embriogênicas. Para os autores, tais resultados se devem ao fato da indução da competência embriogênica ser um processo que requer uma quantidade considerável de energia, que segundo os mesmos é fornecida principalmente por meio da degradação do amido, onde são gerados intermediários glicolíticos utilizados então para a produção de grandes quantidades de ATP (trifosfato de adenosina). 


\section{3. Ácidos graxos (ésteres metílicos de ácidos graxos)}

Os resultados referentes aos teores de ácidos graxos totais em razão do estádio de desenvolvimento embriogênico são apresentados na Figura 6. Verificou-se que ao final da etapa de indução, independentemente do fato dos segmentos foliares terem originados calos $(F L+C L)$, raízes $(F L+R Z)$ ou não terem reagidos $(N R)$, os mesmos não apresentaram entre si diferenças significativas quanto aos seus níveis de ácidos graxos totais que, em média, apresentaram valores pouco abaixo de $50 \mu \mathrm{g} \cdot \mathrm{mg}^{-1}$ de massa seca, concentrações estatisticamente inferiores a observada nos explantes iniciais (0 dias) que apresentaram cerca de $100 \mu \mathrm{g} \cdot \mathrm{mg}^{-1}$ de massa seca.

Os resultados são distintos aos relatados por Cunha \& Fernandes-Ferreira (2003) na avaliação das variações ontogênicas das taxas de ácidos graxos livres e esterificados, durante a embriogênese somática de Linum usitatissimum, onde observou-se que ao longo do processo de indução os níveis destes compostos aumentaram de maneira progressiva com a desdiferenciação dos explantes e com o desenvolvimento dos estádios iniciais do calo.

Já em relação aos diferentes tipos de calos, constatou-se que nos propágulos com maior potencial morfogênico, ou seja, nos calos embriogênicos os níveis de ácidos graxos totais estavam acima dos $300 \mu \mathrm{g} \cdot \mathrm{mg}^{-1}$ de massa seca. Em contrapartida, observou-se que nos calos primários os índices destes metabólitos foram em média de apenas $72,6 \mu \mathrm{g} \cdot \mathrm{mg}^{-1}$ de massa seca. 


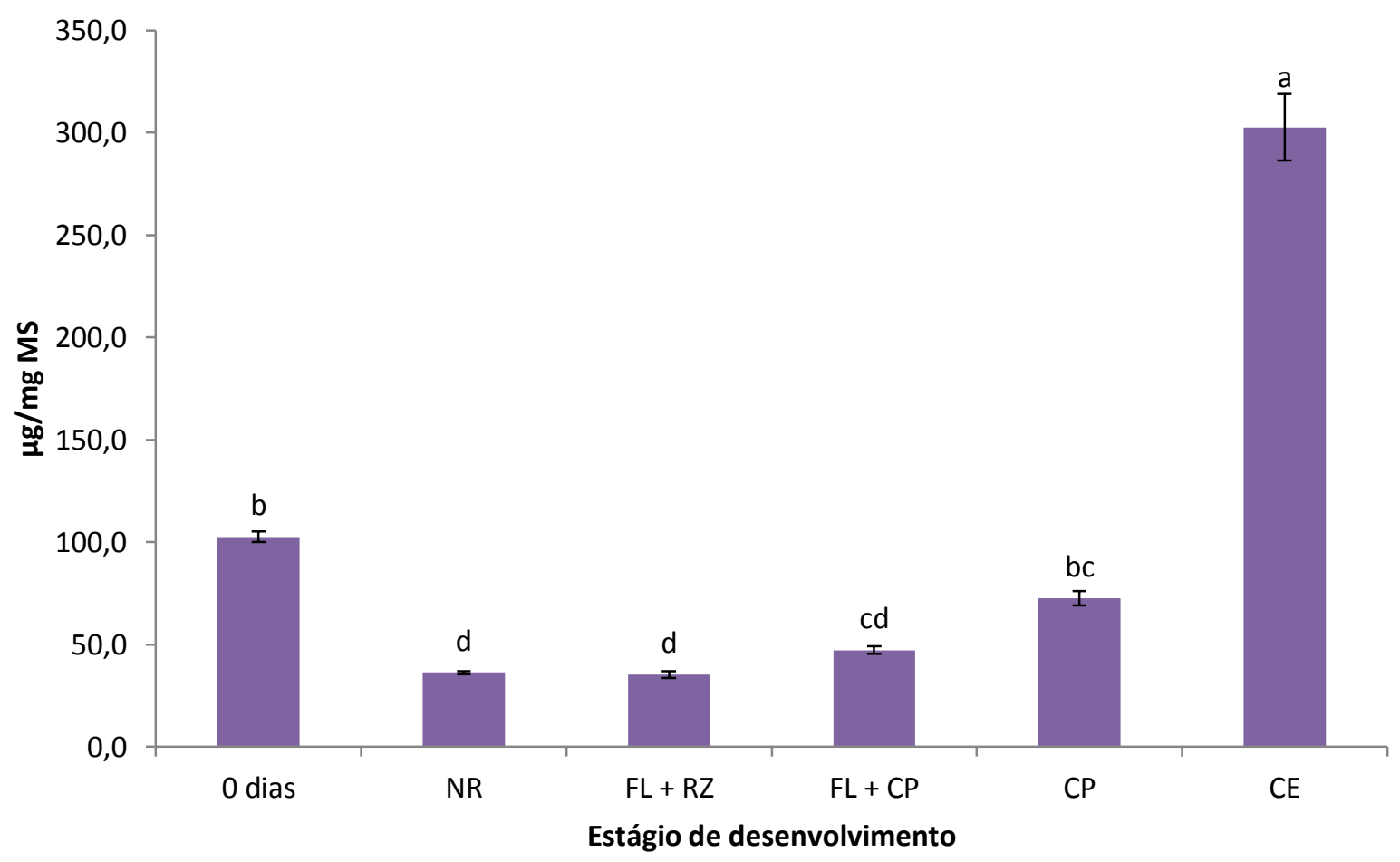

Figura 6. Teores de ácidos graxos totais nos estádios de desenvolvimento obtidos durante a indução da embriogênese somática de folhas imaturas de plantas adultas dendezeiro (Elaeis guineensis Jacq.). Abreviações: $N R=$ folha que não reagiu; $F L+R Z$ = folha com raiz; $\mathrm{FL}+\mathrm{CL}=$ folha com calo primário; $\mathrm{CP}=$ calo primário; $\mathrm{CE}=$ calo embriogênico. Os dados representam as médias seguidas dos erros padrões. Médias seguidas pela mesma letra não diferem estatisticamente entre si pelo teste de Tukey a $5 \%$ de probabilidade.

No estudo da composição dos lipídios e ácidos graxos que constituem os calos embriogênicos e não embriogênicos de Prunus avium, Reidiboym-Talleux \& March (1999) também reportaram que nessa espécie os massivos embriogênicos também mostraram maiores concentrações de ácidos graxos totais que as massas celulares não embriogênicas. Nesse estudo, constatou-se ainda que as células com competência embriogênica exibiram plastídios e retículos endoplasmáticos associados com corpos lipídicos, enquanto que as células dos calos não embriogênicos foram caracterizadas por apresentar falta de corpos lipídicos citoplasmáticos.

Tais resultados corroboram Turnham \& Northcote (1984), que ao estudar a embriogênese somática de Elaeis guineensis, revelaram que gotas de lipídios estavam 
sendo acumuladas no interior das células embriogênicas em processo de formação de embriões globulares, mas estavam ausentes no corpo das células que compunham os calos indiferenciados.

Assim, demonstra-se que durante a etapa de indução da embriogênese somática de folhas imaturas de dendezeiro, também foi verificada uma grande participação dos ácidos graxos totais na dinâmica do acúmulo e conversão das reservas energéticas presentes nos tecidos dos propágulos em desenvolvimento (Figura 7).

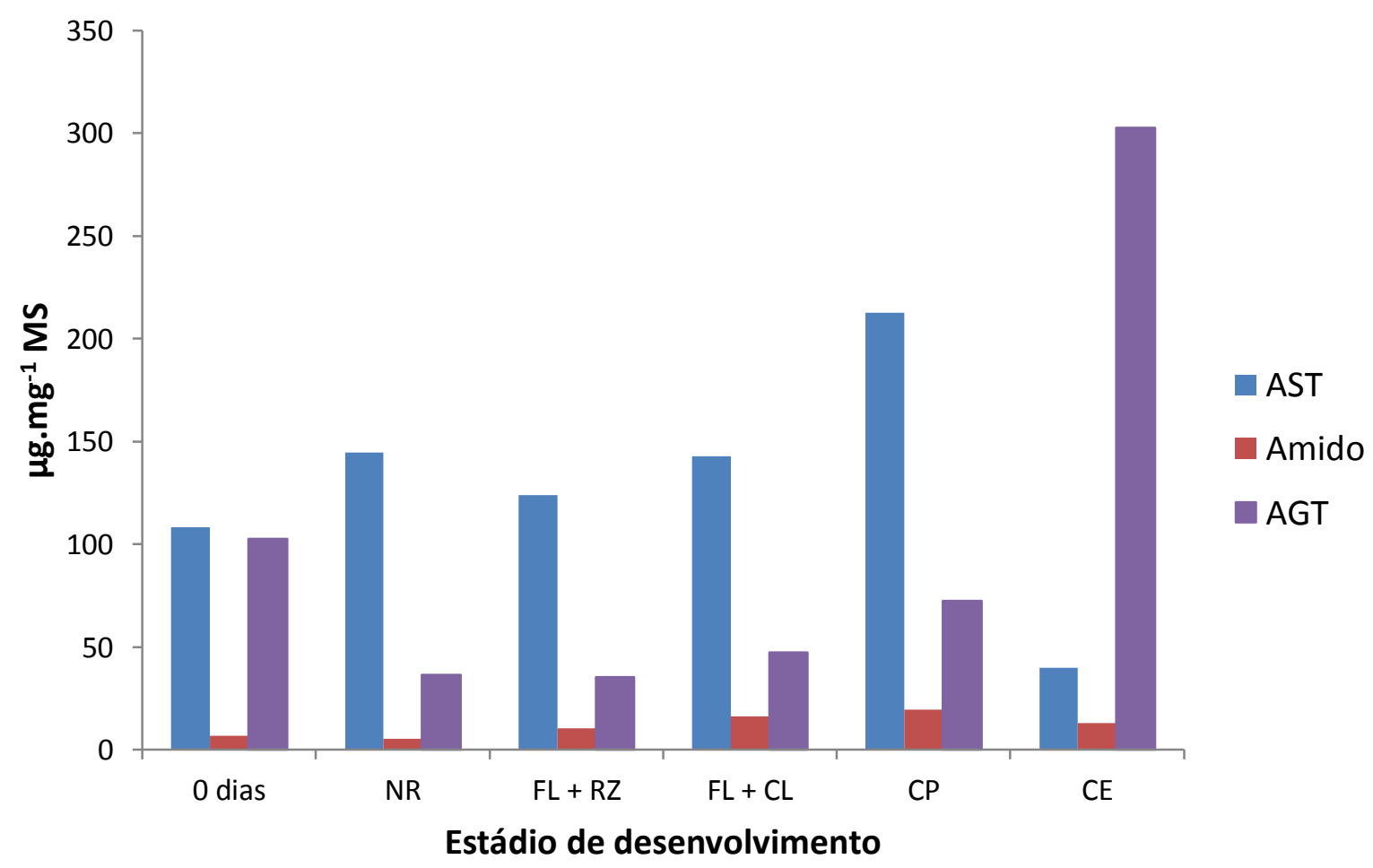

Figura 7. Teores de açúcares solúveis totais (AST), amido e ácidos graxos totais (AGT) nos estádios de desenvolvimento obtidos durante a indução da embriogênese somática de folhas imaturas de plantas adultas dendezeiro (Elaeis guineensis Jacq.). Abreviações: $N R=$ folha que não reagiu; $F L+R Z=$ folha com raiz; $F L+C L=$ folha com calo primário; $\mathrm{CP}=$ calo primário; $\mathrm{CE}=$ calo embriogênico. 
Em relação aos teores dos ácidos graxos que constituem os compostos lipídicos nos estádios de desenvolvimento obtidos durante a indução da embriogênese somática de folhas imaturas de dendezeiro, os resultados são apresentados na Tabela 1.

Nesta etapa do desenvolvimento embriogênico, verificou-se que os lipídios presentes nos explantes em cultivo são constituídos pelos respectivos ácidos graxos: ácido mirístico (C14:0), ácido pentadecílico (C15:0), ácido palmítico (C16:0), ácido esteárico (C18:0), ácido oléico (C18:1), ácido linoléico (C18:2), ácido linolênico (C18:3), ácido araquídico (C20:0), ácido gadoléico (C20:1), ácido behênico (C22:0) e ácido erúcico (C22:1).

Tabela 1. Teores dos ácidos graxos que constituem os lipídios nos estádios de desenvolvimento obtidos durante a indução da embriogênese somática de folhas imaturas de plantas adultas dendezeiro (Elaeis guineensis Jacq.)

\begin{tabular}{|c|c|c|c|c|c|c|}
\hline \multirow{2}{*}{$\begin{array}{l}\text { Ácido graxo } \\
(\mu \mathrm{g} / \mathrm{mg} \mathrm{MS})\end{array}$} & \multicolumn{6}{|c|}{ Estágio de desenvolvimento } \\
\hline & 0 dias & $\mathrm{N}$ reagiu & $\mathrm{FL}+\mathrm{RZ}$ & $F L+C P$ & $\mathrm{CP}$ & CE \\
\hline C14:0 & $2,0 \pm 0,0 \mathrm{~A}$ & $2,0 \pm 0,0 \mathrm{~A}$ & $0,0 \pm 0,0 \mathrm{~B}$ & $0,0 \pm 0,0 \mathrm{~B}$ & $2,0 \pm 0,0 \mathrm{~A}$ & $2,0 \pm 0,0 \mathrm{~A}$ \\
\hline C15:0 & $0,0 \pm 0,0 \mathrm{~A}$ & $0,0 \pm 0,0 \mathrm{~A}$ & $0,0 \pm 0,0 \mathrm{~A}$ & $0,0 \pm 0,0 \mathrm{~A}$ & $0,6 \pm 0,6 \mathrm{~A}$ & $1,3 \pm 0,6 \mathrm{~A}$ \\
\hline C16:0 & $55,3 \pm 1,3 \mathrm{~B}$ & $16,6 \pm 0,6 \mathrm{D}$ & $14,6 \pm 0,6 \mathrm{D}$ & $19,3 \pm 0,6 \mathrm{CD}$ & $30,0 \pm 1,1 \mathrm{C}$ & $93,3 \pm 5,6 \mathrm{~A}$ \\
\hline C18:0 & $6,0 \pm 0,0 \mathrm{~B}$ & $4,0 \pm 0,0 \mathrm{C}$ & $2,0 \pm 0,0 \mathrm{D}$ & $2,0 \pm 0,0 \mathrm{D}$ & $2,6 \pm 0,6 \mathrm{CD}$ & $15,3 \pm 0,6 \mathrm{~A}$ \\
\hline C18:1 & $4,0 \pm 0,0 \mathrm{~B}$ & $0,0 \pm 0,0 \mathrm{D}$ & $0,0 \pm 0,0 \mathrm{D}$ & $0,0 \pm 0,0 \mathrm{D}$ & $2,0 \pm 0,0 \mathrm{C}$ & $6,6 \pm 0,6 \mathrm{~A}$ \\
\hline C18:1-2 & $0,0 \pm 0,0 \mathrm{~B}$ & $0,0 \pm 0,0 \mathrm{~B}$ & $0,0 \pm 0,0 \mathrm{~B}$ & $0,0 \pm 0,0 \mathrm{~B}$ & $0,0 \pm 0,0 \mathrm{~B}$ & $2,0 \pm 0,0 \mathrm{~A}$ \\
\hline C18:2 & $28,0 \pm 1,1 \mathrm{~B}$ & $6,0 \pm 0,0 \mathrm{C}$ & $12,6 \pm 0,6 \mathrm{BC}$ & $17,3 \pm 0,6 \mathrm{BC}$ & $27,3 \pm 0,6 \mathrm{~B}$ & $163,3 \pm 8,6 \mathrm{~A}$ \\
\hline C18:3 & $4,0 \pm 0,0 \mathrm{~B}$ & $4,0 \pm 0,0 \mathrm{~B}$ & $3,3 \pm 0,6 \mathrm{~B}$ & $4,0 \pm 0,0 \mathrm{~B}$ & $7,3 \pm 0,6 \mathrm{~A}$ & $6,6 \pm 0,6 \mathrm{~A}$ \\
\hline C20:0 & $0,0 \pm 0,0 \mathrm{~B}$ & $0,0 \pm 0,0 \mathrm{~B}$ & $0,0 \pm 0,0 \mathrm{~B}$ & $0,0 \pm 0,0 \mathrm{~B}$ & $0,6 \pm 0,6 \mathrm{~B}$ & $4,0 \pm 0,0 \mathrm{~A}$ \\
\hline C20:1 & $1,3 \pm 0,6 \mathrm{~A}$ & $0,0 \pm 0,0 \mathrm{~A}$ & $0,0 \pm 0,0 \mathrm{~A}$ & $0,0 \pm 0,0 \mathrm{~A}$ & $0,0 \pm 0,0 \mathrm{~A}$ & $1,3 \pm 0,6 \mathrm{~A}$ \\
\hline C22:0 & $2,0 \pm 0,0 \mathrm{~B}$ & $2,0 \pm 0,0 \mathrm{~B}$ & $2,0 \pm 0,0 \mathrm{~B}$ & $2,0 \pm 0,0 \mathrm{~B}$ & $0,0 \pm 0,0 \mathrm{C}$ & $4,0 \pm 0,0 \mathrm{~A}$ \\
\hline C22:1 & $0,0 \pm 0,0 \mathrm{~B}$ & $1,6 \pm 0,3 \mathrm{AB}$ & $0,6 \pm 0,6 \mathrm{AB}$ & $0,6 \pm 0,6 \mathrm{AB}$ & $0,0 \pm 0,0$ & $2,0 \pm 0,0 \mathrm{~A}$ \\
\hline
\end{tabular}

Abreviações: $\mathrm{NR}=$ não reagiu; $\mathrm{FL}+\mathrm{RZ}=$ folha com raiz; $\mathrm{FL}+\mathrm{CL}=$ folha com calo primário; $\mathrm{CP}=$ calo primário; $\mathrm{CE}=$ calo embriogênico; $\mathrm{C} 14: 0=$ mirístico; $\mathrm{C} 15: 0=$ pentadecílico; $C 16: 0=$ palmítico; $C 18: 0=$ esteárico; $C 18: 1=$ oléico; $C 18: 1^{(2)}=$ não identificado; $\mathrm{C} 18: 2$ = linoléico; $\mathrm{C} 18: 3=$ linolênico; $\mathrm{C} 20: 0=$ araquídico; $\mathrm{C} 20: 1=$ gadoléico; $\mathrm{C} 22: 0$ = behênico; C22:1 = erúcico. Os dados representam as médias seguidas dos erros padrões. Médias seguidas pela mesma letra não diferem estatisticamente entre si pelo teste de Tukey a $5 \%$ de probabilidade na comparação 
dos índices de cada ácido graxo entre os diferentes estádios embriogênicos. "Valor abaixo do limite mínimo de detecção.

Entretanto, constatou-se que, de forma geral, os lipídios que compõem o corpo dos cultivos em desenvolvimento são compostos em sua maior parte pelo ácido palmítico e pelo ácido linoléico, que juntos possuem uma abundância relativa média de aproximadamente $80 \%$ (Figura 8 ).

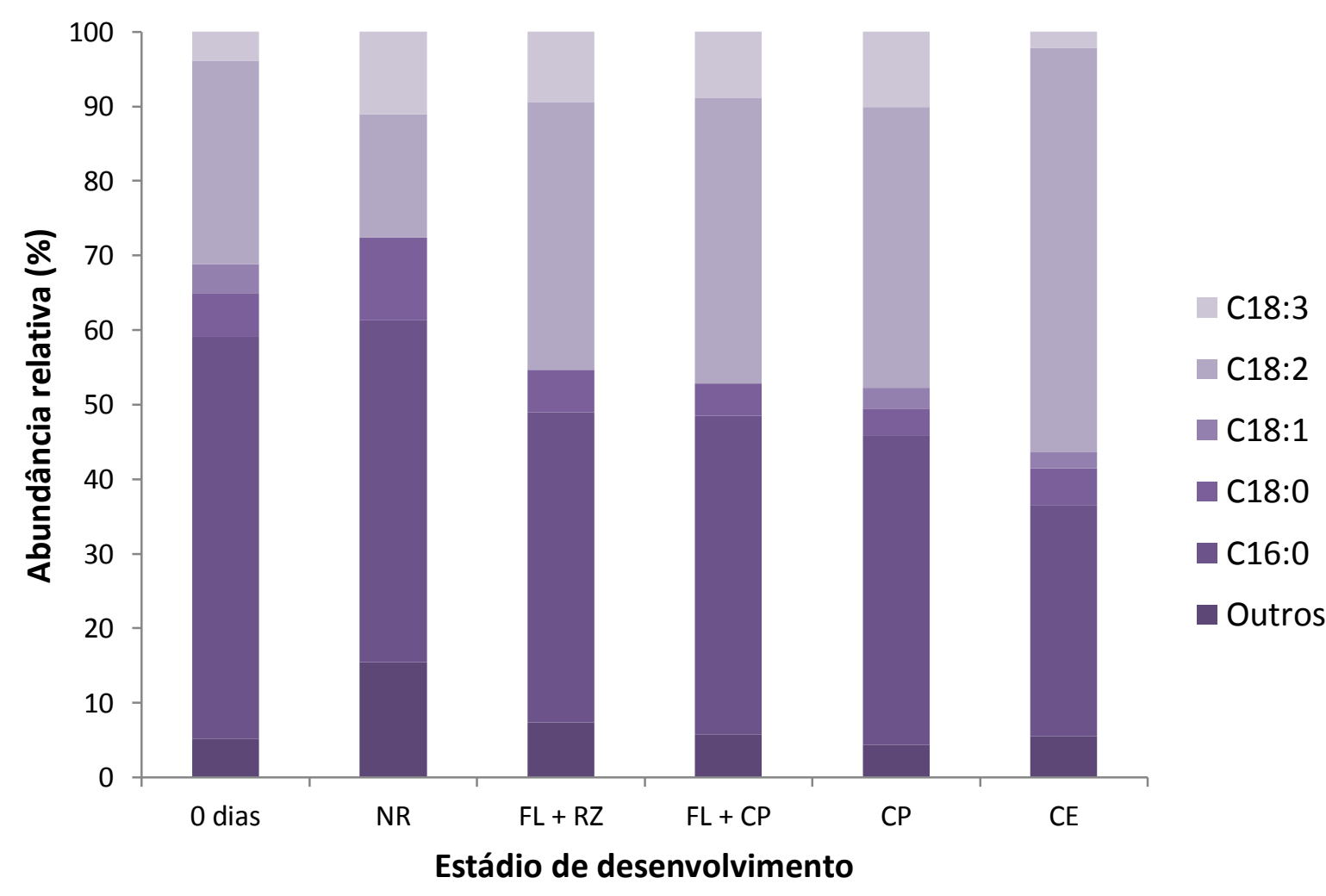

Figura 8. Abundâncias relativas dos ácidos graxos de maior relevância na constituição dos lipídios nos estádios de desenvolvimento obtidos durante a indução da embriogênese somática de folhas imaturas de plantas adultas dendezeiro (Elaeis guineensis Jacq.). Abreviações: $N R=$ folha que não reagiu; $F L+R Z=$ folha com raiz; $\mathrm{FL}+\mathrm{CL}=$ folha com calo primário; $\mathrm{CP}=$ calo primário; $\mathrm{CE}=$ calo embriogênico; $\mathrm{C} 16: 0$ = palmítico; $C 18: 0$ = esteárico; $C 18: 1$ = oléico; $C 18: 2$ = linoléico; $C 18: 3$ = linolênico .

Os resultados são semelhantes aos descritos por Grigová et al. (2007), ao analisar a dinâmica dos lipídios de armazenamento na embriogênese somática de 
Picea abies, onde constatou-se também que o ácido palmítico e o ácido linoléico representavam dois dos três ácidos graxos mais abundantes nas células dos cultivos em desenvolvimento.

Tais resultados encontram-se de acordo com Dussert et al. (2013), no estudo das diferenças no conteúdo de óleo e na composição dos ácidos graxos durante o transcorrer da embriogênese zigótica de Elaeis guineensis, no qual também foi verificado que o ácido palmítico e o ácido linoléico, juntamente com o ácido oléico foram os ácidos graxos que apresentaram os níveis mais elevados. Nesse trabalho, relatou-se ainda que poucas mudanças no perfil dos ácidos graxos foram observadas durante o desenvolvimento dos embriões zigóticos da espécie. Nele, as mudanças mais significativas foram uma diminuição do conteúdo de C18:2 (ácido linoléico) de 29 para $21 \%$ e um aumento na percentagem de C18:1 (ácido oléico) de 29 para 37\%.

No presente trabalho alterações no padrão destes ácidos graxos também foram observadas quando se comparou os diferentes estádios de desenvolvimento. No mesmo, constatou-se que ao final do processo de indução, independentemente dos segmentos foliares terem gerados calos $(F L+C L)$ ou raízes $(F L+R Z)$, estes apresentaram cerca de $42 \%$ de ácido palmítico e aproximadamente $37 \%$ de ácido linoléico. Já os explantes iniciais (0 dias) e os tecidos foliares que não responderam (NR), na média, apresentaram 50\% de ácido palmítico e 22\% de ácido linoléico.

Aly et al. (2008) ao avaliarem o perfil dos ácidos graxos na embriogênese somática de folhas de Simmondsia chinensis, embora tenham relatado uma influencia substancial na composição lipídica das culturas com a suplementação dos meios nutritivos com reguladores de crescimento, praticamente não visualizaram no corpo dos propágulos examinados diferenças nos níveis de ácido palmítico e ácido linoléico, que em média ficaram em torno de 32 e $13 \%$, respectivamente.

Por fim, quanto ao perfil dos ácidos graxos nos diferentes estádios de desenvolvimento do calo, observou-se que nos calos primários, o ácido palmítico, assim como verificado nos cultivos mencionados anteriormente, representa o ácido graxo com maior abundância relativa $(41,4 \%)$. Em contrapartida, nos calos embriogênicos constatou-se que o ácido linoléico, com uma abundância relativa superior a $50 \%$, constitui o ácido graxo de maior presença. 
Nas mudanças na composição lipídica durante a embriogênese somática em folhas de Cichorium, Blanckaert et al. (2000) também relataram uma semelhança na composição dos ácidos graxos em cultivos não embriogênicos e em culturas que apresentaram competência embriogênica. Além disso, assim como verificado no presente experimento, nas análises também se verificou que os propágulos embriogênicos apresentaram uma significativa redução na abundância relativa de C18:3 (ácido linolênico), concomitantemente com a elevação das taxas de C18:2 (ácido linoléico), que nestes tecidos passaram então a representar o ácido graxo mais expressivo. Ademais, em explantes não embriogênicos a diminuição do ácido linolênico também foi consideravelmente inferior, com os percentuais de ácido linoléico e ácido linolênico bastante semelhantes entre si.

Pescador et al. (2012) ao comparar o perfil dos ácidos graxos presentes no corpo de calos embriogênicos e não embriogênicos de Acca sellowiana também demonstraram resultados semelhantes. Nessa espécie, observou-se nos massivos celulares que originaram os embriões somáticos, teores de ácido linoléico girando em torno de $64 \%$, mesma abundância relativa encontrada nos embriões zigóticos. Em contrapartida, nas massas de células não embriogênicas os percentuais deste composto foi de apenas $17 \%$. Assim, para esses autores a elevada concentração de C18:2 constitui uma importante característica do processo embriogênico.

Para Reidiboym-Talleux \& March (1999), este fato está associado a maior atividade metabólica das células meristemáticas que formam praticamente toda a estrutura dos calos embriogênicos, pois o aumento do metabolismo celular auxilia a biossíntese de ácidos graxos insaturados de cadeias longas, como por exemplo, o ácido linoléico.

\subsection{Aminoácidos livres}

Verificou-se que nas folhas utilizadas como explantes iniciais ( 0 dias) e naquelas onde a presença de massivos celulares (calos) foram constatados ( $F L+C L$ ), os níveis de aminoácidos totais livres não diferiram estatisticamente entre si, apresentando em média $1220 \mathrm{nmol} . \mathrm{mg}^{-1}$ de massa seca (Figura 9). Estes resultados são significativamente superiores aos observados nos fragmentos de folhas que não responderam a calogênese, ou seja, nos tecidos foliares que não reagiram (NR) e 
naqueles em processo de organogênese $(F L+R Z)$ que, em média, giraram em torno de 625 nmol. $\mathrm{mg}^{-1}$ de massa seca.

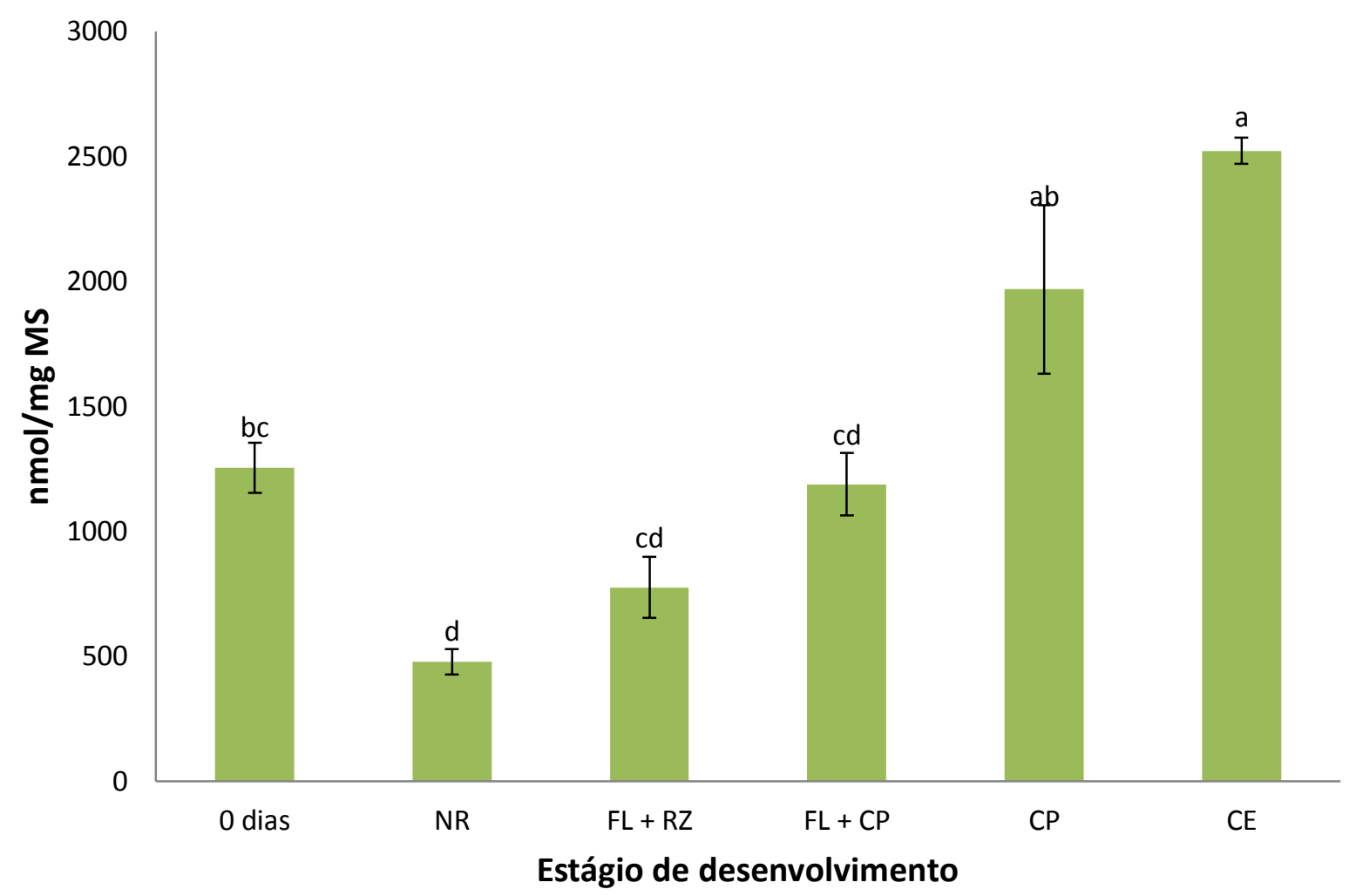

Figura 9. Teores de aminoácidos totais livres nos estádios de desenvolvimento obtidos durante a indução da embriogênese somática de folhas imaturas de plantas adultas dendezeiro (Elaeis guineensis Jacq.). Abreviações: $N R=$ folha que não reagiu; $F L+R Z$ = folha com raiz; $\mathrm{FL}+\mathrm{CL}=$ folha com calo primário; $\mathrm{CP}=$ calo primário; $\mathrm{CE}$ = calo embriogênico. Os dados representam as médias seguidas dos erros padrões. Médias seguidas pela mesma letra não diferem estatisticamente entre si pelo teste de ScottTukey a $5 \%$ de probabilidade.

$\mathrm{Na}$ comparação do perfil bioquímico dos estádios de aquisição e desenvolvimento da embriogênese somática de embriões zigóticos de dendezeiro, Gomes et al. (2014) também relataram nos estádios iniciais da calogênese que as concentrações dos aminoácidos totais livres presentes nos cultivos também não apresentaram variações expressivas, ficando nesse caso com valores um pouco superior a $300 \mathrm{nmol} . \mathrm{mg}^{-1}$ de massa seca. Ademais, nesse trabalho verificou-se ainda 
que a treonina, a glicina, a asparagina, a arginina, a leucina e a glutamina constituem os aminoácidos livres mais abundantes desta fase.

Ao avaliar a dinâmica das alterações bioquímicas no transcorrer da embriogênese somática de Acca sellowiana, Cangahuala-Inocente et al. (2014) também citaram a arginina, asparagina e glutamina como sendo três dos aminoácidos livres de maior presença no corpo dos propágulos durante a etapa de indução do desenvolvimento embriogênico. Entretanto, averiguou-se nesse trabalho que, nesta fase do processo, os teores dos aminoácidos totais livres aumentam rapidamente quando os explantes iniciais começaram a entumecer e, em seguida, decairam consideravelmente com o início da proliferação das células epidérmicas destas culturas.

Em se tratando dos diferentes tipos de calo, assim como verificado nos ácidos graxos totais, constatou-se que os calos primários foram os cultivos que apresentaram as menores concentrações de aminoácidos totais livres, em média cerca de 2.000 nmol. $\mathrm{mg}^{-1}$ de massa seca. Esse valor difere estatisticamente dos $2.500 \mathrm{nmol} . \mathrm{mg}^{-1} \mathrm{de}$ massa seca observados nas massas de células embriogênicas (CE).

Kumar \& Kumari (2011), ao estudar os fatores que afetam a embriogênese somática em Carthamus tinctorius em nível morfológico e bioquímico, não observaram diferenças significativas nos valores dos aminoácidos totais livres encontrados em calos de aspecto friável e de crescimento rápido e em calos compactos de crescimento lento.

No entanto, os resultados obtidos no presente trabalho corroboram Ortiz-Lopez et al. (2000) que afirmam que os aminoácidos livres, além de serem a principal forma de transporte de nitrogênio nas células das plantas, são também muito utilizados para a síntese de proteínas. Esse fato permite o crescimento e o desenvolvimento dos tecidos vegetais com elevada atividade metabólica, como os dos calos embriogênicos que são compostos por uma grande quantidade de células meristemáticas em intenso processo de divisão celular.

Quanto aos teores de prolina em razão do estádio de desenvolvimento embriogênico, os resultados são apresentados na Figura 10. Nessa análise, não foram observadas diferenças estatísticas entre os explantes iniciais (0 dias), os fragmentos de folhas que não reagiram (NR), os segmentos foliares em processo de rizogênese (FL + 
$R Z$ ) ou calogênese $(F L+C L)$ e os calos primários que, na média, apresentaram cerca de 135 nmol. $\mathrm{mg}^{-1}$ de massa seca deste aminoácido. Por outro lado, constatou-se nos tecidos dos calos embriogênicos que os valores de prolina apresentaram índices próximos a $400 \mathrm{nmol} . \mathrm{mg}^{-1}$ de massa seca, concentração significativamente superior às quantificadas nos demais estádios de desenvolvimento examinados.

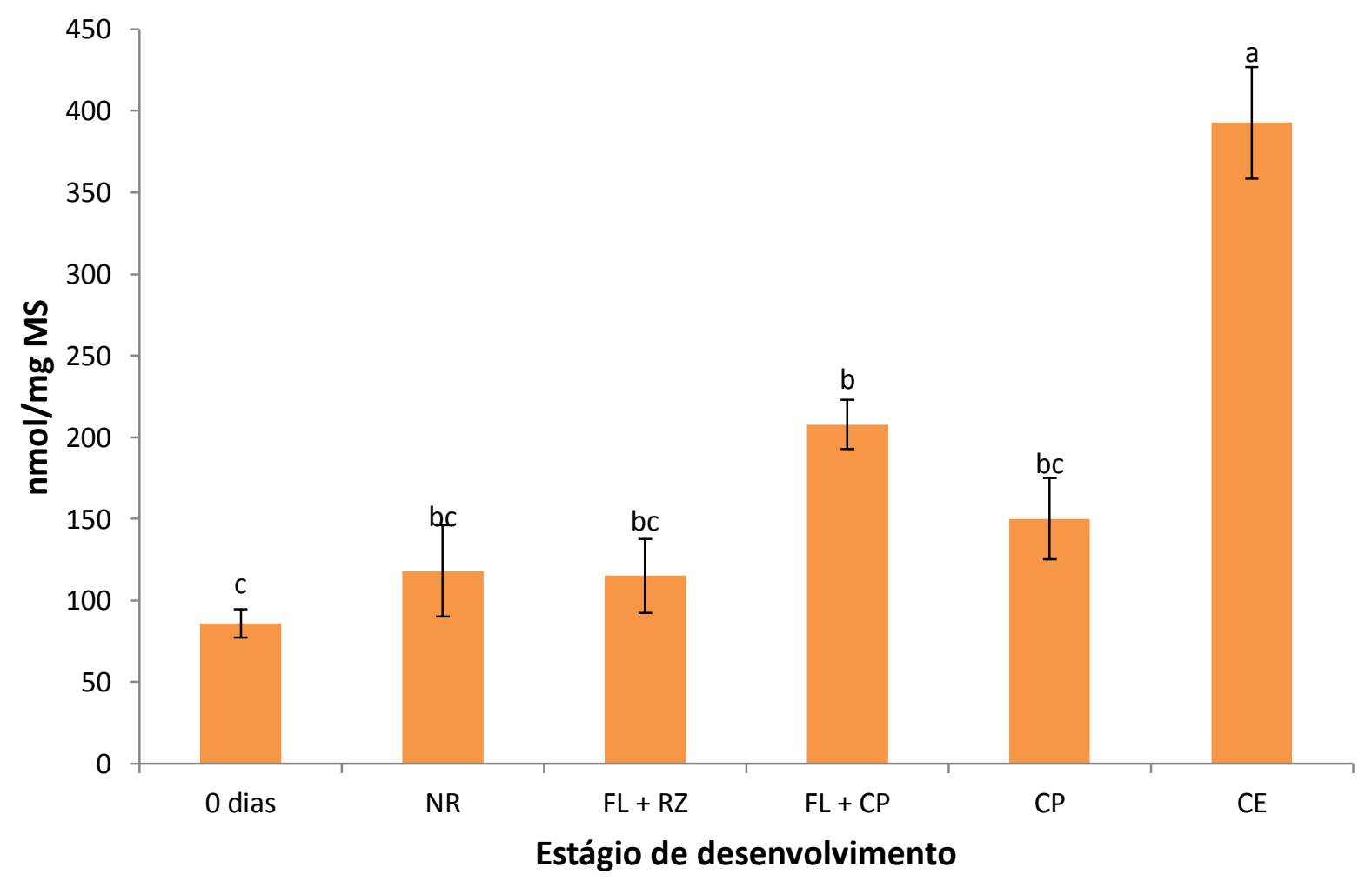

Figura 10. Teores de prolina nos estádios de desenvolvimento obtidos durante a indução da embriogênese somática de folhas imaturas de plantas adultas dendezeiro (Elaeis guineensis Jacq.). Abreviações: $N R=$ folha que não reagiu; $F L+R Z=$ folha com raiz; $\mathrm{FL}+\mathrm{CL}=$ folha com calo primário; $\mathrm{CP}=$ calo primário; $\mathrm{CE}=$ calo embriogênico. Os dados representam as médias seguidas dos erros padrões. Médias seguidas pela mesma letra não diferem estatisticamente entre si pelo teste de Tukey a $5 \%$ de probabilidade.

Tais resultados corroboram Gomes et al. (2014), no estudo do metabolismo do aminoácido prolina no transcorrer da etapa de indução da embriogênese somática de embriões zigóticos de dendezeiro, que também verificaram um aumento expressivo nos níveis deste composto concomitantemente a formação de massas meristemáticas ao longo da camada de células adjacentes ao tecido vascular (Silva et al., 2014b). Para os 
autores, esse acúmulo de prolina durante essa fase do processo de indução está, possivelmente, associado ao estresse inerente à desprogramação e reprogramação celular induzida pelas altas concentrações de auxina acrescidas aos meios de cultura.

Sen et al. (2002), Nieves et al. (2008) e Jariteh et al. (2015) também relataram ao longo do desenvolvimento embriogênico de Vigna mungo, Saccharum sp. e Juglans regia, respectivamente, elevações expressivas nas concentrações de prolina nos tecidos em estádios específicos do processo, como por exemplo, no decorrer do processo de dessecação dos embriões somáticos.

Para Lehmann et al. (2010), tais resultados se devem ao fato de que nos vegetais o teor de prolina aumenta em resposta a diferentes condições de estresse, tais como: seca, salinidade, alta luminosidade, irradiação ultravioleta, temperaturas extremas, presença de metais pesados, estresse oxidativo, infecções, entre outras adversidades.

De acordo com Verbruggen \& Hermans (2008) e Szabados \& Savouré (2010), nessas condições o acúmulo desse aminoácido é grande importância, pois atua na proteção da integridade das proteínas, melhora a atividade enzimática, exerce a função de tampão, além de promover a expressão de genes específicos, possibilitando assim, a adaptação e/ou recuperação da planta aquela determinada condição de estresse.

\subsection{Proteínas totais}

Verificou-se que os explantes iniciais ( 0 dias) e os tecidos foliares que não reagiram ao processo de indução (NR) não diferiram estatisticamente entre si quanto aos seus índices de proteínas, que no geral variaram em torno de 41,4 a $46,1 \mu \mathrm{g} \cdot \mathrm{mg}^{-1}$ de massa seca (Figura 11). Tais resultados, no entanto, foram significativamente superiores àqueles observados nos segmentos de folhas com formação de estruturas radiculares $(F L+R Z)$ e nos explantes que originaram massivos celulares ( $F L+C L$ ) que, na média, apresentaram cerca de $37,1 \mu \mathrm{g} \cdot \mathrm{mg}^{-1}$ de massa seca destes metabólitos. 


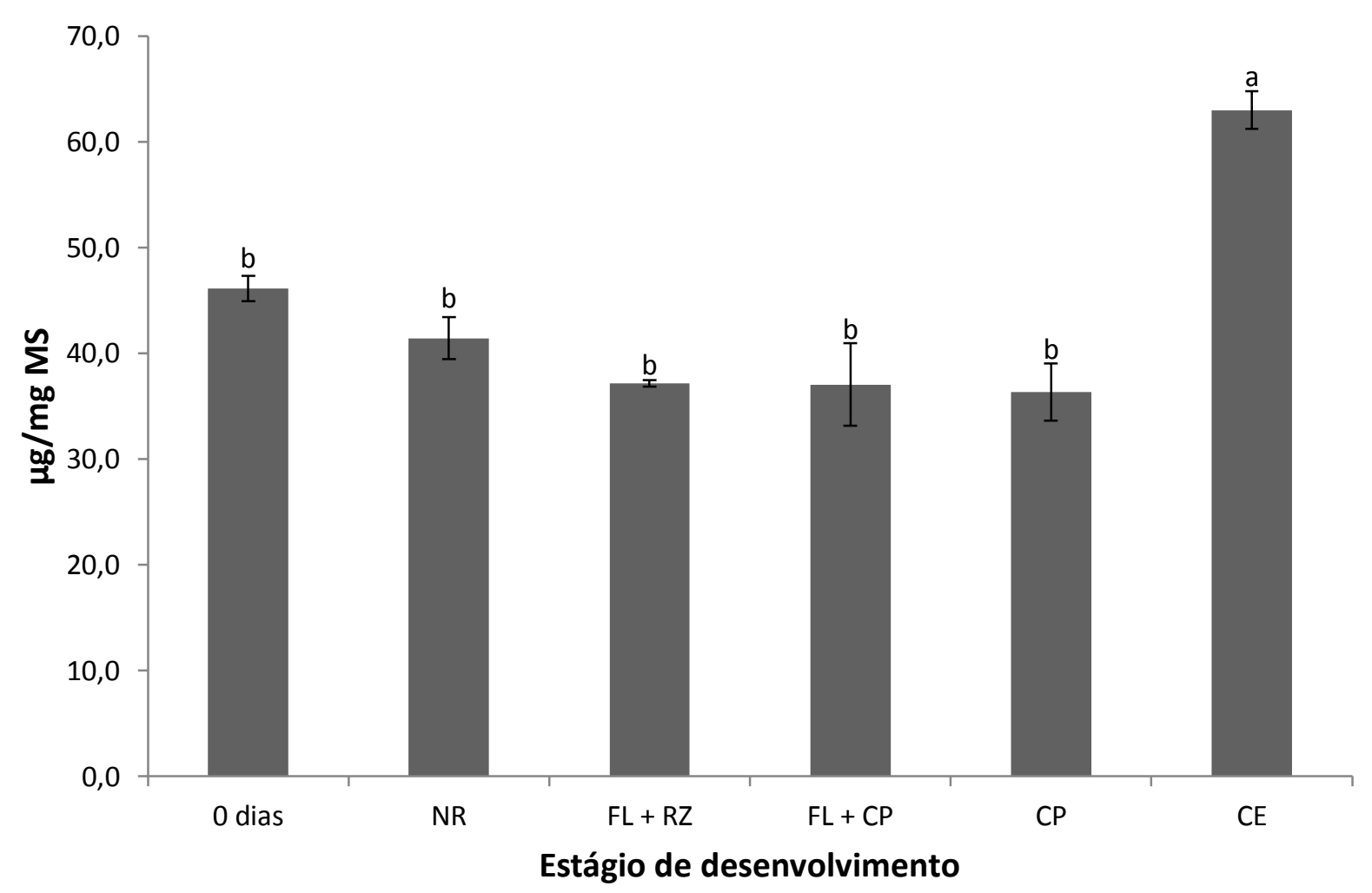

Figura 11. Teores de proteínas totais nos estádios de desenvolvimento obtidos durante a indução da embriogênese somática de folhas imaturas de plantas adultas dendezeiro (Elaeis guineensis Jacq.). Abreviações: $N R=$ folha que não reagiu; $F L+R Z=$ folha com raiz; $\mathrm{FL}+\mathrm{CL}=$ folha com calo primário; $\mathrm{CP}=$ calo primário; $\mathrm{CE}=$ calo embriogênico. Os dados representam as médias seguidas dos erros padrões. Médias seguidas pela mesma letra não diferem estatisticamente entre si pelo teste de Tukey a $5 \%$ de probabilidade.

No estudo da dinâmica das alterações fisiológicas e bioquímicas que ocorrem na embriogênese somática de Acca sellowiana, Cangahuala-Inocente et al. (2014) também observaram que na etapa de indução as concentrações de proteínas totais presentes nas culturas em desenvolvimento diminuíram em relação aos valores contidos nos tecidos dos explantes iniciais. De acordo com estes pesquisadores, essa redução nos teores destes compostos pode ser atribuída ao seu consumo a fim de ativar o metabolismo celular para o estabelecimento da competência embriogênica nestes propágulos. 
Finalmente, comparando-se os índices de proteínas totais nos diferentes tipos de calos induzidos verificou-se que, assim como constatado nas análises dos aminoácidos totais livres e dos ácidos graxos totais, os calos embriogênicos foram os cultivos que apresentaram as maiores concentrações, com cerca de $65 \mu \mathrm{g} \cdot \mathrm{mg}^{-1}$ de massa seca, valor quase duas vezes maior que o constatado nos calos primários que, em média, apresentaram aproximadamente $35 \mu \mathrm{g} \cdot \mathrm{mg}^{-1}$ de massa seca.

Os resultados são semelhantes aos descritos por Warchoł et al. (2015) durante a caracterização bioquímica da indução da embriogênese somática de Cordyline australis. No mesmo, os autores também constataram que o calo embriogênico apresentava um nível mais elevado de proteína do que os calos que não diferenciaram embriões somáticos.

Kumar \& Kumari (2011), ao estudar os fatores que afetam a embriogênese somática de Carthamus tinctorius em nível morfológico e bioquímico, também observaram que nos calos secundários da espécie houve um aumento significativo dos teores de proteínas, que neste estádio de desenvolvimento foi em média $21 \%$ superior ao observado nos calos primários.

Tais fatos também encontram-se de acordo com Fehér et al. (2003), que afirmam que a aquisição da competência embriogênica pelas células somáticas, realizada por meio de sua desdiferenciação e reprogramação, envolve a expressão de uma grande quantidade de proteínas.

Segundo Silva et al. (2014a), nessa etapa da embriogênese somática de Elaeis guineensis são expressos diferentes grupos de proteínas, entre as quais incluem-se as proteínas envolvidas no ciclo celular, proteínas relacionadas com o acúmulo de amido, proteínas do metabolismo energético, proteínas do ciclo do nitrogênio, proteínas associadas ao processamento proteico, além daquelas expressas em condições de estresse.

\subsection{Análise do Perfil Metabólico}

Os resultados referentes à análise do perfil metabólico dos estádios de desenvolvimento embriogênico são apresentados na Figura 12. Avaliando o metabolismo dos aminoácidos, observa-se que que, em sua maioria, as folhas do tratamento controle (zero dias de cultivo) apresentaram maiores concentrações que as 
folhas com calos e e as folhas que não reagiram, apresentaram taxas ainda menores do que as Folhas com Calo. A elevada concentração de aminoácidos por ocasião da inoculação é possivelmente devido ao conteúdo endógeno do explante, o qual vai se exaurindo durante o processo de formação do calo primário. A partir desse período, os teores de aminoácido se elevam indicando que nesse intervalo ocorre à absorção dos aminoácidos adicionados ao meio de cultura que foram utilizados durante o desenvolvimento do calo.

De maneira geral, as maiores taxas de aminoácidos foram verificadas nos calos embriogênicos quando comparados com os calos primários. Os resultados corroboram os dados apresentados na seção 3.4. previamente descrita (Aminoácidos Livres), onde são verificadas que maiores taxas de aminoácidos em calos embriogênicos podem estar associadas à síntese de proteínas responsáveis pelo crescimento e desenvolvimento de tecidos vegetais com elevada atividade metabólica.

Segundo Wetherell \& Dougal (1976), diferenças nas concentrações de aminoácidos endógenos têm-se mostrado efetivas na síntese de proteínas durante os processos morfogênicos, como a germinação de sementes, a organogênese e a embriogênese. Kamada \& Harada (1984) reportaram que a quantidade de aminoácidos totais aumentava rapidamente durante a proliferação de células nos estágios iniciais da embriogênese somática em culturas de cenoura, sugerindo o papel fundamental dos aminoácidos neste processo de desenvolvimento. Entretanto, o papel real dos aminoácidos no processo embriogênico continua indefinido e o metabolismo dos aminoácidos ainda não foi inteiramente caracterizado.

No presente trabalho, enquanto nos dias iniciais de cultivo os teores de aminoácidos eram altos, os de carboidratos solúveis foram baixos. Esses resultados podem significar que os carboidratos solúveis foram consumidos durante o processo de redução do nitrogênio para a formação de compostos aminados como os aminoácidos. Para Mesquita et al. (2009), o aumento nos teores de aminoácidos pode ser devido a uma absorção considerável do nitrogênio do meio de cultura. Segundo George et al. (1988), a presença de amônio no meio de cultura resulta no aumento da síntese de aminoácidos e proteínas, os quais, geralmente, são produzidos utilizando energia liberada no catabolismo dos carboidratos.

Por outro lado, é provável que no presente trabalho, tais resultados estejam também associados com a suplementação dos meios de indução e multiplicação com 
quantidades significativas de compostos nitrogenados, como a glutamina, a caseína hidrolisada, a cisteína e a asparagina que, favoreceram a síntese e o acúmulo de aminoácidos livres.

Avaliando o metabolismo dos ácidos orgânicos presente na Figura 12, observase que, de maneira geral, o citrato e o succinato apresentaram comportamentos semelhantes, onde as folhas do tratamento controle (folhas com zero dias de cultivo) apresentaram maiores concentrações que as folhas com calos e aquelas que não reagiram. Já o malato foi observado em concentração mais elevada nas folhas com calo. Citrato e succinato apresentaram um aumento gradativo no decorrer das etapas de indução, apresentando os maiores níveis nos calos embriogênicos. Diferentemente desses ácidos orgânicos, o malato apresentou um aumento gradual até a formação dos calos primários, apresentando uma redução considerável nos calos embriogênicos.

Eastmond \& Graham (2001) verificam que após a ação da Acetil-CoA são originados de ácidos orgânicos, dentre os quais, as variações nas quantidades de malato estão relacionadas com o transporte do Malato para fora da mitocôndria e a formação de Oxaloacetato no citosol. 


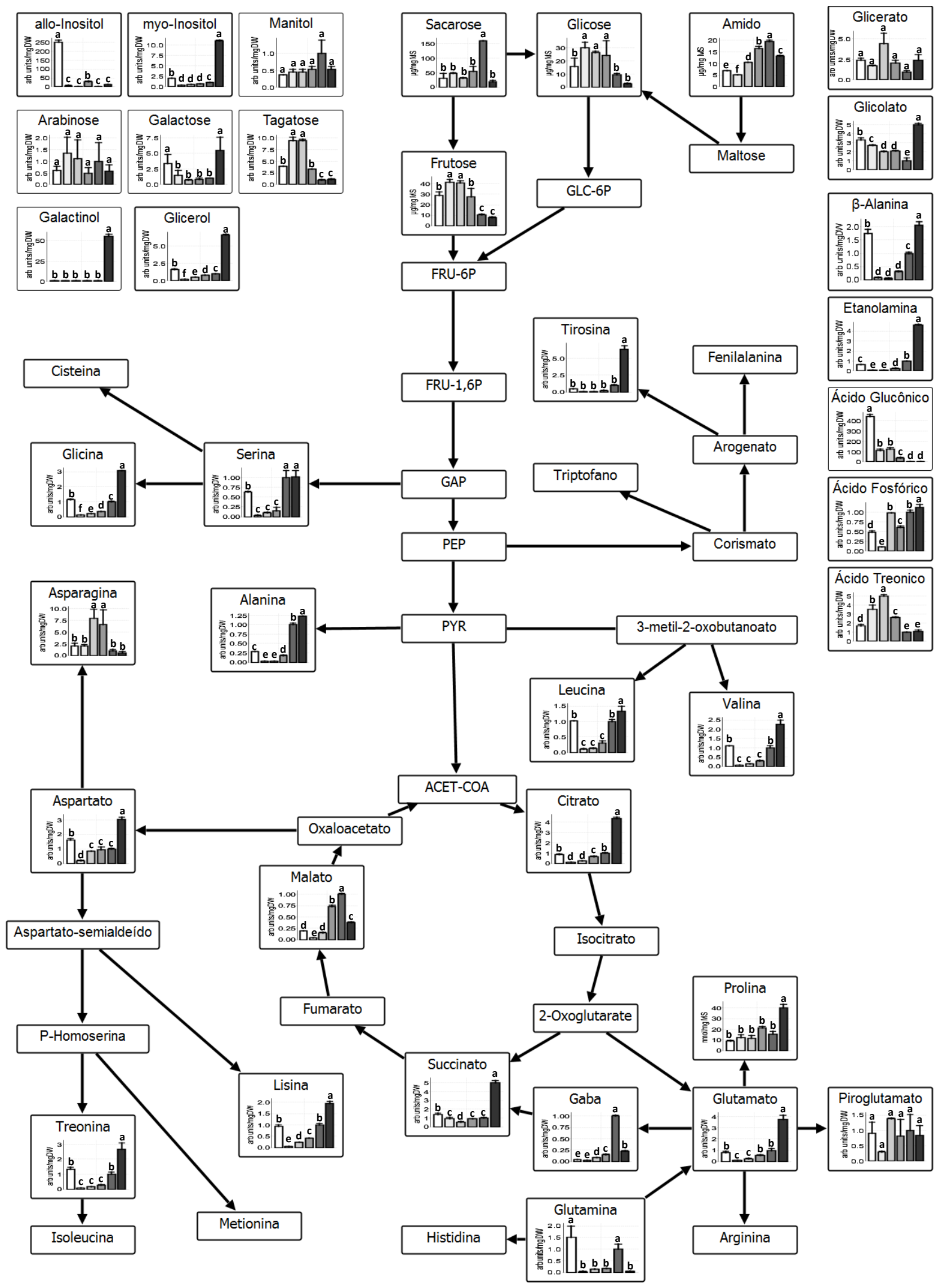

$\begin{array}{lll}\text { O FOLHAODIAS } & \text { FOLHA+RAIZ } & \text { CALO PRIMÁRIO } \\ \text { FOLHAQUENÃO REAGIU } & \bigcirc \text { FOLHA+CALO } & \text { CALOEMBRIOGÉNICO }\end{array}$

$\begin{array}{lll}\text { OFOLHAODIAS } & \bigcirc \text { FOLHA+RAIZ } & \text { CALO PRIMÁRIO } \\ \text { FOLHAQUENÃO REAGIU } & \bigcirc \text { FOLHA+CALO } & \text { CALO EMBRIOGÉNICO }\end{array}$

Figura 12. Perfil metabólico das etapas evolvidas na indução de calos a partir de folhas jovens de dendezeiro (Elaeis guineensis Jacq.). Médias seguidas pela mesma letra não diferem estatisticamente entre si pelo teste de Tukey a 5\% de probabilidade. Cada nó 
da figura corresponde a um composto presente no fluxo metabólico. Os nós que não exibem o gráfico com as dosagens apresentadas, representam os compostos que não tiveram níveis suficientes de detecção pelo equipamento. Os nós com os gráficos apresentados representam, de forma resumida, uma via específica de síntese ou degradação de algum composto. Na figura não foi compreendido todo o metabolismo, somente os compostos detectados e as vias aos quais estão relacionados de forma resumida. As setas indicam apenas quais os compostos estão interligados no metabolismo, não indicando necessariamente o sentido da reação. Os dados de Glicose, Frutose, Sacarose e Amido são os mesmos encontrados na seção 3.1. AST e 3.2. Amido. 


\section{CONCLUSÕES}

Avaliando as concentrações de açúcares solúveis totais observa-se que não há diferenças significativas entre os segmentos foliares de dendezeiro que se mostraram responsivos ( $F L+C L$ ) ou não $(N R)$ ao processo de indução da embriogênese somática. No entanto, a FL $+C L$ apresenta níveis inferiores de frutose, juntamente com uma maior concentração de amido que o observado em NR. Com relação aos teores de açúcares solúveis totais e amido nos diferentes tipos de calo, verifica-se diferença considerável entre eles, onde os calos primários (CP) apresentam maiores concentrações de açúcares e amido quando comparados com os calos embriogênicos (CE), diferindo também em uma maior concentração de sacarose no CP. Com relação à concentração dos ácidos graxos, não há diferenças significativas entre FL + CL e NR. Já o balanço verificado nos calos é oposto ao observado em relação aos açúcares e amido, pois, nesse caso, os CE apresentam taxas superiores de ácidos graxos. Se referindo aos teores dos ácidos graxos que constituem os compostos lipídicos verificase que, de forma geral, os lipídios que compõem o corpo dos cultivos em desenvolvimento são compostos em sua maior parte pelo ácido palmítico e pelo ácido linoléico, que juntos possuem uma abundância relativa média de aproximadamente $80 \%$. Os teores de aminoácidos totais livres apresentam um acúmulo gradativo durante as etapas da indução, onde os explantes controle (folhas com zero dias de cultivo) e FL + CL não diferem estatisticamente e apresentam concentrações superiores às observadas em NR e FL $+R Z$, com os teores aumentando em $C P$ e sendo ainda maiores em CE. Em todo o cultivo, apenas os CE apresentam maiores concentração de prolina, enquanto os demais estádios de desenvolvimento não diferem significativamente entre si. Em relação à concentração de proteínas totais, folhas do tratamento controle e NR apresentam níveis intermediários, com taxas reduzindo até a formação de $\mathrm{CP}$, aumentando nos CEs. 


\section{REFERÊNCIAS BIBLIOGRÁFICAS}

ALY, M. A., AMER, E. A., AL-ZAYADNEH, W. A., \& ELDIN, A. E. N. Growth regulators influence the fatty acid profiles of in vitro induced jojoba somatic embryos. Plant Cell, Tissue and Organ Culture, v.93, p.107-114, 2008.

AMARAL, L. I. V.; COSTA, P. M. F.; AIDAR, M. P. M.; GASPAR, M. BUCKERIDGE, M. $S$. Novo método enzimático rápido e sensível de extração e dosagem de amido em materiais vegetais. Hoehnea, v.34, p.425-431, 2007.

BAUD, S.; BOUTIN, J. P.; MIQUEL, M.; LEPINIEC, L.; ROCHAT, C. An integrated overview of seed development in Arabidopsis thaliana ecotype WS. Plant Physiology and Biochemestry, p.151-160, 2002.

BLANCKAERT, A.; BELINGHERI, L.; VASSEUR, J.; HILBERT, J.L. Changes in lipid composition during somatic embryogenesis in leaves of Cichorium. Plant Science, v.157, p.165-172, 2000.

BRADFORD, M. M. A rapid sensitive method for quantitation of microgram quantities of protein utilizing the principle of protein-dye binding. Analytical Biochemistry, v.72, p.248-254, 1956.

CANGAHUALA-INOCENTE, G. C.; SILVEIRA, V.; CAPRESTANO, C. A.; FLOH, E. I.; GUERRA, M. P. Dynamics of physiological and biochemical changes during somatic embryogenesis of Acca sellowiana. In Vitro Cellular and Developmental Biology Plant, v.50, p.166-175, 2014.

Corley R, Tinker P.The Oil Palm.4 Ed. Oxford.Blackwell Science; 2003.

CUNHA, A. C.; FERNANDES-FERREIRA, M. Ontogenic variations in free and esterified fatty acids during somatic embryogenesis of flax (Linum usitatissimum L.). Plant Science, v.164, p.863-872, 2003.

DUBOIS, M.; GILLES, K. A.; HAMILTON, J. K.; REBERS, P. A.; SMITH, F. Colorimetric method for the determination of sugars and related substances. Analytical Chemistry, v.28, p.350-356, 1956.

DURAND-GASSELIN, T.; GUEN, V.; KONAN, K.; DUVAL, Y. Oil palm (Elaeis guineensis Jacq.) plantations in Ivory Coast obtained through in vitro culture. First results. Oléagineux, v.45, p.1-11, 1990.

DUSSERT, S.; GUERIN, C.; ANDERSSON, M.; JOËT, T.; TRANBARGER, T. J.; PIZOT, M.; SARAH, G.; OMORE, A.; DURAND-GASSELIN, T.; MORCILLO, F. Comparative transcriptome analysis of three oil palm fruit and seed tissues that differ in oil content and fatty acid composition. Plant Physiology, v.162, p.1337-1358, 2013.

EASTMOND, P. J., \& GRAHAM, I. A. Re-examining the role of the glyoxylate cycle in oilseeds. Trends in plant science, v.6), p.72-78, 2001. 
FEHÉR, A.; PASTERNAK, T. P.; DUDITS, D. Transition of somatic plant cells to an embryogenic state. Plant Cell, Tissue and Organ Culture, v.74, p.201-228, 2003.

FIEHN, O.; KOPKA, J.; DÖRMANN, P.; ALTMANN, T.; TRETHEWEY, R. N.; WILLMITZER, L. Metabolite profiling for plant functional genomics. Nature biotechnology, v.18, p.1157-1161, 2000.

FRITSCHE-NETO, R., \& DOVALE, J. C. Breeding for Stress-Tolerance or ResourceUse Efficiency?. In Plant Breeding for Abiotic Stress Tolerance, Springer, Berlin Heidelberg, p.13-19, 2012.

GANTAIT, S.; SINNIAH, U. R.; SURANTHRAN, P.; PALANYANDY, S. R.; SUBRAMANIAM, S. Improved cryopreservation of oil palm (Elaeis guineensis Jacq.) polyembryoids using droplet vitrification approach and assessment of genetic fidelity. Protoplasma, v.252, p.89-101, 2015.

GEORGE, E.F. et al. Plant culture media: commentary and analysis. England: Exegetics, 1988.

GOMES, H. T.; BARTOS, P. M. C.; SILVA, C. O.; AMARAL, L. I. V.; SCHERWINSKIPEREIRA, J.E. Comparative biochemical profiling during the stages of acquisition and development of somatic embryogenesis in African oil palm (Elaeis guineensis Jacq.). Plant Growth Regulation, v.74, p.199-208, 2014.

GRIGOVÁ, M.; KUBEŃ, M.; DRÁŽNÁ, N.; ŘEZANKA, T.; \& LIPAVSKÁ, H. Storage lipid dynamics in somatic embryos of Norway spruce (Picea abies): histochemical and quantitative analyses. Tree Physiology, v.27, p.1533-1540, 2007.

GUERRA, M. P.; HANDRO, W. Somatic embryogenesis and plant regeneration in embryo cultures of Euterpe edulis Mart. (Palmae). Plant Cell Report, v.7, p.550-552, 1998.

HANSEN, S.B.; PADFIELD, R.; SYAYUTI, K.; EVERS, S.; ZAKARIAH, Z.; MASTURA, $S$. Trends in global palm oil sustainability research. Journal of Cleaner Production, v.100, p.140-149, 2015.

IRAQUI, D.; TREMBLAY, F. M.; Analysis of carbohydrate metabolism enzymes and cellular contents of sugars and proteins during spruce somatic embryogenesis suggests a regulatory role of exogenous sucrose in embryo development. Journal of Experimental Botany, v.52, p.301-2311, 2001.

JALIGOT, E.; ADLER, S.; DEBLADIS, É.; BEULÉ, T.; RICHAUD, F.; Epigenetic imbalance and the floral developmental abnormality of the in vitro regenerated oil palm Elaeis guineensis. Annals of Botany, v.108, p.1453-1462, 2011.

JARITEH, M.; EBRAHIMZADEH, H.; NIKNAM, V.; MIRMASOUMI, M.; VAHDATI, K. Developmental changes of protein, proline and some antioxidant enzymes activities in somatic and zygotic embryos of Persian walnut (Juglans regia L.). Plant Cell, Tissue and Organ Culture, v.122, p.101-115, 2015. 
KAMADA, H., \& HARADA, $H$. Changes in endogenous amino acid compositions during somatic embryogenesis in Daucus carota L. Plant and cell physiology, v.25, p.27-38, 1984.

KUMAR, S. P.; KUMARI, B. D. R. Factors Affecting on Somatic Embryogenesis of Safflower (Carthamus tinctorius L) at Morphological and Biochemical Levels. World Journal of Agricultural Sciences, v.7, p.197-205, 2011.

LAURENS, L. M.; QUINN, M.; VAN WYCHEN, S.; TEMPLETON, D. W.; WOLFRUM, E. $\mathrm{J}$. Accurate and reliable quantification of total microalgal fuel potential as fatty acid methyl esters by in situ transesterification. Analytical and Bioanalytical Chemistry, DOI 10.1007/s00216-012-5814-0, 2012.

LEDO, A. S.; LAMEIRA, O. A.; BENBADIS, A. K.; MENEZES, I. C. de; OLIVEIRA, M. do S. P. de; FILHO, S. M. Embriogênese somática em embriões zigóticos de Euterpe oleracea Mart. Revista Brasileira Fruticultura, v.24, p.3, 2002.

LEHMANN, S.; FUNCK, D.; SZABADOS, L.; RENTSCH, D. Proline metabolism and transport in plant development. Amino acids, v.39, p.949-962, 2010.

MA, Z., MARSOLAIS, F., BERNARDS, M. A., SUMARAH, M. W., BYKOVA, N. V., \& IGAMBERDIEV, A. U. Glyoxylate cycle and metabolism of organic acids in the scutellum of barley seeds during germination. Plant Science, v.248, p.37-44, 2016.

MARTIN, A. B.; CUADRADO, Y.; GUERRA, H.; GALLEGO, P.; HITA, O.; MARTIN, L.; DORADO, A.; VILLALOBOS, N. Differences in the contents of total sugars, starch and sucrose in embryogenic and non-embryogenic calli from Medicago arborea L. Plant Science, v.154, p.143-151, 2000.

MESQUITA, A.C. et al. Análises bioquímicas de calos obtidos de segmentos foliares de lechieira (Litchi chinesnsis Sonn.). Magistra, Cruz das Almas, v.14, n.1, p.1-6, 2002.

MUKHERJEE, I.; SOVACOOL, B.K. Palm oil-based biofuels and sustainability in southeast Asia: A review of Indonesia, Malaysia, and Thailand. Renewable and Sustainable Energy Reviews, v.37, p.1-12, 2014.

NAIK, P. M., \& AL-KHAYRI, J. M. Somatic Embryogenesis of Date Palm (Phoenix dactylifera L.) Through Cell Suspension Culture. Protocols for In Vitro Cultures and Secondary Metabolite Analysis of Aromatic and Medicinal Plants, v.2, p.357-366, 2016.

NIEVES, N.; SAGARRA, F.; GONZÁLEZ, R.; LEZCANO, Y.; CID, M.; BLANCO, M. A.; CASTILLO, R. Effect of exogenous arginine on sugarcane (Saccharum sp.) somatic embryogenesis, free polyamines and the contents of the soluble proteins and praline.

Plant Cell, Tissue and Organ Culture, v.95, p.313-320, 2008.

ORTIZ-LOPEZ, A., CHANG, H. C., \& BUSH, D. R. Amino acid transporters in plants. Biochimica et Biophysica Acta (BBA)-Biomembranes, v.1465, p.275-280, 2000. 
PESCADOR, R.; KERBAUY, G. B.; KRAUS, J. E.; FERREIRA, W. M.; GUERRA, M. P.; FIGUEIREDO-RIBEIRO, R. de C. Changes in soluble carbohydrates and starch amounts during somatic and zygotic embryogenesis of Acca sellowiana (Myrtaceae). In Vitro Cellular and Developmental Biology - Plant, v.44, p.289-299, 2008.

PESCADOR, R.; KERBAUY, G. B.; SANTOS, D. Y. A. C.; DAL VESCO, L. L.; FRAGA, H. P. F.; GUERRA, M. P. Comparative study of reserve lipid accumulation during somatic and zygotic Acca sellowiana (O. Berg.) Burret embryogenesis. Acta Physiologiae Plantarum, v.34, p.771-778, 2012.

REIDIBOYM-TALLEUX, L.; MARCH, G. D. Lipid and fatty acid composition in non-embryogenic calli and embryogenic tissues in wild cherry (Prunus avium). Physiologia Plantarum, v.105, p.513-520, 1999.

REY L, GÓMEZ P, AYALA I, DELGADO W, ROCHA P. Colecciones genéticas de palma de aceite Elaeis guineensis (Jacq.) y Elaeis oleifera (H.B.K.) de Cenipalma: Características de importancia para el sector palmicultor. Palmas. v.25, p.39-48, 2004.

RIVAL, A.; ABERLENC, F.; MORCILLO, F.; TREGEAR, J.; VERDEIL, J. L.; DUVAL, Y. Scaling-up in vitro clonal propagation through somatic embryogenesis : the case of oil palm (Elaeis guineensis Jacq.). Plant Tissue Culture and Biotechnology, v.3, p.7482, 1997.

ROCHA P, PRADA F, REY L, AYALA I. Caracterización bioquímica parcial de la colección de Elaeis oleifera de Cenipalma proveniente de la Amazonía colombiana. Palmas, v.27, 35-44, 2006.

SCHERWINSKI-PEREIRA, J. E.; GUEDES, R. S.; SILVA, T. L.; FERMINO, J. R. P. C. P.; COSTA, F. H. S. Somatic embryogenesis and plant regeneration from oil palm thin cell layer. In Vitro Cellular and Development Biology - Plant, v.46, p.378-385, 2010.

SEN, J.; KALIA, S.; GUHA-MUKHERJEE, S. Level of endogenous free amino acids during various stages of culture of Vigna mungo (L.) Hepper-somatics embryogenesis, organogenesis and plant regeneration. Current Science, v.82, p.429-433, 2002.

SILVA, R. C.; LUIS, Z. G.; SCHERWINSKI-PEREIRA, J. E. The histodifferentiation events involved during the acquisition and development of somatic embryogenesis in oil palm (Elaeis guineensis Jacq.). Plant Growth Regulation, v.72, p.67-80, 2014.

SILVA, R. C.; CARMO, L. S. C.; LUIS, Z. G. L.; SILVA, L. P.; SCHERWINSKIPEREIRA, J. E.; MEHTA, A. Proteomic identification of differentially expressed proteins during the acquisition of somatic embryogenesis in oil palm (Elaeis guineensis Jacq.). Journal of Proteomics, v.104, p.112-127, 2014.

STEINMACHER, D. A.; KROHN, N. G.; DANTAS, A. C. M.; STEFENON, V. M.; CLEMENT, C. R.; GUERRA, M. P. Somatic embryogenesis in peach palm using the thin cell layer technique: induction, morpho-histological aspects and AFLP analysis of somaclonal variation. Annals of Botany, v.100, p.1-11, 2007. 
SZABADOS, L.; SAVOURÉ, A. Proline: a multifunctional amino acid. Trends in Plant Science, v.15, p.89-97, 2010.

TORRES M, REY L, GELVES F, SANTACRUZ L. Evaluación del comportamiento de los híbridos interespecíficos Elaeis oleifera x Elaeis guineensis en la plantación Guaicaramo S.A. Palmas. v.25, p.351-357, 2004.

TORRES G, SARRIA G, VARON F, COFFEY M, ELLIOT M, MARTINEZ G. First report of bud rot caused by Phytophthora palmivora on African oil palm in Colombia. Plant Disease. v.94, p.1163, 2010.

TURNHAM, E.; NORTHCOTE, D. H. The incorporation of [1-14C] acetate into lipids during embryogenesis in oil palm tissue cultures. Phytochemistry, v.23, p.35-39, 1984.

VERBRUGGeN, N.; HERMANS, C. Proline accumulation in plants: a review. Amino Acids, v.35, p.753-759, 2008.

WARCHOL, M.; SKRZYPEK, E.; KUSIBAB, T.; DUBERT, F. Induction of somatic embryogenesis and biochemical characterization of Cordyline australis (G. Forst.) Endl. Red Star"callus. Scientia Horticulturae, v.192, p.338-345, 2015.

WEBER, H.; BORISJUK, L.; WOBUS, U. Sugar important and metabolism during seed development. Trend Plant Science, v.2, p.169-174, 1997.

YEMM, E. W.; COCKING, E. C. The determination of amino acids with ninhydrin. Analyst, v.80, p.209-213, 1955.

WETHERELL, D. F., \& DOUGALL, D. K. Sources of nitrogen supporting growth and embryogenesis in cultured wild carrot tissue. Physiologia Plantarum, v.37, p.97-103, 1976. 